\title{
SIMULATION OF GROUND-WATER FLOW IN THE COASTAL PLAIN AQUIFER SYSTEM OF NORTH CAROLINA
}

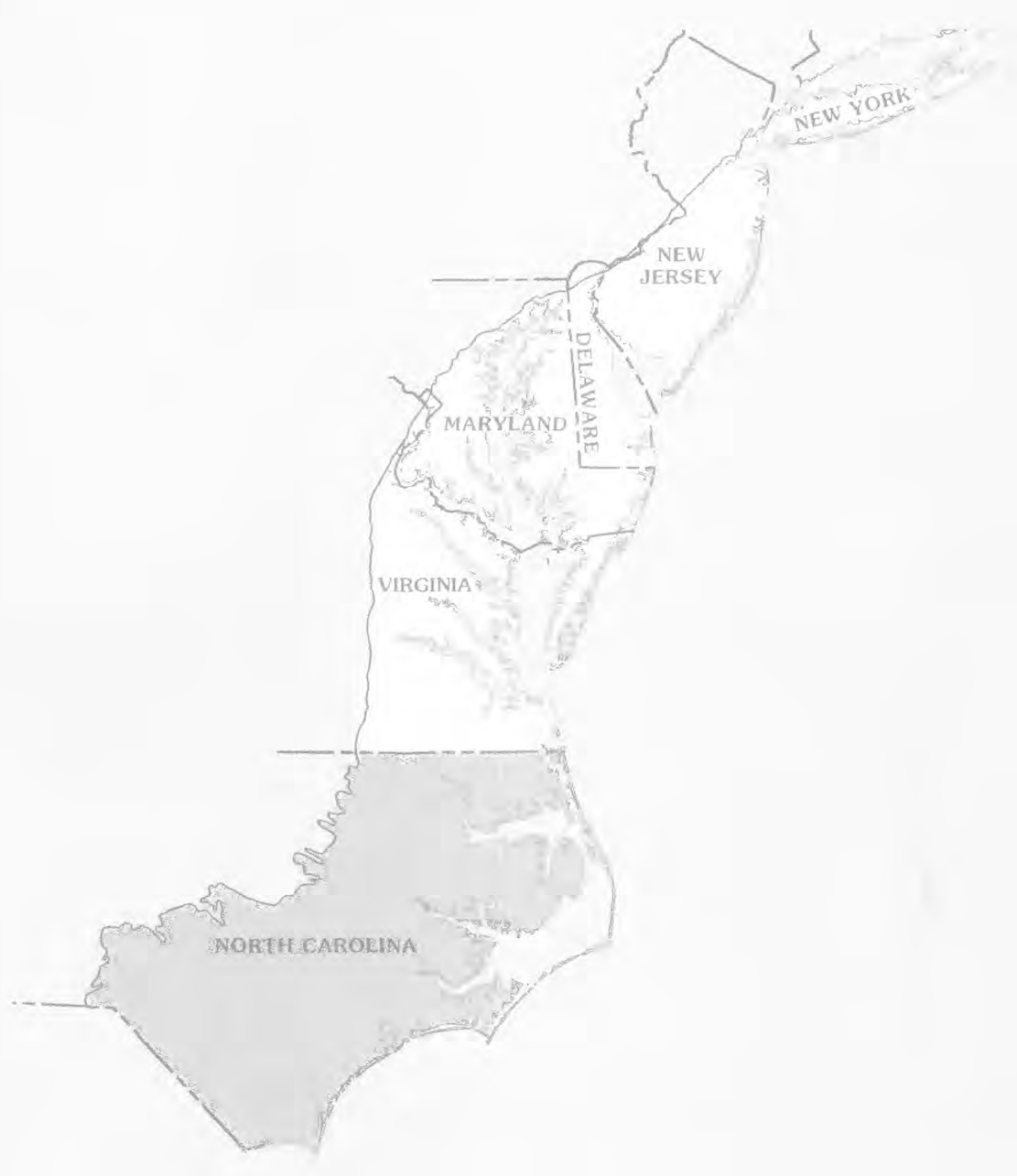




\section{AVAILABILITY OF BOOKS AND MAPS OF THE U.S. GEOLOGICAL SURVEY}

Instructions on ordering publications of the U.S. Geological Survey, along with prices of the last offerings, are given in the currentyear issues of the monthly catalog "New Publications of the U.S. Geological Survey." Prices of available U.S. Geological Survey publications released prior to the current year are listed in the most recent annual "Price and Availability List." Publications that may be listed in various U.S. Geological Survey catalogs (see back inside cover) but not listed in the most recent annual "Price and Availability List" may be no longer available.

Order U.S. Geological Survey publications by mail or over the counter from the offices given below.

\section{BY MAIL}

\section{Books}

Professional Papers, Bulletins, Water-Supply Papers, Techniques of Water-Resources Investigations, Circulars, publications of general interest (such as leaflets, pamphlets, booklets), single copies of Preliminary Determination of Epicenters, and some miscellaneous reports, including some of the foregoing series that have gone out of print at the Superintendent of Documents, are obtainable by mail from

U.S. Geological Survey, Information Services

Box 25286, Federal Center, Denver, CO 80225

Subscriptions to Preliminary Determination of Epicenters can be obtained ONLY from the

\section{Superintendent of Documents \\ Government Printing Office Washington, DC 20402}

(Check or money order must be payable to Superintendent of Documents.)

\section{Maps}

For maps, address mail orders to

U.S. Geological Survey, Information Services Box 25286, Federal Center, Denver, CO 80225

\section{OVER THE COUNTER}

\section{Books and Maps}

Books and maps of the U.S. Geological Survey are available over the counter at the following U.S. Geological Survey Earth Science Information Centers (ESIC's), all of which are authorized agents of the Superintendent of Documents:

- ANCHORAGE, Alaska-Rm. 101, 4230 University Dr.

- LAKEWOOD, Colorado-Federal Center, Bldg. 810

- MENLO PARK, California-Bldg. 3, Rm. 3128, 345 Middlefield Rd.

- RESTON, Virginia-USGS National Center, Rm. 1C402, 12201 Sunrise Valley Dr.

- SALT LAKE CITY, Utah-Federal Bldg., Rm. 8105, 125 South State St.

- SPOKANE, Washington-U.S. Post Office Bldg., Rm. 135, West 904 Riverside Ave.

- WASHINGTON, D.C.-Main Interior Bldg., Rm. 2650, 18th and C Sts., NW.

\section{Maps Only}

Maps may be purchased over the counter at the following U.S. Geological Survey office:

- ROLLA, Missouri-1400 Independence Rd. 
Simulation of Ground-Water Flow in the Coastal Plain Aquifer System of North Carolina

By G.L. GIESE, J.L. EIMERS, and R.W. COBLE

REGIONAL AQUIFER-SYSTEM ANALYSISNORTHERN ATLANTIC COASTAL PLAIN

U.S. GEOLOGICAL SURVEY PROFESSIONAL PAPER 1404-M

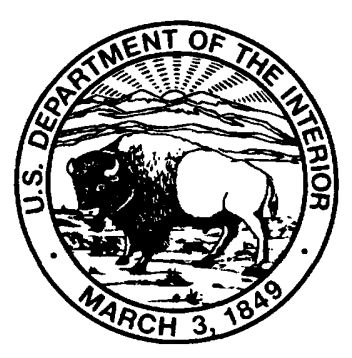




\section{U.S DEPARTMENT OF THE INTERIOR \\ BRUCE BABBITT, Secretary}

\section{U.S GEOLOGICAL SURVEY \\ Gordon P. Eaton, Director}

Any use of trade, product, or firm names in this publication is for descriptive purposes only and does not imply endorsement by the

U.S. Government.

\section{Library of Congress Cataloging in Publication Data}

Giese, G.L.

Simulation of ground-water flow in the Coastal Plain aquifer system of North Carolina / by G.L. Giese, J.L. Eimers, and R.W. Coble.

p. $\quad$ cm. - (Regional aquifer-system analysis) (U.S. Geological Survey professional paper ; 1404-M)

Includes bibliographical references.

1. Ground-water flow-North Carolina-Computer simulation. I. Eimers, Jo Leslie. II. Coble, Ronald W. (Ronald Wimmer).

III. Title. IV. Series. V. Series: U.S. Geological Survey professional paper ; 1404-M.

GB1197.7.G54 1997

$551.49^{\prime} 09756-\mathrm{dc} 20$ 


\section{FOREWORD}

\section{THE REGIONAL AQUIFER-SYSTEM ANALYSIS PROGRAM}

The Regional Aquifer-System Analysis (RASA) Program represents a systematic effort to study a number of the Nation's most important aquifer systems, which, in aggregate, underlie much of the country and which represent an important component of the Nation's total water supply. In general, the boundaries of these studies are identified by the hydrologic extent of each system and, accordingly, transcend the political subdivisions to which investigations have often arbitrarily been limited in the past. The broad objective for each study is to assemble geologic, hydrologic, and geochemical information; to analyze and develop an understanding of the system; and to develop predictive capabilities that will contribute to the effective management of the system. The use of computer simulation is an important element of the RASA studies to develop an understanding of the natural, undisturbed hydrologic system and the changes brought about in it by human activities, and to provide a means of predicting the regional effects of future pumping or other stresses.

The final interpretive results of the RASA Program are presented in a series of U.S. Geological Survey Professional Papers that describe the geology, hydrology, and geochemistry of each regional aquifer system. Each study within the RASA Program is assigned a single Professional Paper number beginning with Professional Paper 1400.

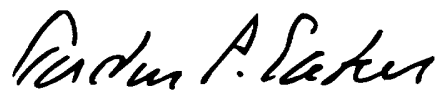

Gordon P. Eaton Director 
. 


\section{CONTENTS}

Foreword

Abstract.

Introduction.

Purpose and Scope.

Methods of Investigation.

Previous Investigations

Acknowledgments.

Conceptualization of the Aquifer System

Hydrogeologic Framework

Surficial Aquifer

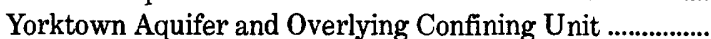

Pungo River Aquifer and Overlying Confining Unit .............

Castle Hayne Aquifer and Overlying Confining Unit.........

Beaufort Aquifer and Overlying Confining Unit

Peedee Aquifer and Overlying Confining Unit ......................

Black Creek Aquifer and Overlying Confining

$$
\text { Unit. }
$$

Upper Cape Fear Aquifer and Overlying Confining Unit .

Lower Cape Fear Aquifer and Overlying Confining Unit

Lower Cretaceous Aquifer and Overlying Confining

Unit

Simulation of Ground-Water Flow .

Equation of Ground-Water Flow

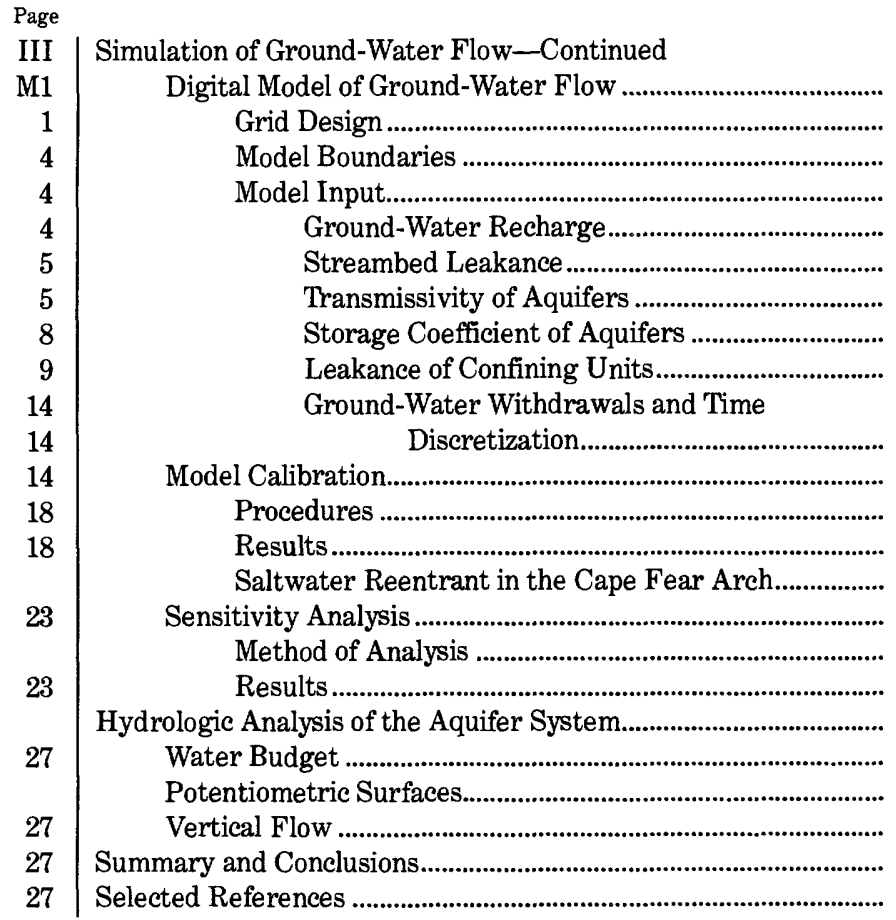

\section{ILLUSTRATIONS}

FIGURE 1. Map showing the study area of the North Carolina Coastal Plain aquifer system

2. Map showing the Northern Atlantic Coastal Plain study area.

3. Sketch showing typical annual water budget for the North Carolina Coastal Plain hydrogeologic system

4. Idealized hydrogeologic cross section showing features of the ground-water flow system.

5-9. Hydrogeologic section:

5. $A-A^{\prime}$ from Richmond County to Brunswick County

6. $B-B^{\prime}$ from Johnston County to Pamlico County

7. $C-C^{\prime}$ from Southampton County, Va., to Currituck County, N.C

8. $D-D^{\prime}$ from Brunswick County to Onslow County.

9. $D^{\prime}-D^{\prime \prime}$ from Onslow County to Chowan County.

10-21. Maps showing areal extent of the-

10. Yorktown aquifer and underlying aquifers or basement rock...

11. Pungo River aquifer and overlying aquifers

12. Castle Hayne aquifer and overlying aquifers.

13. Castle Hayne aquifer and underlying aquifers .

14. Beaufort aquifer and overlying aquifers

15. Beaufort aquifer and underlying aquifers.

16. Peedee aquifer and overlying aquifers...

17. Black Creek aquifer and overlying aquifers 
Figures 10-21. Maps showing areal extent of the-Continued

18. Upper Cape Fear aquifer and overlying aquifers.

(1)

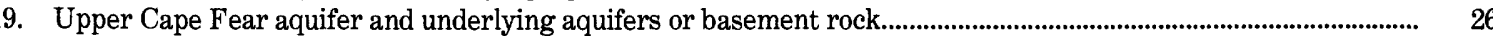

20. Lower Cape Fear aquifer and overlying aquifers ......................................................................................................... 28

21. Lower Cape Fear aquifer and underlying aquifers or basement rock ................................................................................ 29.

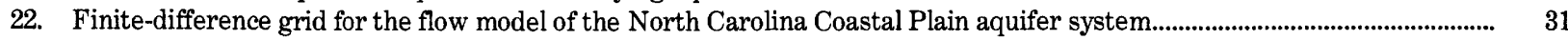

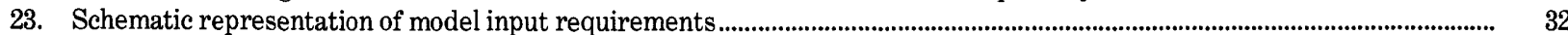

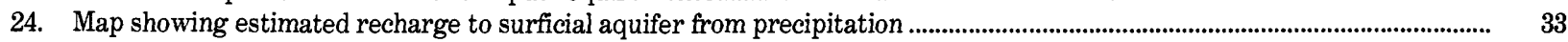

25. Map showing distribution of estimated streambed leakance ....................................................................................................................

26-34. Maps showing transmissivity used in model simulations for the-

26. Yorktown aquifer.

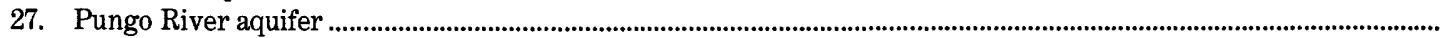

28. Castle Hayne aquifer.

29. Beaufort aquifer

30. Peedee aquifer.

31. Black Creek aquifer.

32. Upper Cape Fear aquifer

33. Lower Cape Fear aquifer

34. Lower Cretaceous aquifer

35-43. Maps showing total effective thickness of the-

35. Yorktown confining unit.

36. Pungo River confining unit.

37. Castle Hayne confining unit

38. Beaufort confining unit

39. Peedee confining unit

40. Black Creek confining unit .

41. Upper Cape Fear confining unit

42. Lower Cape Fear confining unit

43. Lower Cretaceous confining unit

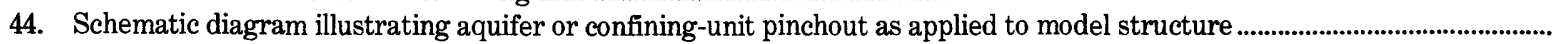

45-53. Maps showing model-derived leakance of the-

45. Yorktown confining unit.

46. Pungo River confining unit

47. Castle Hayne confining unit

48. Beaufort confining unit

49. Peedee confining unit

50. Black Creek confining unit .

51. Upper Cape Fear confining unit

52. Lower Cape Fear confining unit.

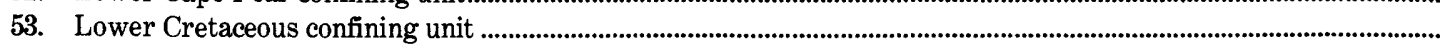

54. Graph showing ground-water pumpage in the North Carolina Coastal Plain, 1900-80, for users of more than 100,000 gallons per day

55-63. Maps showing locations of withdrawals greater than 100,000 gallons per day in 1980 , for the-

55. Surficial aquifer.

56. Yorktown aquifer

57. Pungo River aquifer

58. Castle Hayne aquifer.

59. Beaufort aquifer

60. Peedee aquifer.

61. Black Creek aquifer.

62. Upper Cape Fear aquifer

63. Lower Cape Fear aquifer

64. Diagram showing method of computing heads at off-node locations ..

65-69. Hydrographs showing observed and simulated water levels in the-

65. Yorktown and Pungo River aquifers

66. Castle Hayne aquifer at the Creswell observation well and DEHNR Arapahoe research station observation well u5

67. Beaufort and Peedee aquifers.

68. Black Creek aquifer at USGS observation wells NC-30 and NC-44

69. Upper Cape Fear and lower Cape Fear aquifers

70. Graphs showing head differences in Cretaceous sand aquifers due to changes in group 1 transmissivity, group 1

leakance, and model-wide storage coefficient

71. Map showing simulated prepumping (1900) water table for the surficial aquifer. 
FIGUREs 72-80. Maps showing simulated prepumping (1900) potentiometric surface for the-

72. Yorktown aquifer

73. Pungo River aquifer

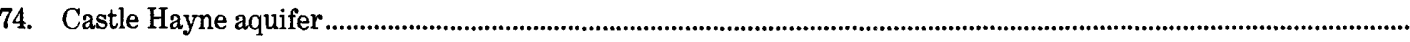

75. Beaufort aquifer

76. Peedee aquifer

77. Black Creek aquifer

78. Upper Cape Fear aquifer.

79. Lower Cape Fear aquifer

80. Lower Cretaceous aquifer

81. Map showing simulated 1980 water table for the surficial aquifer..

M91

92

93

94

95

96

97

98

99

82-90. Maps showing simulated 1980 potentiometric surface for the-

82. Yorktown aquifer

83. Pungo River aquifer

84. Castle Hayne aquifer.

85. Beaufort aquifer.

86. Peedee aquifer.

87. Black Creek aquifer

88. Upper Cape Fear aquifer.

89. Lower Cape Fear aquifer

90. Lower Cretaceous aquifer

91. Map showing simulated year 2000 water table for the surficial aquifer, assuming 3-percent annual increase in pumpage....

92-100. Maps showing simulated year 2000 potentiometric surface during 1980-2000, assuming 3-percent annual increase in pumpage, for the-

92. Yorktown aquifer

93. Pungo River aquifer

94. Castle Hayne aquifer

95. Beaufort aquifer

96. Peedee aquifer

97. Black Creek aquifer

98. Upper Cape Fear aquifer.

99. Lower Cape Fear aquifer

100. Lower Cretaceous aquifer

101-109. Maps showing net vertical flow of water, simulated for predevelopment (1900) conditions, through the-

101. Yorktown confining unit

102. Pungo River confining unit.

103. Castle Hayne confining unit.....

104. Beaufort confining unit.

105. Peedee confining unit

106. Black Creek confining unit

107. Upper Cape Fear confining unit

108. Lower Cape Fear confining unit.

109. Lower Cretaceous confining unit.

110-118. Maps showing net vertical flow of water, simulated for 1980 conditions, through the-

110. Yorktown confining unit..

111. Pungo River confining unit.

112. Castle Hayne confining unit.

113. Beaufort confining unit.

114. Peedee confining unit

115. Black Creek confining unit

116. Upper Cape Fear confining unit

117. Lower Cape Fear confining unit.

118. Lower Cretaceous confining unit. 


\section{TABLES}

TABLE 1. Hydrogeologic units for North Carolina, South Carolina, and Virginia Coastal Plain

2. North Carolina ground-water pumpage by aquifer in 1980 .

3. Ranges of vertical hydraulic conductivity of confining units for the calibrated model.

4. Summary of differences between computed and observed water levels for December 31, 1980

5. Range of perturbed values for transmissivity and leakance.

6. Range of perturbed values for storage coefficient

7. Results of sensitivity analysis...

8. Summary of model-computed water budgets for the ground-water flow system of the North Carolina Coastal Plain, 1900-2000.

\section{CONVERSION FACTORS AND VERTICAL DATUM}

\begin{tabular}{|c|c|c|}
\hline Multiply inch-pound unit & $\mathrm{By}$ & To obtain SI unit \\
\hline \multicolumn{3}{|c|}{ Length } \\
\hline $\begin{array}{r}\text { inch (in.) } \\
\text { foot (ft) } \\
\text { mile (mi) } \\
\text { foot per mile (ft/mi) }\end{array}$ & $\begin{array}{l}25.4 \\
0.3048 \\
1.609 \\
0.1894\end{array}$ & $\begin{array}{l}\text { millimeter }(\mathrm{mm}) \\
\text { meter }(\mathrm{m}) \\
\text { kilometer }(\mathrm{km}) \\
\text { meter per kilometer }(\mathrm{m} / \mathrm{km})\end{array}$ \\
\hline \multicolumn{3}{|c|}{ Area } \\
\hline $\begin{array}{r}\text { square foot }\left(\mathrm{ft}^{2}\right) \\
\text { square mile }\left(\mathrm{mi}^{2}\right) \\
\text { acre }\end{array}$ & $\begin{array}{l}0.0929 \\
2.590 \\
4,047\end{array}$ & $\begin{array}{l}\text { square meter }\left(\mathrm{m}^{2}\right) \\
\text { square kilometer }\left(\mathrm{km}^{2}\right) \\
\text { square meter }\left(\mathrm{m}^{2}\right)\end{array}$ \\
\hline \multicolumn{3}{|c|}{ Volume } \\
\hline $\begin{array}{r}\text { cubic yard }\left(\mathrm{yd}^{3}\right) \\
\text { acre-foot }\end{array}$ & $\begin{array}{l}0.7646 \\
1,233\end{array}$ & $\begin{array}{l}\text { cubic meter }\left(\mathrm{m}^{3}\right) \\
\text { cubic meter }\left(\mathrm{m}^{3}\right)\end{array}$ \\
\hline \multicolumn{3}{|c|}{ Flow } \\
\hline $\begin{array}{r}\text { cubic foot per second }\left(\mathrm{ft}^{3} / \mathrm{s}\right) \\
\text { cubic foot per second per square mile } \\
{\left[\left(\mathrm{ft}^{3} / \mathrm{s}\right) / \mathrm{mi}^{2}\right]} \\
\text { gallon per day }(\mathrm{gal} / \mathrm{d}) \\
\text { million gallons per day }(\mathrm{Mgal} / \mathrm{d})\end{array}$ & $\begin{array}{l}0.02832 \\
0.01093 \\
\\
3.785 \\
0.04381\end{array}$ & $\begin{array}{l}\text { cubic meter per second }\left(\mathrm{m}^{3} / \mathrm{s}\right) \\
\text { cubic meter per second per square } \\
\text { kilometer }\left[\left(\mathrm{m}^{3} / \mathrm{s}\right) / \mathrm{km}^{2}\right] \\
\text { liter per day }(\mathrm{L} / \mathrm{d}) \\
\text { cubic meter per second }\left(\mathrm{m}^{3} / \mathrm{s}\right)\end{array}$ \\
\hline \multicolumn{3}{|c|}{ Velocity } \\
\hline $\begin{array}{l}\text { foot per second }(\mathrm{ft} / \mathrm{s}) \\
\text { mile per hour }(\mathrm{mi} / \mathrm{hr})\end{array}$ & $\begin{array}{l}0.3048 \\
1.609\end{array}$ & $\begin{array}{l}\text { meter per second }(\mathrm{m} / \mathrm{s}) \\
\text { kilometer per hour }(\mathrm{km} / \mathrm{hr})\end{array}$ \\
\hline \multicolumn{3}{|c|}{ Mass } \\
\hline $\begin{array}{l}\text { pound (lb avoirdupois) } \\
\text { ton (short, } 2,000 \mathrm{lbs} \text { ) }\end{array}$ & $\begin{array}{l}0.4536 \\
0.9072\end{array}$ & $\begin{array}{l}\text { kilogram }(\mathrm{kg}) \\
\text { metric ton }\end{array}$ \\
\hline
\end{tabular}

Sea level: In this report, "sea level" refers to the National Geodetic Vertical Datum of 1929 (NGVD of 1929)—a geodetic datum derived from a general adjustment of the first-order level nets of both the United States and Canada, formerly called Sea Level Datum of 1929. 


\title{
SIMULATION OF GROUND-WATER FLOW IN THE COASTAL PLAIN AQUIFER SYSTEM OF NORTH CAROLINA
}

\author{
By G.L. Giese, J.L. Eimers, and R.W. CoBle
}

\begin{abstract}
A three-dimensional finite-difference digital model was used to simulate ground-water flow in the 25,000 -square-mile aquifer system of the North Carolina Coastal Plain. The model was developed from a hydrogeologic framework that is based on an alternating sequence of 10 aquifers and 9 confining units, which make up a seaward-thickening wedge of sediments that form the Coastal Plain aquifer system in the State of North Carolina.

The model was calibrated by comparing observed and simulated water levels. The model calibration was achieved by adjusting model parameters, primarily leakance of confining units and transmissivity of aquifers, until differences between observed and simulated water levels were within acceptable limits, generally within 15 feet. The maximum transmissivity of an individual aquifer in the calibrated model is 200,000 feet squared per day in a part of the Castle Hayne aquifer, which consists predominantly of limestone. The maximum value for simulated vertical hydraulic conductivity in a confining unit was 2.5 feet per day, in a part of the confining unit overlying the upper Cape Fear aquifer. The minimum value was $4.1 \times 10^{-6}$ feet per day, in part of the confining unit overlying the lower Cape Fear aquifer. Analysis indicated the model is highly sensitive to changes in transmissivity and leakance near pumping centers; away from pumping centers, the model is only slightly sensitive to changes in transmissivity but is moderately sensitive to changes in leakance.

Recharge from precipitation to the surficial aquifer ranges from about 12 inches per year in areas having clay at the surface to about 20 inches per year in areas having sand at the surface. Most of this recharge moves laterally to streams, and only about 1 inch per year moves downward to the confined parts of the aquifer system. Under predevelopment conditions, the confined aquifers were generally recharged in updip interstream areas and discharged through streambeds and in downdip coastward areas. Hydrologic analysis of the flow system using the calibrated model indicated that, because of groundwater withdrawals, areas of ground-water recharge have expanded and encroached upon some major stream valleys and into coastal areas. Simulations of pumping conditions indicate that by 1980 large parts of the former coastal discharge areas had become areas of potential or actual recharge.

Declines of ground-water level, which are the result of water taken from storage, are extensive in some areas and minimal in others. Hydraulic head declines of more than 135 feet have occurred in the northern Coastal Plain since 1940 primarily due to withdrawals in the Franklin area in Virginia. Declines of ground-water levels greater than 110 feet have occurred in aquifers in the central Coastal Plain due to combined effects of pumpage for public and industrial water supplies.
\end{abstract}

Water-level declines exceeding 100 feet have occurred in the Beaufort County area because of withdrawals for a mining operation and water supplies for a chemical plant. Head declines have been less than 10 feet in the shallow surficial and Yorktown aquifers and in the updip parts of the major confined aquifers distant from areas of major withdrawals. In 1980 , contribution from aquifer storage was 14 cubic feet per second, which is about 4.8 percent of pumpage and about 0.05 percent of ground-water recharge.

A water-budget analysis using the model simulations indicates that much of the water removed from the ground-water system by pumping ultimately is made up by a reduction in water leaving the aquifer system, which discharges to streams as base flow. The reduction in stream base flow was 294 cubic feet per second in 1980 and represents about 1.1 percent of the ground-water recharge. The net reduction to streamflow is not large, however, because most pumped ground water is eventually discharged to streams. In places, such as at rock quarries in Onslow and Craven Counties, water is lost from streams to recharge the water-table aquifer. In simulations for the period 19802000 , assuming a 3-percent increase in pumpage per year since 1980 , such induced infiltration increased about sevenfold from about 6 to 42 cubic feet per second.

\section{INTRODUCTION}

The North Carolina Coastal Plain (fig. 1) covers an area of 25,000 square miles $\left(\mathrm{mi}^{2}\right)$ in the eastern part of the State. This area includes about 47 percent of the State and encompasses all or parts of 47 counties.

The western boundary of the study area coincides roughly with the boundary between Fenneman's (1938) Coastal Plain and Piedmont Province and is delineated by the Fall Line. The northern and southern boundaries coincide with the Virginia and South Carolina borders, respectively. The eastern boundary, though not shown in figure 1, is defined as the seaward limit of ground water that has a dissolved chloride concentration of 10,000 milligrams per liter $(\mathrm{mg} / \mathrm{L})$.

The North Carolina Coastal Plain is an eastward-dipping and thickening sequence of sand, silt, clay, and limestone. Beds primarily consisting of sand or limestone compose aquifers, and beds largely consisting of 


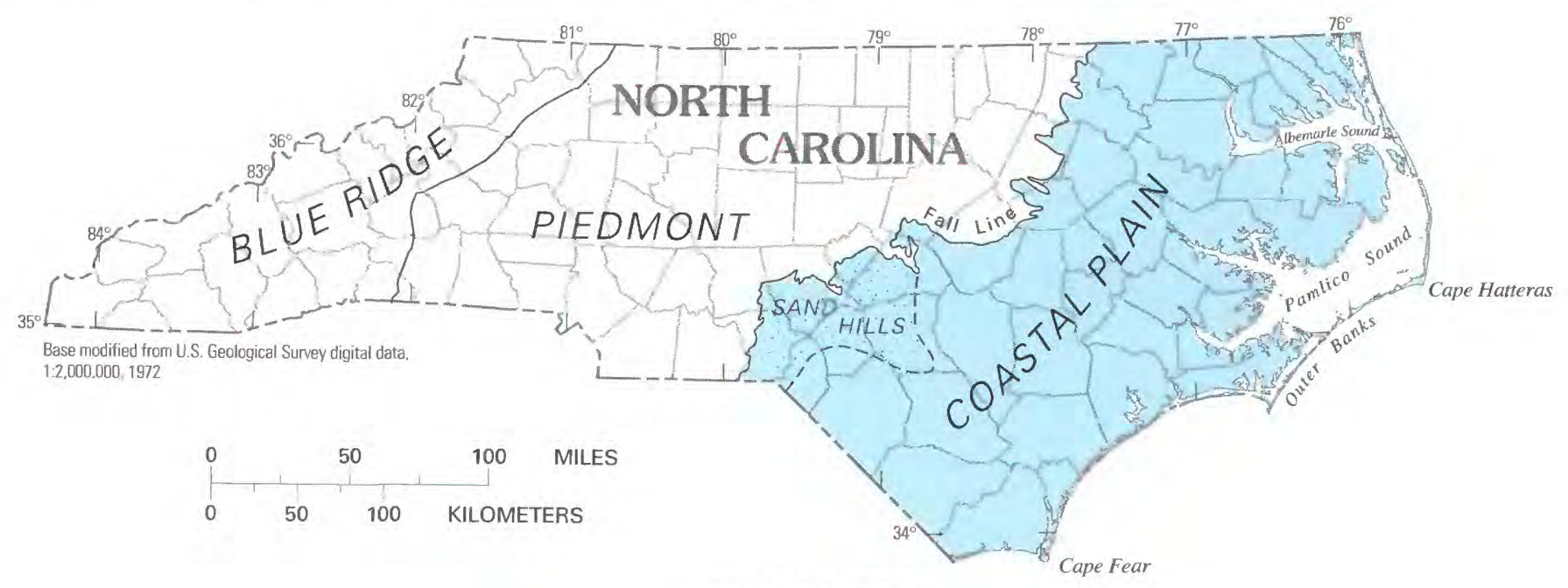

EXPLANATION

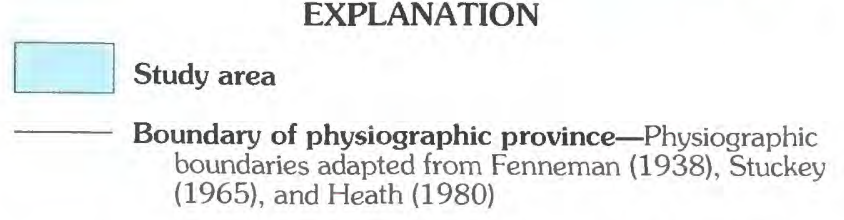

Figure 1.-Study area of the North Carolina Coastal Plain aquifer system.

clay and silt are confining units. This sequence of aquifers and confining units is considered to function as a single aquifer system.

Water derived from aquifers of the North Carolina Coastal Plain aquifer system constitutes the major source of water for municipal and domestic water supplies; it is also an important source of water for industrial and agricultural purposes. Total ground-water withdrawal in the North Carolina Coastal Plain for 1980 is estimated at more than 250 million gallons per day (Mgal/ d). However, this pumpage of ground water, both in the North Carolina Coastal Plain and in adjacent States, has led to several hydrogeologic problems. These problems include lowering of ground-water levels in some areas, reduction of base flow to streams, creation of the potential for land subsidence, and movement of saltwater and contaminated water into the areas used for water supplies.

Effective planning for use of ground water in the Coastal Plain is needed to provide for future watersupply needs while minimizing potentially adverse effects of this development. Such planning requires a detailed qualitative and quantitative understanding of the functioning of the ground-water flow system and the response of the aquifer system to existing and proposed pumping stresses. To help develop such understanding, a subregional investigation of the aquifer system of the North Carolina Coastal Plain was begun in 1979 as part of a larger regional study of the Northern Atlantic
Coastal Plain aquifer system (fig. 2). Both studies are part of the U.S. Geological Survey's Regional Aquifer-System Analysis (RASA) program. The larger regional RASA study covers about $50,000 \mathrm{mi}^{2}$ of the Coastal Plain areas of New York, New Jersey, Delaware, Maryland, Virginia, and North Carolina. Other subregional RASA studies were conducted in each of the other States, and all were coordinated at State lines. The broad objectives for all of the studies were similar-to assemble geologic, hydrologic, and geochemical information, to analyze and develop an understanding of the aquifer system, and to develop capabilities that will be used to aid in the effective management of ground-water resources.

The final results of the Northern Atlantic Coastal Plain RASA study are described in U.S. Geological Survey Professional Paper 1404. This report is chapter M of Professional Paper 1404. Other chapters that relate directly to this chapter are listed below:

Chapter A. "The Regional Aquifer System Underlying the Northern Atlantic Coastal Plain in Parts of North Carolina, Virginia, Maryland, Delaware, New Jersey, and New York-Summary."

Chapter D. "The Occurrence and Geochemistry of Salty Ground Water in the Northern Atlantic Coastal Plain."

Chapter F. "Conceptualization and Analysis of GroundWater Flow System in the Coastal Plain 


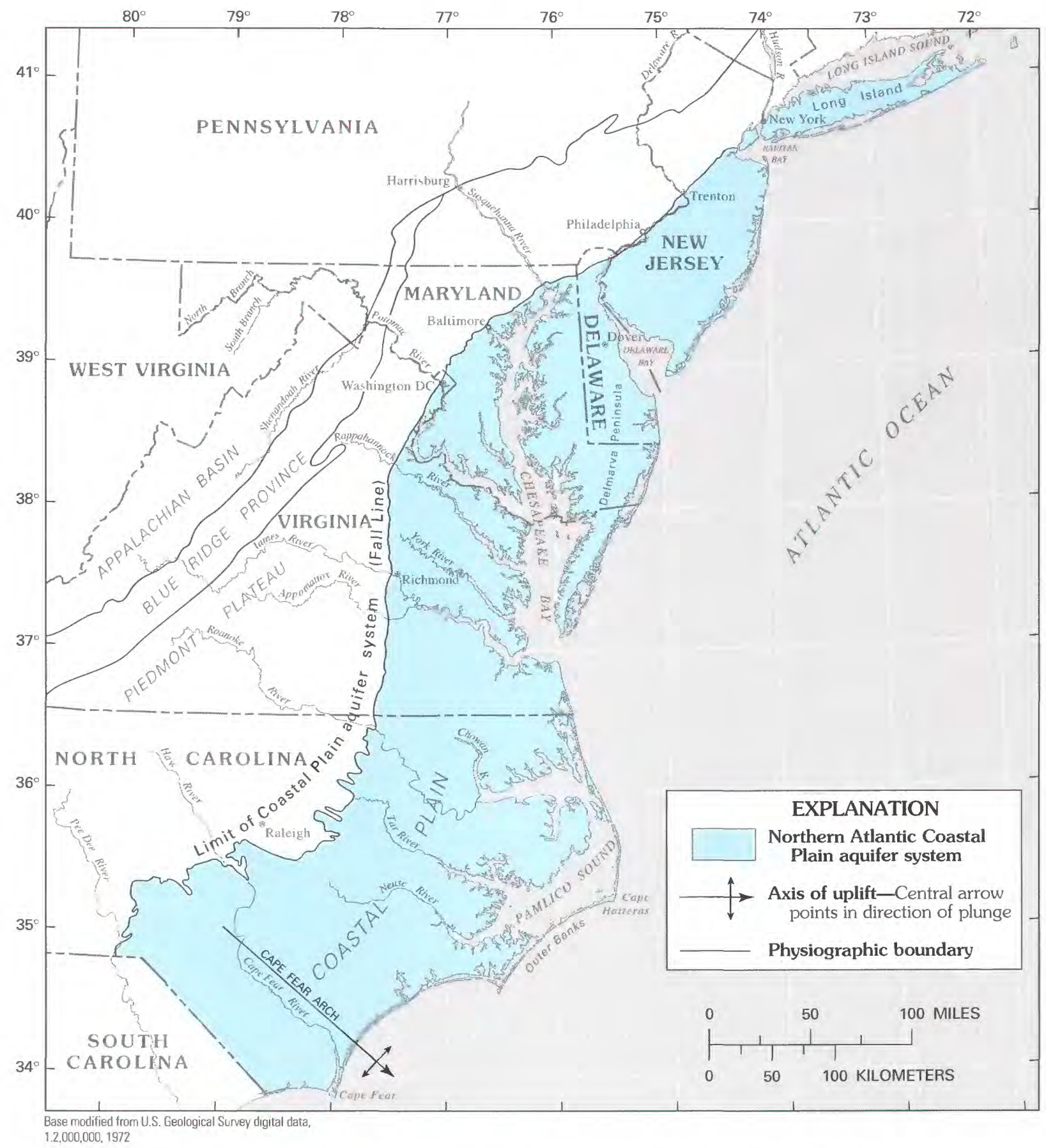

FigURE 2.-The Northern Atlantic Coastal Plain study area (modified from Meisler, 1986). 
[Aquifers] of Virginia and Adjacent Parts of Maryland and North Carolina."

Chapter G. "Hydrogeologic Framework of the Northern Atlantic Coastal Plain in Parts of North Carolina, Virginia, Maryland, Delaware, New Jersey, and New York."

Chapter I. "Hydrogeologic Framework of the North Carolina Coastal Plain."

Chapter K. "Geohydrology and Simulation of GroundWater Flow in the Northern Atlantic Coastal Plain Aquifer System."

Chapter L. "Geochemistry of the Northern Atlantic Coastal Plain Aquifer System."

\section{PURPOSE AND SCOPE}

The purpose of this report is to describe the simulation of ground-water flow in the Coastal Plain of North Carolina for conditions prior to and after development of ground water. A finite-difference ground-water flow model was applied to 10 aquifers and intervening confining units, each of which covers all or part of the State's 25,000- $\mathrm{mi}^{2}$ Coastal Plain. Discussions include modeling procedures and boundary conditions, calibration, sensitivity analysis, steady state for prepumping conditions, and transient simulations for 1900-80 conditions.

Results of the simulations are discussed with respect to changes in ground-water flow as shown by changes in the water budget, potentiometric surface of each aquifer, and direction of ground-water flow vertically through the confining units. Results are also presented for a simulation of the year 2000 using an assumed constant increase in pumping of 3 percent per year from 1980 to 2000 at all 1980 pumping locations.

\section{METHODS OF INVESTIGATION}

This study was conducted in three stages. The first stage consisted of the development of a conceptual model of the ground-water flow system for the North Carolina Coastal Plain. This conceptual model is based on the hydrogeologic framework of Winner and Coble (1989, 1996), estimates of aquifer and confining-unit properties, and general concepts as to the functioning of the system-including patterns of ground-water movement, nature of the system boundaries, and rates and locations of recharge and discharge.

The second stage of the study involved the mathematical representation of the aquifer system. Elements of the conceptual model of the aquifer system were translated into numerical data sets suitable for manipulation in a mathematical-numerical model, which is a combination of a system of mathematical equations representing the behavior of the ground-water flow system and numerical procedures for solving the equations. A computer program described by Trescott (1975) and modified by Leahy (1982) was used to solve the governing equations of ground-water flow.

Simulated water levels resulting from model trials were compared with measured levels during the period 1900-80 to determine how realistically the digital model reproduced actual water levels. Model parameters were varied in order to improve the match between the observed and simulated water levels and to reduce errors in parameter estimates. When the model reproduced observed water levels within an acceptable range, the model was considered to be calibrated. For each trial set of model parameters, a series of three simulations was made (discussed in detail in the "Model Calibration" section of this report).

A sensitivity analysis was then performed on the calibrated model to determine the general degree of improvement of model parameter values as a result of the model calibration. The analysis consisted of evaluating the effect on model results caused by changing each of the model parameters. If model results showed little variation over a broad range of variation of a given parameter, then the model was said to be insensitive to that parameter, and it is not probable that the calibration process improved the estimates of the parameter. Conversely, if model results showed great sensitivity to a given parameter, then changes made in that parameter to improve agreement of model results with observed water levels likely resulted in improved estimates of that parameter. A computer printout of the model parameters used in the calibrated model is on file at the District Office, U.S. Geological Survey, P.O. Box 30728, Raleigh, NC 27607.

The third stage of the study was hydrologic analysis of the aquifer system for predevelopment and development conditions. The analysis involved comparison of water levels in aquifers and vertical flow through confining units for the years 1900 (predevelopment) and 1980 (development). A predictive analysis was also done for the year 2000, assuming a 3-percent annual increase in pumping from 1980.

These three stages were largely, but not entirely, consecutive in time. For example, work done in digital model calibration at times revealed a need to revise previous concepts of the hydrogeologic framework. This, in turn, led to a revised digital model and affected the results of the hydrologic analysis.

\section{PREVIOUS INVESTIGATIONS}

Winner and Coble $(1989,1996)$ described the hydrogeologic framework for the North Carolina Coastal Plain, which is used and briefly described in this report. Sev- 
eral of the previous hydrogeologic investigations that have contributed significantly to knowledge of the hydrogeology of North Carolina Coastal Plain sediments are mentioned below; however, the reader is referred to the Winner and Coble reports for a more complete review of these investigations.

Clark and others (1912) reported on the first comprehensive survey of the geology and ground-water resources of the North Carolina Coastal Plain. LeGrand (1964) presented a broad review of the hydrogeology of the Atlantic and Gulf Coastal Plains and discussed important hydrologic concepts related to the functioning of the ground-water reservoir throughout this large region. Brown and others (1972) identified 17 chronostratigraphic units that are more or less continuous throughout the Coastal Plain from New York to North Carolina. On the basis of geophysical logs, driller logs, and well cuttings, lithofacies and indices of intrinsic permeability for each unit were mapped and estimated.

Other discussions of ground-water hydrology of multicounty areas in the North Carolina Coastal Plain are contained in Mundorff (1946), Brown (1959), LeGrand (1960), Schipf (1961), Nelson (1964, 1976), Blankenship (1965), Nelson and Barksdale (1965), Harris and Wilder (1966), DeWiest and others (1967), Floyd and Peace (1974), Peek (1977), and Narkunas (1980); these are listed in the "Selected References" section at the end of this report.

Publications describing simulation of ground-water flow in the Coastal Plain of North Carolina are limited. Cosner (1975) simulated ground-water flow in the Lower Cretaceous aquifer in southeastern Virginia and parts of northeastern North Carolina, utilizing a finite-difference model. Sherwani (1973) developed a two-dimensional finite-difference model of the Castle Hayne aquifer in the Lee Creek area in Beaufort County, primarily as a tool for evaluating the effects of dewatering operations for phosphate mining on the potentiometric surface. LayneWestern Company (1983) developed a steady-state electric-analog model to simulate flow in the Cretaceous aquifer system of southeastern Virginia and northeastern North Carolina.

\section{ACKNOWLEDGMENTS}

Data relating to the development of the hydrogeologic framework and conceptualization of the flow system were furnished by personnel in the Groundwater Section, Division of Environmental Management, in the North Carolina Department of Environment, Health, and Natural Resources (DEHNR). The specific individuals deserving special thanks are Perry F. Nelson, William Jeter, Carl Bailey, Richard Shiver, Edward Berry, William Bright, and L.A. Register.

\section{CONCEPTUALIZATION OF THE AQUIFER SYSTEM}

In this report, the conceptual model of the ground-water flow system of the North Carolina Coastal Plain is presented in a partly qualitative fashion. General ideas are discussed concerning the functioning of the aquifer system, particularly the ways recharge and discharge occur, how water moves through the system, an understanding of the physical environment through which flow occurs, and the nature of the system boundaries.

The source of water for the aquifer system is recharge from precipitation to the surficial aquifer, which, for the most part, is under water-table conditions. Figure 3 illustrates a generalized water budget for a typical location in the North Carolina Coastal Plain (Wilder and others, 1978). The budget shown in figure 3 represents predevelopment (steady-state) conditions in which water entering the aquifer system is equal to the water leaving it. Precipitation is about 50 inches per year (in/yr). Of this amount, about 33 inches (in.) is lost through evapotranspiration, about 5 in. is lost through overland runoff, and about 12 in. infiltrates to the water table (fig. 3). Of this 12 in., about $11 \mathrm{in.} \mathrm{moves} \mathrm{laterally} \mathrm{to}$ streams. In most places, about 1 in. or less moves vertically down through confining units to the confined ground-water flow system. Water generally moves down into the confined aquifers in interstream areas. In downdip coastward areas (fig. 4), it generally moves up from the confined aquifers into streambeds of large rivers and into sounds and the ocean.

For modeling purposes, flow through confining units is considered to be primarily vertical, as shown in figure 4 , and flow through aquifers is considered to be horizontal. The unconsolidated Coastal Plain aquifer system is underlain by crystalline basement rocks of low permeability. It is assumed that there is little significant exchange of water between the basement rocks and the Coastal Plain aquifers; therefore, the top of the basement rocks is considered as a no-flow boundary for the aquifer system.

Fresh ground water in Coastal Plain aquifers usually grades into saltwater near the coastline. At some point in each aquifer, the effect of saltwater density balances the freshwater head potential so that ground-water movement becomes insignificant. In this study, this is assumed to occur at the point where the chloride concentration in ground water is $10,000 \mathrm{mg} / \mathrm{L}$. The seaward limit of ground water containing less than $10,000 \mathrm{mg} / \mathrm{L}$ of chloride, as given by Meisler (1981), is considered as a no-flow boundary.

The hydrogeologic framework of Winner and Coble $(1989,1996)$ for the Coastal Plain of North Carolina, out- 


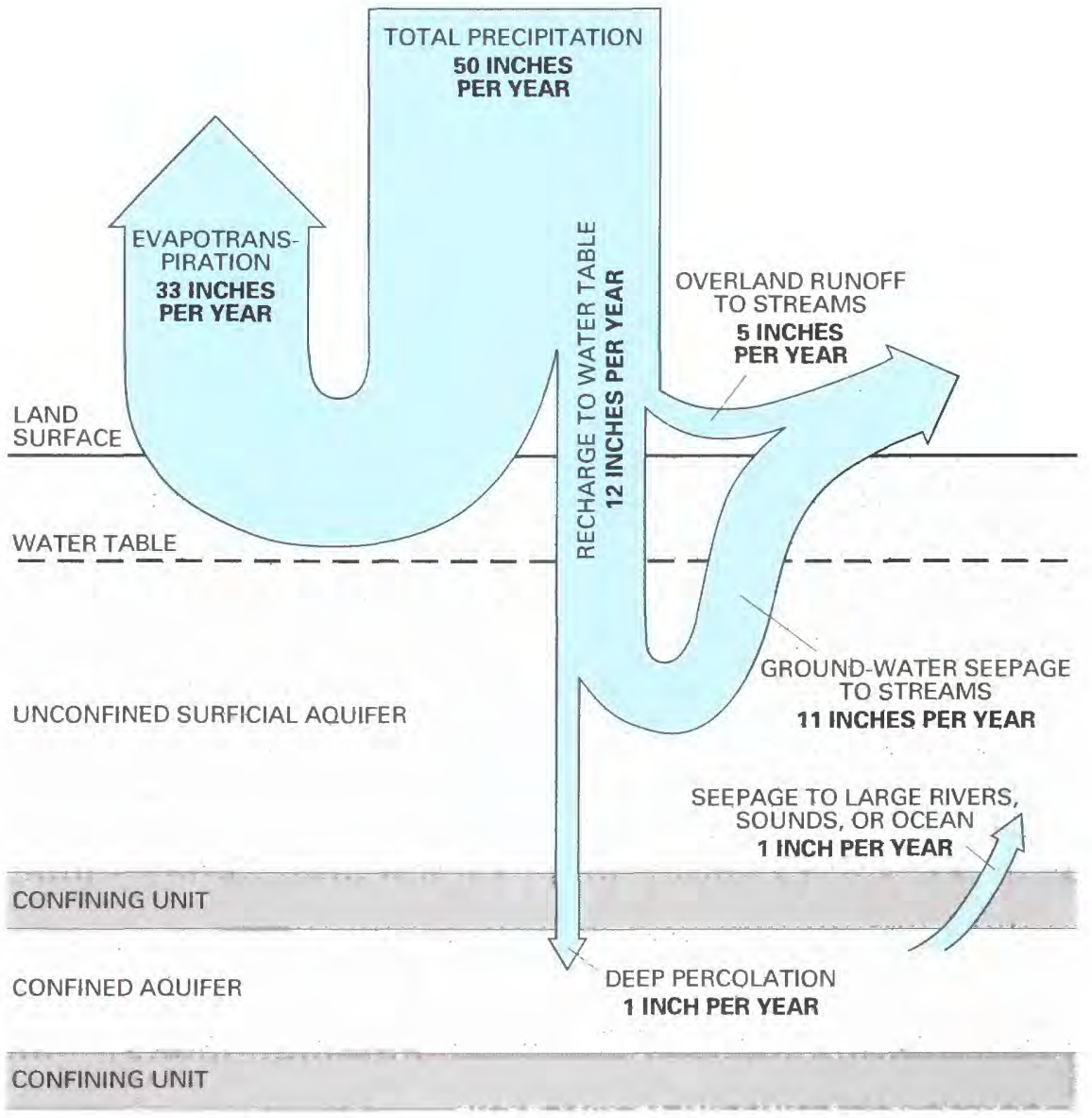

Figure 3.-Typical annual water budget for the North Carolina Coastal Plain hydrogeologic system (modified from Wilder and others, 1978). 


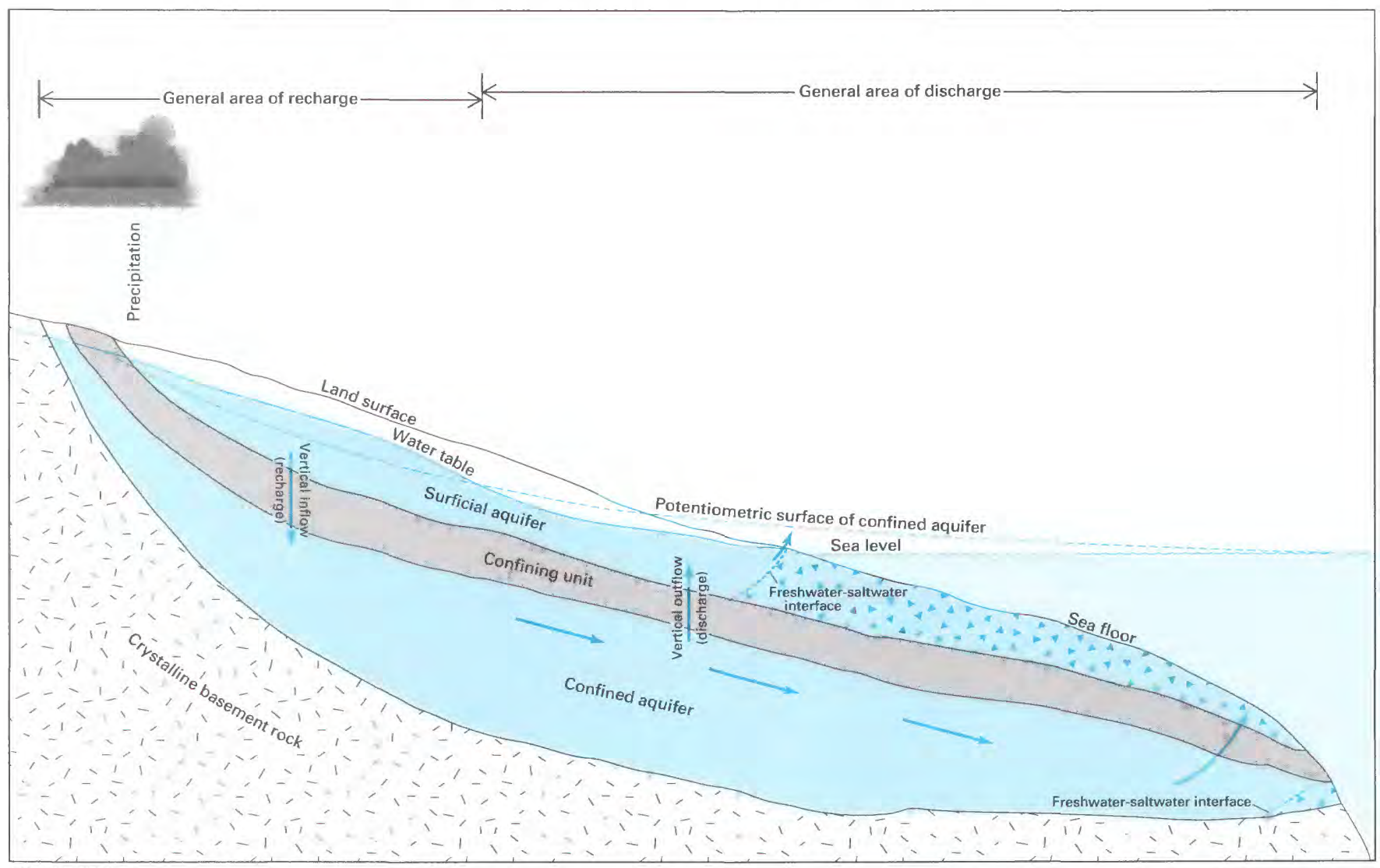

NOT TO SCALE

FIGURE 4.-Idealized hydrogeologic cross section showing features of the ground-water flow system. Arrows indicate general direction of ground-water flow. 
lined in the following section of the report, served as the primary basis for the initial numerical representation of the flow system in the digital model. Other aspects of the conceptual model of the flow system, including recharge and discharge, movement of water through the system, and the nature of the system boundaries are discussed later in the report as they relate to the digital flow model.

\section{HYDROGEOLOGIC FRAMEWORK}

The hydrogeologic framework presented by Winner and Coble $(1989,1996)$ consists of 10 aquifers and 9 confining units (table 1). However, these hydrogeologic units do not occur everywhere in the North Carolina Coastal Plain. Equivalent hydrogeologic units for neighboring States are also shown in table 1, although some of these

TABLE 1.-Hydrogeologic units for North Carolina, South Carolina, and Virginia Coastal Plain

[Modified from Winner and Coble, 1989, 1996]

\begin{tabular}{|c|c|c|c|}
\hline \multirow[b]{2}{*}{ Virginia hydrogeologic units ${ }^{1}$} & \multicolumn{2}{|l|}{ North Carolina } & \multirow[b]{2}{*}{ South Carolina hydrogeologic units ${ }^{2}$} \\
\hline & Hydrogeologic units & $\begin{array}{c}\text { Model layer } \\
\text { number }\end{array}$ & \\
\hline Columbia aquifer & Surficial aquifer & A10 & Surficial aquifer \\
\hline Yorktown confining unit & Yorktown confining unit & CU9 & \multirow{13}{*}{$\begin{array}{l}\text { Hydrogeologic units equivalent to } \\
\text { North Carolina units not present } \\
\text { in northeastern South Carolina }{ }^{3}\end{array}$} \\
\hline Yorktown-Eastover aquifer & Yorktown aquifer & A9 & \\
\hline St. Marys confining unit & Pungo River confining unit & CU8 & \\
\hline St. Marys-Choptank aquifer & Pungo River aquifer & A8 & \\
\hline Calvert confining unit & Castle Hayne confining unit & CU7 & \\
\hline Chickahominy-Piney Point aquifer & Castle Hayne aquifer & A7 & \\
\hline Nanjemoy-Marlboro Clay confining unit & Beaufort confining unit & CU6 & \\
\hline Aquia aquifer & \multirow{3}{*}{ Beaufort aquifer } & \multirow{3}{*}{ A6 } & \\
\hline Brightseat confining unit ${ }^{4}$ & & & \\
\hline Brightseat aquifer ${ }^{4}$ & & & \\
\hline \multirow{2}{*}{$\begin{array}{l}\text { Hydrogeologic units equivalent to North } \\
\text { Carolina units not present in Virginia }\end{array}$} & Peedee confining unit & CU5 & \\
\hline & Peedee aquifer & A5 & \\
\hline Virginia Beach confining unit ${ }^{5}$ & Black Creek confining unit & CU4 & \\
\hline \multirow{3}{*}{ Virginia Beach aquifer 5} & \multirow{3}{*}{ Black Creek aquifer } & \multirow{3}{*}{ A4 } & Black Creek aquifer \\
\hline & & & Unnamed confining unit \\
\hline & & & Middendorf aquifer \\
\hline Upper Potomac confining unit & Upper Cape Fear confining unit & CU3 & Unnamed confining unit \\
\hline Upper Potomac aquifer & Upper Cape Fear aquifer & A3 & \multirow{5}{*}{ Cape Fear aquifer } \\
\hline Middle Potomac confining unit & Lower Cape Fear confining unit & CU2 & \\
\hline Middle Potomac aquifer & Lower Cape Fear aquifer & $\mathrm{A} 2$ & \\
\hline Lower Potomac confining unit & Lower Cretaceous confining unit ${ }^{6}$ & CU1 & \\
\hline Lower Potomac aquifer & Lower Cretaceous aquifer 6 & A1 & \\
\hline \multicolumn{4}{|c|}{$\begin{array}{l}{ }^{1} \text { Meng and Harsh (1988). } \\
{ }^{2} \text { Southeastern Coastal Plain aquifer system (Aucott and others, 1987). } \\
{ }^{3} \text { Tertiary equivalents (Floridan and Tertiary sand aquifers) are present in the central and southern South Carolina Coastal Plain (Aucott and others, 1987). } \\
{ }^{4} \text { Restricted to northern Virginia; not present along North Carolina-Virginia boundary. } \\
{ }^{5} \text { Hamilton and Larson (1988). } \\
{ }^{6} \text { Restricted to northern North Carolina; not present along North Carolina-South Carolina boundary. }\end{array}$} \\
\hline
\end{tabular}



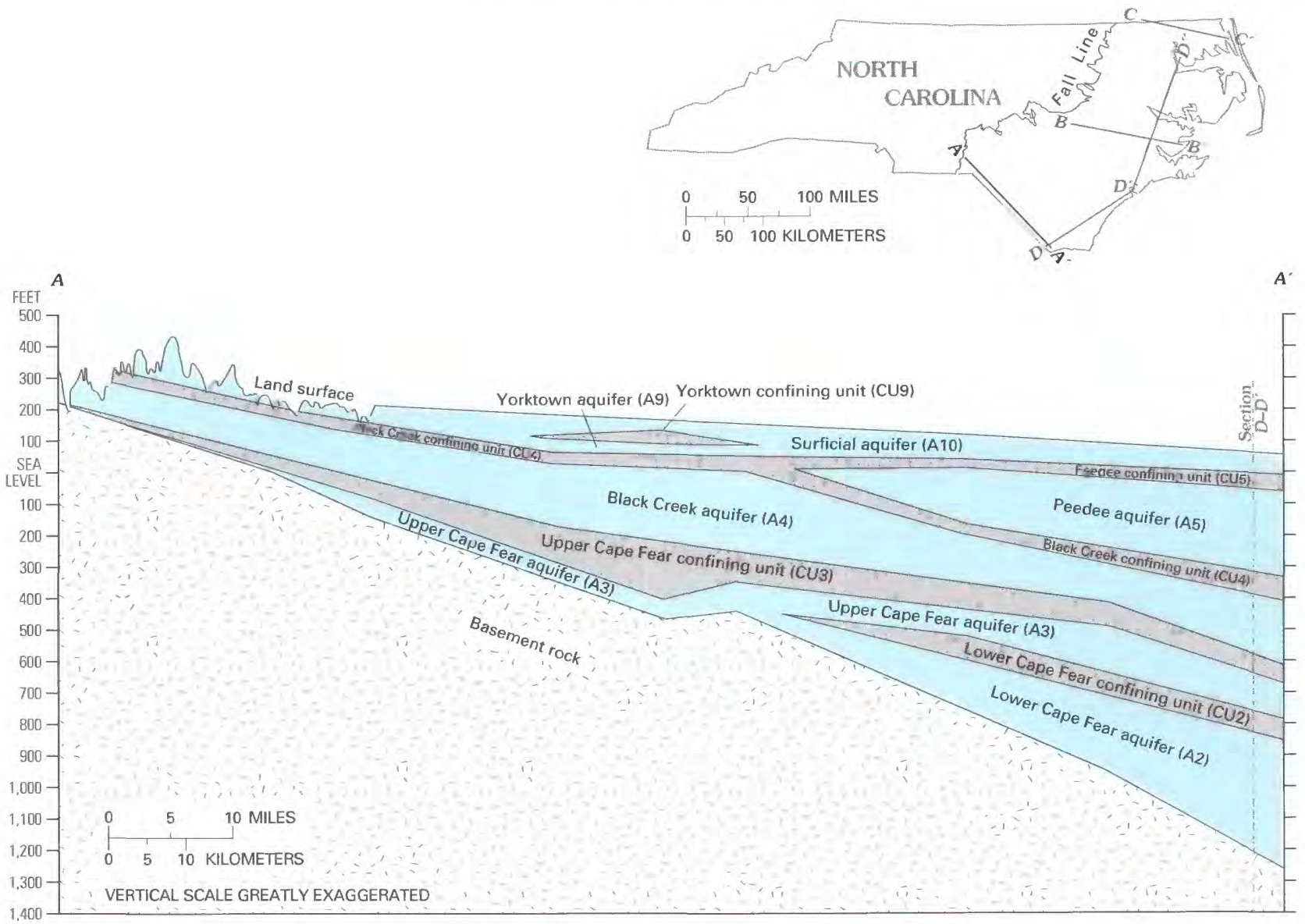

Figure 5.-Hydrogeologic section $A-A^{\prime}$ from Richmond County to Brunswick County (modified from Winner and Coble, 1989).

are not present at the respective borders with North Carolina.

For the convenience of constructing a digital model of the ground-water flow system, the hydrogeologic units are sometimes abbreviated using a letter and number as shown in table 1. Aquifers (A) are numbered from the lowest unit upward; confining unit (CU) designations are taken from the aquifers they overlie. Thus, aquifer $\mathrm{A} 1$ is the lowermost aquifer, and the confining unit overlying it is CU1. These designations are referred to frequently in this report.

Selected hydrogeologic sections were adapted from Winner and Coble (1989) to show the distribution of aquifers and confining units throughout the North Carolina Coastal Plain (figs. 5-9). The idealized sections show the thickening, thinning, and pinchouts typical of these hydrogeologic units in the study area. Confining units are considered to terminate at the limit of the underlying aquifer. These relations are built into the modeling process, and the reader is referred to Winner and Coble
(1989) for detailed geologic and hydrologic descriptions. Brief descriptions of each hydrogeologic unit are presented in this section.

\section{SURFICIAL AQUIFER}

The surficial aquifer (A10) overlies all of the North Carolina Coastal Plain (fig. 1) and consists of fine sand, silt, clay, shell, soil, residuum, and peat beds. Scattered deposits of coarser grained sediments in the unit occur in relict beach ridges or in alluvium. Throughout the western and central parts of the Coastal Plain, the thickness of the surficial aquifer ranges from a few feet to about 30 feet (ft); however, the aquifer thickens eastward and is more than $200 \mathrm{ft}$ thick in the vicinity of the Outer Banks. The sediments of the surficial aquifer are primarily of post-Yorktown age, but are not restricted to a single geologic unit in terms of age or lithology (Winner and Coble, 1989). 

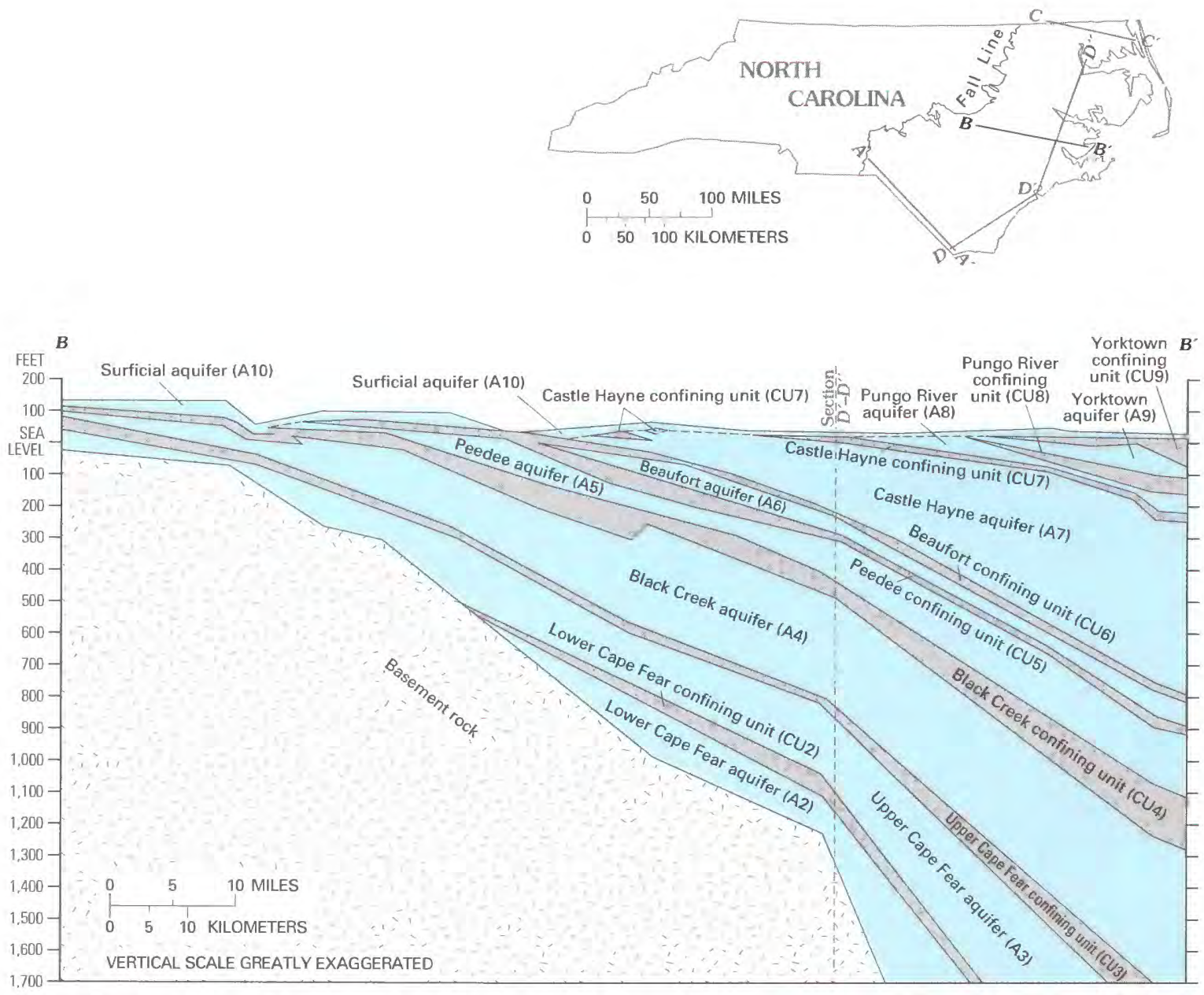

FIGURE 6.-Hydrogeologic section $B-B^{\prime}$ from Johnston County to Pamlico County (modified from Winner and Coble, 1989). 

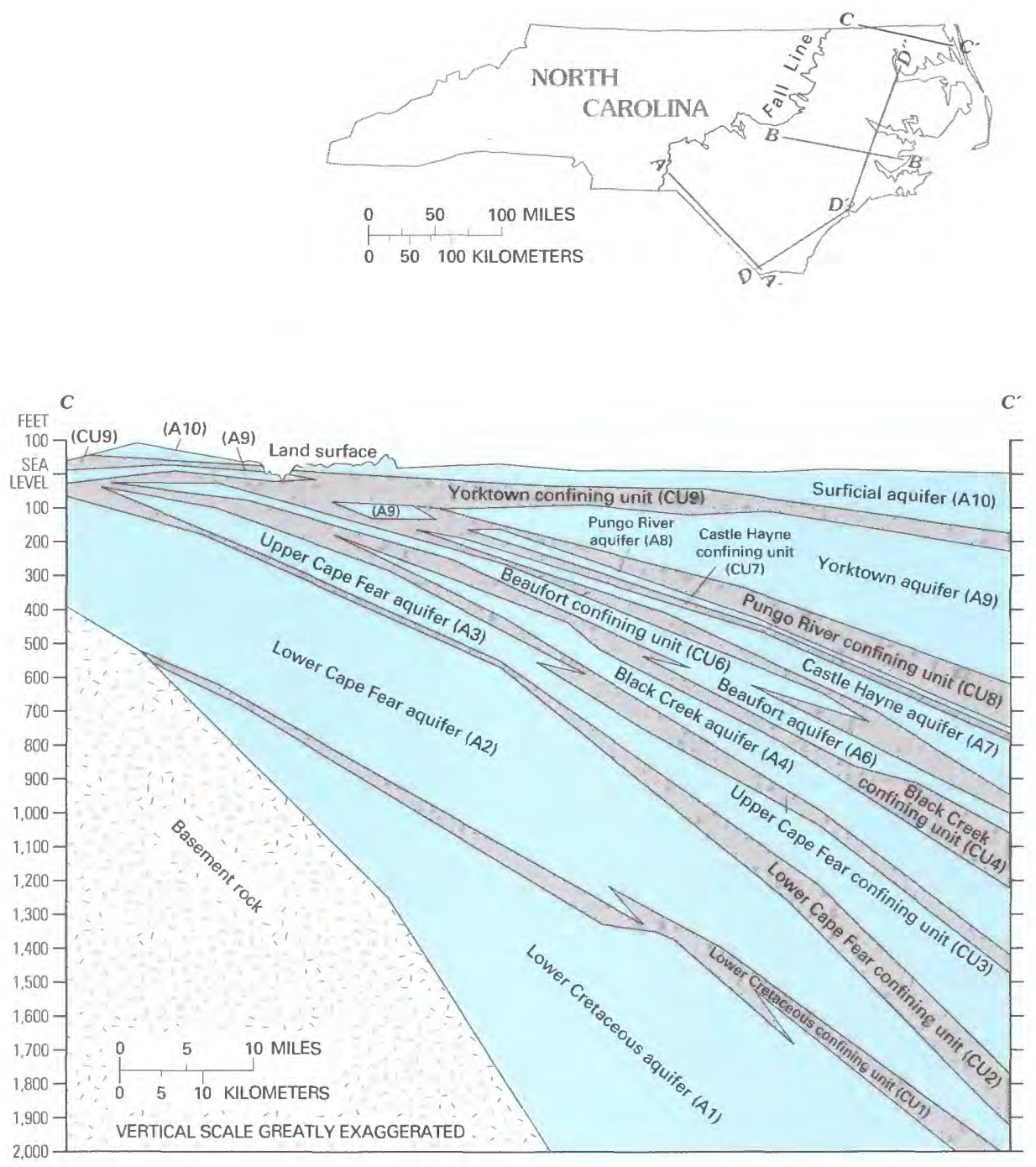

Figure 7.-Hydrogeologic section $C-C^{\prime}$ from Southampton County, Va., to Currituck County, N.C. (modified from Winner and Coble, 1989). 

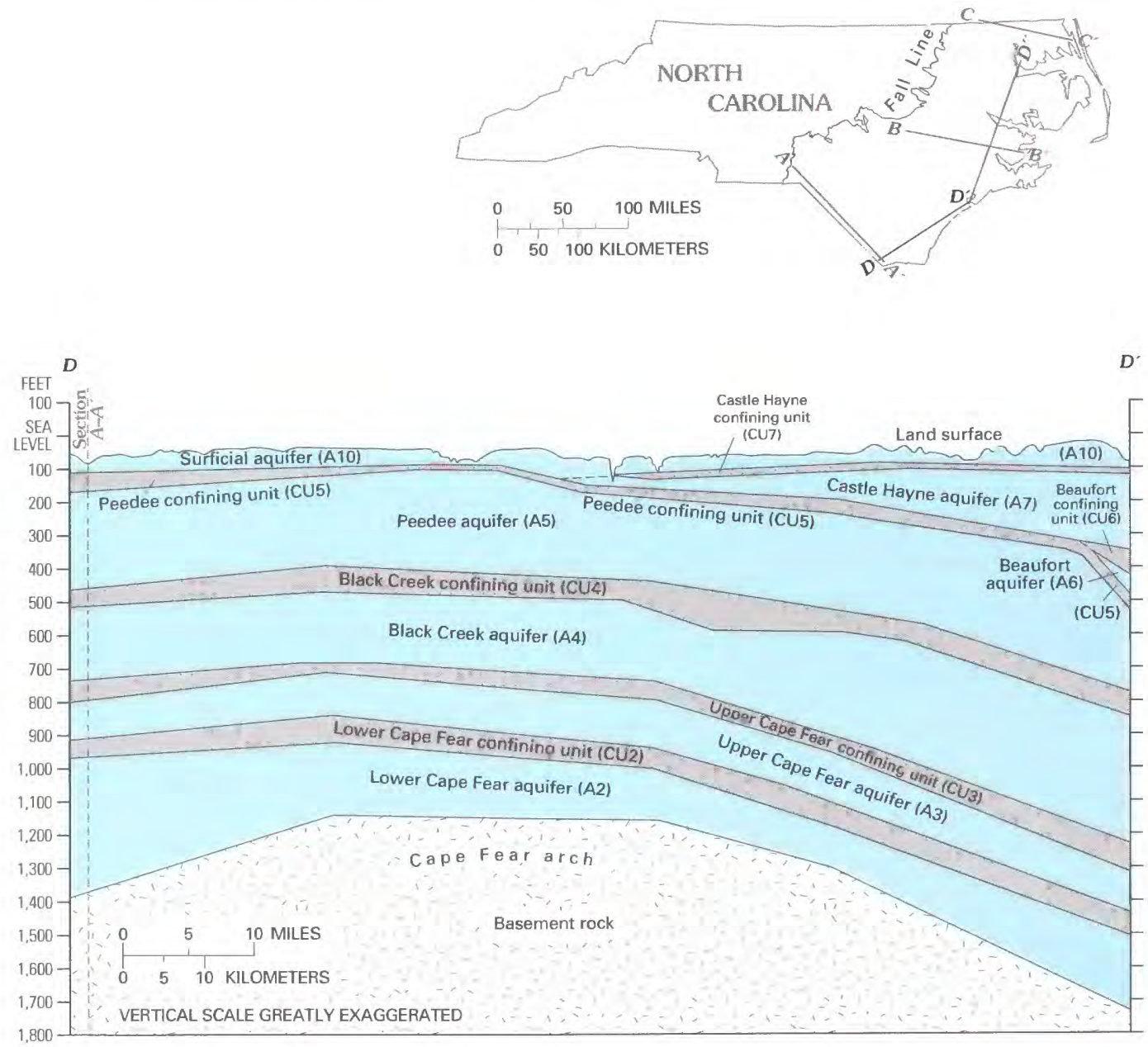

Figure 8.-Hydrogeologic section $D-D^{\prime}$ from Brunswick County to Onslow County (modified from Winner and Coble, 1989). 

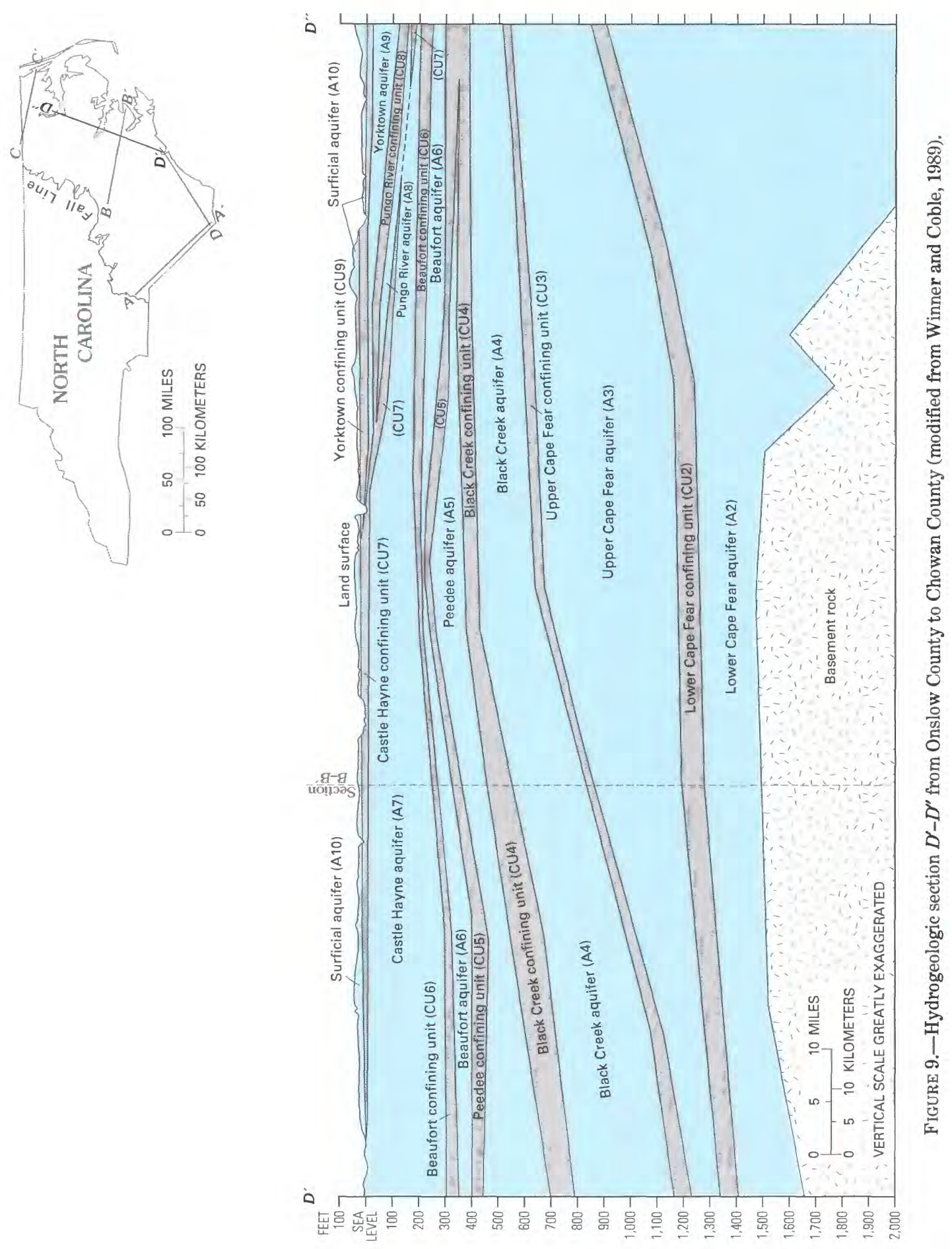
The surficial aquifer (A10) directly overlies most of the confined aquifers at one place or another and exchanges water with them either directly or through an intervening confining bed. The surficial aquifer receives direct recharge from precipitation and is the source of water for the deeper confined aquifers and base flow to streams. The amount of recharge from precipitation varies areally from about 12 to $20 \mathrm{in} / \mathrm{yr}$, depending on the clay content of the soils. Winner and Coble $(1989 ; 1996$, table 4) estimated the average horizontal hydraulic conductivity of the surficial aquifer to be 29 feet per day $(\mathrm{ft} / \mathrm{d})$. A more detailed description of movement of water within the surficial aquifer is given in the section entitled "Model Input."

\section{YORKTOWN AQUIFER AND OVERLYING CONFINING UNTT}

The Yorktown aquifer (A9) is equated with the older beds of the Pliocene Yorktown Formation of Clark and others (1912) and extends throughout the northern half of the Coastal Plain (fig. 10) from the Fall Line, where it overlies crystalline rocks similar to those in the Piedmont, eastward to beyond the coast. The Yorktown aquifer largely consists of fine sand, silty and clayey sand, sand with shells and shell beds, some limestone, and some coarse sand beds. In the western Coastal Plain, the aquifer is relatively thin, less than $20 \mathrm{ft}$ thick in many places, and has been cut into or eroded away by the larger streams flowing across the area. In Dare County, the Yorktown aquifer attains its maximum thickness of more than $300 \mathrm{ft}$.

The Yorktown aquifer (A9) does not extend into the southern half of the Coastal Plain, except for a small area in Robeson County (fig. 10), which is the largest of a number of outliers shown by Brown and others (1972, pl. 21). Figure 10 also shows the areal extent of aquifers that underlie the Yorktown aquifer. The surficial aquifer (A10) overlies the Yorktown aquifer everywhere.

The estimated horizontal hydraulic conductivity of the Yorktown aquifer ranges from 19 to $33 \mathrm{ft} / \mathrm{d}$ and averages about $22 \mathrm{ft} / \mathrm{d}$, based on aquifer tests and lithologicand geophysical-log data from 52 wells and test holes (Winner and Coble, 1989, 1996).

The Yorktown confining unit (CU9) overlying the Yorktown aquifer consists of the youngest clay beds of the Yorktown Formation in most places, but locally may be clay beds of Pleistocene or Holocene age. Its thickness averages about $25 \mathrm{ft}$, ranging from less than $10 \mathrm{ft}$ up to $70 \mathrm{ft}$ thick. It is composed largely of clay and sandy clay and local beds of fine sand or shell. The Yorktown confining unit generally is considered to extend only as far as the Yorktown aquifer, even though stratigraphically equivalent beds may continue beyond the aquifer limits.

\section{PUNGO RIVER AQUIFER AND OVERLYING CONFINING UNIT}

The Pungo River aquifer (A8) consists of the permeable part of the Pungo River Formation of early and middle Miocene age, described in detail by Kimrey (1965). The Pungo River aquifer is composed of fine to medium marine sands having considerable phosphate content. The average horizontal hydraulic conductivity, based on analysis of geophysical logs, is estimated to be $33 \mathrm{ft} / \mathrm{d}$, according to Winner and Coble (1989). Shells and other fossils are present throughout the aquifer; occasionally, beds of limestone and coarse sand are found.

The Pungo River aquifer (A8) is thinnest near its western and northern limits, where its thickness averages about $15 \mathrm{ft}$. The aquifer dips eastward and thickens to more than $200 \mathrm{ft}$ in the vicinity of the Outer Banks, where the top is deeper than $700 \mathrm{ft}$ below sea level. The aquifer is overlain everywhere by aquifers A9 or A10 (fig. 11), except where it is exposed in an open-pit phosphate mine in Beaufort County. The Pungo River aquifer is underlain everywhere by the Castle Hayne aquifer (A7).

The Pungo River confining unit (CU8) is formed by the upper clay beds of the Pungo River Formation and contiguous clays of the lowermost Yorktown Formation. The confining unit ranges in thickness from less than 10 $\mathrm{ft}$ near the western margin to about $150 \mathrm{ft}$ beneath Currituck County, and the average thickness is nearly $55 \mathrm{ft}$. For most of the area, the confining unit is composed of nearly uniform clay containing less than 10 percent sand.

\section{CASTLE HAYNE AQUIFER AND OVERLYING CONFINING UNIT}

The Castle Hayne aquifer (A7) is delineated as those calcareous sediments of Eocene age that are equated with the Castle Hayne Limestone and the Trent Formation of former usage of Clark and others (1912). Also part of this aquifer are the rocks of Oligocene age, now designated River Bend Formation, overlying the Castle Hayne (Brown and others, 1972), which are lithologically identical and hydraulically connected to the Castle Hayne Limestone. The basal part of the aquifer may consist of older contiguous permeable units in local areas. The areal extent of this aquifer is shown in figure 12, which also shows the extent of overlying aquifers.

The Castle Hayne aquifer (A7) consists of limestone, sand, and minor amounts of clay deposited under marine conditions. Limestone may occur as shell limestone, dolomitic limestone, and sandy limestone ranging from loosely consolidated to hard and recrystallized. Along the western margin, the aquifer occurs near land surface from New Hanover County to Craven County. Eastward, the aquifer thickens to more than $950 \mathrm{ft}$ in Carteret County and to nearly 1,200 ft beneath Cape Hatteras (Brown, 1958, fig. 4). In the area north of Albemarle 


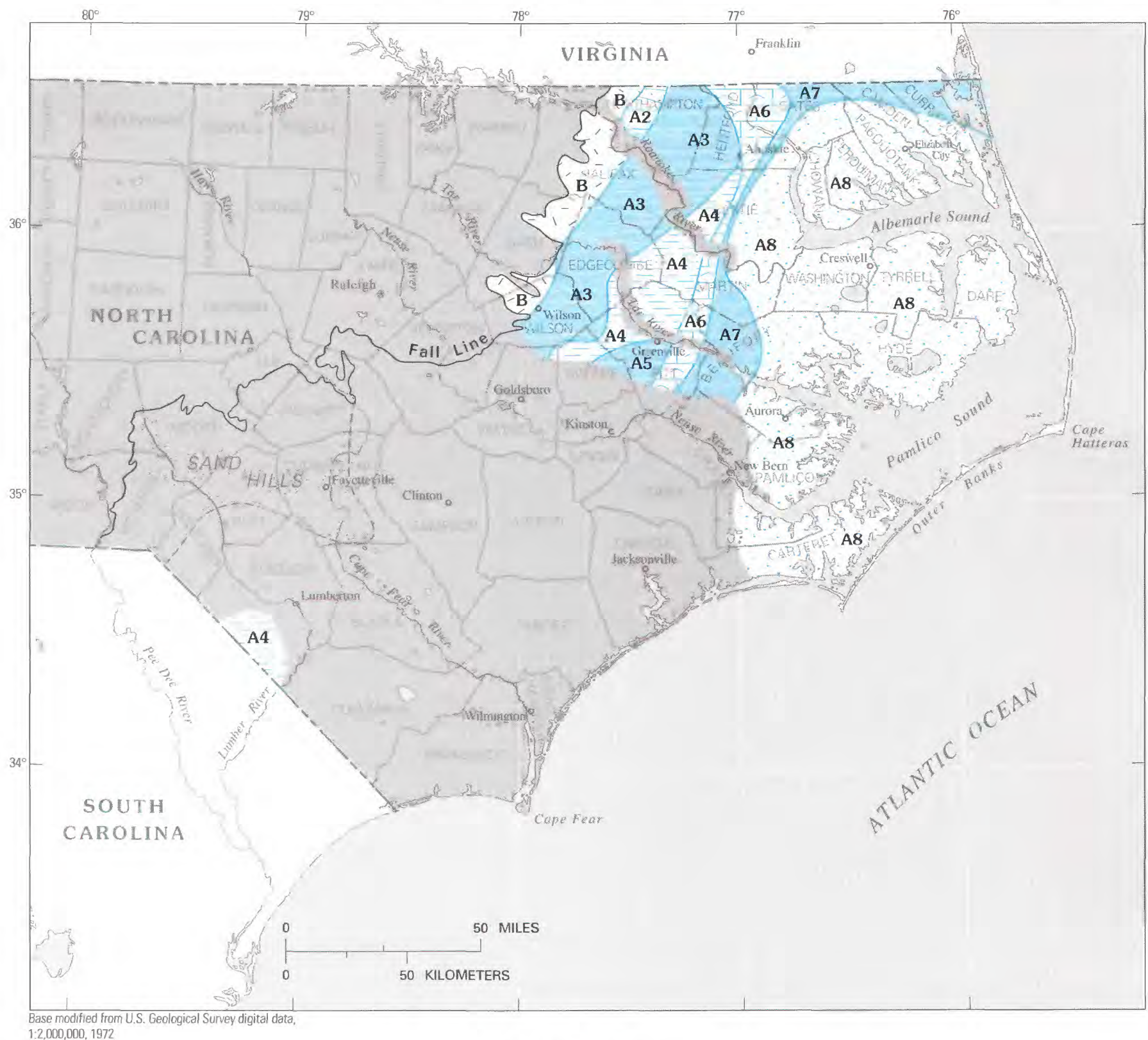

1.2,000,000, 1972

\section{EXPLANATION}

Yorktown aquifer not present

Limit and designation of aquifer and confining unit, or basement rock, directly underlying the Yorktown aquifer

A8 Pungo River aquifer and confining unit

A7 Castle Hayne aquifer and confining unit

A6 Beaufort aquifer and confining unit

A5 Peedee aquifer and confining unit

\begin{tabular}{|c|l}
\hline A4 & Black Creek aquifer and confining unit \\
\hline A3 & Upper Cape Fear aquifer and confining unit \\
A2 & Lower Cape Fear aquifer and confining unit \\
\hline B & Basement rock
\end{tabular}

FiguRE 10.-Areal extent of the Yorktown aquifer (A9) and underlying aquifers or basement rock (modified from Winner and Coble, 1989). 


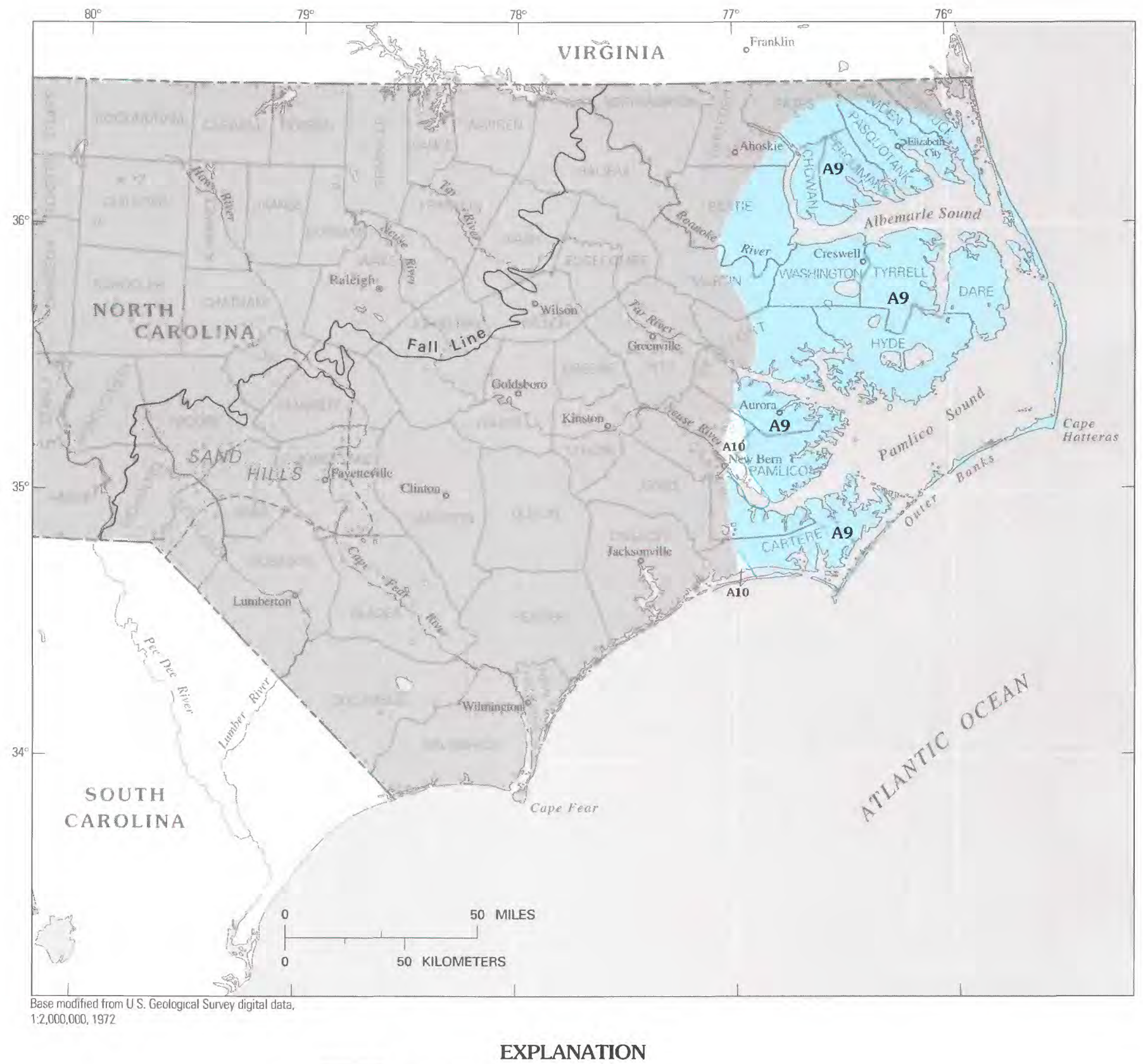

Pungo River aquifer not present

Limit and designation of aquifer and confining unit directly overlying the Pungo River aquifer

A10 Surficial aquifer

A9 Yorktown aquifer and confining unit

FIGURE 11.-Areal extent of the Pungo River aquifer (A8) and overlying aquifers (modified from Winner and Coble, 1989). 


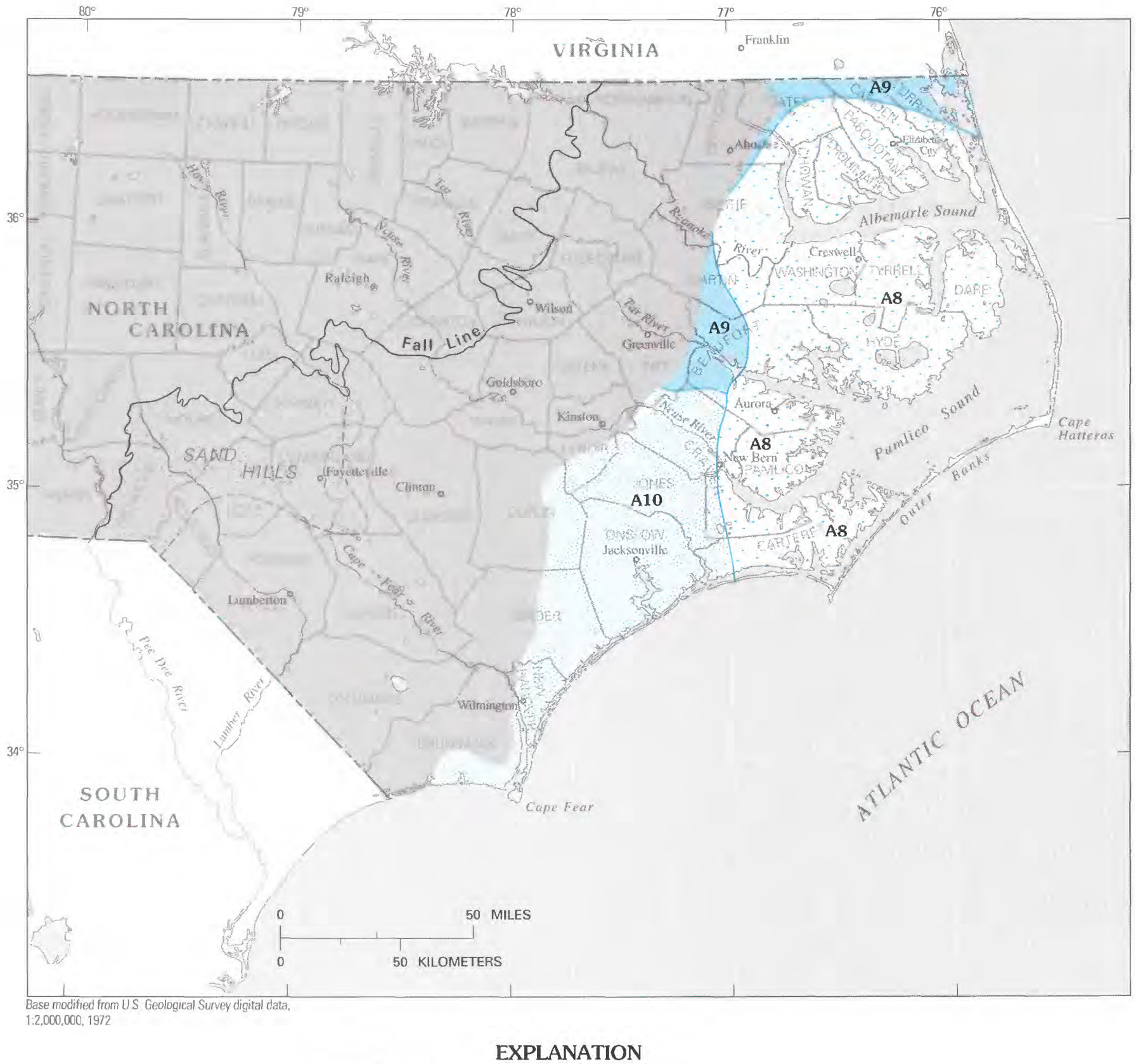

EXPLANATION

\section{Castle Hayne aquifer not present}

Limit and designation of aquifer and confining unit directly overlying the Castle Hayne aquifer

A10 Surficial aquifer

A9 Yorktown aquifer and confining unit

A8 Pungo River aquifer and confining unit

FIGURE 12.-Areal extent of the Castle Hayne aquifer (A7) and overlying aquifers (modified from Winner and Coble, 1989). 
Sound, limestone beds are thin to nonexistent, and the sediments contain more clay. The thickness of the unit averages about $50 \mathrm{ft}$ between Bertie and Currituck Counties but reaches a maximum of $164 \mathrm{ft}$ in Currituck County.

The Castle Hayne aquifer (A7) is the most productive aquifer in North Carolina due to its thickness and high percentage of permeable limestone and sand. On the basis of aquifer tests and lithologic- and geophysical-log data, the hydraulic conductivity of the Castle Hayne aquifer ranges from about $15 \mathrm{ft} / \mathrm{d}$, where it is composed of fine sand, to about $200 \mathrm{ft} / \mathrm{d}$, where the bulk of the aquifer is porous limestone.

The thickness of the Castle Hayne confining unit (CU7) averages only about $10 \mathrm{ft}$; it exceeds $25 \mathrm{ft}$ only in Gates County along the Virginia border, in eastern Pamlico and Carteret Counties, and in two small areas along the western limit of the Castle Hayne aquifer. The confining unit consists of beds of clay, sandy clay, and clay with sandy streaks that are part of the Pungo River Formation, the Yorktown Formation, or younger clays. The confining unit is missing in several stream valleys south of Craven County and in two areas in the northeastern Coastal Plain. In addition to being thinner than most of the other confining units, CU7 contains more sand; thus, it is relatively permeable and allows significant vertical leakage between the Castle Hayne aquifer and overlying aquifers.

Throughout most of their northern and eastern areas (fig. 12), the Castle Hayne aquifer (A7) and confining unit (CU7) are directly overlain by the Pungo River aquifer (A8), whereas to the south, the Castle Hayne aquifer is overlain by the Yorktown and surficial aquifers (A9 and A10). The Castle Hayne aquifer is directly underlain by the Beaufort aquifer (A6) and confining unit (CU6) northeast of Jones and Onslow Counties and by the Peedee aquifer (A5) and confining unit (CU5) southwest of these counties (fig. 13).

\section{BEAUFORT AQUIFER AND OVERLYING CONFINING UNIT}

The dark-green and gray sands and clays that were identified as the Beaufort Formation of Paleocene age by Brown (1959) and later identified as rocks of Midwayan age by Brown and others (1972) make up the bulk of the Beaufort aquifer (A6), the extent of which is shown in figure 14 . As with the other hydrogeologic units, the definition of this aquifer was not restricted to a single geologic formation; the Beaufort aquifer may include parts of rock units that are older than the Beaufort Formation (Winner and Coble, 1989, 1996).

The Beaufort aquifer (A6) consists of fine to medium glauconitic sands, clayey sands, and clay beds of marine origin. Shell and limestone beds are present but are less than $6 \mathrm{ft}$ thick. The thickness of the Beaufort aquifer ranges from less than $10 \mathrm{ft}$ along its western limit to more than $150 \mathrm{ft}$ in the northern part of its eastern limit. In Camden and Currituck Counties, the aquifer thins toward the east or northeast. The average horizontal hydraulic conductivity of the aquifer was estimated to be about $35 \mathrm{ft} / \mathrm{d}$, on the basis of lithologic and geophysical logs; lower than average values occurred in the northern and easternmost parts of the aquifer, where the sand is finer and the aquifer contains more clay.

The Beaufort confining unit (CU6) consists of the uppermost sediments of the Beaufort Formation and possibly some younger clay, silt, and sandy clay. Throughout most of the area, the confining unit shows a gradation from sandy clay to clay, but in places it contains distinct clay beds interlayered with fine sand or silt. The thickness of the confining unit ranges from zero to $80 \mathrm{ft}$ and averages about $24 \mathrm{ft}$. The thicker parts of the confining unit are in and northeast of Washington County.

The Beaufort aquifer (A6) is covered entirely by younger rocks (fig. 14). About 90 percent of the Beaufort aquifer and confining unit are overlain by the Castle Hayne aquifer (A7). The remainder is overlain by the Yorktown aquifer (A9) from Lenoir County northward (fig. 14). The upper Cape Fear, the Black Creek, and the Peedee aquifers and confining units underlie the Beaufort aquifer. The Peedee aquifer and confining unit (A5 and CU5) underlie about 80 percent of the area of the Beaufort aquifer (fig. 15).

\section{PEEDEE AQUIFER AND OVERLYING CONFINING UNIT}

The Peedee aquifer (A5) is named for the Upper Cretaceous Peedee Sand of Clark and others (1912, p. 145) and the Peedee Formation of Stephenson and Rathbun (1923, p. 11), of which the aquifer is largely composed. The areal extent of the Peedee aquifer and overlying units is shown in figure 16.

The Peedee aquifer (A5) consists of fine to medium sands interbedded with clays and silts. Thin beds of consolidated calcareous sandstone and impure limestone are interlayered among the sands in some places, particularly in the southeastern North Carolina Coastal Plain area. Shells are common throughout the unit. The top of the Peedee aquifer dips eastward at an average rate of about 24 feet per mile (ft/mi), but the dip varies from about $10 \mathrm{ft} / \mathrm{mi}$ in the western part to more than $32 \mathrm{ft} / \mathrm{mi}$ in the more deeply buried part along the coast. The aquifer thickness ranges from zero along its western limit to more than $300 \mathrm{ft}$ along the coast from southern Onslow County to the South Carolina border. Northeast of Onslow County, the maximum thickness of the aquifer is less than $200 \mathrm{ft}$, and the eastern one-third of the unit contains saltwater. The average horizontal hydraulic conductivity of the Peedee aquifer was estimated from 


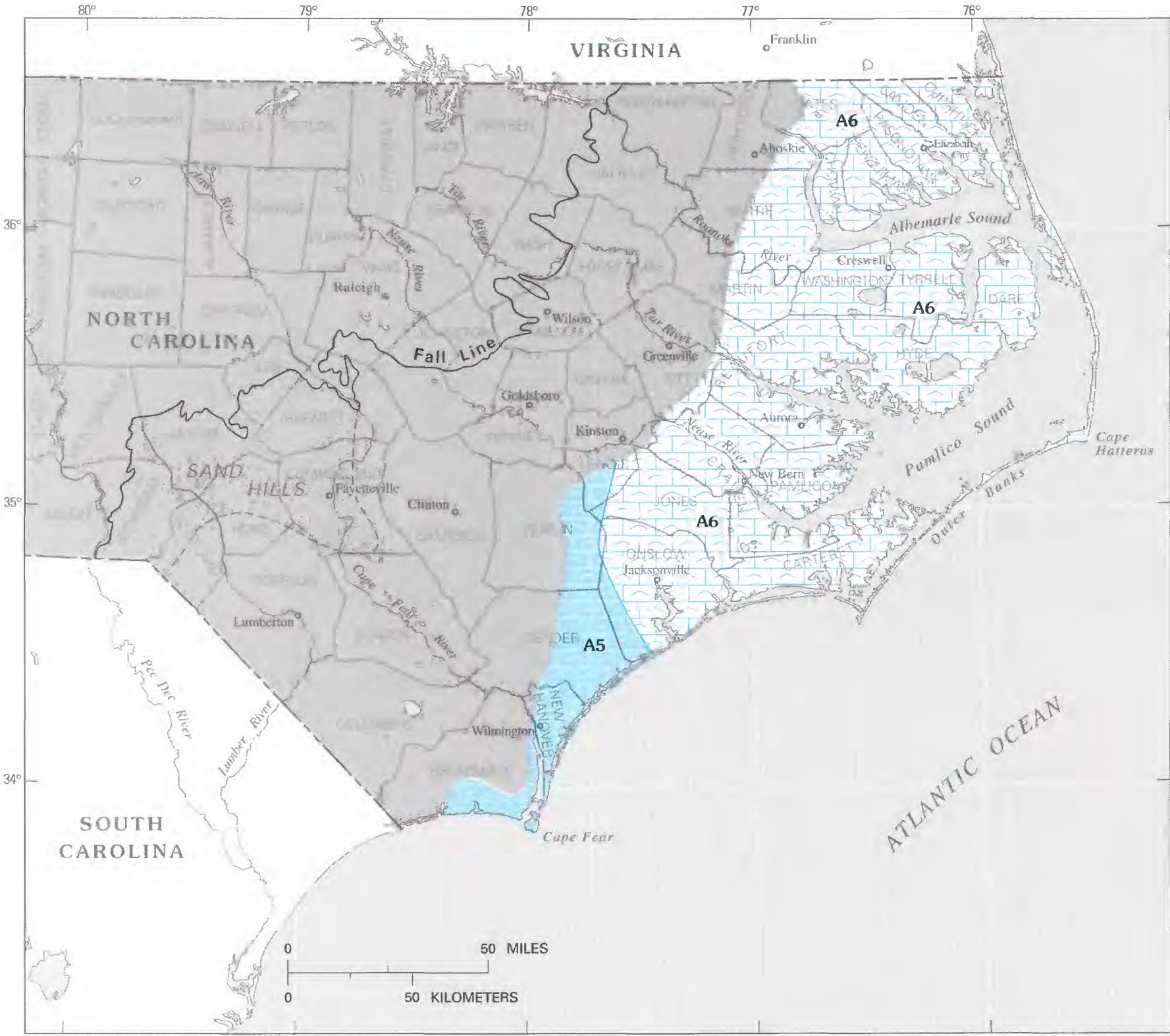

Base modified from U.S. Geological Survey digital data $1.2,000,000,1972$

\section{EXPLANATION}

\section{Castle Hayne aquifer not present}

Limit and designation of aquifer and confining unit directly underlying the Castle Hayne aquifer

A6

Beaufort aquifer and confining unit

Peedee aquifer and confining unit

FigURE 13.-Areal extent of the Castle Hayne aquifer (A7) and underlying aquifers (modified from Winner and Coble, 1989). 


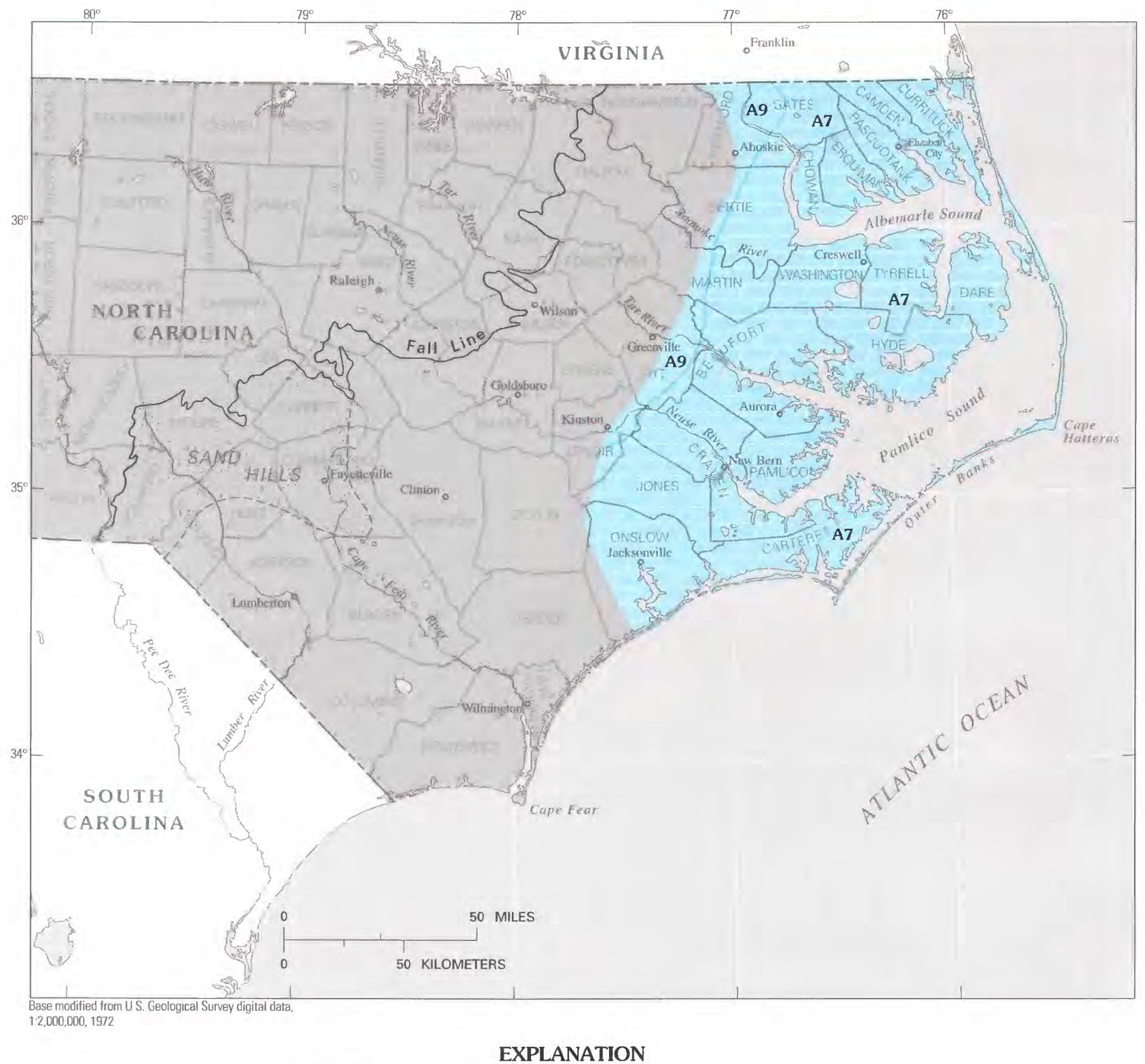

Beaufort aquifer not present

Limit and designation of aquifer and confining unit directly overlying the Beaufort aquifer

A9 Yorktown aquifer and confining unit

A7 Castle Hayne aquifer and confining unit

FIGURE 14,-Areal extent of the Beaufort aquifer (A6) and overlying aquifers (modified from Winner and Coble, 1989). 


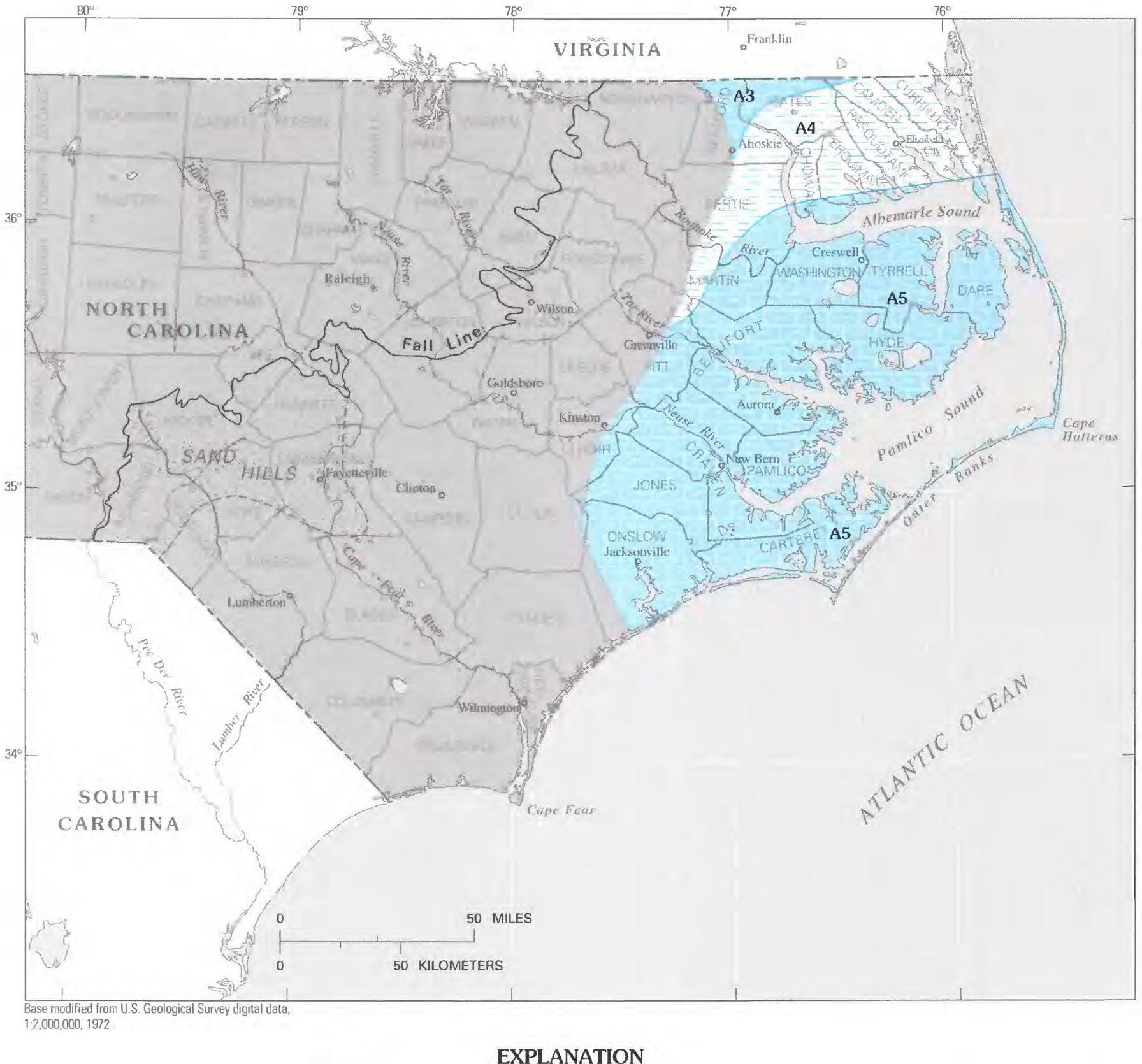

Beaufort aquifer not present

Limit and designation of aquifer and confining unit directly underlying the Beaufort aquifer
A5
Peedee aquifer and confining unit
A4
Black Creek aquifer and confining unit
Upper Cape Fear aquifer and confining unit

Figure 15.-Areal extent of the Beaufort aquifer (A6) and underlying aquifers (modified from Winner and Coble, 1989). 


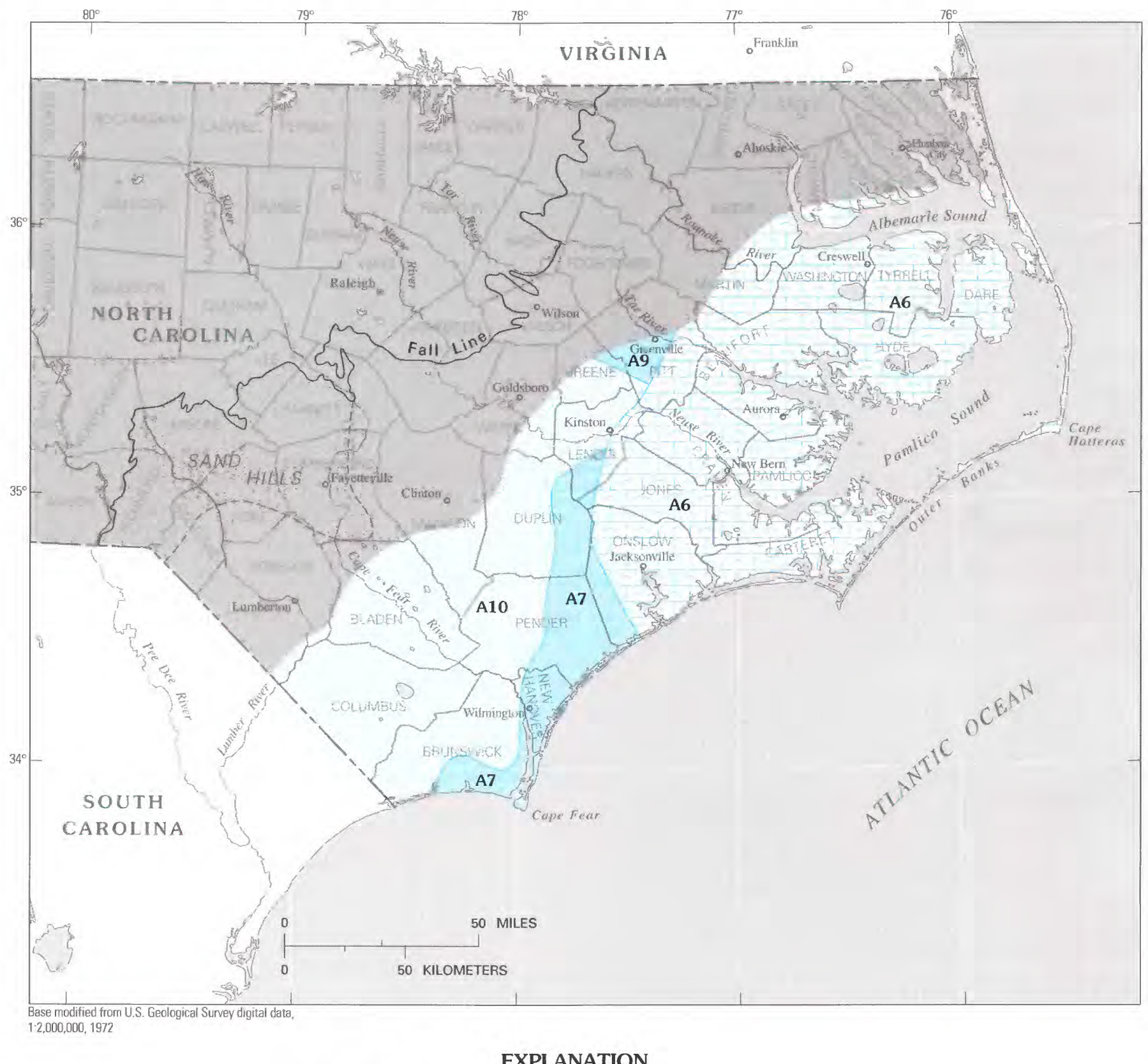

\section{EXPLANATION}

Peedee aquifer not present

Limit and designation of aquifer and confining unit directly overlying the Peedee aquifer

$\begin{array}{ll}\text { A10 Surficial aquifer } \\ \text { A9 Yorktown aquifer and confining unit } \\ \text { A7 Castle Hayne aquifer and confining unit } \\ \text { A6 } & \text { Beaufort aquifer and confining unit }\end{array}$

Figure 16.-Areal extent of the Peedee aquifer (A5) and overlying aquifers (modified from Winner and Coble, 1989). 
geophysical logs to be about $34 \mathrm{ft} / \mathrm{d}$ by Winner and Coble (1989).

The Peedee confining unit (CU5) is composed of clay, silty clay, and sandy clay. Winner and Coble $(1989,1996)$ did not identify the confining unit with a particular geologic unit, but the unit consists primarily of sediments at the Cenozoic-Mesozoic boundary. The average thickness of the Peedee confining unit is about $25 \mathrm{ft}$. In the eastern part of the confining unit, thickness may reach $60 \mathrm{ft}$ but commonly does not exceed 30 to $35 \mathrm{ft}$.

\section{BLACK CREEK AQUIFER AND OVERLYING CONFINING UNIT}

The Black Creek aquifer (A4) contains Upper Cretaceous sediments of both the Black Creek and underlying Middendorf Formations (Winner and Coble, 1989, 1996). The Black Creek Formation consists mainly of thinly laminated gray to black clay, interbedded with gray to tan sands. Outcrops also exhibit sand- or clay-dominated lenses. The Middendorf Formation consists mainly of fine to medium sand, interbedded with silty clay, coarser channel sand, and thinly laminated sand and clay. The horizontal hydraulic conductivity of the Black Creek aquifer, as estimated by Winner and Coble $(1989,1996)$, ranges from about 15 to $50 \mathrm{ft} / \mathrm{d}$, based on geophysical logs and aquifer tests.

The Black Creek aquifer and confining unit (A4 and CU4) are overlain by the Peedee (A5 and CU5), Beaufort (A6 and CU6), and Yorktown (A9 and CU9) aquifers and confining units and by the surficial aquifer (A10) (fig. 17). The Peedee aquifer overlies the eastern two-thirds of the Black Creek aquifer and confining unit. The surficial aquifer overlies the Black Creek aquifer and confining unit from the Fall Line to the updip limit of the Peedee aquifer in the southern North Carolina Coastal Plain, except for a small area in Robeson County, where they are overlain by the Yorktown aquifer. The Yorktown and Beaufort aquifers overlie the Black Creek aquifer and confining unit along their western limits in the northern North Carolina Coastal Plain.

The Black Creek confining unit (CU4) is primarily composed of the uppermost beds of the Black Creek Formation and consists of clay, silty clay, and sandy clay. In the northern part of the North Carolina Coastal Plain, it may also contain clay of the lower parts of the Beaufort or Yorktown Formations. In the deeper subsurface, clay in the lower part of the Peedee Formation may also be a part of this confining unit. In the Sand Hills area (figs. 1, 17), where the Black Creek aquifer (A4) is composed of the Middendorf Formation, confining unit CU4 consists of the uppermost clay of the Middendorf Formation. In the highly dissected Sand Hills, clay of the Middendorf Formation is cut through in many places by streams; thus, the Black Creek confining unit does not exist at these locations. Farther east, the channels of larger streams, such as the Cape Fear and Neuse Rivers, also have cut through the confining unit to allow direct hydraulic connection between the streams and the Black Creek aquifer. The thickness of the confining unit averages about $45 \mathrm{ft}$, but it may be more than $165 \mathrm{ft}$ thick in places in the eastern part of the Coastal Plain.

\section{UPPER CAPE FEAR AQUIFER AND OVERLYING CONFINING UNIT}

Winner and Coble $(1989,1996)$ recognized that the Upper Cretaceous Cape Fear Formation could be separated into two distinct hydrogeologic units, largely on the basis of effective confining beds between the upper and lower parts in Brunswick and adjacent counties near the South Carolina border. The sediments of the upper Cape Fear aquifer are alternating beds of sand and clay. The individual beds are commonly 3 to $5 \mathrm{ft}$ thick but range up to $15 \mathrm{ft}$ in thickness.

The upper Cape Fear aquifer (A3) varies in thickness from about $10 \mathrm{ft}$ along its western edge to nearly 500 $\mathrm{ft}$ in central Tyrrell County. The average thickness of the aquifer is slightly more than $100 \mathrm{ft}$. The aquifer is thickest beneath the Albemarle-Pamlico Peninsula east of Beaufort and Washington Counties. The horizontal hydraulic conductivity of the aquifer was estimated from geophysical logs to average about $30 \mathrm{ft} / \mathrm{d}$, its values ranging from 10 to $70 \mathrm{ft} / \mathrm{d}$ (Winner and Coble, 1989).

As described by Winner and Coble (1989), the upper Cape Fear confining unit (CU3) consists of nearly continuous clay, silty clay, and sandy clay beds belonging either to the Middendorf Formation in the Sand Hills area or to the Black Creek Formation. The thickness of the confining unit averages about $48 \mathrm{ft}$ (Winner and Coble, 1989) but may exceed $100 \mathrm{ft}$ in places near the South Carolina border, near the southeastern corner of Duplin County, and in Dare County. Along the western limit of the upper Cape Fear aquifer (A3), the Cape Fear and Neuse Rivers have cut through the confining unit; the same is true along the Tar and Roanoke Rivers.

The upper Cape Fear aquifer and confining unit (A3 and CU3) are overlain by the Black Creek aquifer (A4) in about 90 percent of their area (fig. 18). The Yorktown aquifer (A9) overlies the upper Cape Fear aquifer in the northwest, and the Beaufort aquifer (A6) overlies it in parts of Gates, Camden, and Hertford Counties. A small patch of the surficial aquifer (A10) overlies the upper Cape Fear aquifer and confining unit in Wayne, Wilson, and Johnston Counties. The lower Cape Fear aquifer and confining unit (A2 and CU2) underlie the upper Cape Fear aquifer (A3) in about three-fourths of its area (fig. 19). Elsewhere, the upper Cape Fear aquifer is in contact with basement rocks. 


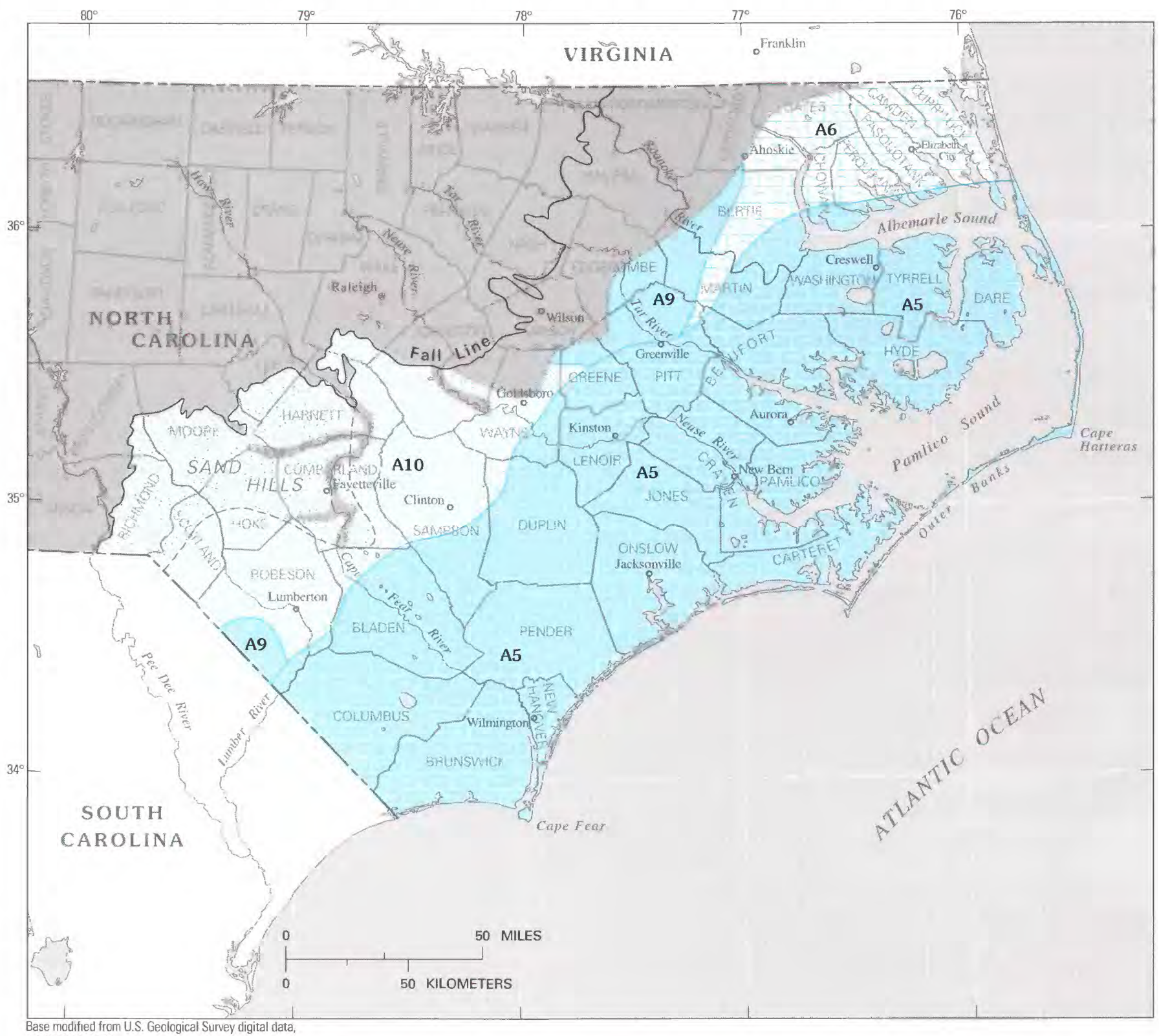

\section{EXPLANATION}

Black Creek aquifer not present

Limit and designation of aquifer and confining unit directly overlying the Black Creek aquifer

A10 Surficial aquifer

A9 Yorktown aquifer and confining unit

A6 Beaufort aquifer and confining unit

A5 Peedee aquifer and confining unit

Figure 17.-Areal extent of the Black Creek aquifer (A4) and overlying aquifers (modified from Winner and Coble, 1989). 


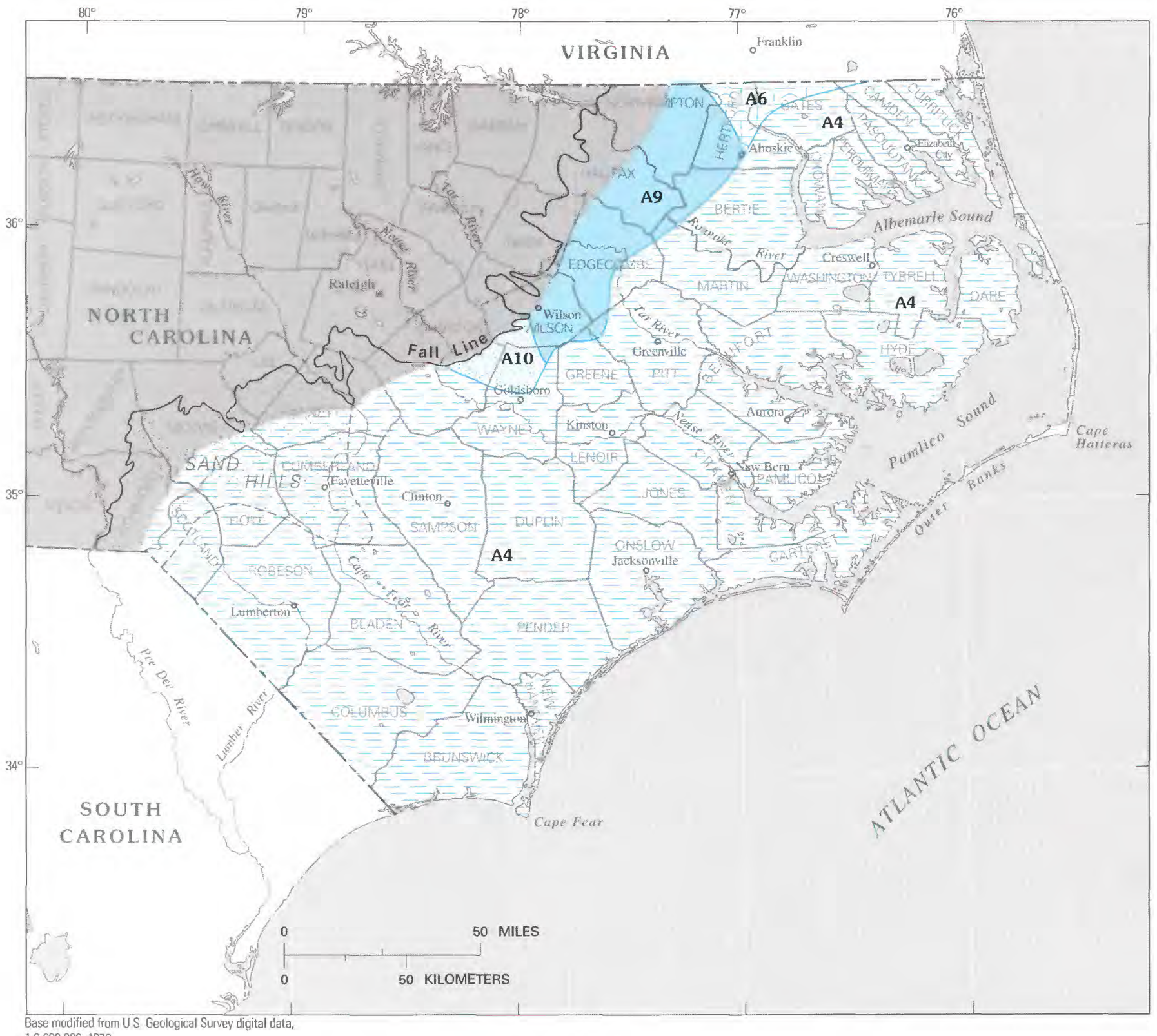

\section{EXPLANATION}

\section{Upper Cape Fear aquifer not present}

Limit and designation of aquifer and confining unit directly overlying the upper Cape Fear aquifer

\begin{tabular}{|c|l}
\hline A10 & Surficial aquifer \\
\cline { 1 - 1 } A9 & Yorktown aquifer and confining unit \\
\hline A6 & Beaufort aquifer and confining unit \\
\hline A4 & Black Creek aquifer and confining unit
\end{tabular}

FIGURE 18.-Areal extent of the upper Cape Fear aquifer (A3) and overlying aquifers (modified from Winner and Coble, 1989). 


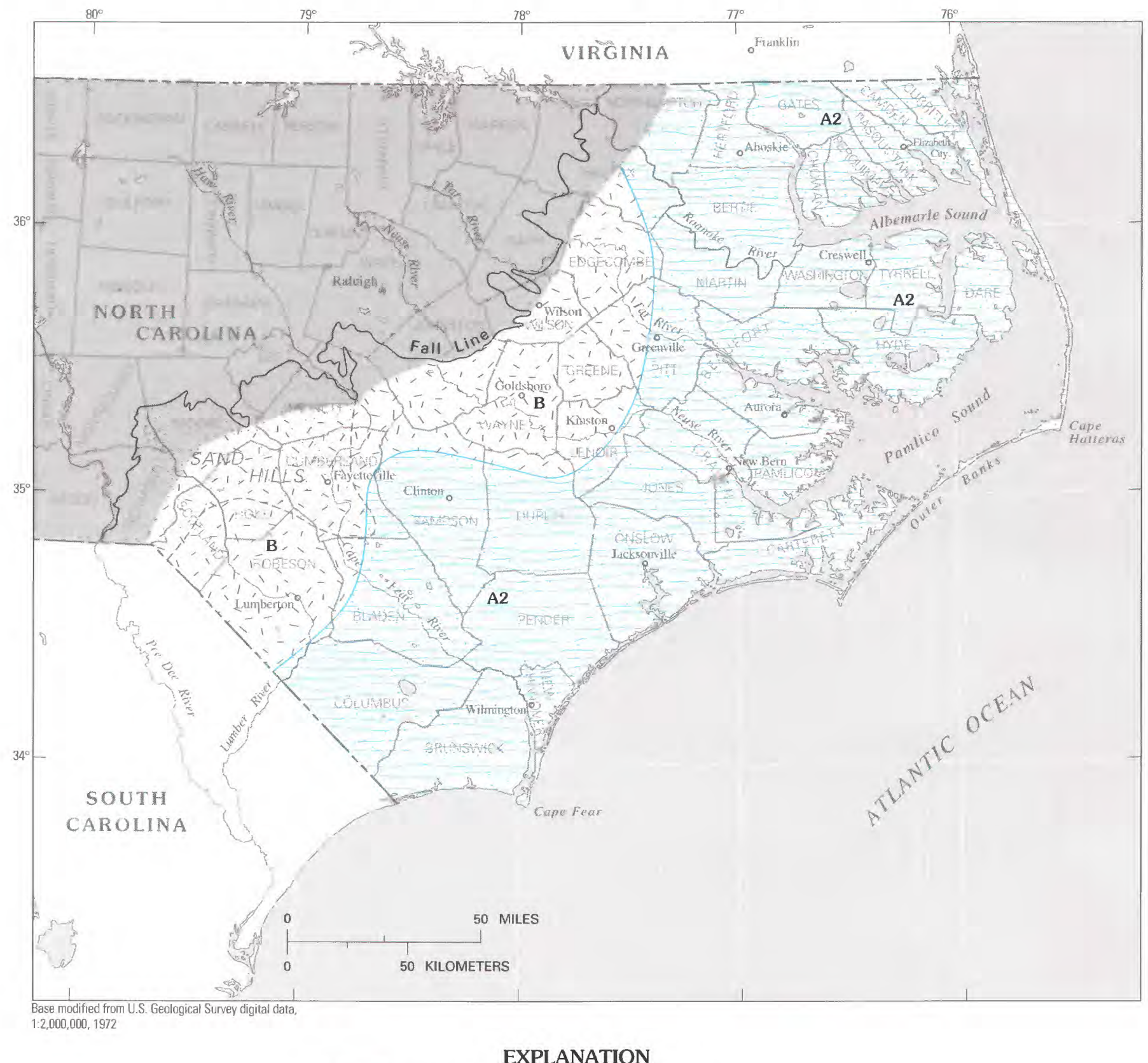

EXPLANATION

Upper Cape Fear aquifer not present

Limit and designation of aquifer and confining unit, or basement rock, directly underlying the upper Cape Fear aquifer

A2 Lower Cape Fear aquifer and confining unit

B - Basement rock

Figure 19-Areal extent of the upper Cape Fear aquifer (A3) and underlying aquifers or basement rock (modified from Winner and Coble, 1989). 


\section{LOWER CAPE FEAR AQUIFER AND OVERLYING CONFINING UNIT}

The lower Cape Fear aquifer (A2) consists mostly of older sand beds of the Cape Fear Formation, lithologically similar to those beds described for the upper Cape Fear aquifer (A3). In the southern North Carolina Coastal Plain, Winner and Coble (1989) viewed these sediments largely as a regressive phase of the Cape Fear Formation having a separate hydrologic identity from overlying Cape Fear sand units.

The lower Cape Fear aquifer (A2) strikes northeast and dips southwest at a rate of 15 to $35 \mathrm{ft} / \mathrm{mi}$. Its extent is shown in figure 20. Its thickness ranges from a few feet along its western margin to more than $400 \mathrm{ft}$ in the northeastern North Carolina Coastal Plain. The average hydraulic conductivity of the aquifer was estimated by Winner and Coble $(1989,1996)$ from geophysical logs to be about $34 \mathrm{ft} / \mathrm{d}$. Individual values ranged from 20 to 75 $\mathrm{ft} / \mathrm{d}$.

The lower Cape Fear confining unit (CU2) is composed of clay and sandy-clay beds that belong largely to the Cape Fear Formation. The average thickness of the confining unit is about $50 \mathrm{ft}$. The confining unit exceeds $75 \mathrm{ft}$ in thickness throughout the eastern quarter of the North Carolina Coastal Plain and in parts of Bertie and Halifax Counties and is more than $100 \mathrm{ft}$ thick in parts or all of Pasquotank, Camden, Currituck, Columbus, and Brunswick Counties.

The lower Cape Fear aquifer and confining unit (A2 and CU2) are overlain by the upper Cape Fear aquifer (A3) everywhere except for a small area near the Fall Line in Northampton County, where the Yorktown aquifer (A9) overlies them (fig. 20). The Lower Cretaceous aquifer and confining unit (A1 and CU1) underlie the lower Cape Fear aquifer in the eastern half of the North Carolina Coastal Plain (fig. 21). Elsewhere, the lower Cape Fear aquifer lies on basement rocks.

\section{LOWER CRETACEOUS AQUIFER AND OVERLYING CONFINING UNIT}

Sediments below the Cape Fear Formation are regarded by most investigators as belonging to the Lower Cretaceous Series and possibly include older rocks (Winner and Coble, 1989, 1996). Thus, the name Lower Cretaceous aquifer (A1) was chosen to designate this hydrogeologic unit, which is the lowermost aquifer defined in this study. The extent of aquifer A1 is shown in figure 21. Various investigators have established that the updip beds of the Lower Cretaceous aquifer are largely nonmarine in origin, but the incidence of beds of marine origin increases downdip toward the coast. The nonmarine beds are shales, sands, and gravel. Marine beds are chiefly limestones that may be sandy or dolomitic.
Data on horizontal hydraulic conductivity of the Lower Cretaceous aquifer are lacking in North Carolina, but Winner and Coble (1989) inferred from work by Brown and Cosner (1974) that the hydraulic conductivity of this unit nearby in Virginia ranged from 10 to $40 \mathrm{ft} / \mathrm{d}$, and in North Carolina may range from 20 to $30 \mathrm{ft} / \mathrm{d}$.

The thickness of the Lower Cretaceous aquifer (A1) ranges from about $15 \mathrm{ft}$ near its western limit to more than 2,000 ft in Currituck County. The average thickness of the Lower Cretaceous aquifer is about $500 \mathrm{ft}$.

The Lower Cretaceous confining unit (CU1) consists of clay and sandy clay beds that are of Early Cretaceous or Late Cretaceous age. The thickness of the unit averages about $45 \mathrm{ft}$ but is nearly $70 \mathrm{ft}$ in Camden and Currituck Counties. The Lower Cretaceous aquifer and confining unit are overlain everywhere by the lower Cape Fear aquifer (A2) and are underlain everywhere by crystalline basement rocks (Winner and Coble, 1989, 1996).

\section{SIMULATION OF GROUND-WATER FLOW}

\section{EQUATION OF GROUND-WATER FLOW}

The basic equation of ground-water flow used in this report is of the form

$$
\begin{aligned}
& \frac{\partial}{\partial x}\left[T_{x x} \frac{\partial h}{\partial x}\right]+\frac{\partial}{\partial y}\left[T_{y y} \frac{\partial h}{\partial y}\right]+\frac{b \partial}{\partial z}\left[K_{z z} \frac{\partial h}{\partial z}\right]= \\
& \\
& S \frac{\partial h}{\partial t}+b W(x, y, z, t)
\end{aligned}
$$

in which, using units of time $(T)$ and length $(L)$ :

$T_{x x}=$ principal component of the transmissivity tensor in the $x$ direction $\left(L^{2} T^{-1}\right)$;

$T_{y y}=$ principal component of the transmissivity tensor in the $y$ direction $\left(L^{2} T^{-1}\right)$;

$K_{z z}=$ principal component of the hydraulic conductivity tensor in the $z$ direction $\left(L T^{-1}\right)$;

$h=$ hydraulic head $(L)$;

$S=$ storage coefficient (dimensionless);

$b=$ thickness of hydraulic unit $(L)$;

$t=$ time $(T)$;

$x, y, z=$ space coordinates $(L)$;

$W(x, y, z, t)=$ volumetric flux per unit volume $\left(T^{-1}\right)$.

The derivation of this equation will not be explained here, but discussions of its development may be found in Trescott (1975) and Trescott and Larson (1976).

\section{DIGITAL MODEL OF GROUND-WATER FLOW}

The digital model used in this study to solve a finite-difference form of the preceding ground-water flow equation (eq. 1) is described by Leahy (1982). Leahy's model is a modified version of a three-dimen- 


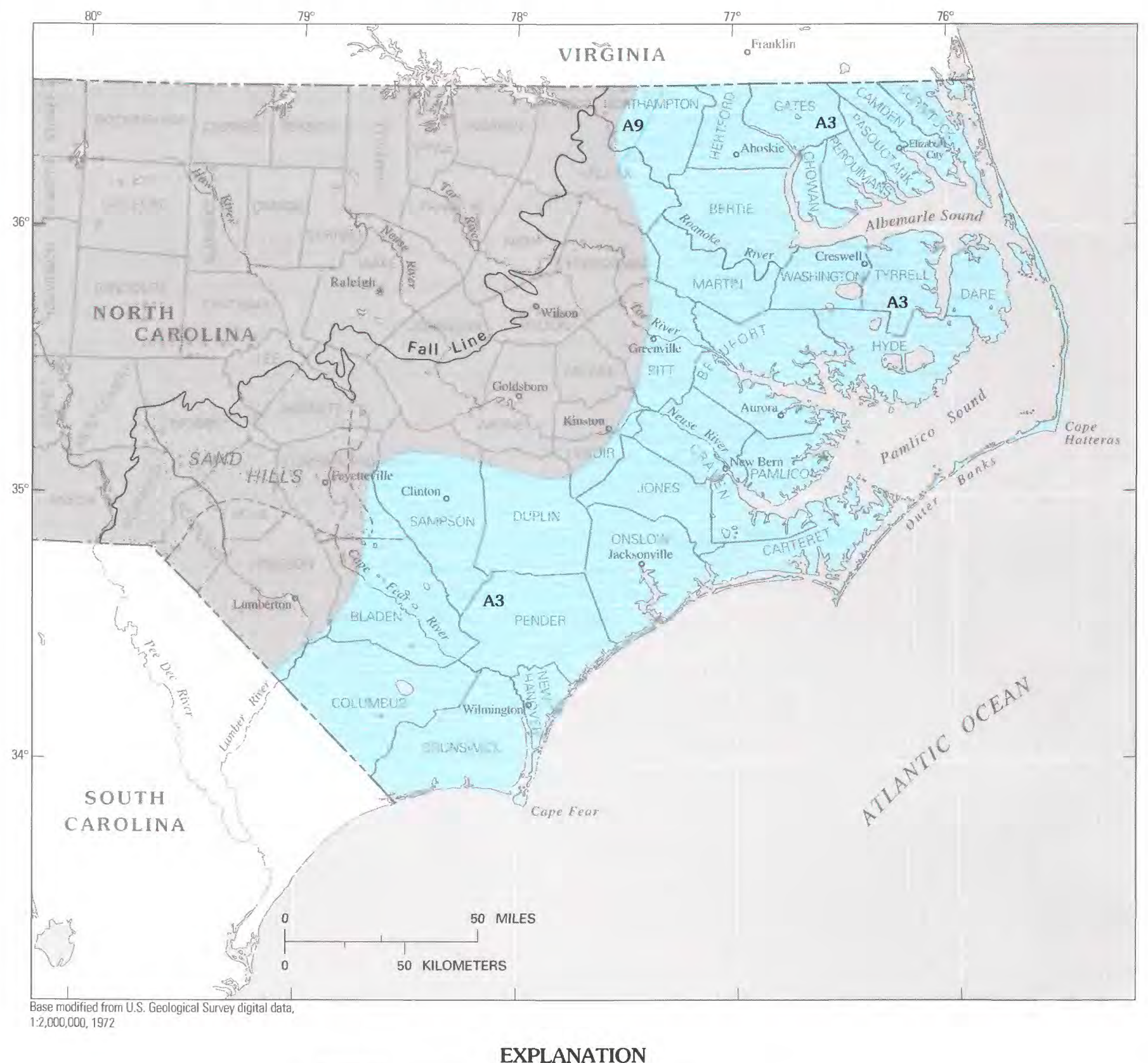

Lower Cape Fear aquifer not present

Limit and designation of aquifer and confining unit directly overlying the lower Cape Fear aquifer

A9 Yorktown aquifer and confining unit

A3 Upper Cape Fear aquifer and confining unit

FIgURE 20.-Areal extent of the lower Cape Fear aquifer (A2) and overlying aquifers (modified from Winner and Coble, 1989). 


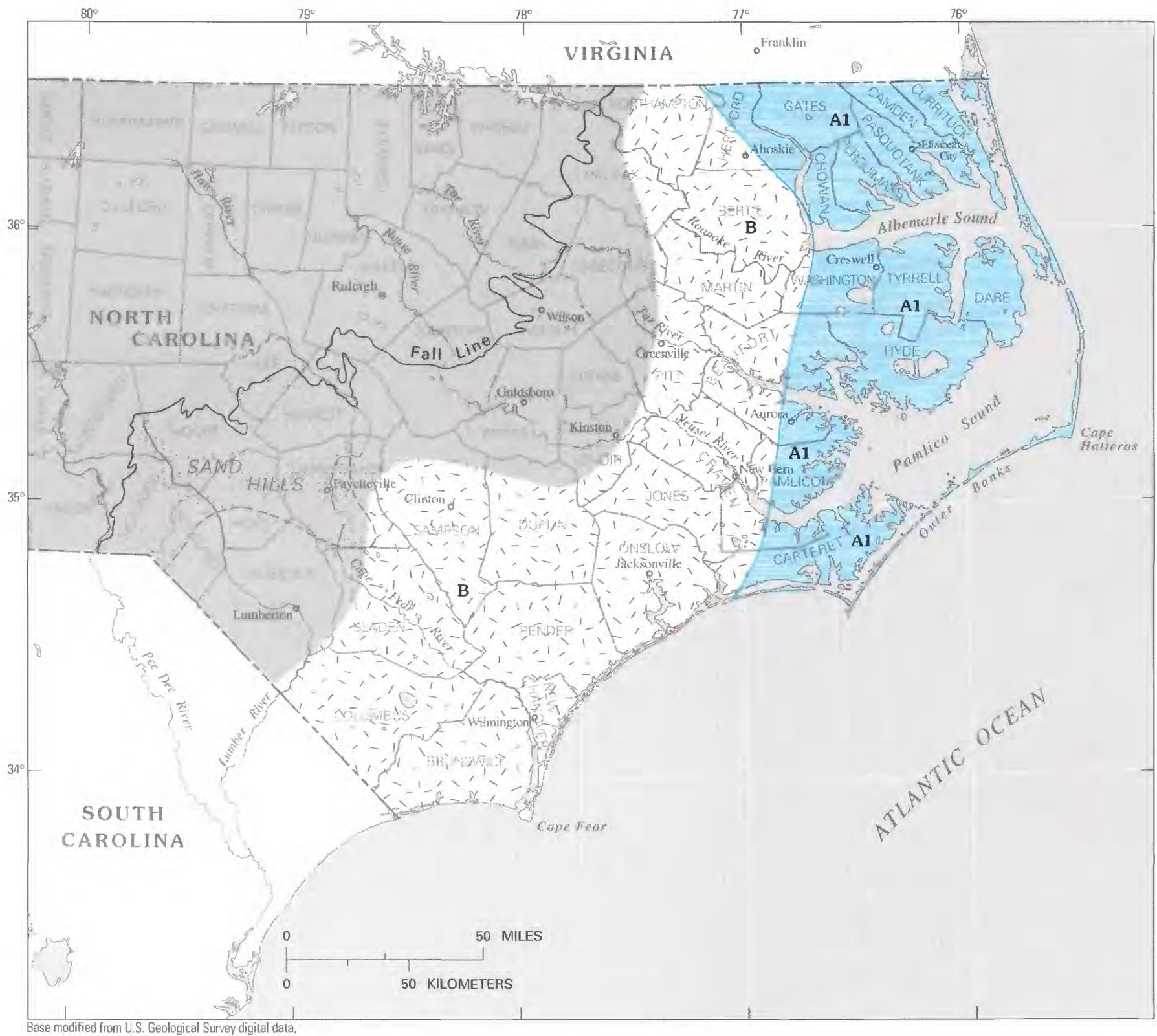

Base modified from US Geological Survey digital data $1: 2,000,000,1972$

\section{EXPLANATION}

\section{Lower Cape Fear aquifer not present}

Limit and designation of aquifer and confining unit, or basement rock, directly underlying the lower Cape Fear aquifer

A1 Lower Cretaceous aquifer and confining unit
B B Basement rock

Figure 21.-Areal extent of the lower Cape Fear aquifer (A2) and underlying aquifers or basement rock (modified from Winner and Coble, 1989). 
sional finite-difference flow model program described by Trescott (1975) and Trescott and Larson (1976). The model assumes that all flow in the aquifers is horizontal and all flow in the confining units is vertical. Leahy's modification reduces computer-memory requirements and better simulates confining-unit and aquifer pinchouts.

\section{GRID DESIGN}

The model area is divided into a rectangular grid having 11 layers, 60 rows, and 48 columns. The grid spacing is variable. The smallest rectangle is $12.25 \mathrm{mi}^{2}$ and the largest is $56.25 \mathrm{mi}^{2}$ (fig. 22). This grid is designed to be compatible with the regional model grid described by Leahy and Martin (1993) intended for simulating the entire Northern Atlantic Coastal Plain aquifer system, in that each rectangle of the regional grid is divided into four small, local (North Carolina) grids.

Each layer of the North Carolina model has 2,880 rectangular blocks, which total 31,680 blocks for the 11 layers. The model nodes are located at the center of each block. Each input value assigned to a node is considered to be an average value for the entire block. Likewise, output values (hydraulic head and drawdown) are also average values for that block. An assumption inherent in this approach is that the Cartesian coordinate axes $x$ and $y$ are aligned with the principal components of the transmissivity tensor $T_{x x}$ and $T_{y y}$.

\section{MODEL BOUNDARIES}

The confined aquifers (A9-A1) thin to extinction at their westernmost limit. Therefore, the westernmost limit of each aquifer is treated as a no-flow boundary. The westernmost limit of the surficial aquifer (A10) coincides with the westernmost limit of the North Carolina Coastal Plain study area and is also treated as a no-flow boundary.

The eastern limit of the fresh ground-water flow system is assumed to be at an equal concentration line where the water contains $10,000 \mathrm{mg} / \mathrm{L}$ of chloride, and the line is also treated as a no-flow boundary. The place where this concentration line occurs in each aquifer within the model area is referred to as the freshwater-saltwater boundary. It is important to note that this assumption is considered valid only in areas where there are negligible drawdowns due to pumping at or near the freshwater-saltwater boundaries. Where a layer's freshwater-saltwater boundary occurs outside the model area, the eastern model boundary for that layer is a specified-flux boundary, the fluxes being supplied by the regional model. In this report, the eastern limits of the aquifers are shown only if they occur on land, although the aquifers were actually modeled to their freshwatersaltwater boundaries or to the boundary of the model. The upper boundary of each confined aquifer is the bottom of its associated confining unit and is treated in the model algorithm as if it were a head-dependent flux boundary.

The bottom boundary of each aquifer is either a head-dependent flux boundary (where another aquifer and confining unit are present below) or a no-flow boundary (where bedrock or a freshwater-saltwater boundary underlie the aquifer). Where the modeled area of an aquifer is bounded by the Virginia or South Carolina State borders, these borders are treated as specified-flux boundaries to simulate the movement of water across the State lines. Again, the fluxes are supplied from the regional model and simulate not only natural flow, but also induced flow due to the effects of pumping inside and outside the North Carolina study area. The uppermost active model node at any location represents a stream- or lake-surface elevation and is treated as a constant-head node; the lowermost active node at any given location represents a freshwater-saltwater boundary or bedrock and is treated as a no-flow boundary.

\section{MODEL INPUT}

The following sections discuss how aspects of the conceptual model of the aquifer system were represented numerically in the input requirements for the flow model. The model input requirements are shown schematically in figure 23. Printouts of model input for the calibrated model are available from the U.S. Geological Survey, P.O. Box 30728, Raleigh, NC 27607. Many of the items discussed under "Model Input" also relate to the water-budget aspect of the conceptual model of the aquifer system (fig. 3).

\section{GROUND-WATER RECHARGE}

On a nodal basis, recharge to the surficial aquifer (A10) was estimated to range between 12 and $20 \mathrm{in} / \mathrm{yr}$ over the North Carolina Coastal Plain and to average nearly $14 \mathrm{in}$. Each water-table node was given a recharge value of $12,14,16$, or $20 \mathrm{in} / \mathrm{yr}$, based on (1) soil characteristics from U.S. Soil Conservation Service maps (Tant and others, 1974), (2) estimates of recharge to thick sandy soils by Heath (1980), and (3) estimates of base flow to the North Carolina Coastal Plain streams from hydrograph separation using techniques developed by Rorabaugh (1964) and Daniel (1976), as described by Wilder and Simmons (1982). Maximum recharge rates (fig. 24) occur in the Sand Hills area, and minimum rates 


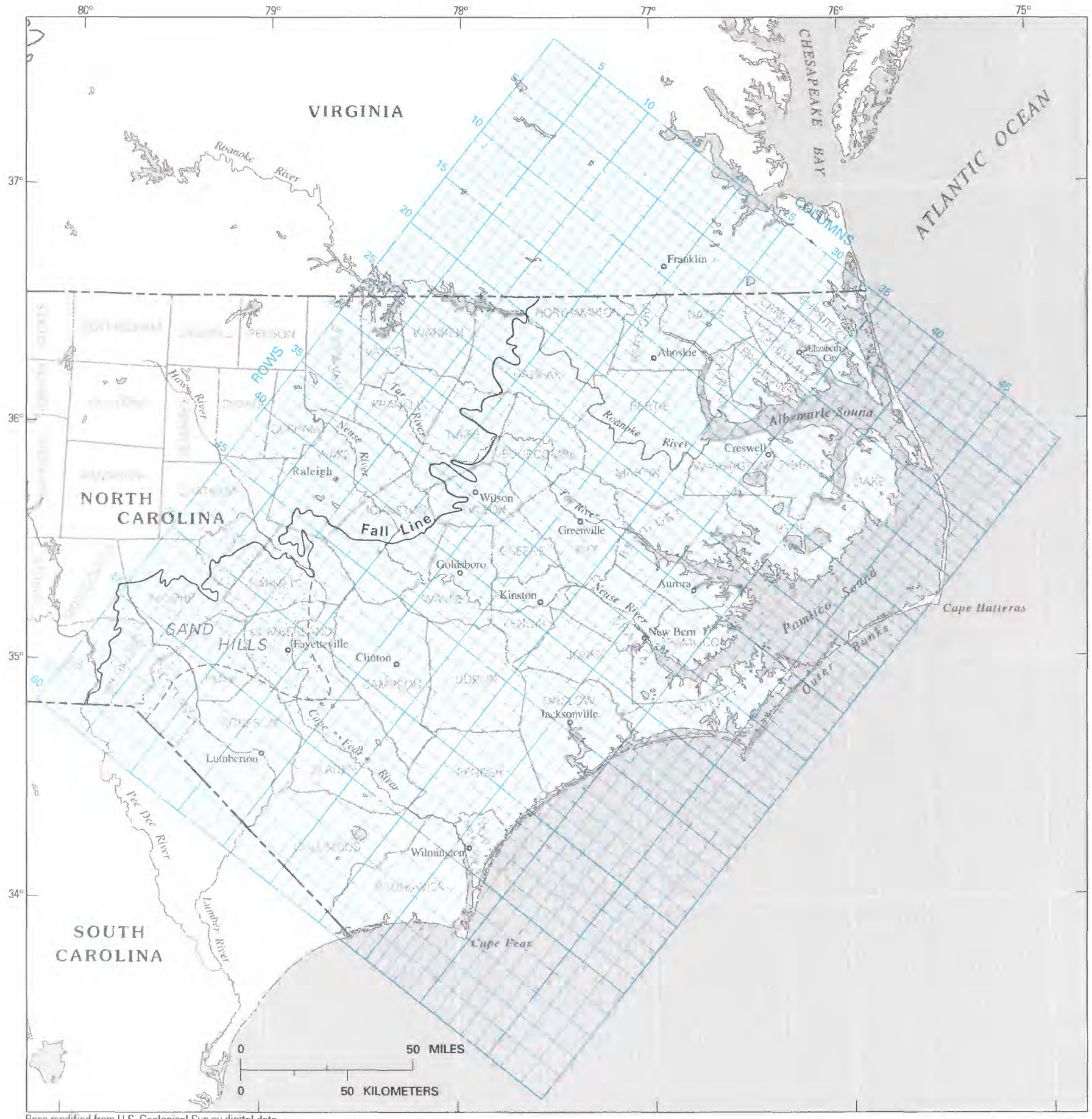

Base modified from U.S. Geological Survey digital data, 1:2,000,000, 1972

Figure 22.-Finite-difference grid for the flow model of the North Carolina Coastal Plain aquifer system. 


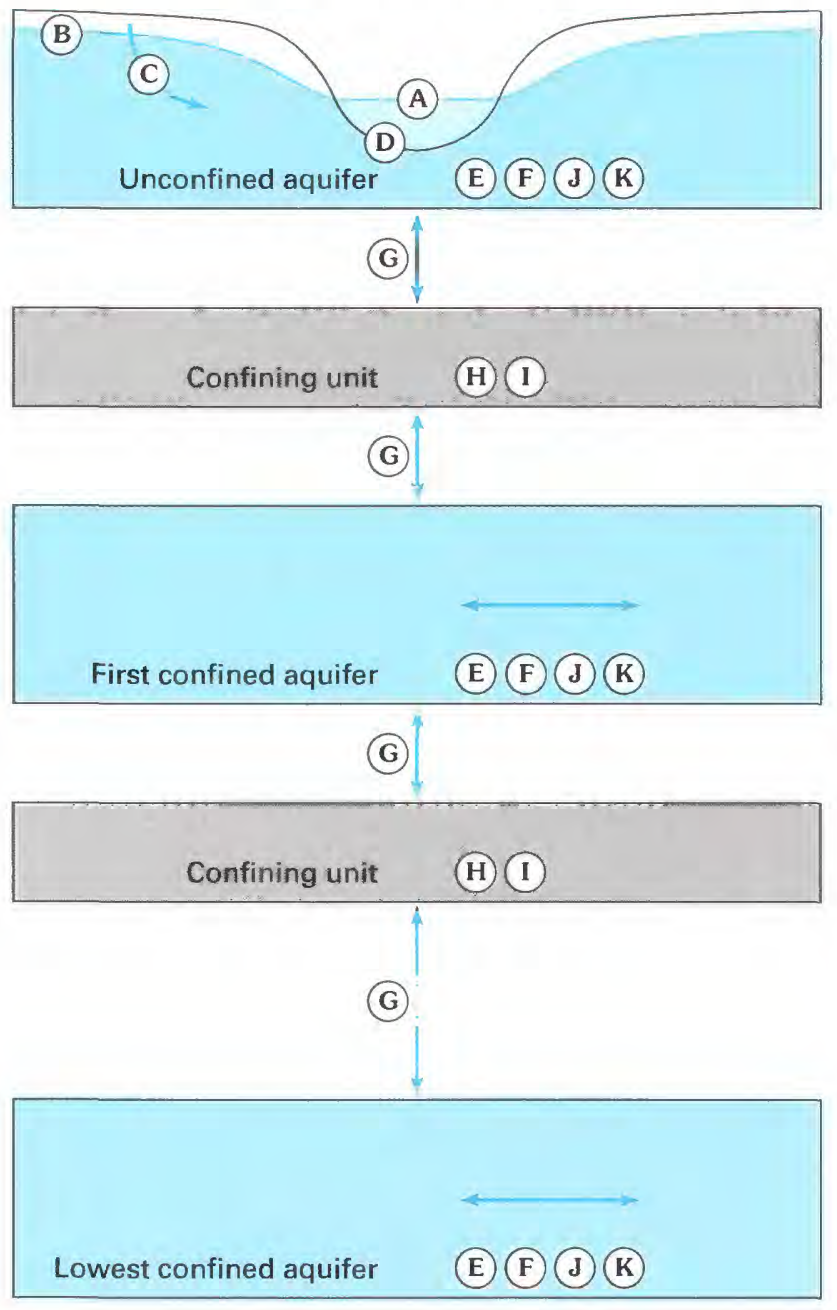

Model input requirements

A Stream-surface or lake-surface altitude

(B) Water-table altitude

(C) Recharge to water table (QRE)

(D) Stream channel leakance (TK)

(E) Transmissivity of aquifer ( $T$ )

(F) Specific yield or storage coefficient of aquifer (S)

(G) Deep percolation (DP)

(H) Effective thickness of confining unit (b)

(I) Vertical hydraulic conductivity of confining unit $\left(K_{v}\right)$

(J) Water-level data required for calibration

(K) Ground-water pumpage

\section{Flow direction}

FIGURE 23.-Schematic representation of model input requirements. occur generally in the east, where surficial soils have a high clay content.

\section{STREAMBED LEAKANCE}

The exchange of water between the surficial aquifer and a stream through the streambed can be expressed for steady-state conditions and on a unit-area basis by the following equation, which is an expression of Darcy's law:

$$
B F=S L\left(h_{a}-h_{s}\right)
$$

where

$B F=$ stream base flow (ground-water contribution to streamflow), in cubic feet per day per square foot $\left[\left(\mathrm{ft}^{3} / \mathrm{d}\right) / \mathrm{ft}^{2}\right]$;

$S L=$ streambed leakance factor, computed as the ratio of the vertical hydraulic conductivity $\left(K_{v}\right)$ of the streambed material, in $\left(\mathrm{ft}^{3} / \mathrm{d}\right) / \mathrm{ft}^{2}$, or $\mathrm{ft} / \mathrm{d}$, to the thickness of the streambed material $(b)$, in feet, yielding units of $(\mathrm{ft} / \mathrm{d}) / \mathrm{ft}$, or per day;

$h_{a}=$ estimated altitude of water table in the surficial aquifer, in feet;

$h_{s}=$ estimated altitude of stream surface, in feet.

The average water-table altitude and lowest stream altitude within each appropriate block were estimated from U.S. Geological Survey topographic maps at scales of $1: 24,000$ and $1: 62,250$. The lowest stream altitude for each block was chosen because it was considered the "controlling" elevation governing flow from the surficial aquifer (A10) to the stream system. Base flow was determined from the following equation, which is for steadystate conditions:

$$
B F=Q R E \pm D P
$$

where

$B F=$ stream base flow, in cubic feet per day per square foot;

$Q R E=$ ground-water recharge to the surficial aquifer, in feet per second;

$D P=$ deep percolation into or flow out of the underlying confined aquifer system, in feet per day.

Ground-water recharge $(Q R E)$ was determined for and input into each block, as described above in the "Ground-Water Recharge" section of this report. Deep percolation $(D P)$ was calculated for each block from simulations for predevelopment steady-state conditions in which the water table was treated as a constant-head boundary. Average base flow for each block could then be calculated from equation 3 above, and the resulting base-flow value substituted into equation 2 to solve for streambed leakance $(S L)$. A constant-head value equal to 


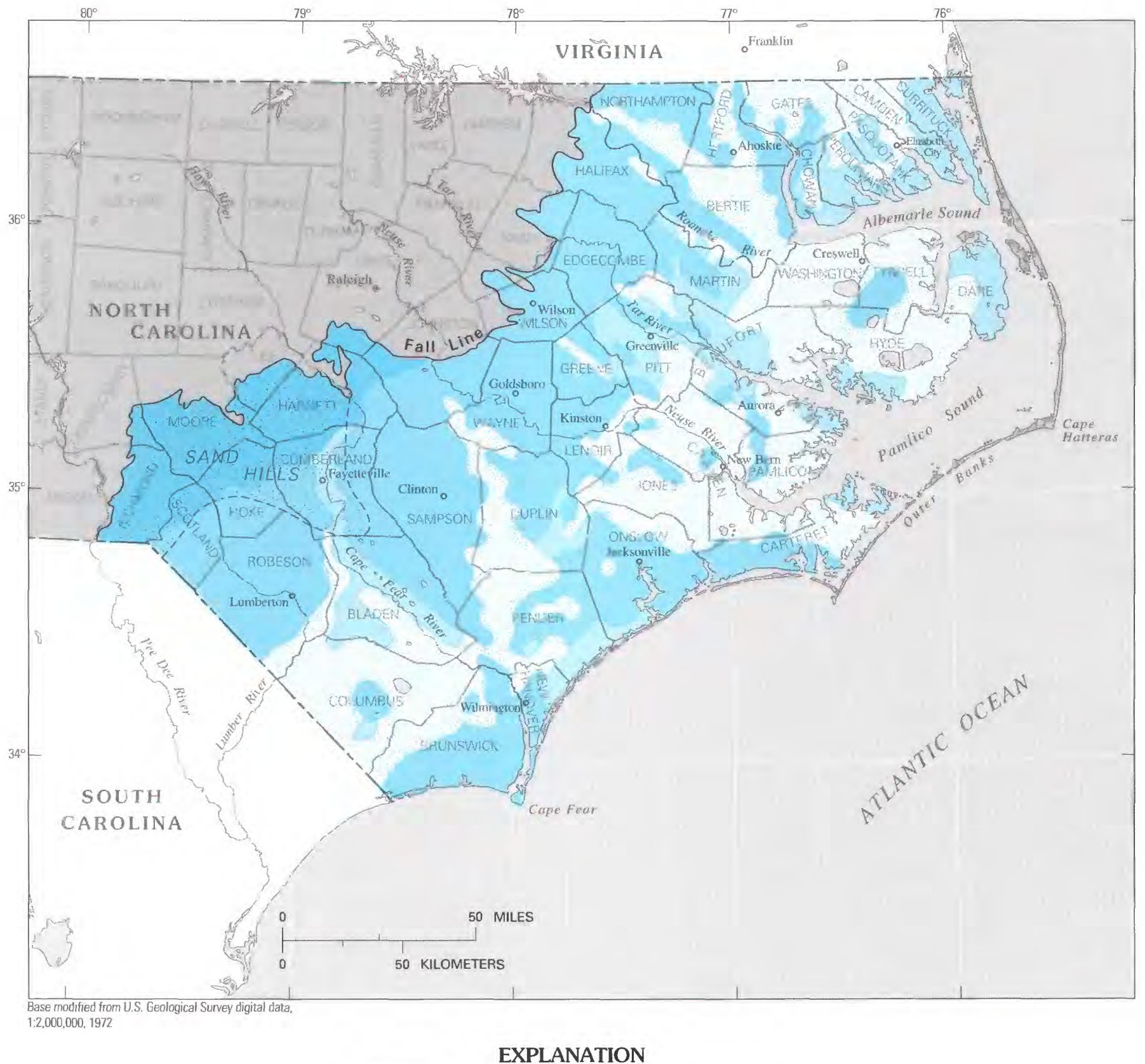

Area where recharge was not estimated

Area of estimated recharge

Recharge 12 inches per year

Recharge 14 inches per year

Recharge 16 inches per year

Recharge 20 inches per year

FIGURE 24-Estimated recharge to surficial aquifer (A10) from precipitation (modified from Winner and Coble, 1989). 
the stream altitude value was then assigned to each node overlying the water table. This procedure allowed fairly realistic simulation of water-table behavior during transient simulations. For example, as the water table is drawn down due to pumping from a confined aquifer below, base flow to streams is reduced; if the water table is drawn down below stream level, induced infiltration takes place, and the stream "recharges" the surficial aquifer.

The mechanics of simulations involving streams and streambed leakance are discussed in more detail in the "Model Calibration" section of this report; the important points here are the mechanics of calculating streambed leakance and the recognition that the streambed leakances are not reflective of leakances of real streambeds, but represent an "effective" streambed for an entire block. Thus, "model" streambed leakances (fig. 25) are much less than "real" streambed leakances. The distribution of streambed leakance values used as model input is shown in figure 25.

\section{TRANSMISSIVITY OF AQUIFERS}

Transmissivity ( $T$ ) is equal to $K_{h} b$, where $K_{h}$ is the horizontal hydraulic conductivity of the aquifer and $b$ is the thickness of the aquifer. The model employs the units of feet squared per second for transmissivity, but it is reported in units of feet squared per day ( $\left.\mathrm{ft}^{2} / \mathrm{d}\right)$ in the text and figures.

Initial estimates of transmissivity for model input were determined primarily from examination of geophysical logs. The character of the permeable material within each aquifer was interpreted from the logs, and a horizontal hydraulic conductivity $\left(K_{h}\right)$ value of the aquifer material was assigned to the unit, roughly according to guidelines given in Morris and Johnson (1967, table 5). Average values of $K_{h}$ determined in this manner ranged from $22 \mathrm{ft} / \mathrm{d}$ in the Yorktown aquifer (A9) to $65 \mathrm{ft} / \mathrm{d}$ in the Castle Hayne aquifer (A7) (Winner and Coble, 1989, 1996). The hydraulic conductivity was then multiplied by the thickness of permeable material within each aquifer to arrive at a transmissivity value. Clay and silt layers were not included as part of aquifer thickness in computing $T$. The character of the permeable material was verified from geologists' logs where available. Where available and appropriate, existing aquifer-test data were used to confirm the transmissivity values.

Maps showing transmissivity used in model simulation after calibration for aquifers $\mathrm{A} 9$ through $\mathrm{A} 1$ are shown in figures 26 through 34 . Transmissivities diminish to zero at the western limits of all units except the surficial aquifer (A10). Maximum transmissivities of slightly more than $175,000 \mathrm{ft}^{2} / \mathrm{d}$ occur in the Castle Hayne aquifer (A7) (fig. 28). Maximum $T$ values in other aquifers seldom exceeded $10,000 \mathrm{ft}^{2} / \mathrm{d}$. The rationale for varying transmissivity during the calibration process is discussed under "Model Calibration."

\section{StORAGE CoefFicient OF AQuifers}

In this study, a storage coefficient value of $1 \times 10^{-4}$ was assigned to all active nodes in confined aquifers; for unconfined conditions, values ranging from $1 \times 10^{-1}$ to $1.5 \times 10^{-1}$ were used. Results from aquifer tests in the North Carolina Coastal Plain indicate that $1 \times 10^{-4}$ is of the correct order of magnitude for a storage coefficient value for a confined aquifer.

\section{LEAKANCE OF CONFINING UNITS}

In the model used for this study, confining units were not represented as separate layers. Rather, the effects of vertical flow through confining units were incorporated in the vertical components of flow in the adjacent aquifers by use of a leakance term $(T K)$ defined as the ratio of $K_{v} / b$ for each confining unit, where $K_{v}$ is the vertical hydraulic conductivity of the confining unit and $b$ is its effective thickness.

The effective thickness of confining units was commonly less than the total thickness because most confining units contain thin layers of permeable material. The thickness of permeable layers within each confining unit was subtracted from the total confining-unit thickness to arrive at an effective thickness. Winner and Coble (1989) gave an effective thickness for each confining unit identified in the North Carolina Coastal Plain.

As previously mentioned, the model assumes all flow in aquifers to be horizontal and all flow in confining units to be vertical. It was recognized, however, that in many places within zones designated as aquifer material, the thickness of clay is significant, and this clay often functions as an impediment to vertical flow. A more realistic simulation of the flow system was obtained by incorporating the effects of clay within aquifers into the leakance terms. Accordingly, total effective thickness (b) values for each confining unit were generated (figs. 35-43), which represented the sum of (1) effective confining-unit thickness, (2) one-half the thickness of clay beds in the aquifer above the confining unit, and (3) one-half the thickness of clay beds in the aquifer below the confining unit. At some locations shown in figures 35 through 43, where the confining unit is designated as not present (particularly in stream valleys), the clay-within-aquifers concept was used to assign an effective clay thickness for modeling purposes.

Text continues on p. M54. 


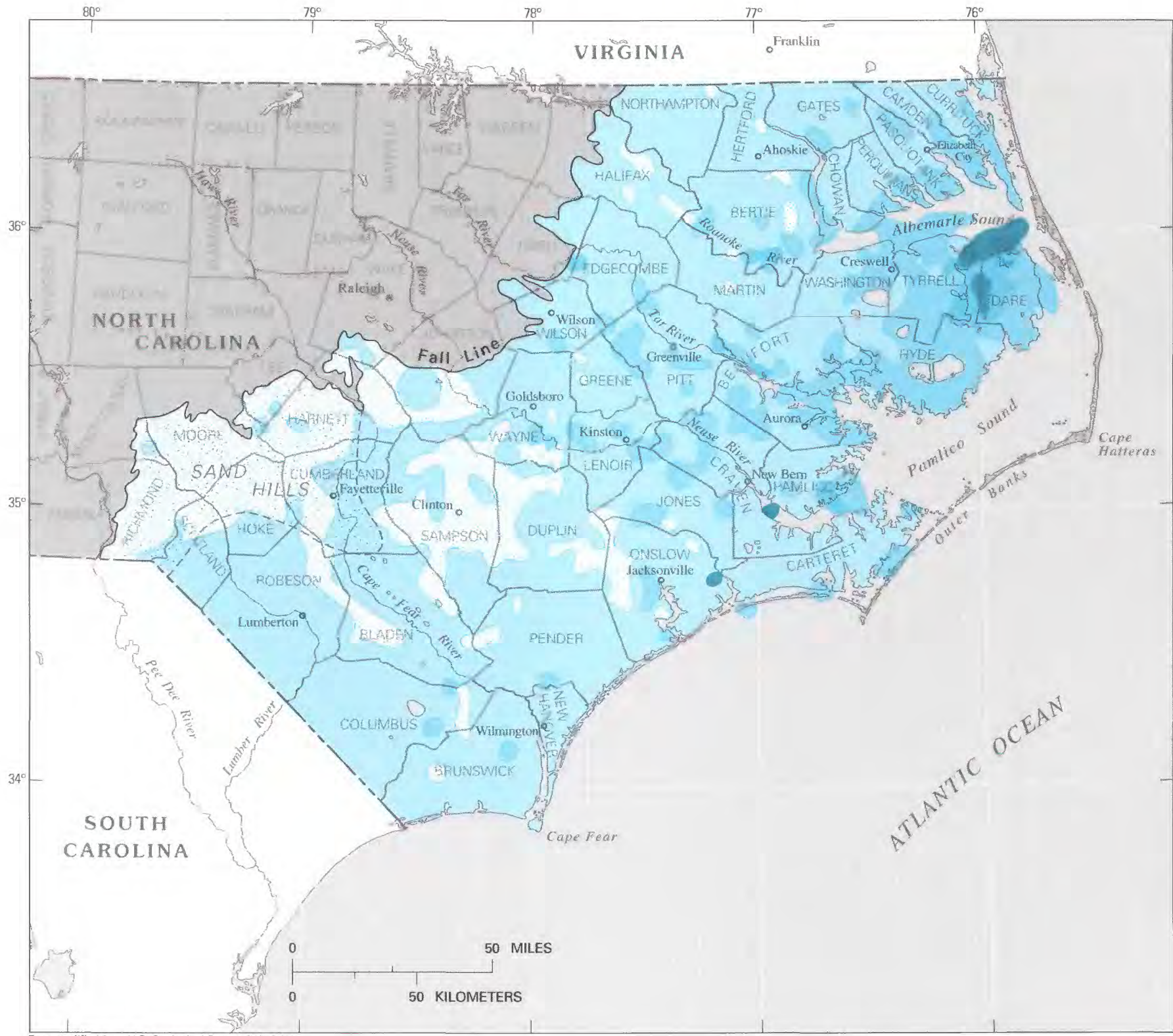

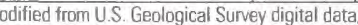

\section{EXPLANATION}

Area where streambed leakance was not determined

Streambed leakance, per day

\begin{tabular}{|l|l|}
\hline Less than 0.00001 \\
0.00001 to 0.00009 \\
0.0001 to 0.0004 \\
0.0005 to 0.0025 \\
More than 0.0025
\end{tabular}




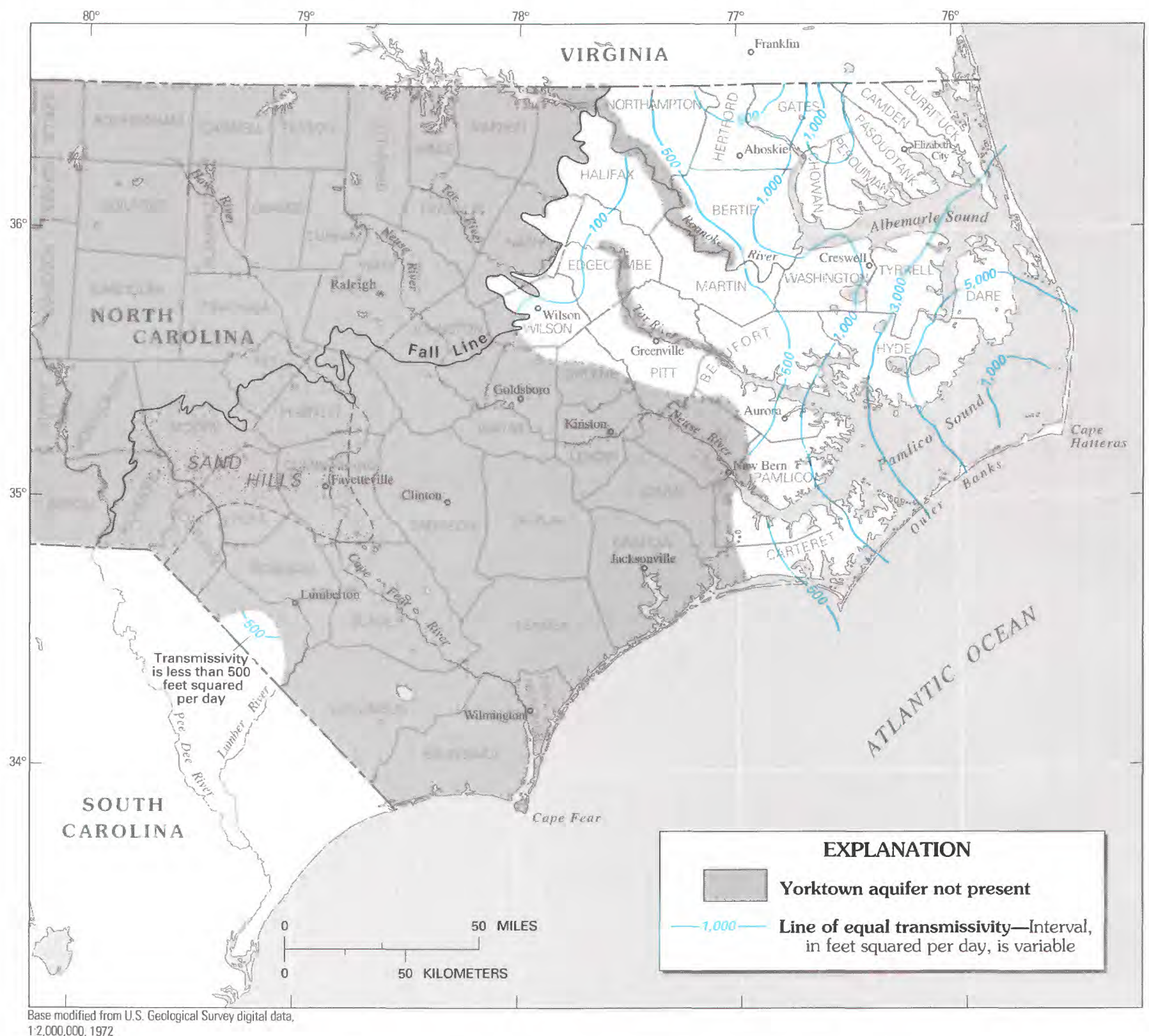

FIGURE 26.-Transmissivity of the Yorktown aquifer (A9) used in model simulations. 


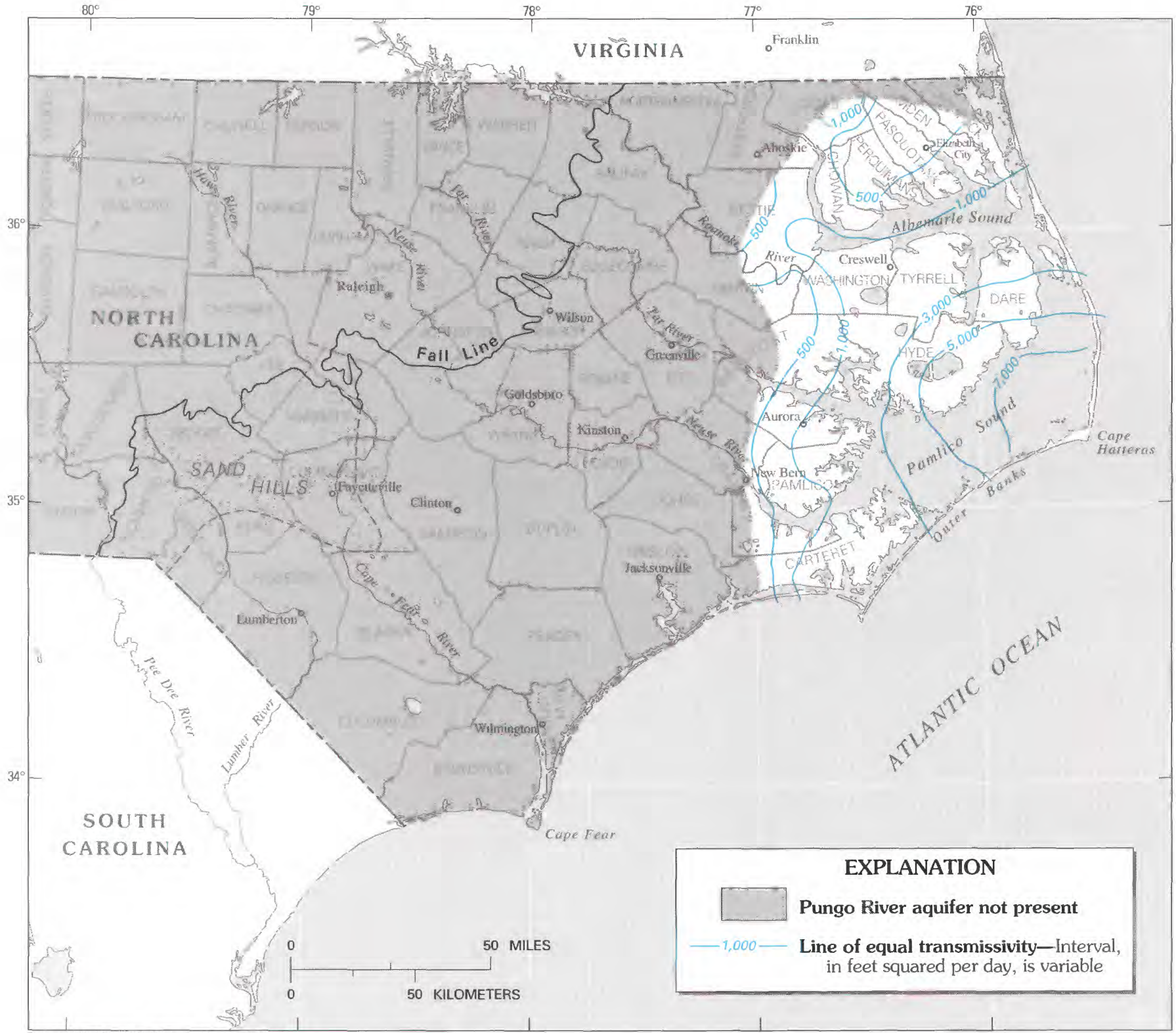

Base modified from U.S. Geological Survey digital data,

Figure 27.-Transmissivity of the Pungo River aquifer (A8) used in model simulations. 


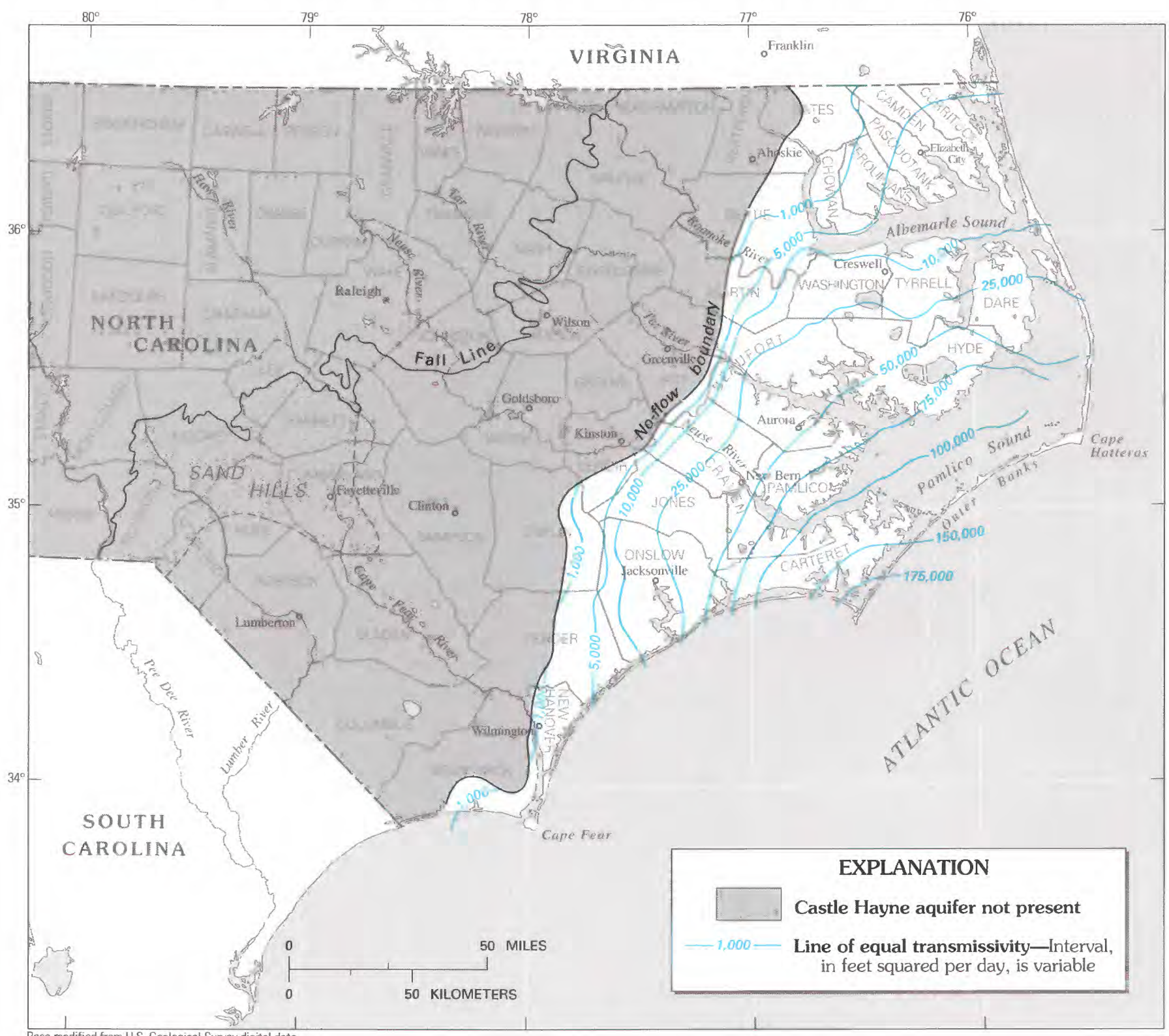

Base modified from U.S. Geological Survey digital data. 1:2,000,000, 1972

Figure 28.-Transmissivity of the Castle Hayne aquifer (A7) used in model simulations. 


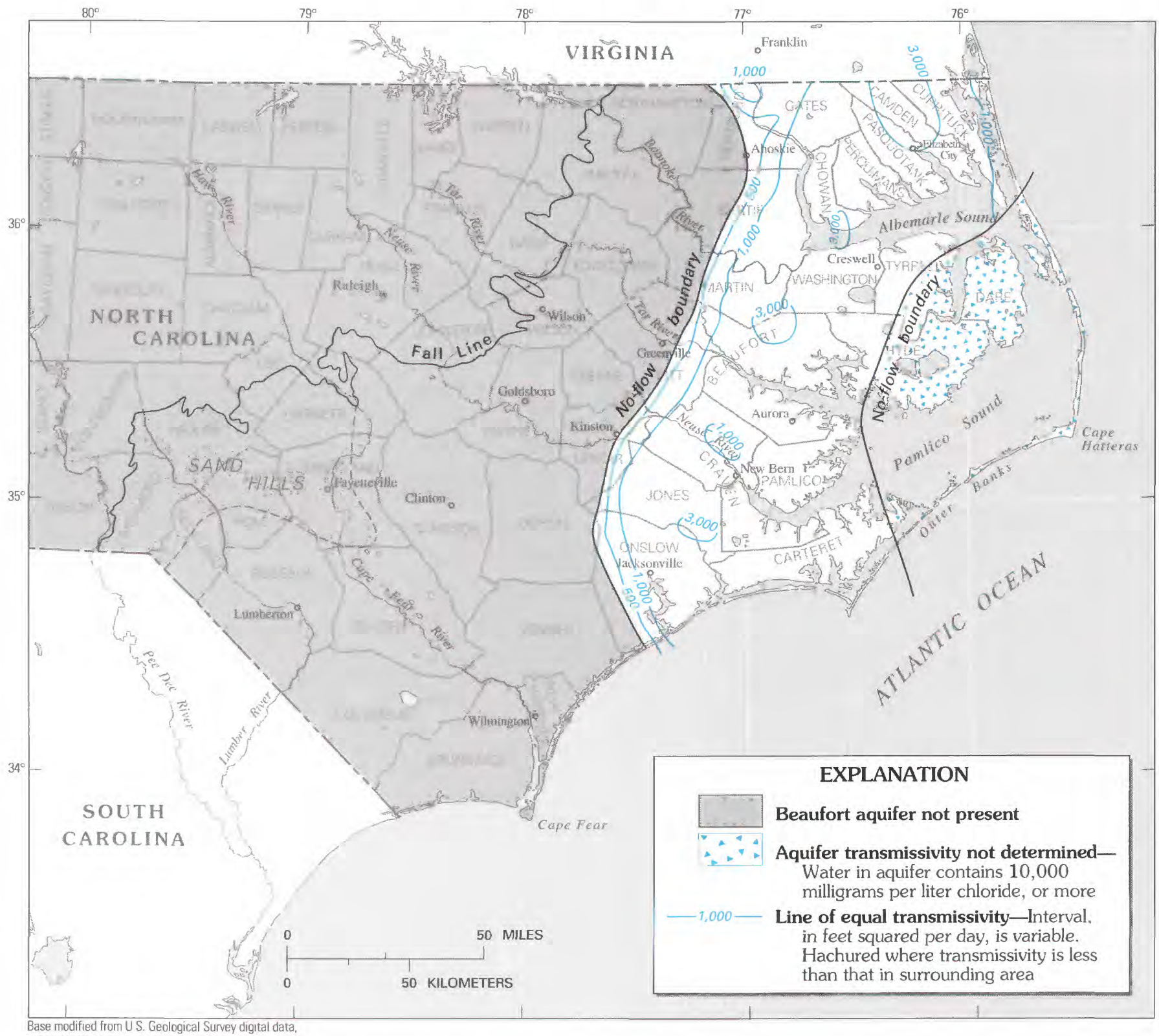

Gase modited hom US. Geological Survey dighta data,

Figure 29.-Transmissivity of the Beaufort aquifer (A6) used in model simulations. 


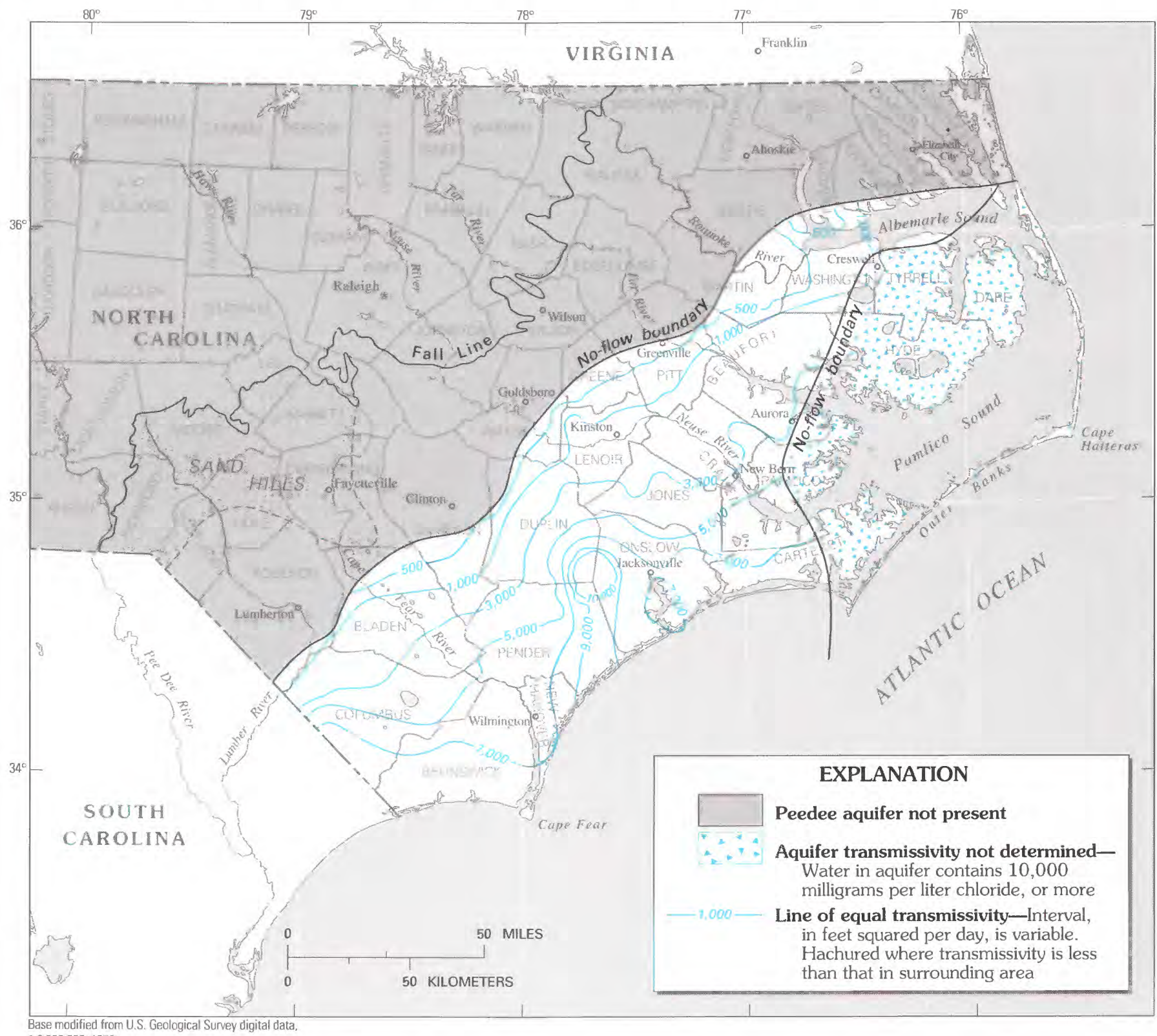

Figure 30.-Transmissivity of the Peedee aquifer (A5) used in model simulations. 


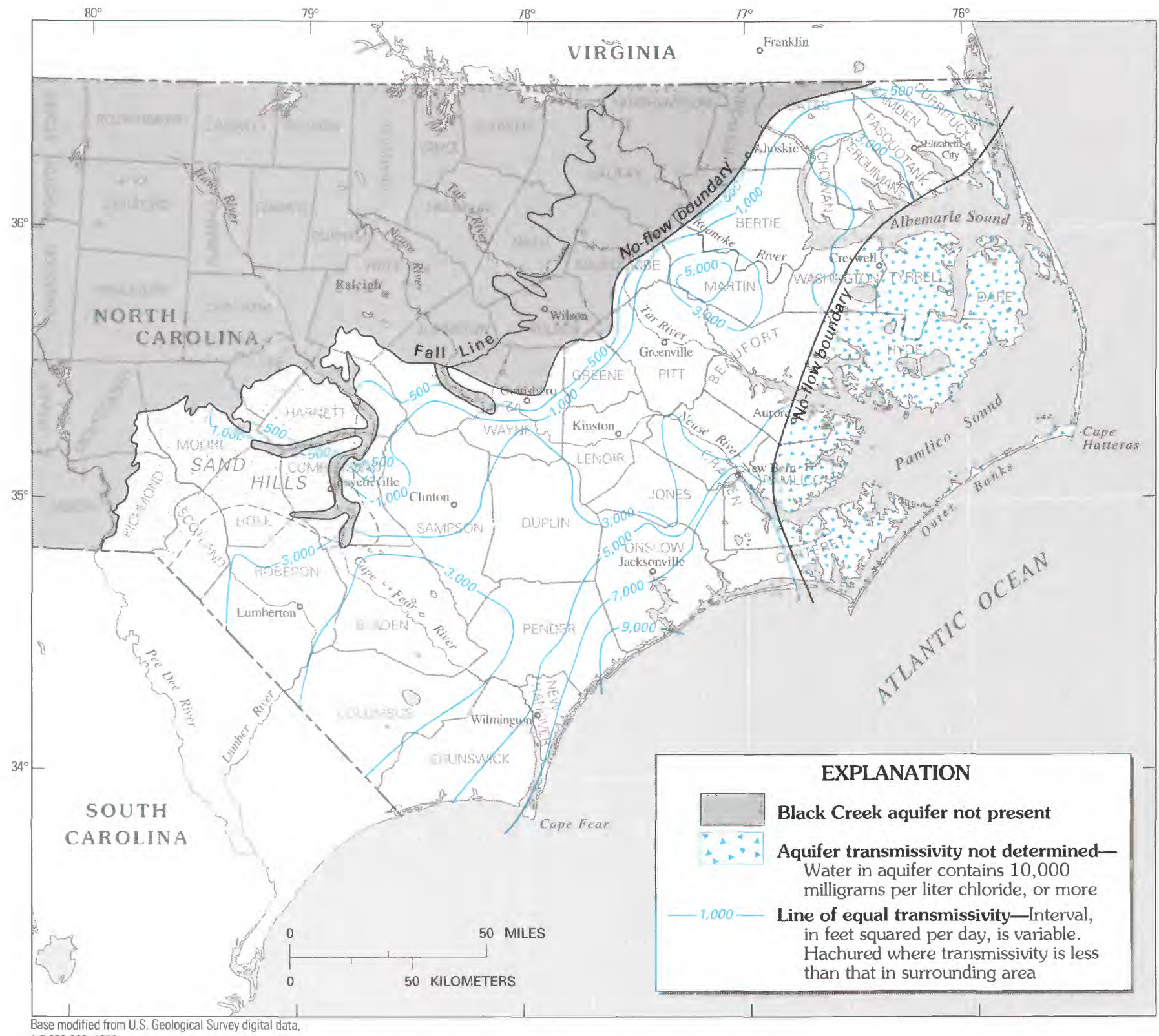

Figure 31.-Transmissivity of the Black Creek aquifer (A4) used in model simulations. 


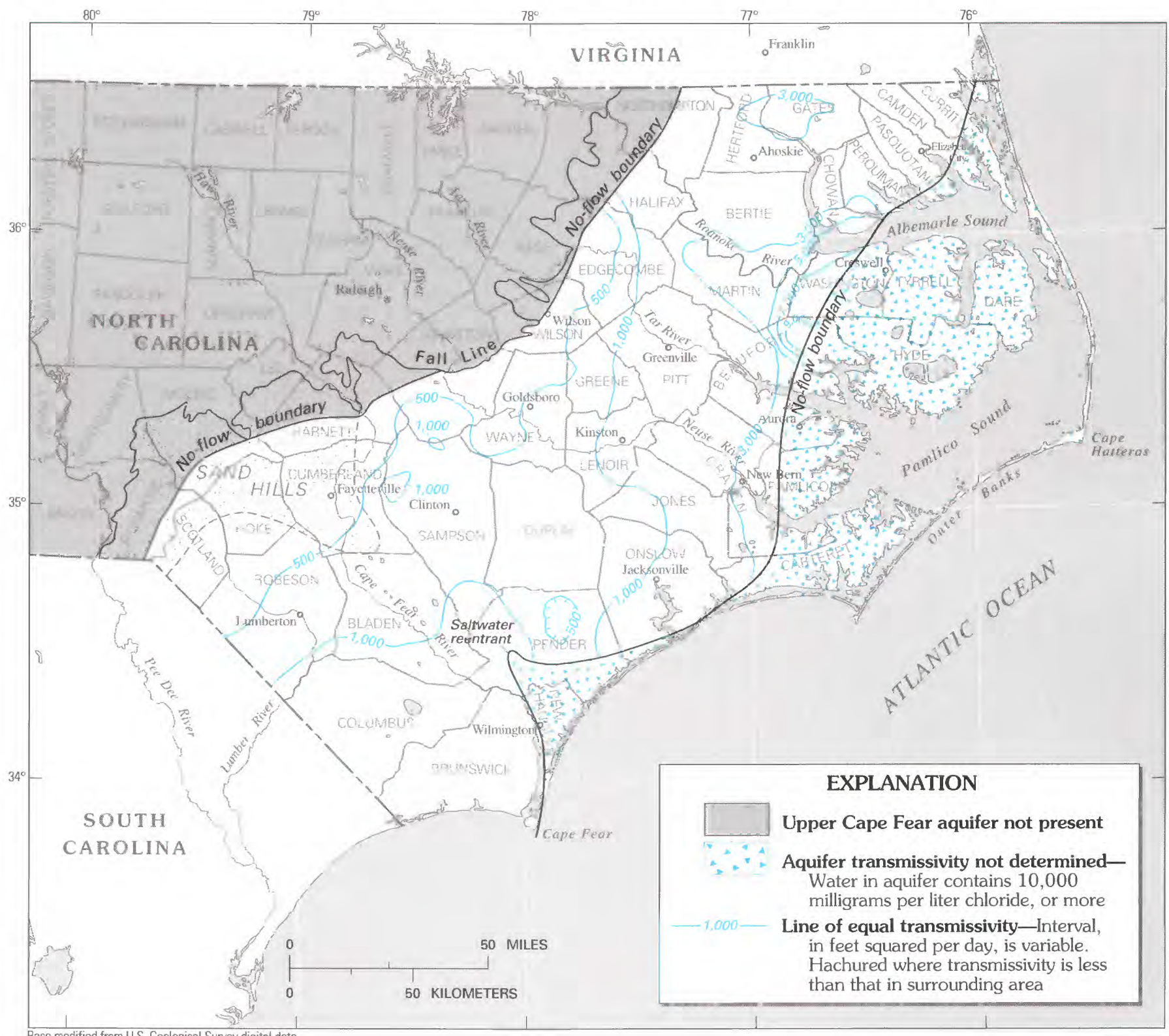

Base modified from U.S Geological Surver digital data.

Figure 32.-Transmissivity of the upper Cape Fear aquifer (A3) used in model simulations. 


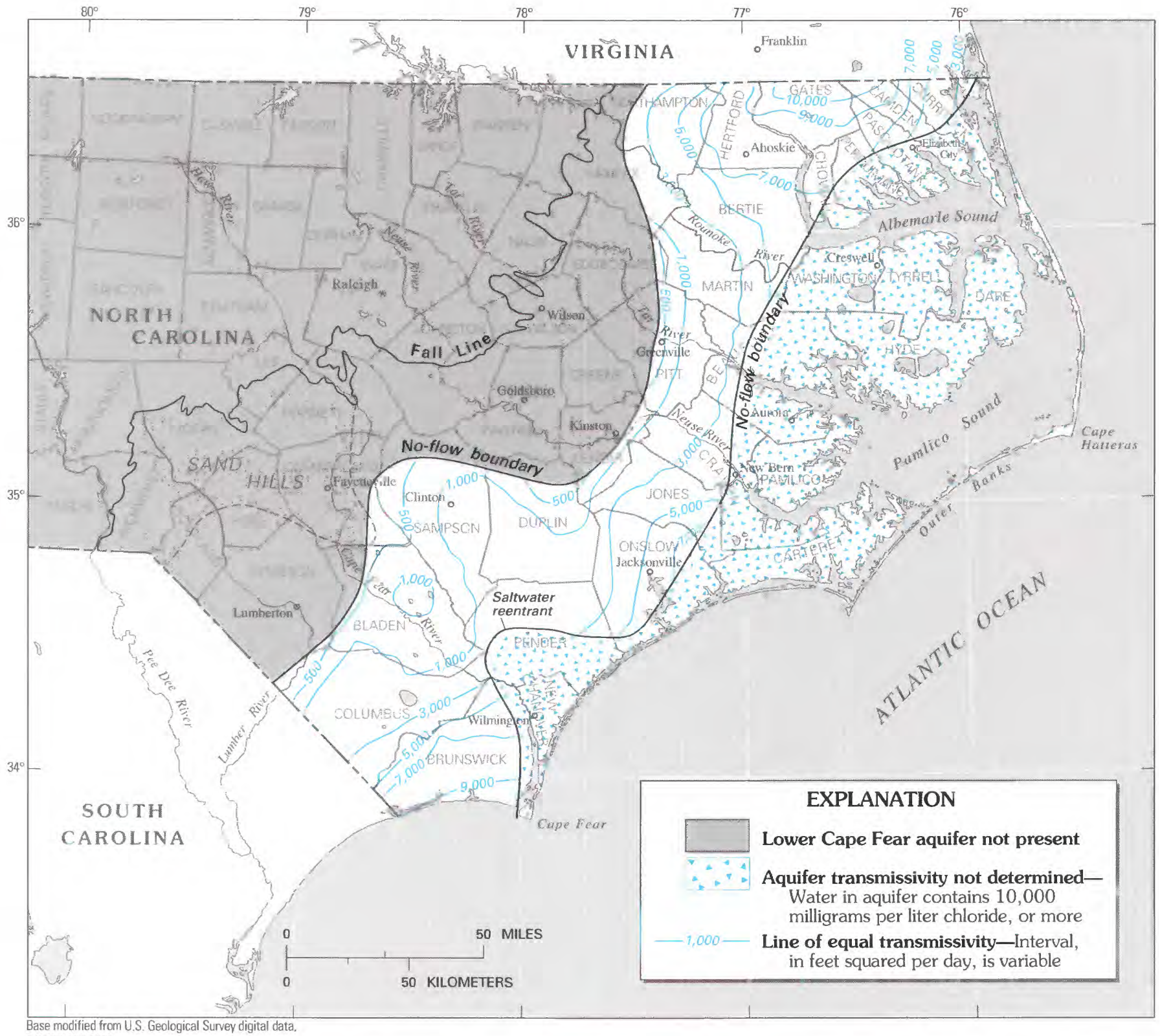

Base moditied from U.S. Geological Survey digital dat.

FigURE 33.-Transmissivity of the lower Cape Fear aquifer (A2) used in model simulations. 


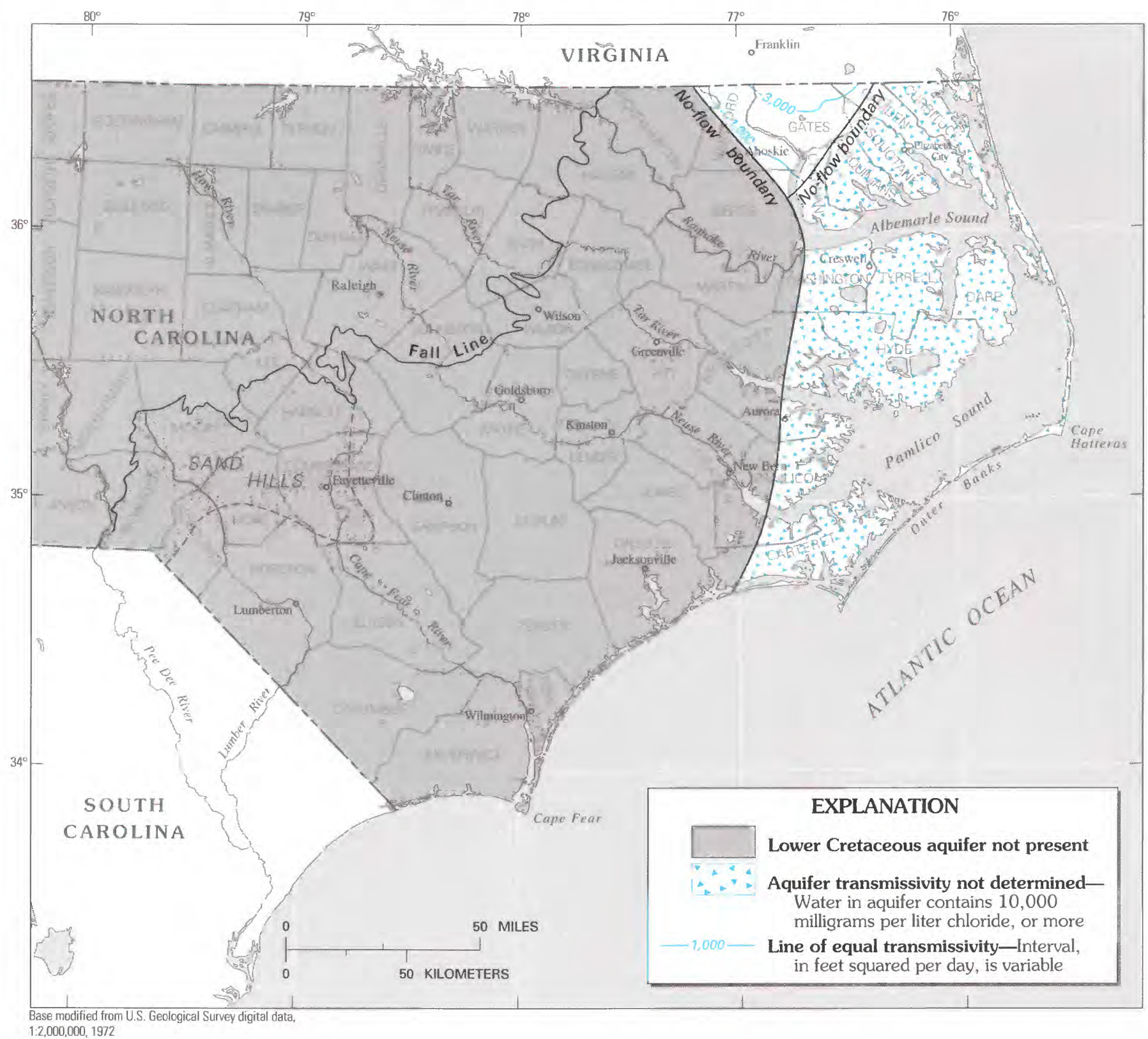

FigURE 34.--Transmissivity of the Lower Cretaceous aquifer (A1) used in model simulations. 


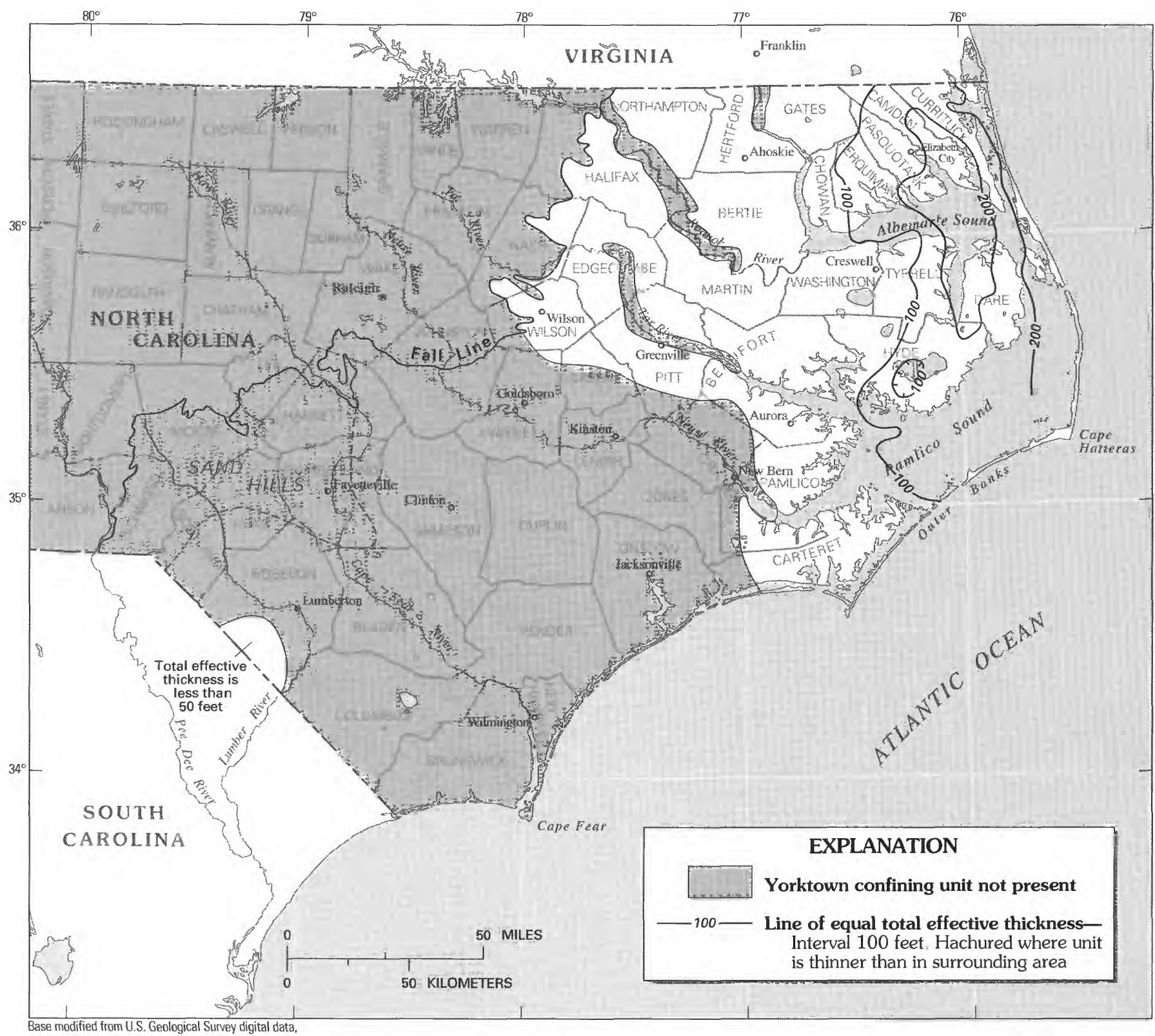

FIGURE 35-Total effective thickness of the Yorktown confining unit (CU9). 


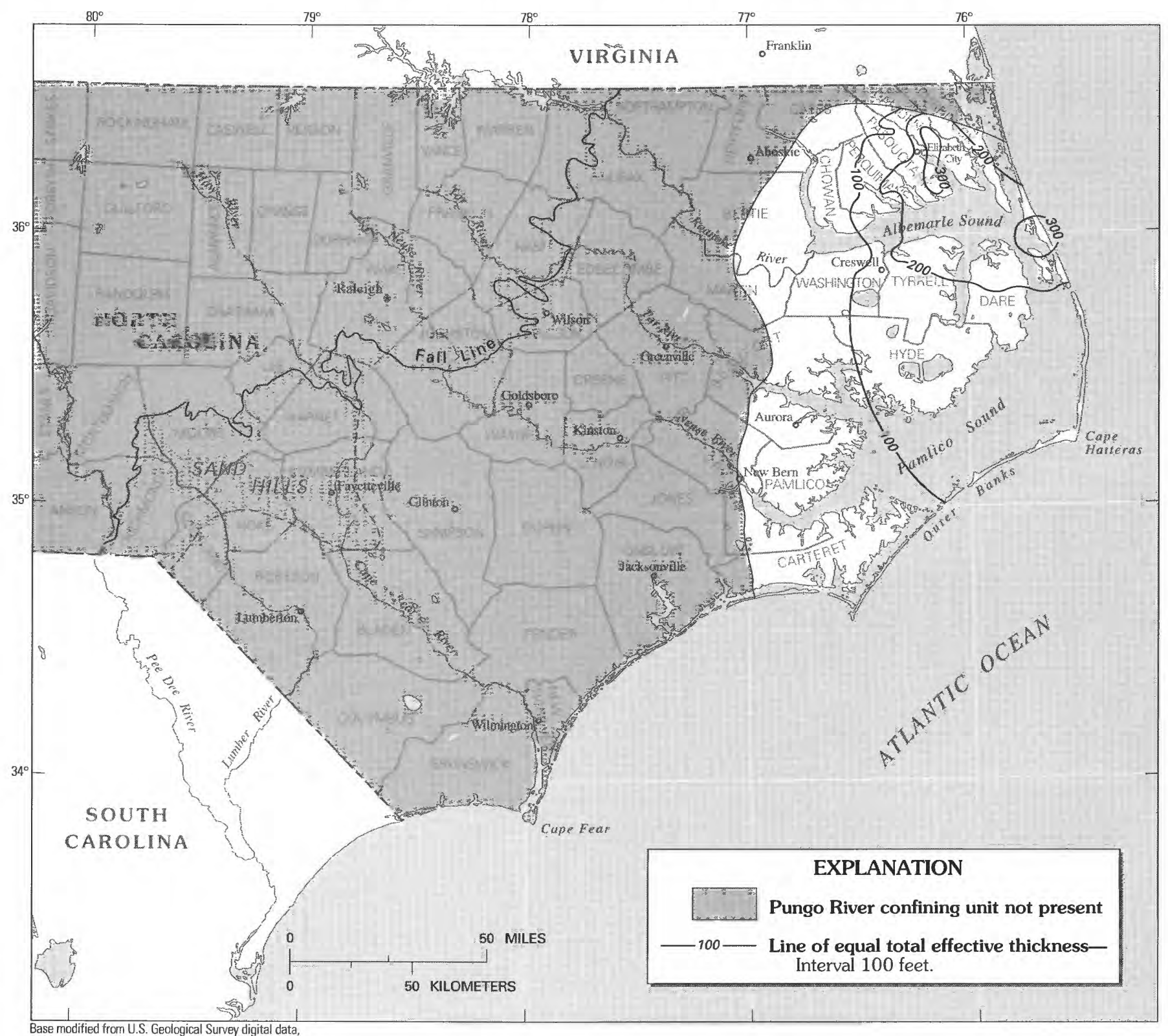

FiguRE 36.-Total effective thickness of the Pungo River confining unit (CU8). 


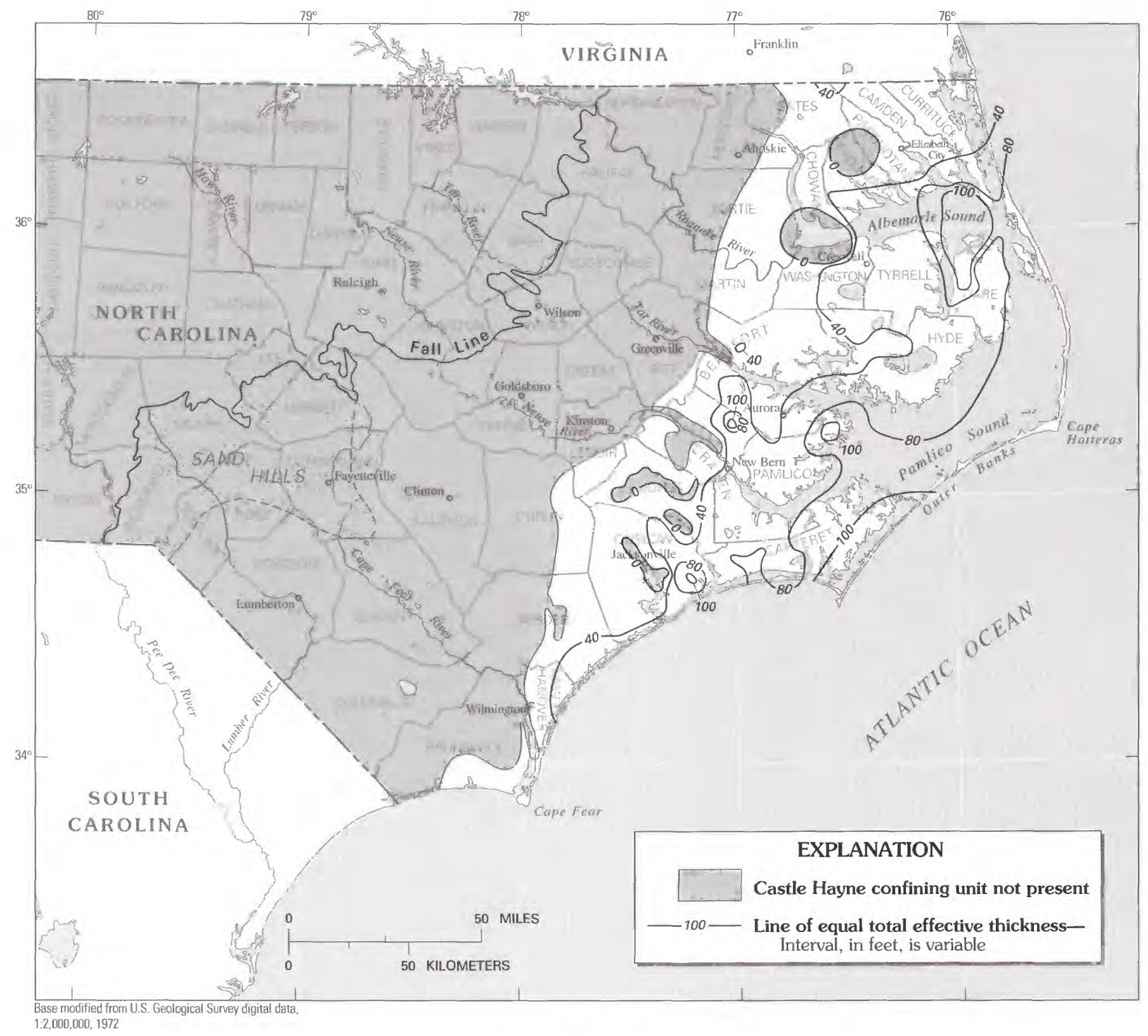

Figure 37.-Total effective thickness of the Castle Hayne confining unit (CU7). 


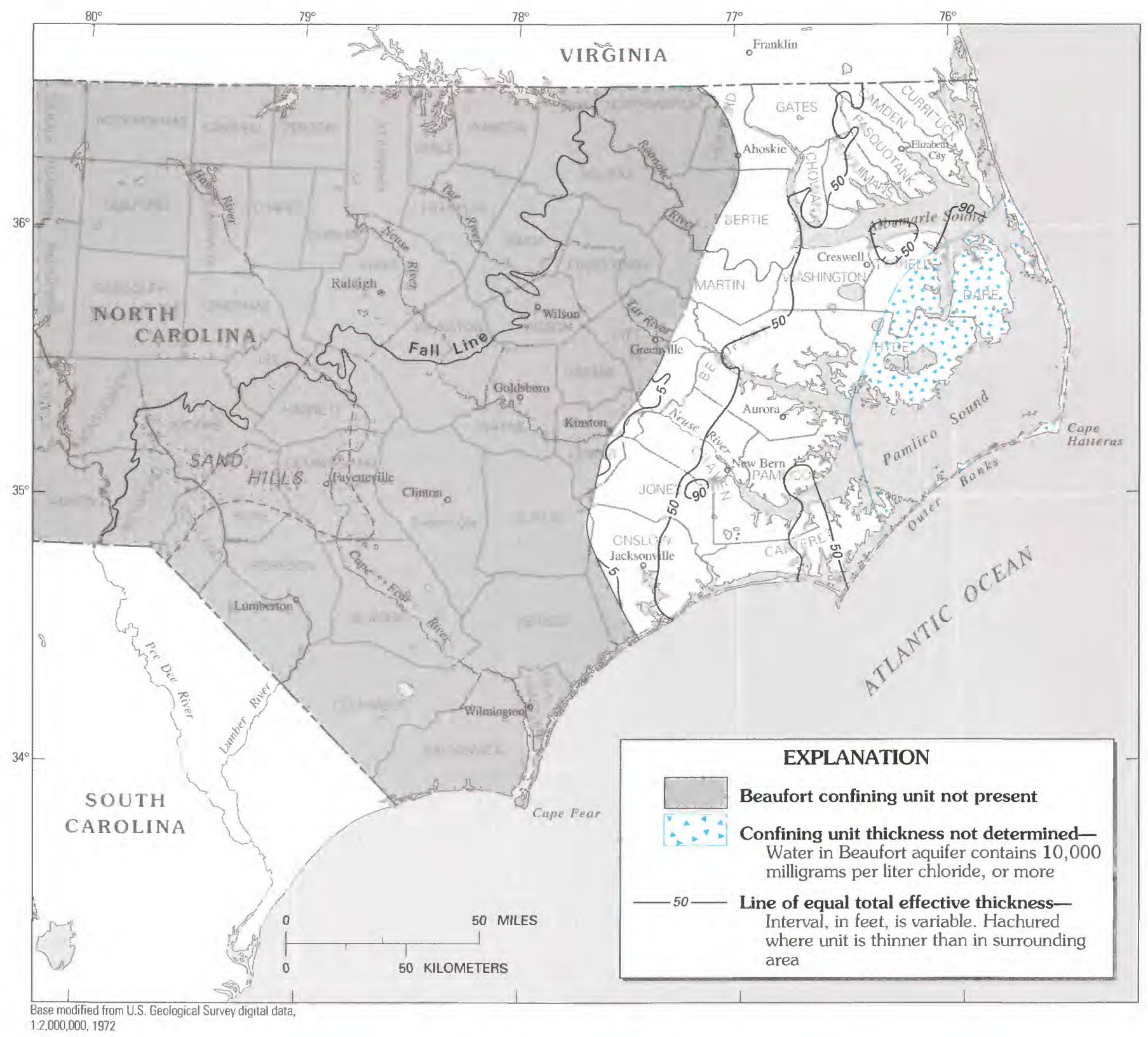

FIGURE 38.-Total effective thickness of the Beaufort confining unit (CU6). 


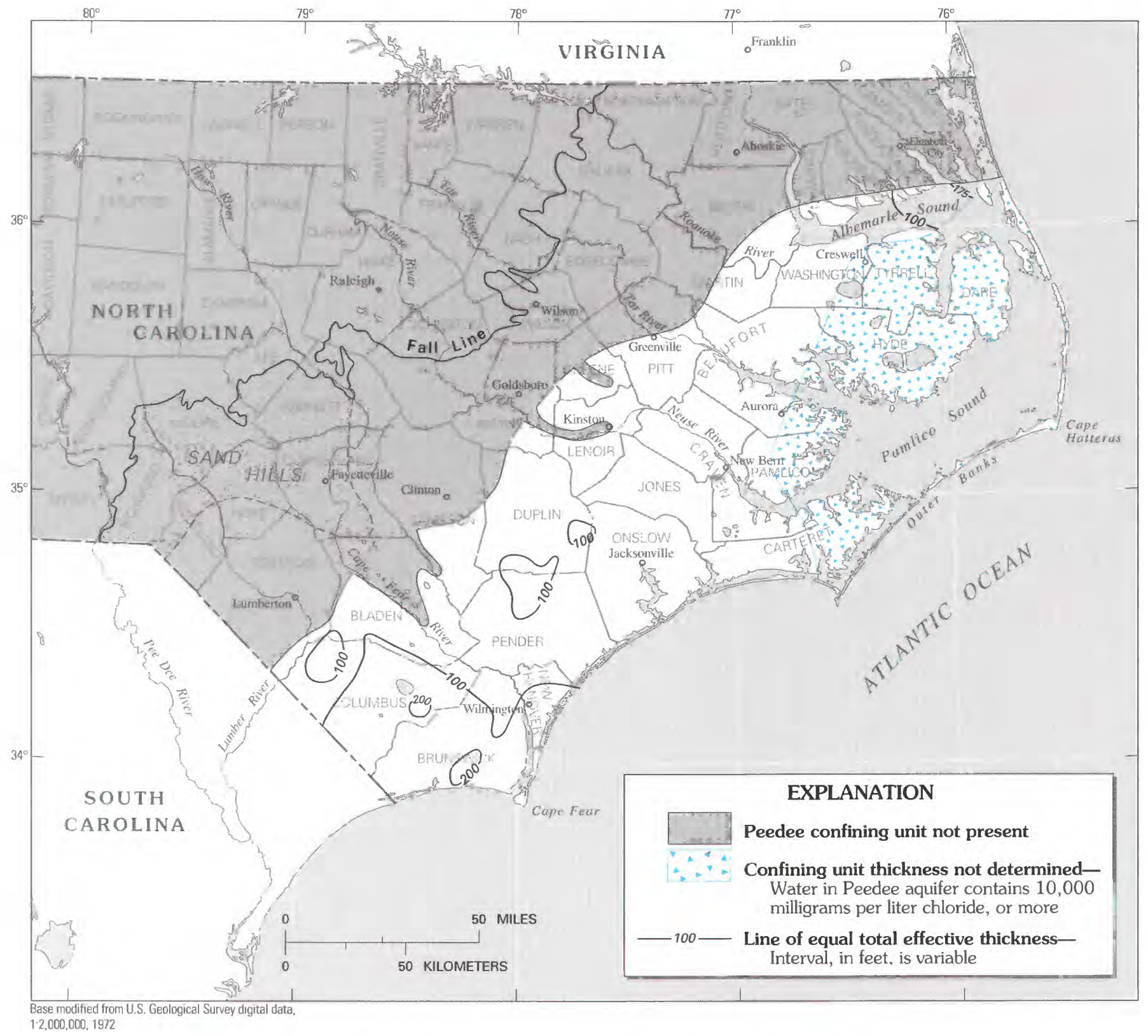

Figure 39.-Total effective thickness of the Peedee confining unit (CU5). 


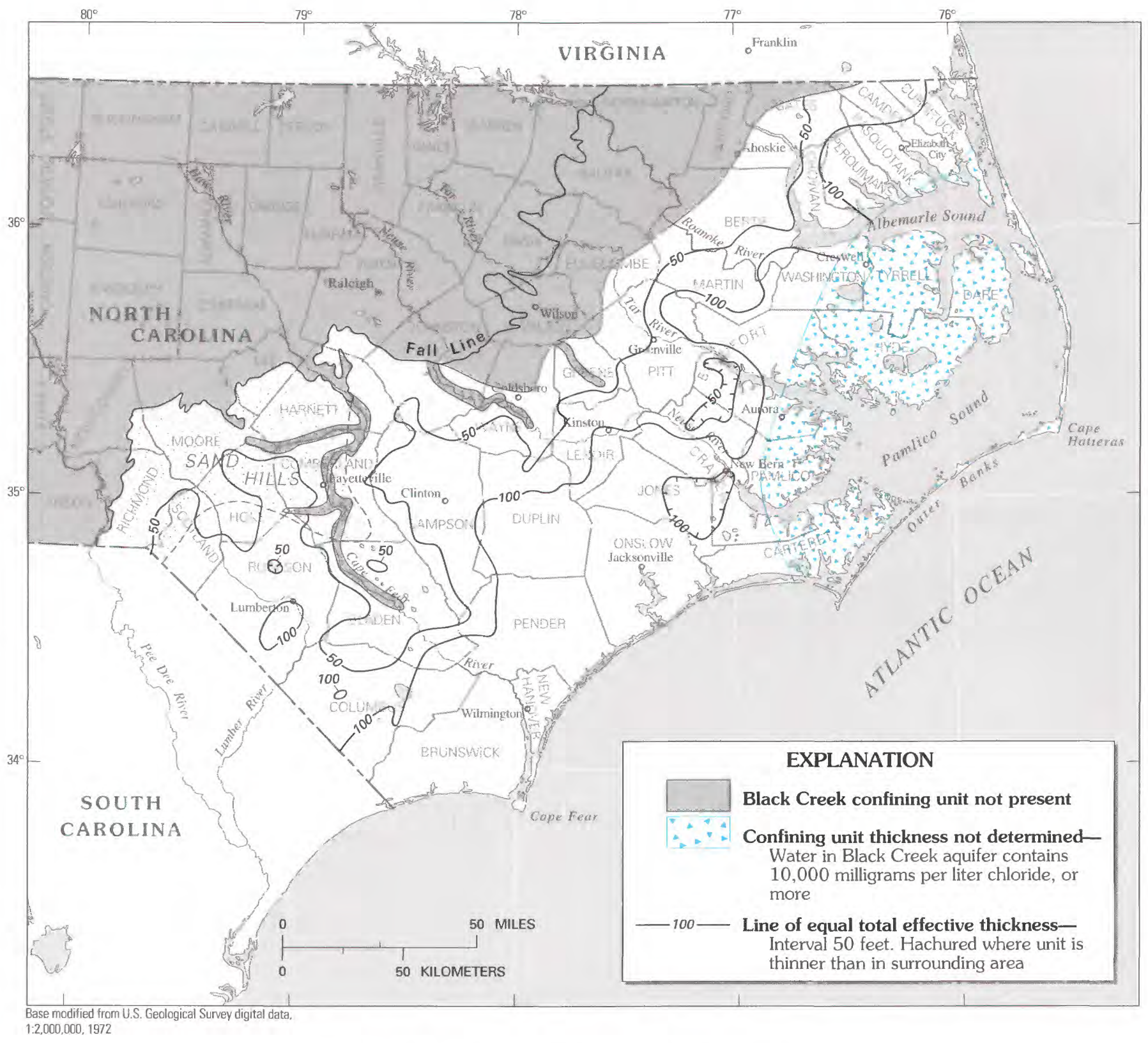

Figure 40,-Total effective thickness of the Black Creek confining unit (CU4). 


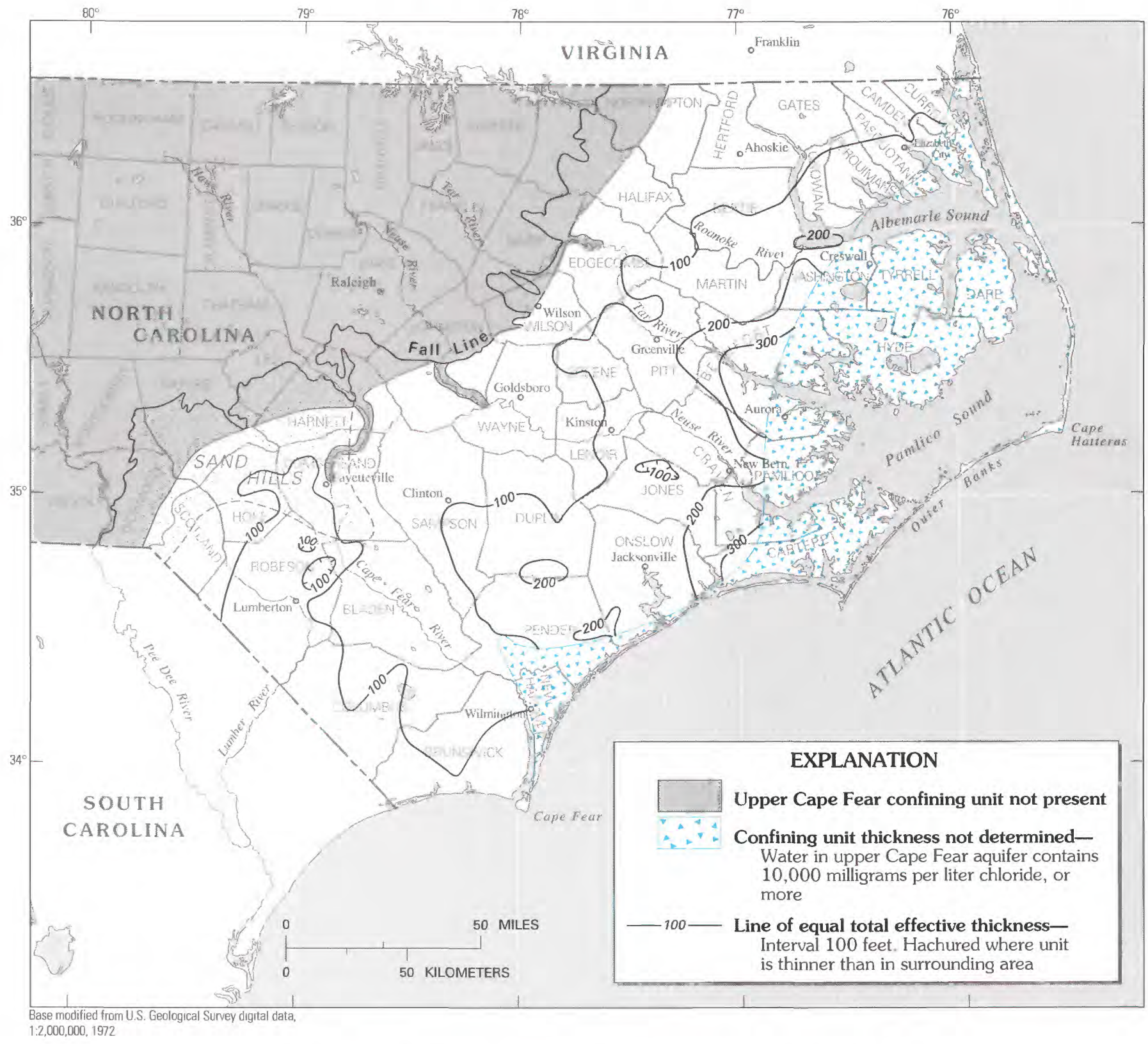

Figure 41.-Total effective thickness of the upper Cape Fear confining unit (CU3). 


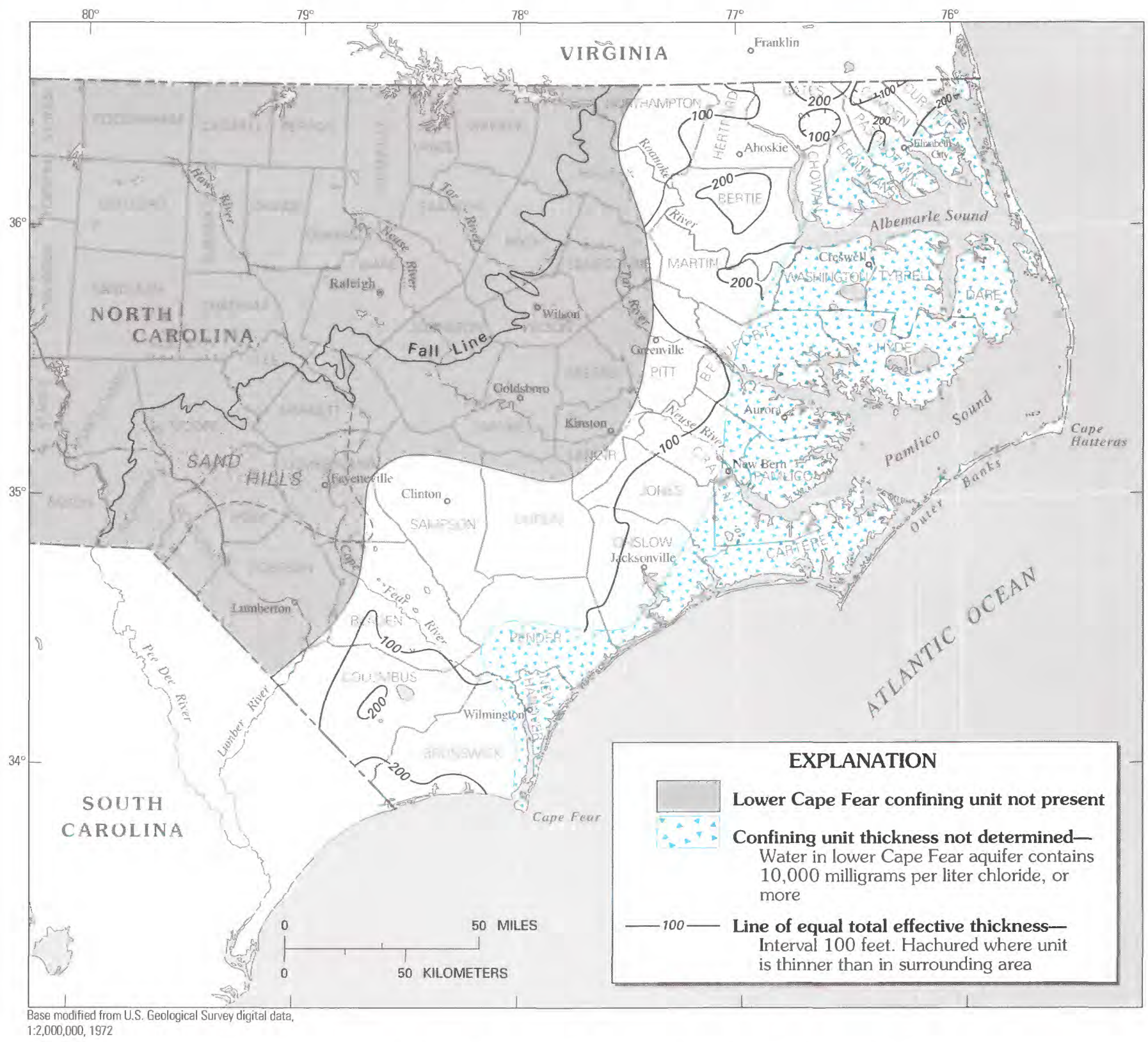

FIGURE 42.-Total effective thickness of the lower Cape Fear confining unit (CU2). 


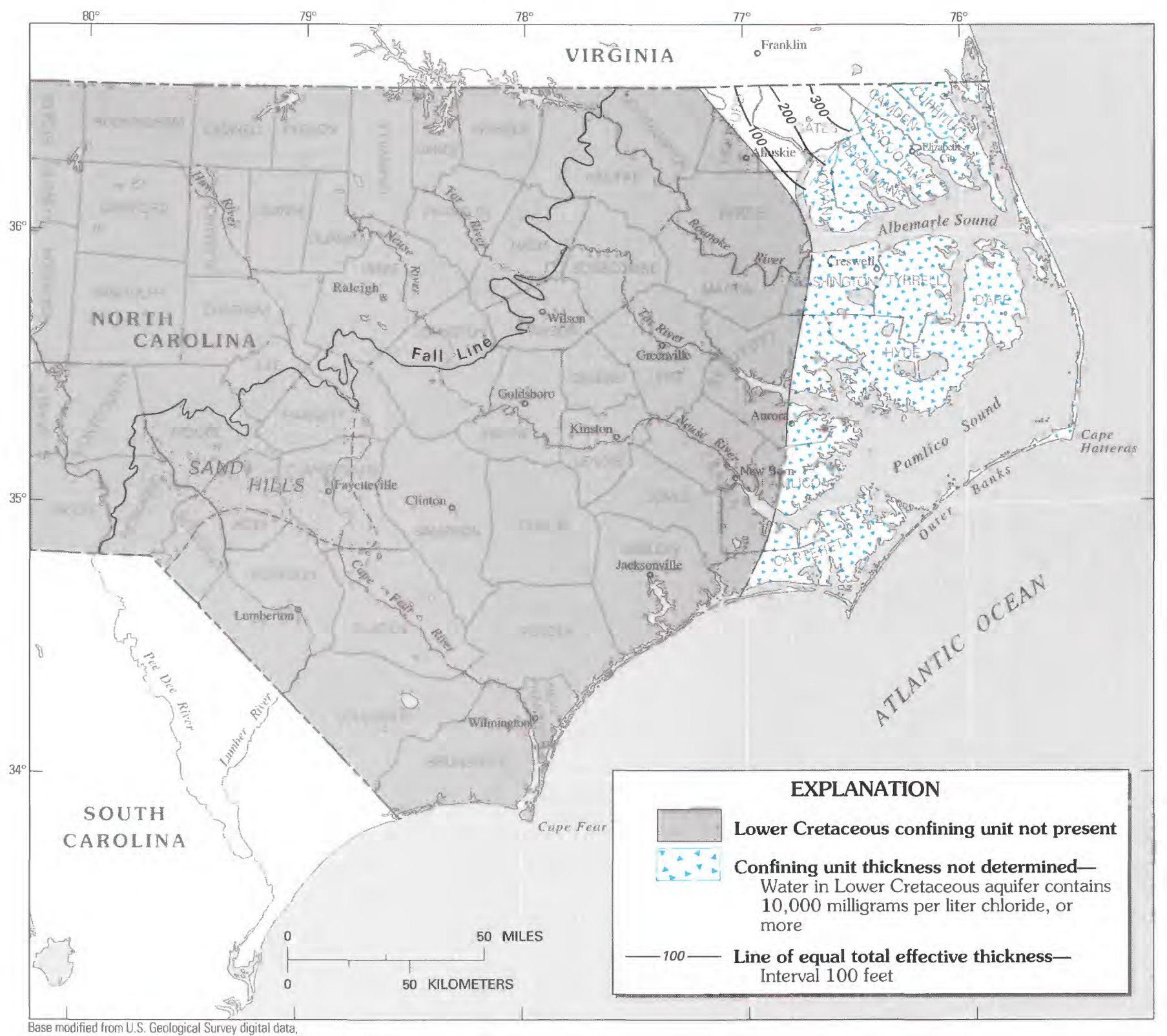
Base modified from U.S. Geological Survey digital data,
$12,000,000,1972$

FIGURE 43.-Total effective thickness of the Lower Cretaceous confining unit (CU1). 

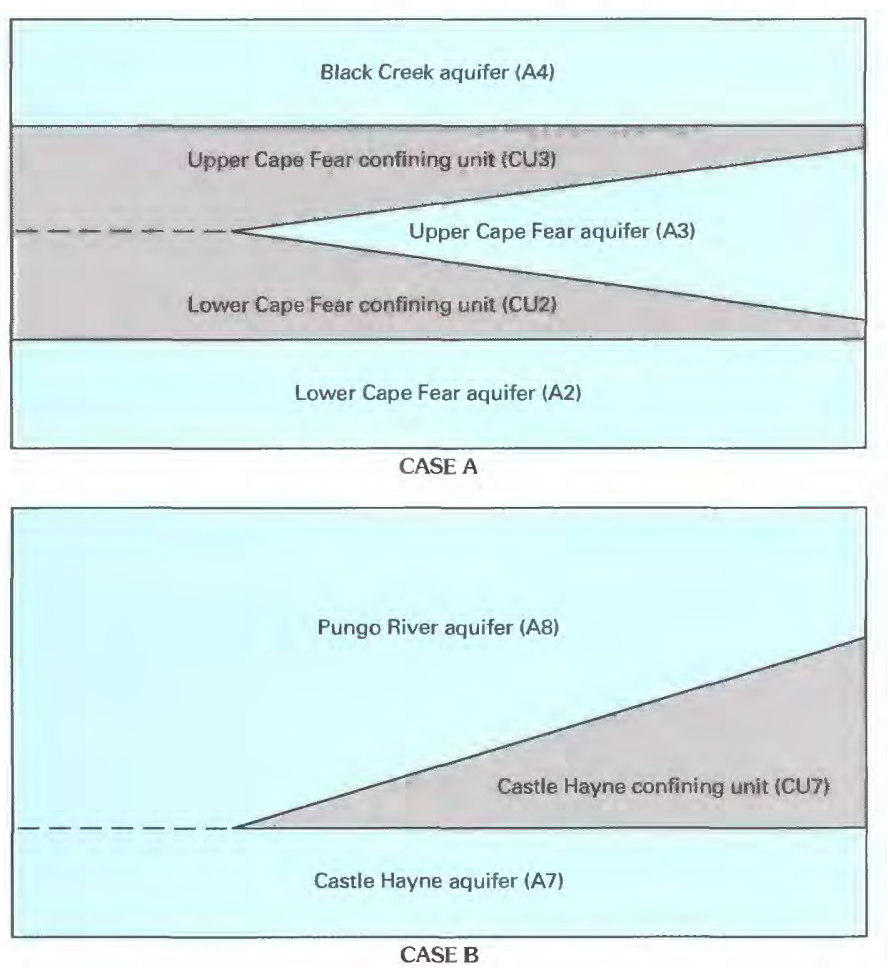

FIGURE 44.-Schematic diagram illustrating aquifer or confining-unit pinchout as applied to model structure.

Initial values for $K_{v}$, representing the vertical hydraulic conductivity of confining-unit material, were based on appraisals of confining-unit effectiveness derived from geophysical logs, chemical analyses, differences in head between aquifers above and below the confining unit, and values of vertical hydraulic conductivity for various materials given by Morris and Johnson (1967, table 6). These initial values ranged from $1 \times 10^{-3} \mathrm{ft} / \mathrm{d}$ to $4 \times 10^{-6} \mathrm{ft} / \mathrm{d}$.

At many locations, two or more confining units need to be considered for modeling purposes as occurring between two nonsequential aquifers (case $\mathrm{A}$ in fig. 44). For example, the lower Cape Fear aquifer (A2) may be present, and directly above it the lower Cape Fear confining unit (CU2) and the Black Creek aquifer (A4) may be present. The upper Cape Fear aquifer (A3) and upper Cape Fear confining unit (CU3) are missing in this example. In this situation the lower Cape Fear confining unit (CU2) is considered as being composed of two confining units: half of the effective thickness belongs to the lower Cape Fear confining unit (CU2) and the other half belongs to the upper Cape Fear confining unit (CU3), even though the upper Cape Fear confining unit (CU3) is not present. In general, the confining unit is divided into
$N+1$ equal parts, where $N$ is the number of missing aquifers. Although the transmissivity of the missing aquifers is zero at these locations and no horizontal flow can occur, the modified version of the Trescott flow model used in this study (described in detail by Leahy (1982)) allows for vertical movement of water at these locations.

The opposite situation is where a confining unit is missing and two aquifers are in direct contact (case B in fig. 44). This condition was simulated by arbitrarily assigning small confining-unit thicknesses ranging from 0.01 to $0.001 \mathrm{ft}$. This occurs mostly in stream valleys where the surficial aquifer (A10) is in direct contact with an underlying aquifer and results in high leakance values. A notable exception is in the western Pamlico Sound area, where the Pungo River aquifer (A8) is in direct contact with the underlying Castle Hayne aquifer (A7).

The leakance $(T K)$ values for the confining units from the calibrated model are shown in figures 45 through 53. The rationale for varying leakance values during calibration is discussed in the "Model Calibration" section later in this report.

\section{Ground-Water Withdrawals and Time Discretization}

In order to simulate the behavior of the North Carolina Coastal Plain aquifer system through time, it was necessary to develop pumpage histories for major ground-water users; that is, users who withdraw 100,000 gallons per day (gal/d) or more. This information was gathered primarily from interviews with personnel of public-supply systems and self-supplied industries during 1982-83 and was supplemented by reports and data of the U.S. Geological Survey (Robison (1977) and Robison and Mann (1977)), the North Carolina Department of Environment, Health, and Natural Resources, formerly called the North Carolina Department of Natural Resources and Community Development (1983), and the North Carolina Department of Human Resources.

Withdrawals by more than 115 public supplies and industries in the survey exceeded $195 \mathrm{Mgal} / \mathrm{d}$ during 1980, doubling about every decade from 1940 to 1970 (fig. 54). The largest single user is a phosphate-mining and chemical-production operation in Beaufort County, which began withdrawals in 1965 at a rate of $31 \mathrm{Mgal} / \mathrm{d}$. By 1980, withdrawals for this operation had leveled off at a rate of about $64 \mathrm{Mgal} / \mathrm{d}$. Sharp declines in pumpage in $1944,1945,1961$, and 1964 are entirely due to decreases in pumpage at two rock quarries in Onslow and Craven Counties; sharp increases in 1945 and 1958 are due to pumpage increases at these same two quarries.

\footnotetext{
Text continues on p. M64.
} 


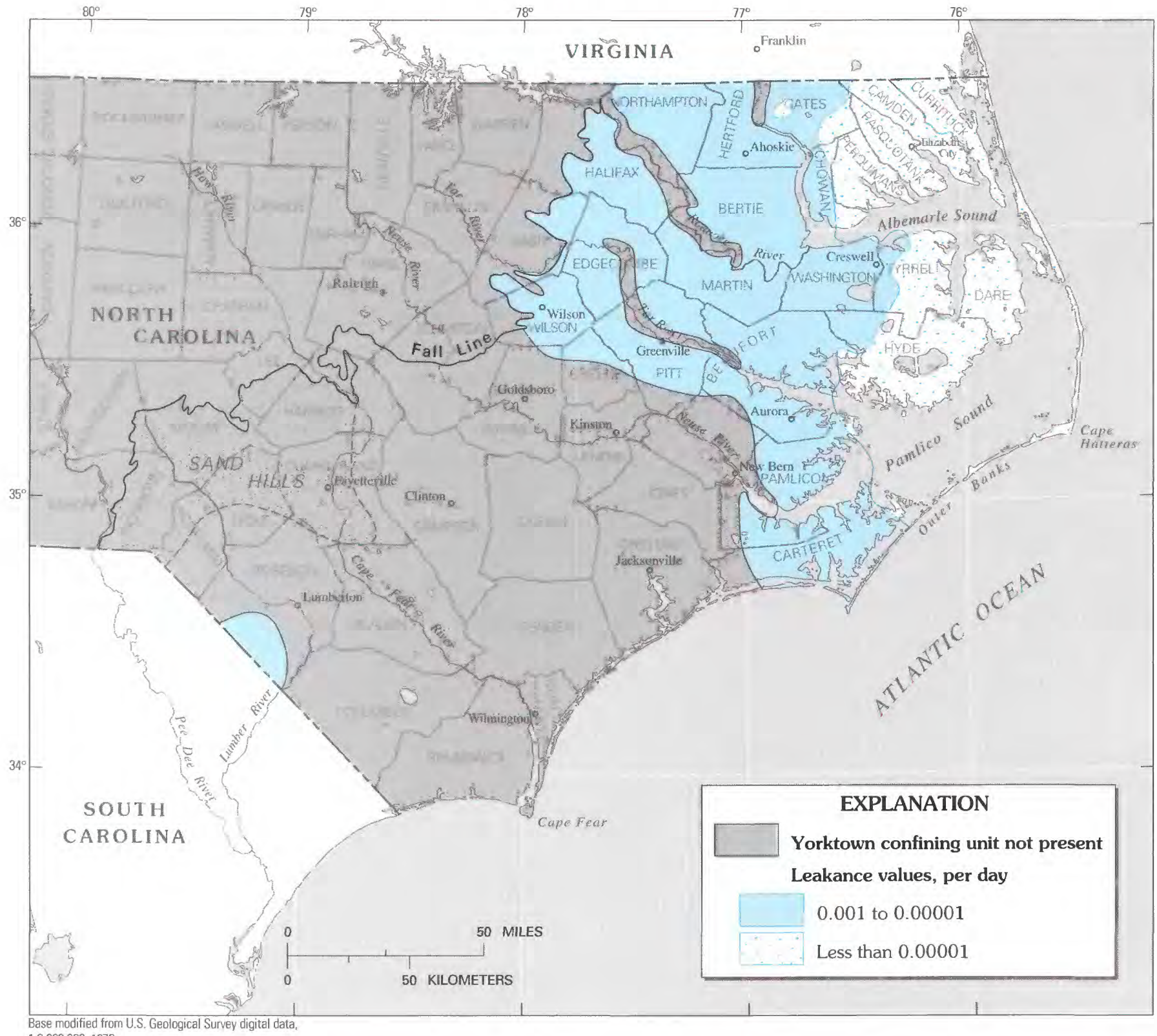

Figure 45.-Model-derived leakance (TK) of the Yorktown confining unit (CU9). 


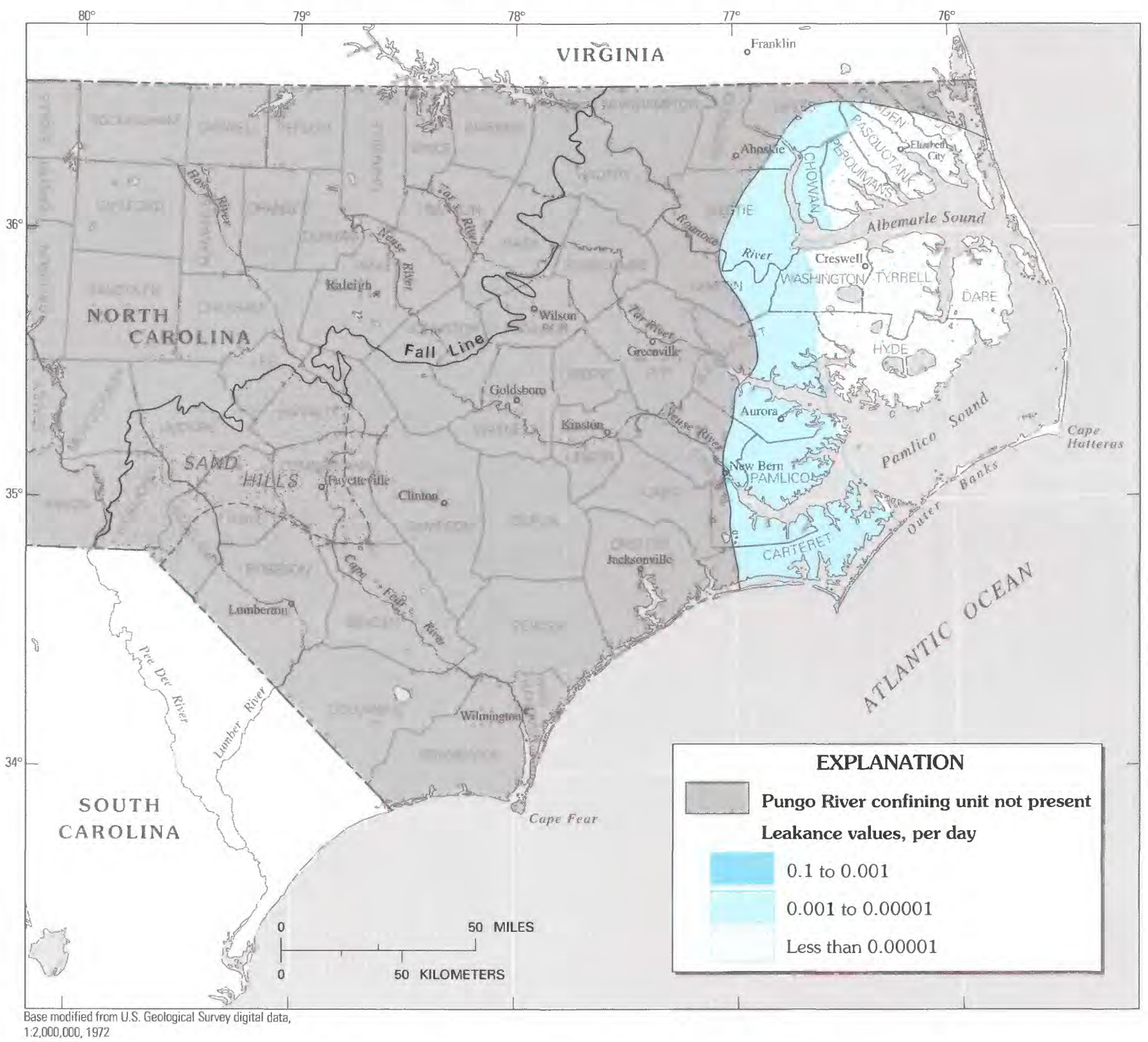

FIgURE 46.-Model-derived leakance ( $T K$ ) of the Pungo River confining unit (CU8). 


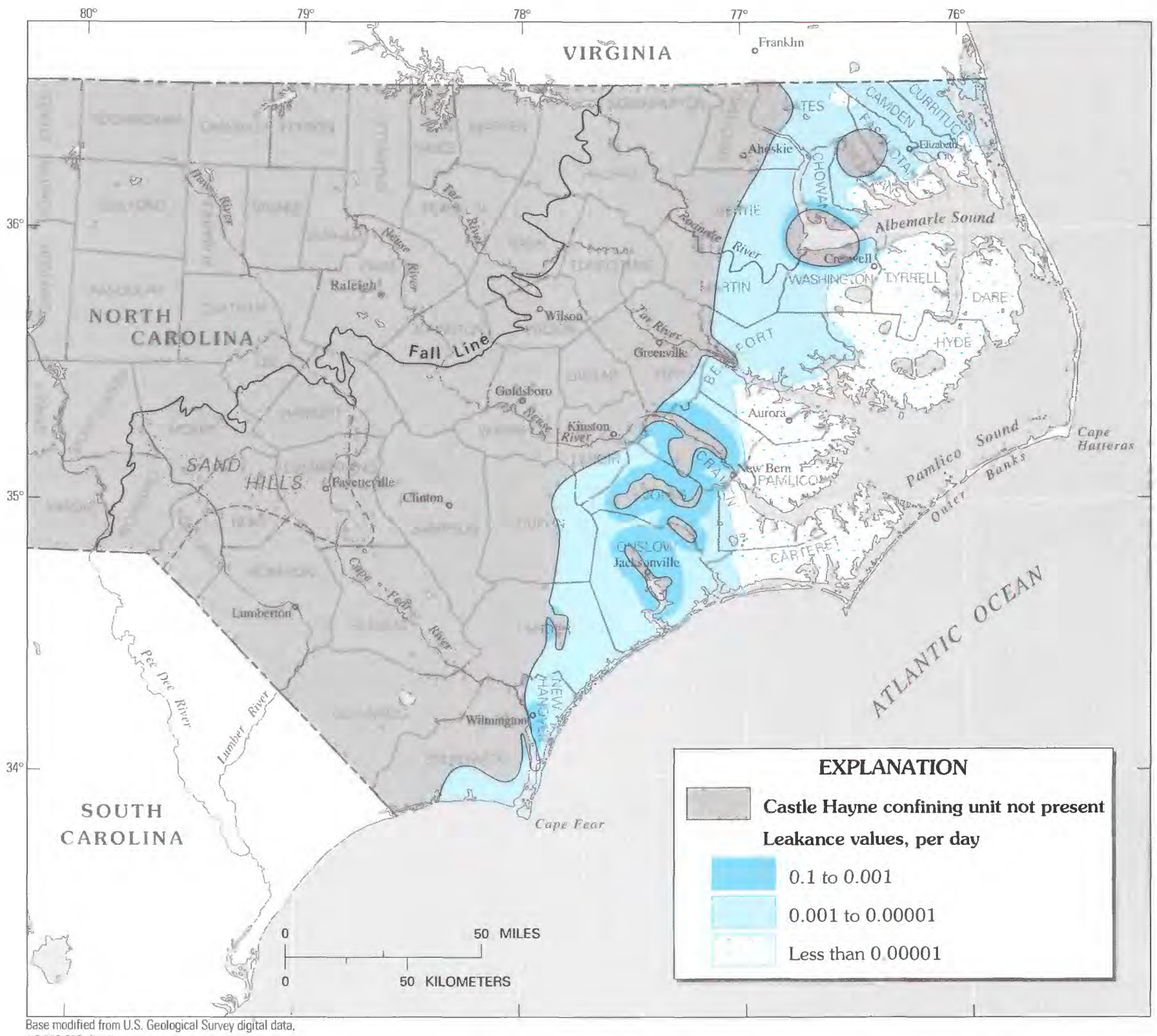

FIGURE 47.-Model-derived leakance (TK) of the Castle Hayne confining unit (CU7). 


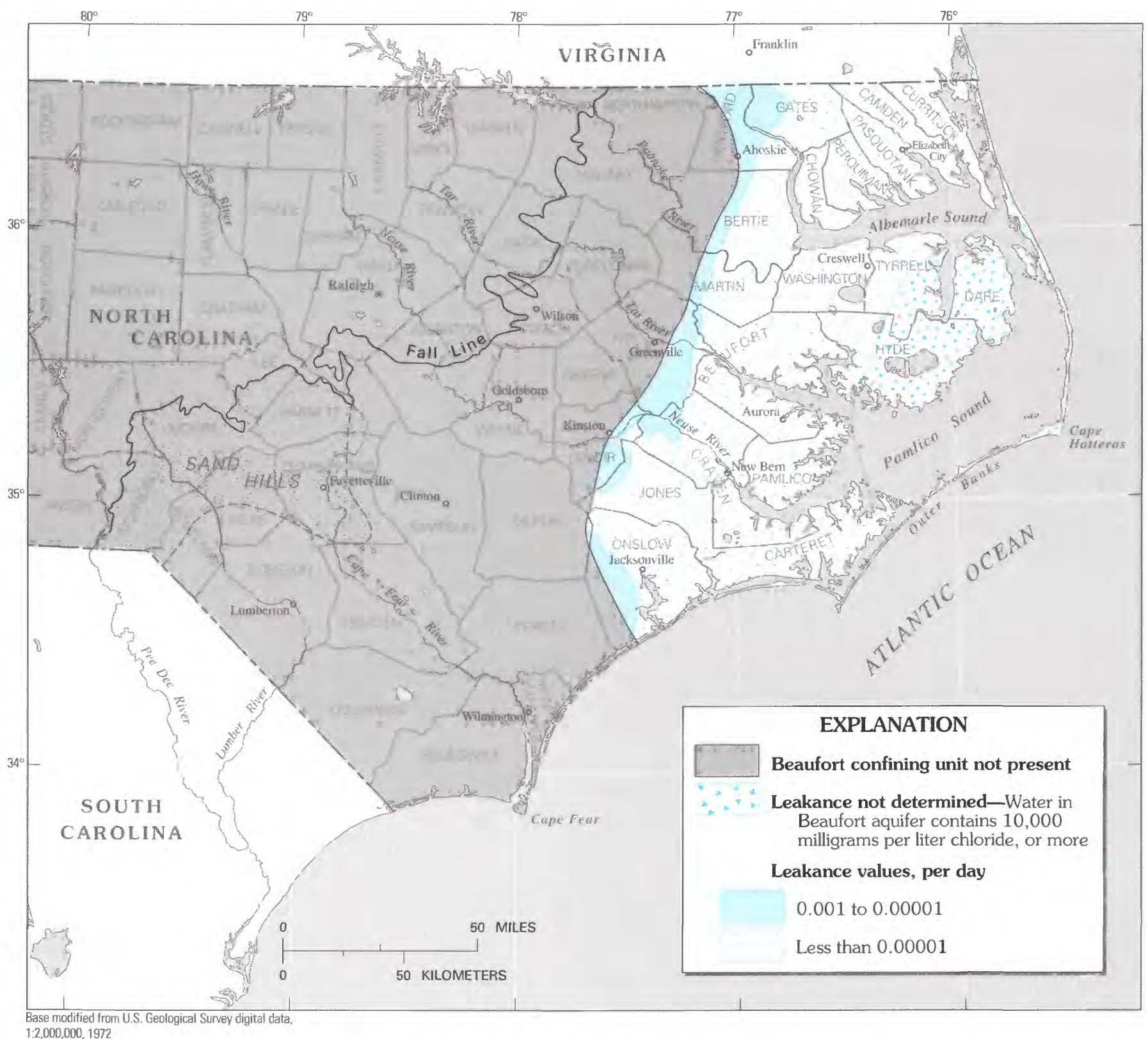

Figure 48.-Model-derived leakance (TK) of the Beaufort confining unit (CU6). 


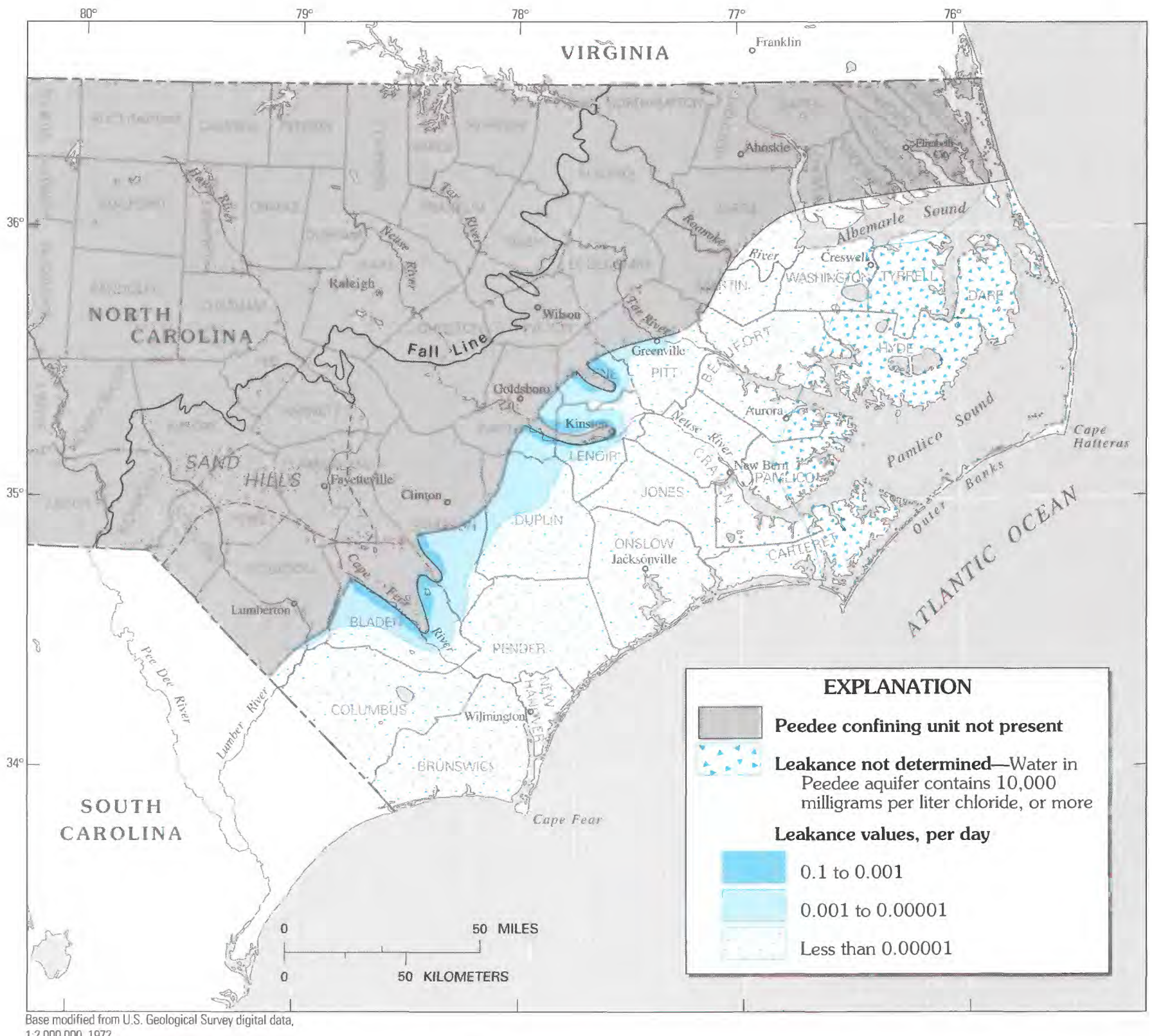

Figure 49.-Model-derived leakance (TK) of the Peedee confining unit (CU5). 


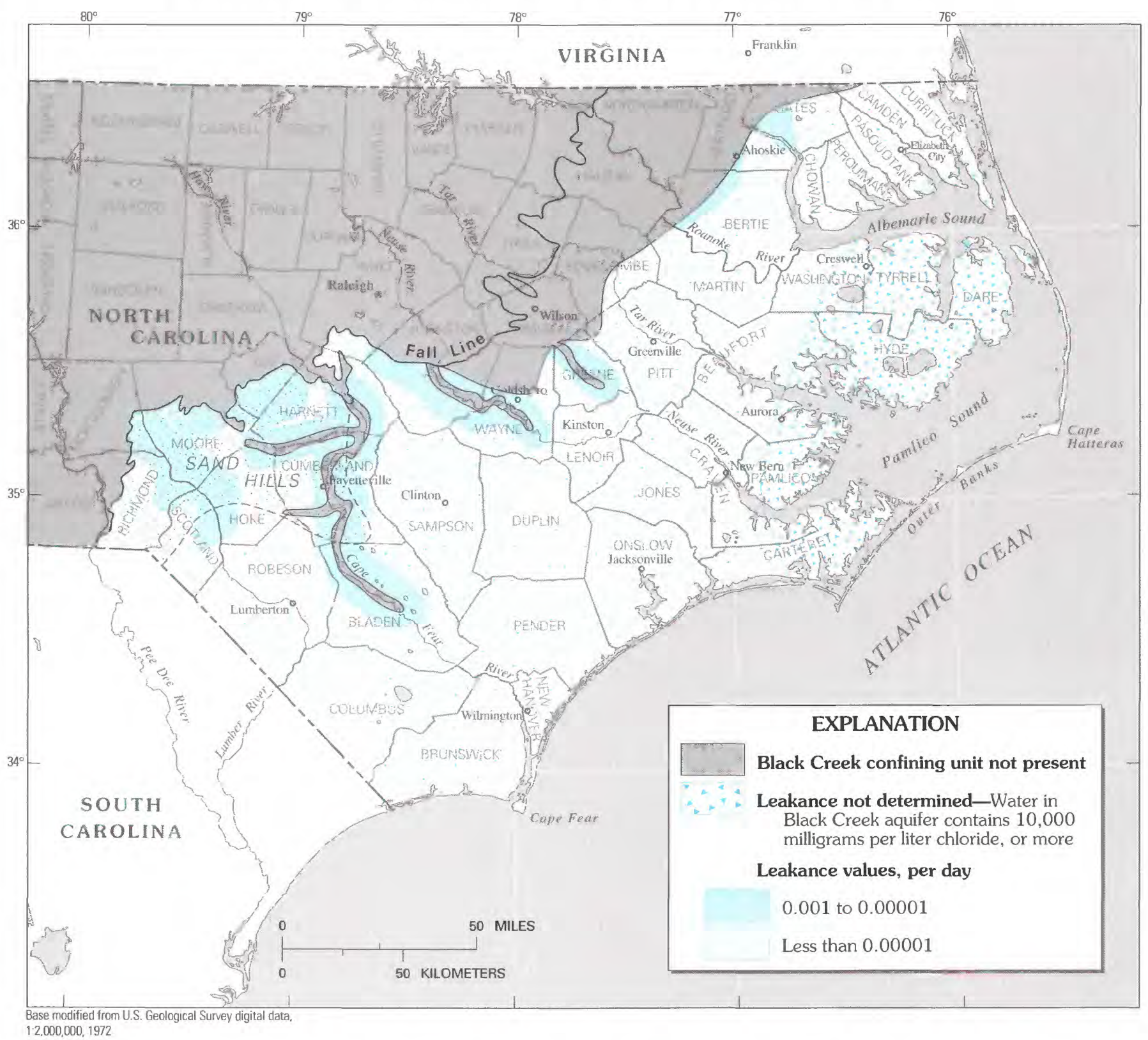

Figure 50,-Model-derived leakance (TK) of the Black Creek confining unit (CU4). 


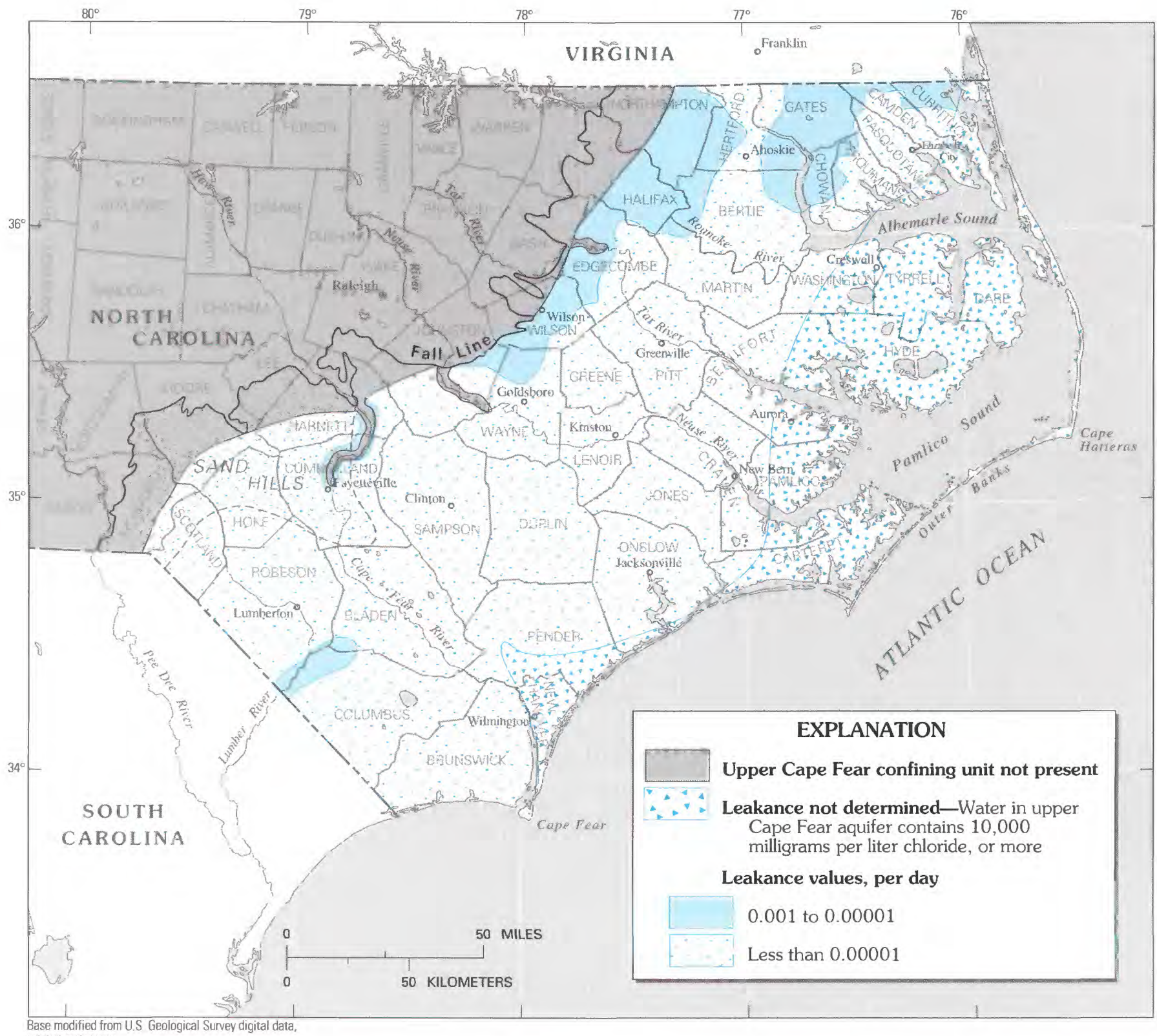

FIGURE 51-Model-derived leakance (TK) of the upper Cape Fear confining unit (CU3). 


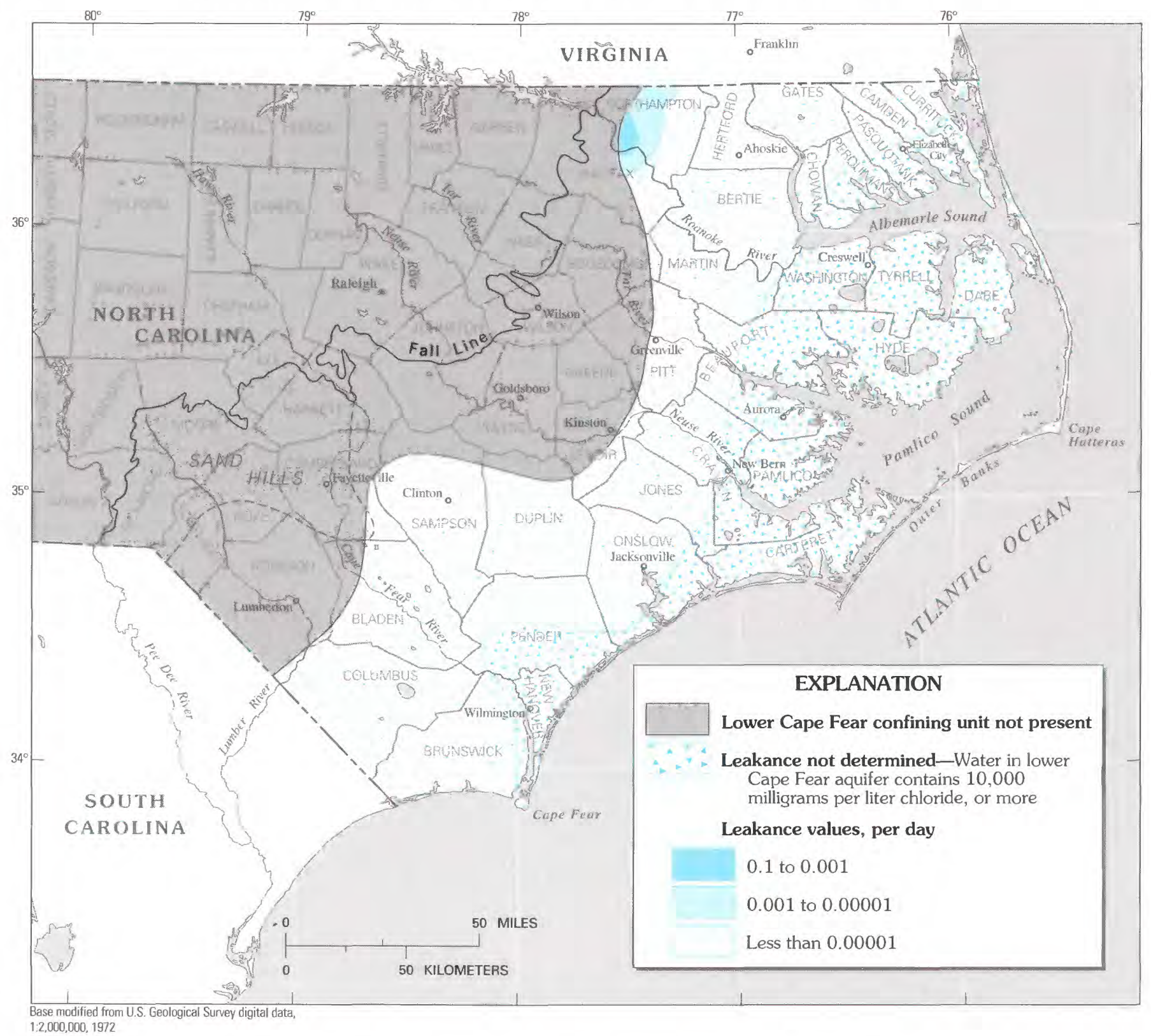

Figure 52-Model-derived leakance (TK) of the lower Cape Fear confining unit (CU2). 


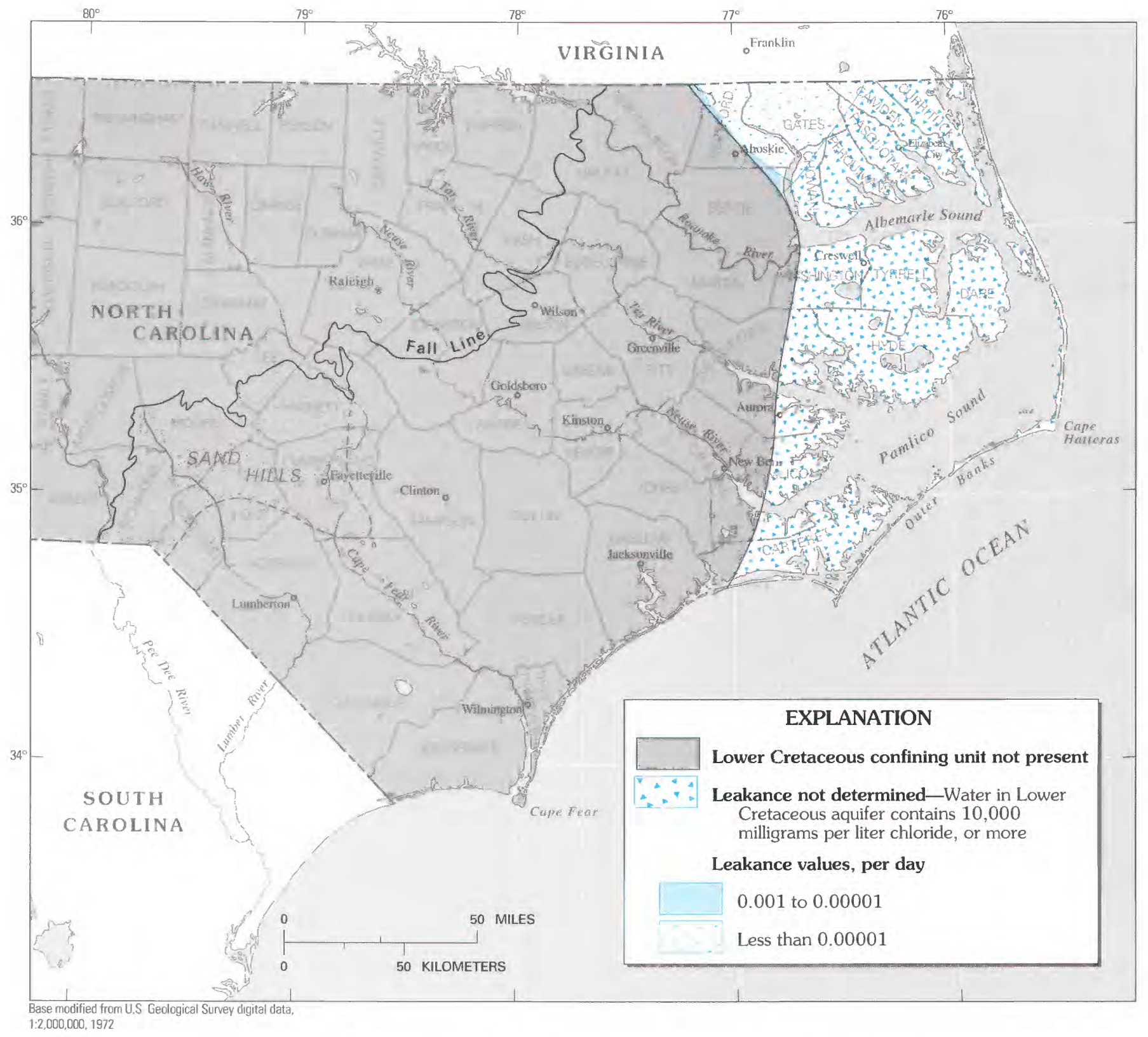

FIGURE 53.-Model-derived leakance (TK) of the Lower Cretaceous confining unit (CU1). 


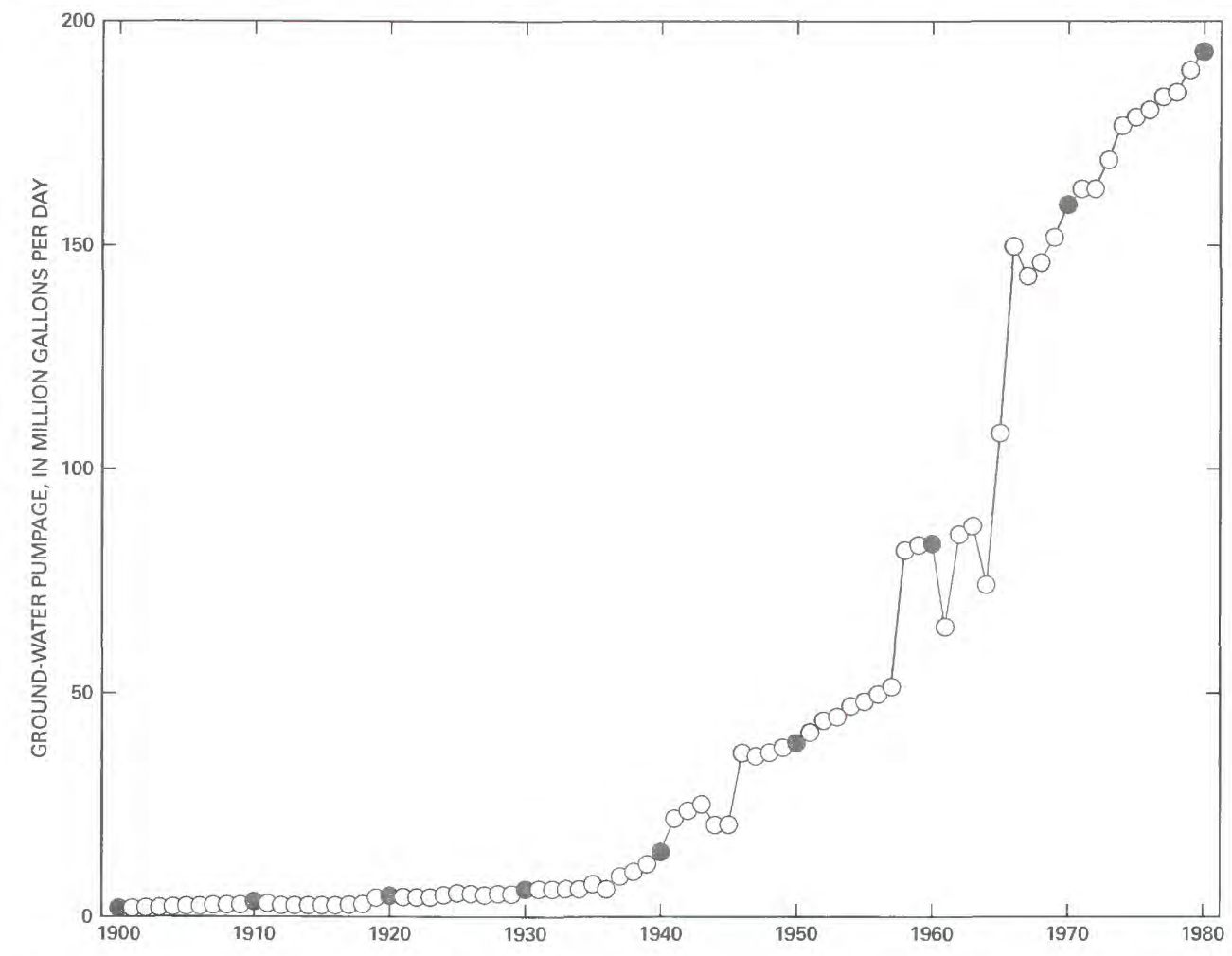

Figure 54.-Ground-water pumpage in the North Carolina Coastal Plain, 1900-80, for users of more than 100,000 gallons per day.

To simulate the flow system over time, the period from January 1, 1900, to January 1, 1981, was divided into 10 time periods; within each period, pumpage is treated as a constant. The 10 time periods chosen are as follows:

$\begin{array}{ccc}\text { Time period } & \text { Inclusive dates } & \text { Length of time period (years) } \\ 1 & 1900-20 & 21 \\ 2 & 1921-39 & 20 \\ 3 & 1940-45 & 6 \\ 4 & 1946-52 & 7 \\ 5 & 1953-57 & 5 \\ 6 & 1958-64 & 7 \\ 7 & 1965-67 & 3 \\ 8 & 1968-72 & 5 \\ 9 & 1973-77 & 5 \\ 10 & 1978-80 & 3\end{array}$

The locations of withdrawals greater than $100,000 \mathrm{gal} / \mathrm{d}$ are shown for all aquifers above the Lower Cretaceous aquifer (A1) in figures 55 through 63 . (There are none in the Lower Cretaceous aquifer within North Carolina.) Table 2 shows the 1980 pumpages by aquifer.

The pumpage survey conducted as a part of this study is considered to be fairly complete for large public and industrial ground-water users, but no irrigation water-use data were included in the survey. Ground water used for irrigation represents a small but rapidly increasing component of total water use in the North
Carolina Coastal Plain, and only one published inventory presently exists (North Carolina Department of Natural Resources and Community Development and U.S. Water Resources Council, 1983). For calibration, wells were selected that were unaffected by irrigation pumping. In addition, much of the ground water used for irrigation purposes is withdrawn from the surficial aquifer, and such withdrawals have little effect on the deeper confined aquifer system. Therefore, it is believed that the lack of irrigation pumpage data does not affect the values for transmissivity and confining-unit leakance arrived at through the calibration process.

Pumpage records prior to 1975 are incomplete and were estimated partly on the basis of population. Prior to the 1950 's, many ice plants in and around the major cities of the North Carolina Coastal Plain used large amounts of ground water (1 Mgal/d or more); however, these plants have been closed since the 1950's. The effects of these and other unmeasured withdrawals on 1980 water levels are judged to be small, largely because higher recharge rates induced by these withdrawals have replaced much of the water withdrawn decades earlier.

Text continues on p. M74. 


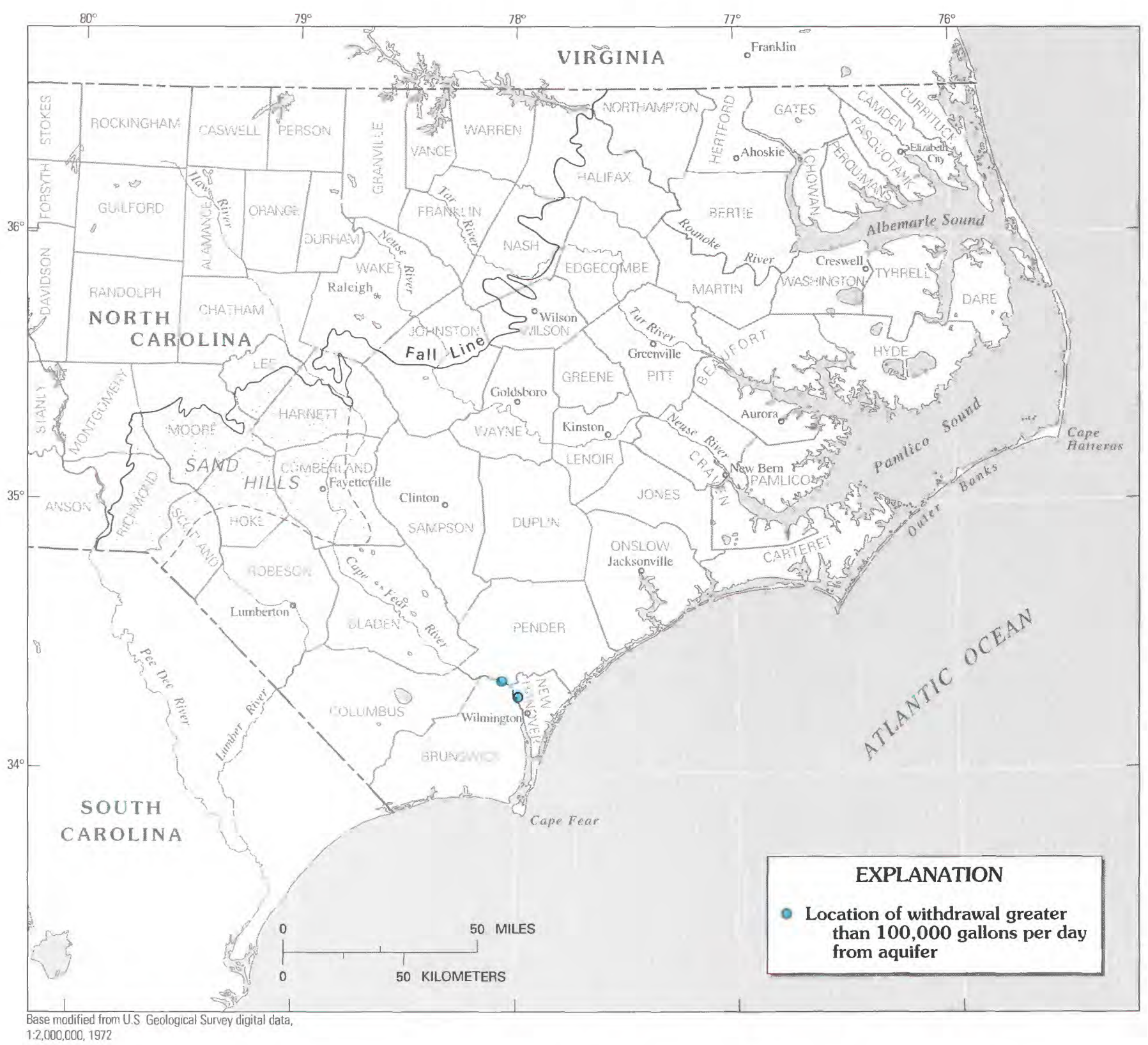

FIGURE 55.-Locations of withdrawals greater than 100,000 gallons per day for the surficial aquifer (A10) for 1980 . 


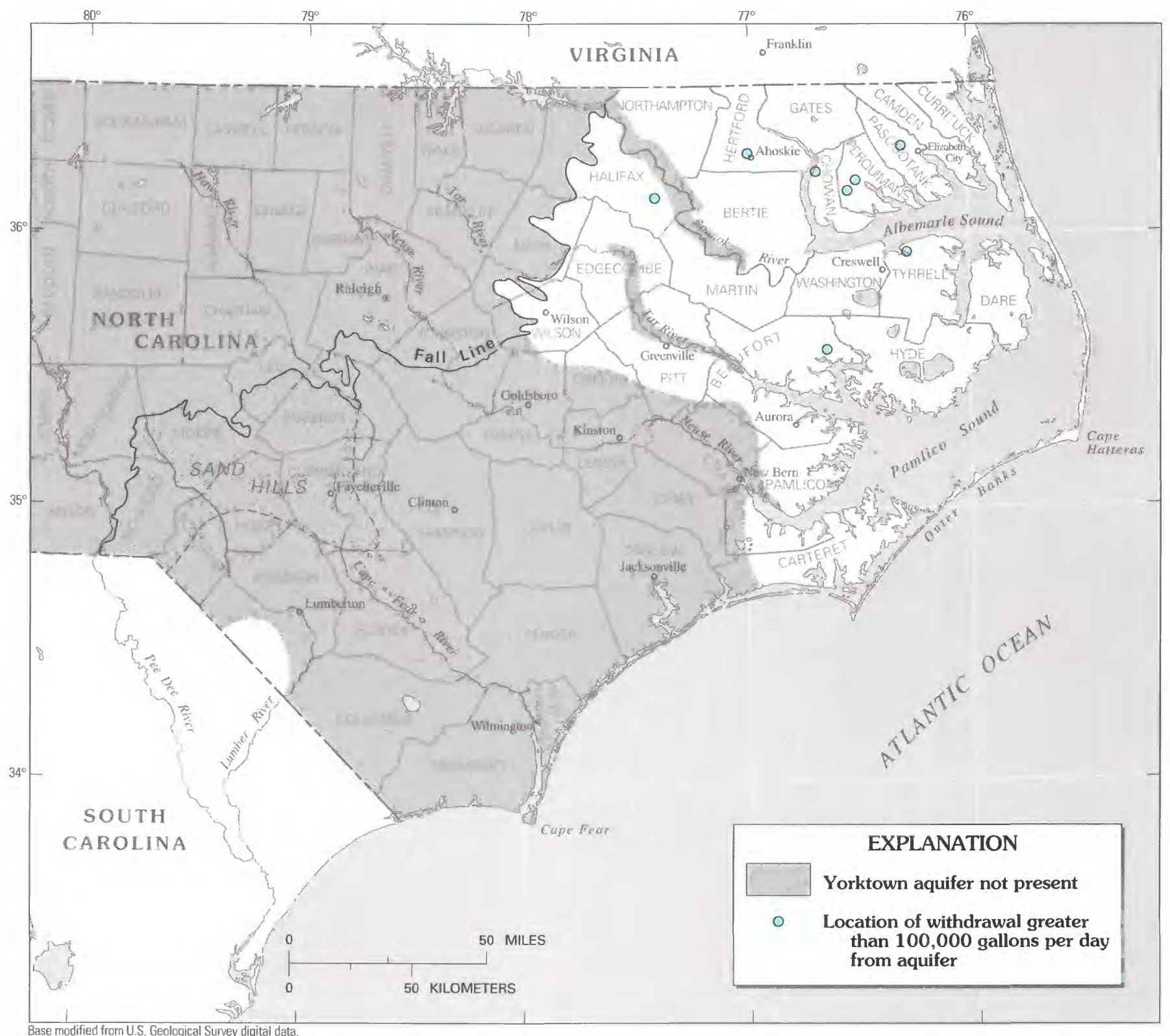

Base modified from U.S. Geological Survey digital data,

FIGURE 56.-Locations of withdrawals greater than 100,000 gallons per day for the Yorktown aquifer (A9) for 1980. 


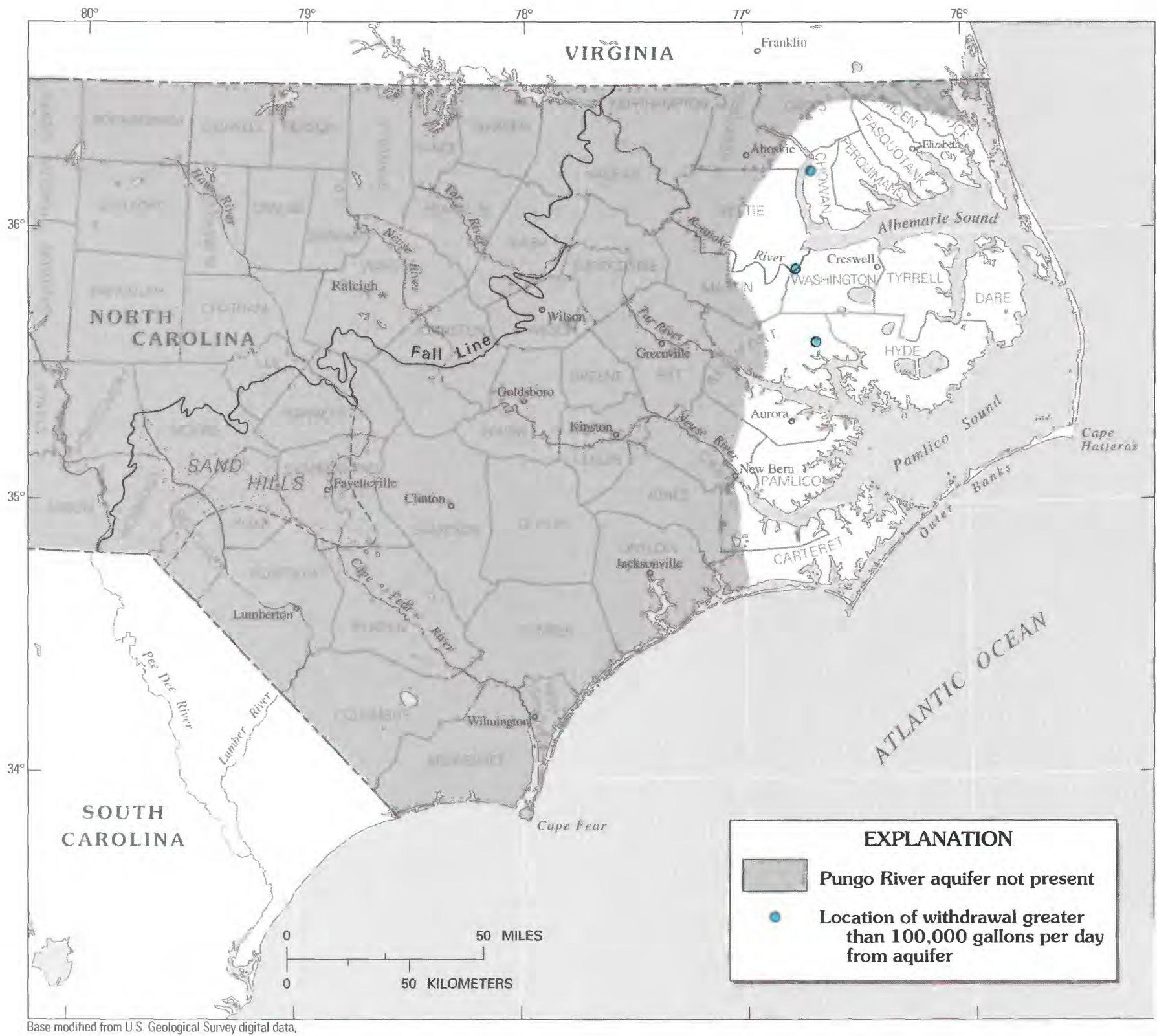

FIGURE 57.-Locations of withdrawals greater than 100,000 gallons per day for the Pungo River aquifer (A8) for 1980. 


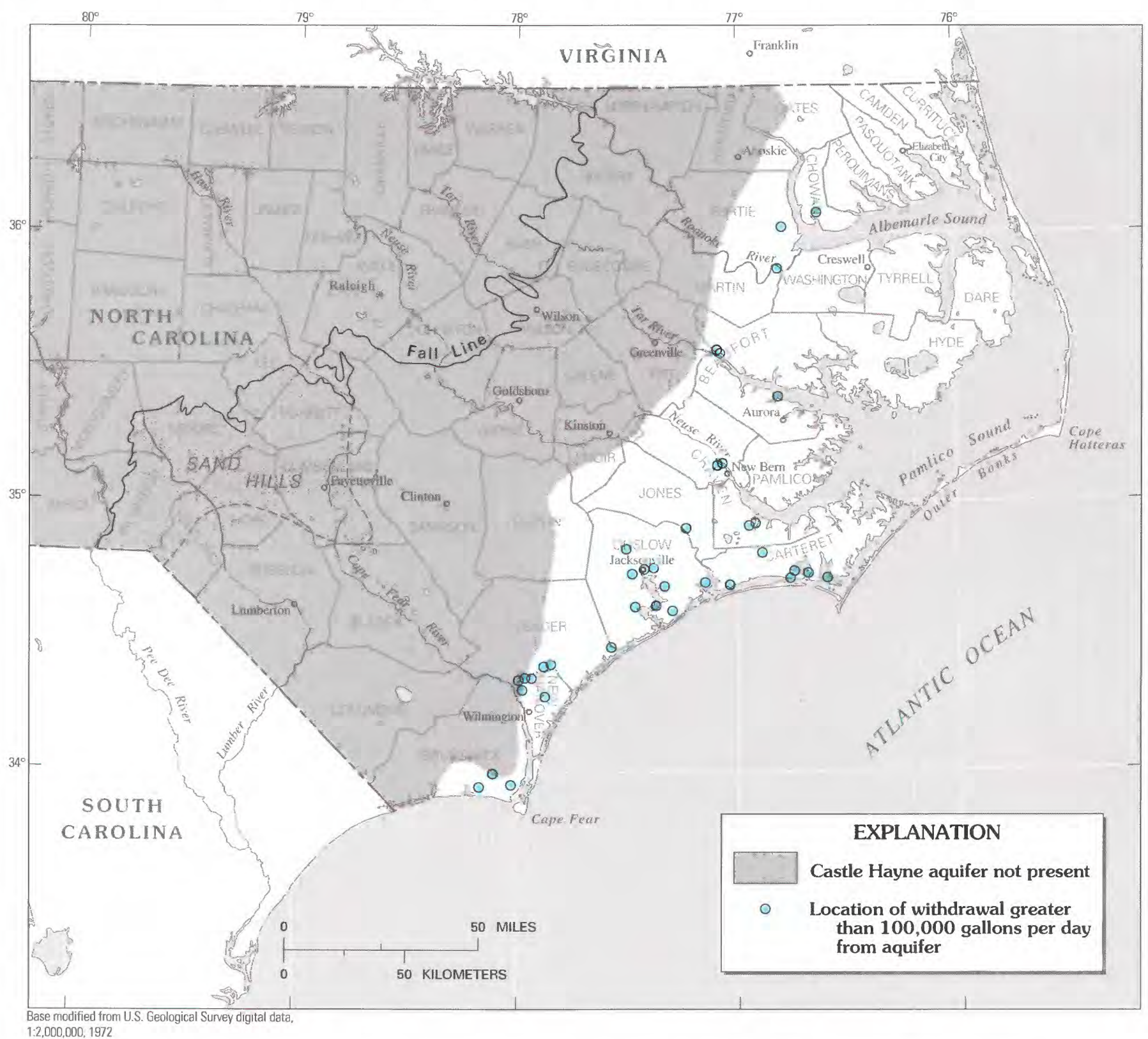

FIGURE 58.-Locations of withdrawals greater than 100,000 gallons per day for the Castle Hayne aquifer (A7) for 1980. 


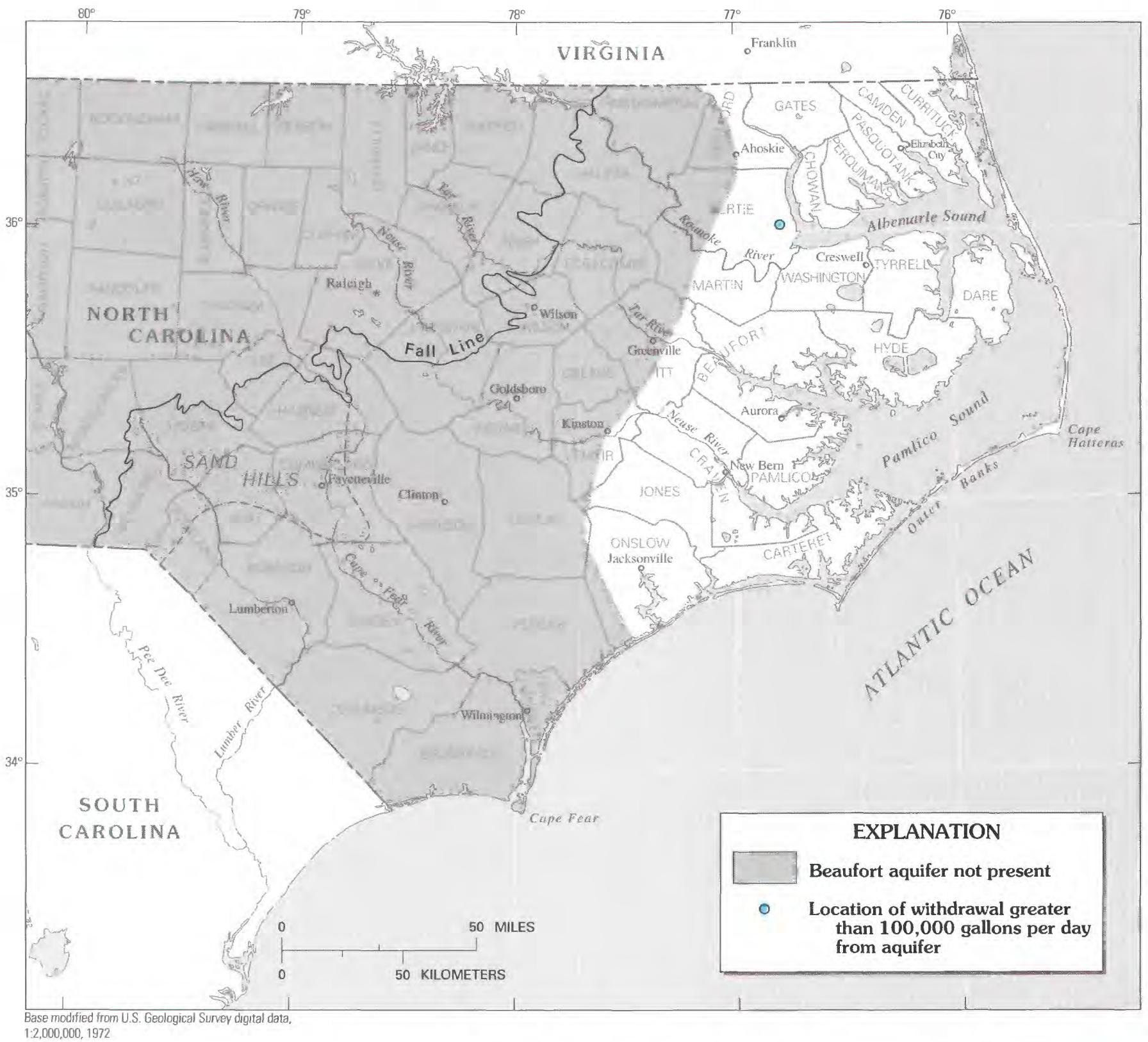

FIGURE 59.-Locations of withdrawals greater than 100,000 gallons per day for the Beaufort aquifer (A6) for 1980. 


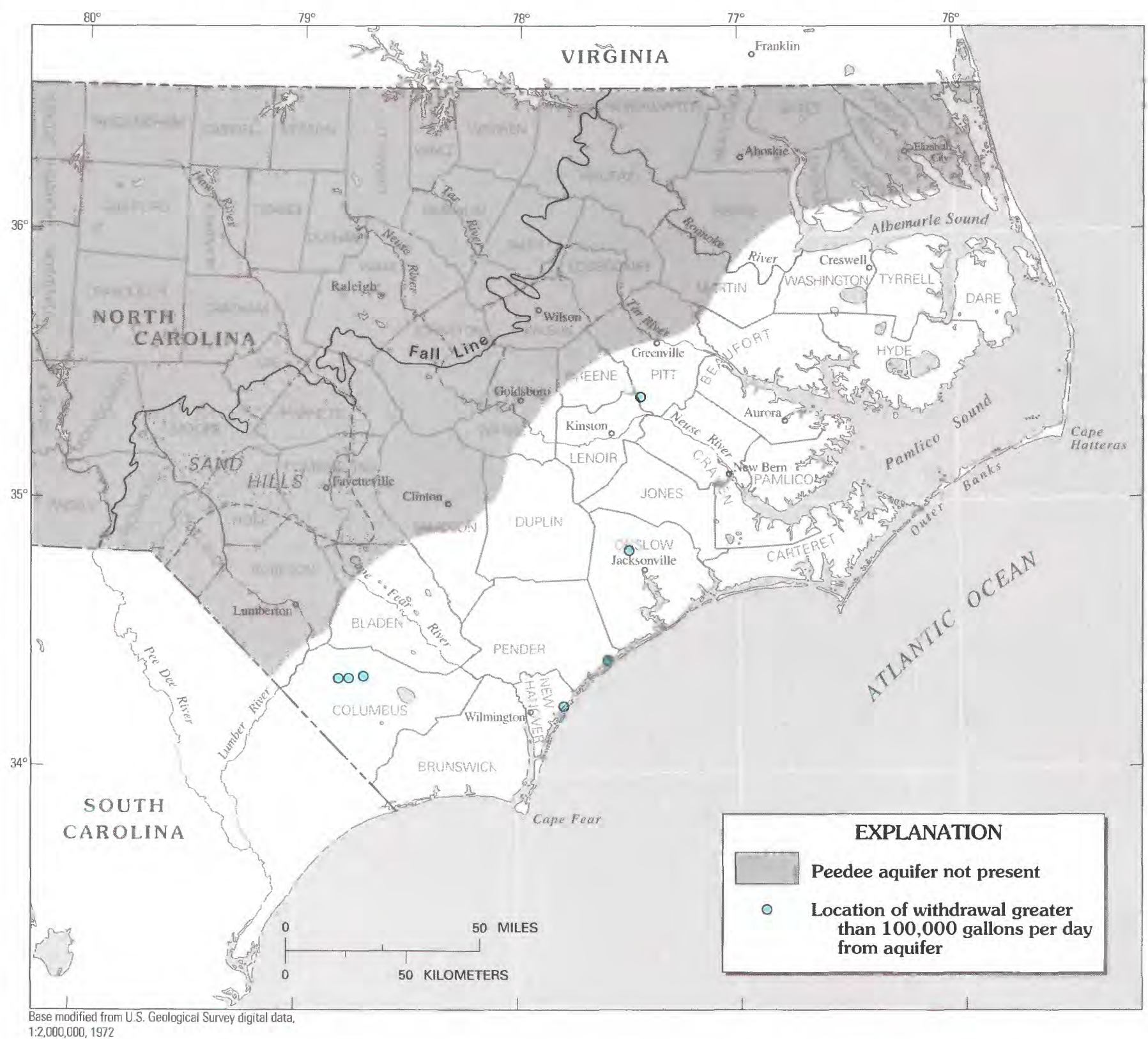

Figure 60.-Locations of withdrawals greater than 100,000 gallons per day for the Peedee aquifer (A5) for 1980. 


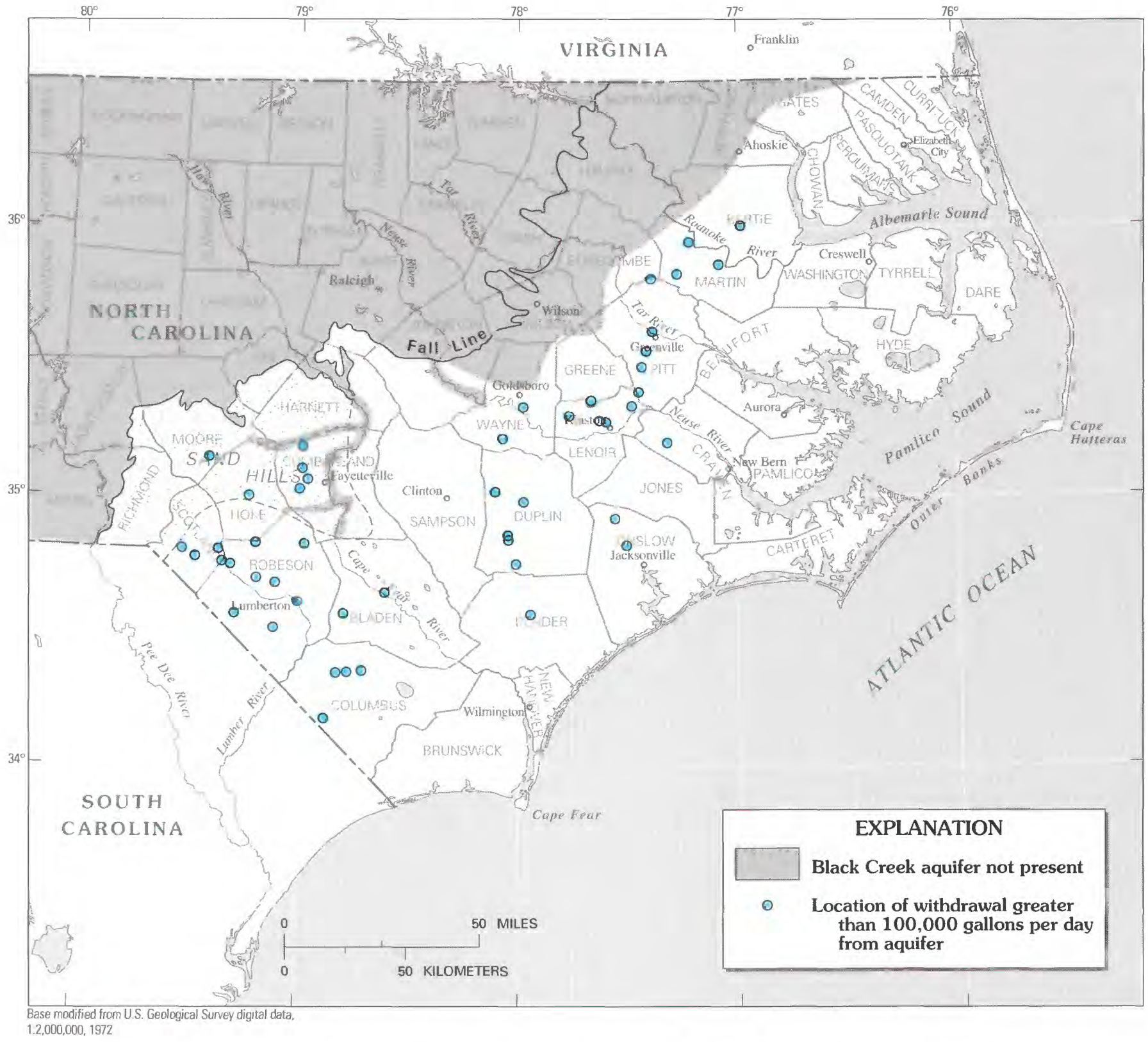

FigURE 61.-Locations of withdrawals greater than 100,000 gallons per day for the Black Creek aquifer (A4) for 1980. 


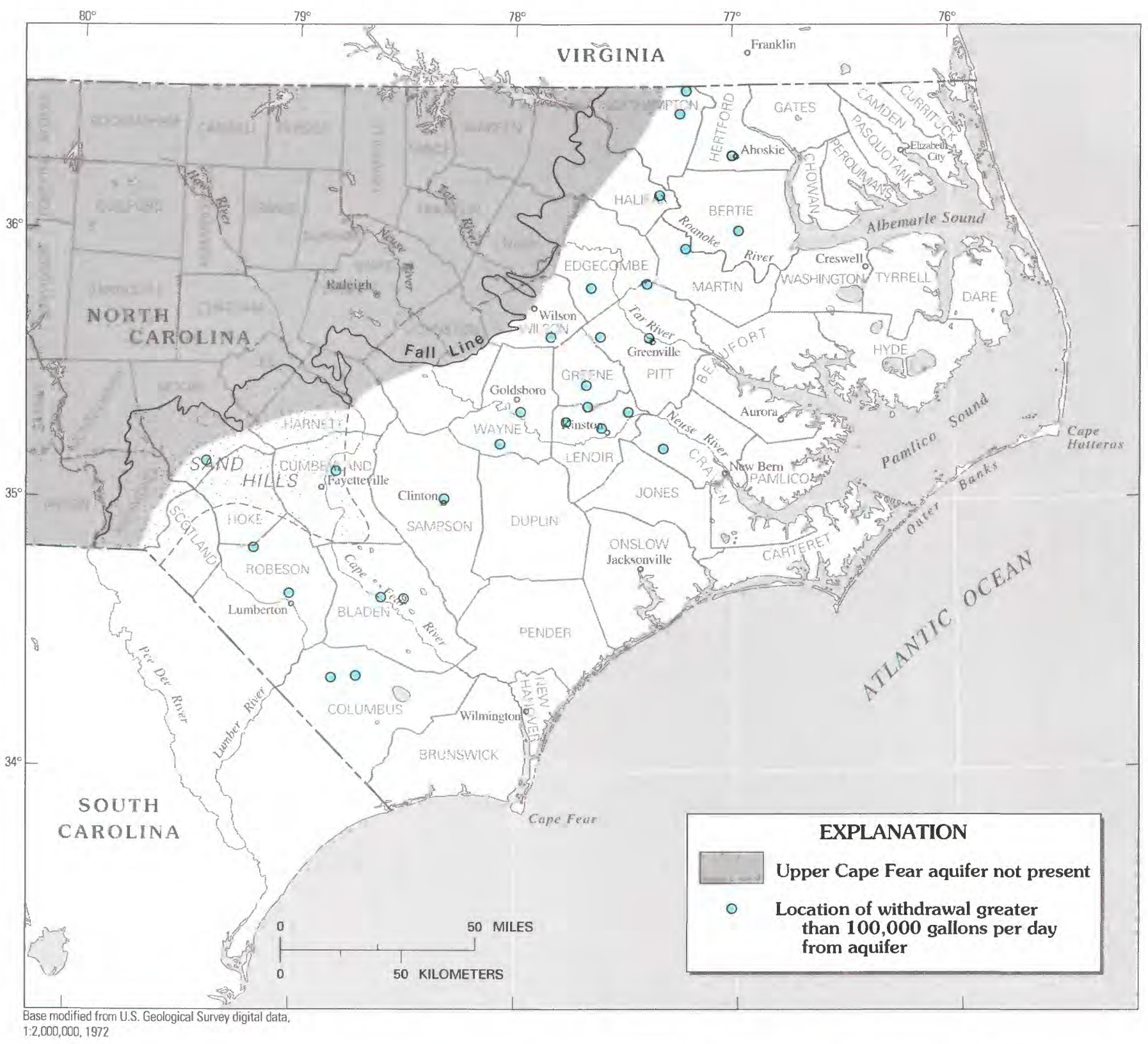

FIGURE 62.-Locations of withdrawals greater than 100,000 gallons per day for the upper Cape Fear aquifer (A3) for 1980. 


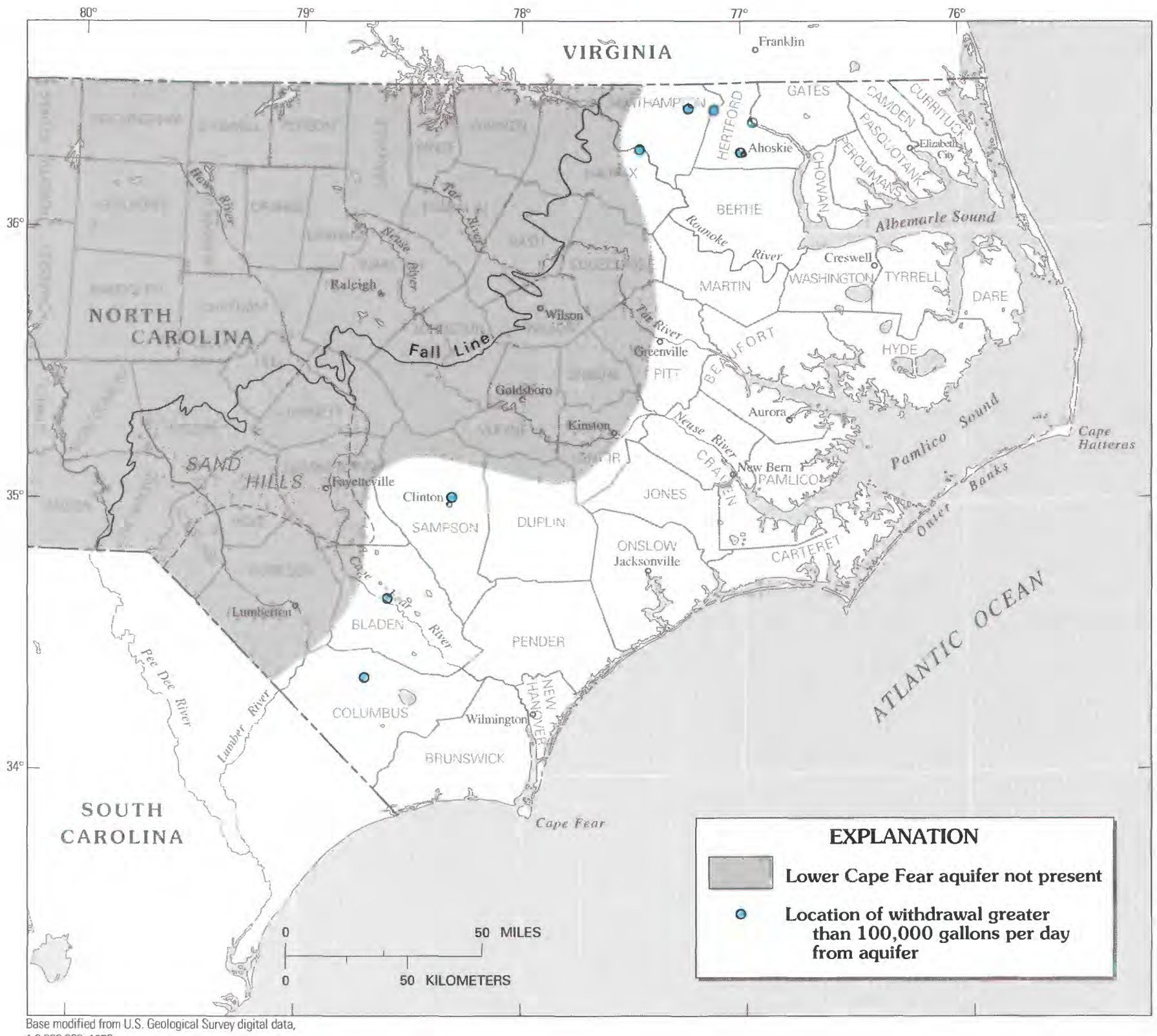

Base mocitied from U.S. Geological Survey digital data,

Figure 63.-Locations of withdrawals greater than 100,000 gallons per day for the lower Cape Fear aquifer (A2) for 1980. 
TABLE 2.-North Carolina ground-water pumpage by aquifer in 1980

\begin{tabular}{clc}
\hline $\begin{array}{c}\text { Model } \\
\text { layer } \\
\text { number }\end{array}$ & North Carolina aquifer & $\begin{array}{c}\text { 1980 pumpage } \\
\text { (millions of gallons } \\
\text { per day) }\end{array}$ \\
\hline A10 & Surficial & 0.3 \\
A9 & Yorktown & 2.9 \\
A8 & Pungo River & 1 \\
A7 & Castle Hayne & 136 \\
A6 & Beaufort & .1 \\
A5 & Peedee & 3.5 \\
A4 & Black Creek & 36.6 \\
A3 & Upper Cape Fear & 12.3 \\
A2 & Lower Cape Fear & 2.9 \\
A1 & Lower Cretaceous & 0 \\
Total pumpage & & 195.6 \\
\hline
\end{tabular}

\section{MODEL CALIBRATION}

\section{PROCEDURES}

Calibration of the North Carolina Coastal Plain ground-water flow model was a trial-and-adjustment procedure whereby model input was varied, and the resulting model output was compared with observed values. The process was repeated to minimize the difference between computed and observed values, until the computed results agreed with observed values to within some acceptable degree of accuracy. Generally, calibration was considered acceptable for purposes of this study when computed 1980 water levels were within $15 \mathrm{ft}$ of water levels measured in 1980.

A number of calibration simulations were made to determine how well the North Carolina Coastal Plain ground-water flow model was able to simulate actual records of water levels in both pumped and unpumped areas and to indicate where further adjustments to model parameters might be needed. Where calibration was judged inadequate, hydrogeologic, hydraulic head, and water-quality data were analyzed to determine the cause or causes. Often, poor initial estimates of model parameters were suspected of being the primary cause of poor water-level matches. Adjustments of the model parameters were made, and new simulations performed. Again, computed water levels were compared with observed values. Thus, an adjustment process involving several repetitions was employed in model calibration. The parameter most often adjusted was leakance of confining units $(T K)$, followed by transmissivity of the aquifers $(T)$. The other major hydraulic property represented in the model, storage coefficient $(S)$, was not varied during the calibration process because the model was found not to be sensitive to changes in the values of the storage coefficient. Other model parameters that were varied during the course of model calibration were the altitude of the water table, model-boundary fluxes, location of freshwater-saltwater boundaries, and pumping rates.

Large changes in leakance values from initial estimates (an order of magnitude or more) were considered justified because the vertical conductivity of confining units is not well known. However, changes in transmissivity were limited to no more than three times as much or no less than one-third as much as initial estimates because probable errors in initial estimates were much smaller than probable errors in estimates of leakance.

As a result of sensitivity analyses performed early in model calibration, it was found that changing transmissivity values produced large changes in computed heads near pumping centers, but away from pumping centers, changes were small. Changes in leakance of confining units also produced large changes in computed heads near pumping centers, but the changes away from pumping centers were often significant, too. If the computed water levels were too high or too low very near the pumping centers, but not elsewhere, a transmissivity problem was suspected. If computed water levels were found to be generally too high or too low in a given layer over a large area, a leakance problem was suspected. The vertical flow system was then examined to estimate what changes in model parameters would be most likely to result in better water-level matches, not only in the layer in question, but also in the underlying and overlying layers.

In selecting wells with water-level records for calibration purposes, areas were avoided that have experienced water-level declines very close to freshwatersaltwater boundaries $(10,000 \mathrm{mg} / \mathrm{L}$ chloride concentration). One model assumption is that the freshwater-saltwater boundary is a no-flow boundary. This assumption is not valid in areas where pumping may have induced flow of saltwater toward the pumping well, and it was felt that attempts to match hydrographs in such areas would be unrealistic. Full consideration of movement of saltwater requires a ground-water flow model capable of simulating waters of varying density and is beyond the scope of this study.

The assumption of no flow across the freshwatersaltwater boundaries is of particular concern in parts of aquifers A1 through A4 and part of A6, where simulated drawdowns near the freshwater-saltwater boundary commonly exceeded $10 \mathrm{ft}$ in 1980 . In these areas, actual drawdowns would likely be less than those simulated by the model. As a result, the confidence in model results (calibrated parameters) and predictions is less in these areas. The reader is referred to Leahy and Martin (1993) for a detailed discussion of the effect of the no-flow assumption for the freshwater-saltwater boundaries on the results of the regional ground-water flow model of the Northern Atlantic Coastal Plain. 
When testing model parameters during the course of model calibration, the usual procedure was to make three simulations. The first simulation was for steady-state prepumping conditions with water-table heads fixed at constant values, indicative of average long-term natural conditions. Boundary fluxes were provided by the regional model, which was frequently updated with refined flux values derived from each State subregional model.

Model output from this first simulation included flux between the water table and the topmost confined aquifer. This flux can be thought of as the deep percolation $(D P)$ term of equation 3 , which is the total ground-water recharge $(Q R E)$ minus base flow of streams $(B F)$.

The quantity $Q R E$ for each node was determined as described earlier in the "Model Input" section of the report. Subtracting or adding $D P$ to this value (depending on the direction of vertical flow) gave $B F$ for each node. When values were known also for the altitude of the water table, $h_{a}$, and the lowest stream altitude in each node, $h_{s}$, equation 2 could be solved for streambed leakance $(S L)$. An 11th (artificial) layer representing streams was then added to the model. The head at each stream node was set at the constant head, $h_{s}$, and the calculated value of $S L$ was used as the $T K$ value between the stream layer and the water-table layer. Recharge $(Q R E)$ was added to the surficial aquifer (A10), and a steady-state nonpumping simulation was made. The advantage of adding a layer representing streams is that, in later stressed simulations, the water levels are free to fluctuate within the surficial aquifer due to stresses either in the aquifer itself or in underlying aquifers. This results in a more realistic simulation of the surficial aquifer response to pumping stresses than in simulations where the water table is held constant.

A pumping simulation was then made, designed to simulate aquifer response to pumpage over the 10 pumping periods discussed above in the section "GroundWater Withdrawals and Time Discretization." Simulated hydrographs were compared with observed hydrographs for both prepumping and pumping conditions. A significant feature of the simulated hydrographs is that discretization error was reduced by computing heads at well locations, most of which are not at grid centers. This method of head computation involves solution of the common three-point problem, as shown in figure 64.

\section{RESULTS}

As previously mentioned, leakance ( $T K$ ) of confining units, was adjusted more often and to a greater degree than any other model parameter. Computed heads were found to be significantly sensitive to changes in this parameter. At the same time, large leakance adjustments of as much as two orders of magnitude could be justified in many instances because estimated initial values of this parameter were subject to more uncertainty than any other model parameter. Part of this uncertainty has to do with the difficulty in distinguishing silt from clay on geophysical logs, and part has to do with the discontinuity of some confining units, which often cannot be estimated from interpolation between geophysical logs collected at widely spaced locations.

Trial-and-adjustment model calibration indicated a general tendency for vertical hydraulic conductivity of confining units, $K_{v}$, to decrease with increasing depth and with increasing distance downdip. The tendency for the decrease with depth is reflected by minimum $K_{v}$ values in table 3 and is thought to be partly related to greater compaction of the silts and clays due to the greater weight of overlying sediments and the greater time for compaction. The tendency for decreasing $K_{v}$ with increasing distance downdip follows from this because, downdip, sediments of a given aquifer are generally more deeply buried, and there may also be a general downdip change from coarse clastic to fine clastic and marine facies (LeGrand, 1961). A countertendency to this decrease of $K_{v}$ with increasing depth and distance downdip may occur where nonmarine sediments are present, such as in large parts of the lowermost confining units CU1, CU2, and CU3. There, beds that make up the confining units are more likely to be discontinuous and, therefore, provide less resistance to vertical movement of water than suggested from the thickness of confining-unit material indicated on geophysical logs. Hence, model values of $K_{v}$ may be higher there (and elsewhere) than might be expected for silt or clay in order to reflect discontinuities.

Transmissivity $(T)$ was varied less often than leakance during model calibration. Initial estimates of $T$ were changed for three aquifers during the course of model calibration-the Castle Hayne aquifer (A7), the

TABLE 3.-Ranges of vertical hydraulic conductivity of confining units for the calibrated model

[Confining units defined in table 1 increase in depth from layer 9 to layer 1]

\begin{tabular}{lcc}
\hline $\begin{array}{l}\text { Model } \\
\text { layer } \\
\text { number }\end{array}$ & \multicolumn{2}{c}{$\begin{array}{c}\text { Vertical hydraulic conductivity of confining } \\
\text { units } K_{v} \text { (feet per day) }\end{array}$} \\
\cline { 2 - 3 } & Maximum values & Minimum values \\
\hline CU9 & $6.98 \times 10^{-3}$ & $6.82 \times 10^{-3}$ \\
CU8 & $7.94 \times 10^{-3}$ & $3.90 \times 10^{-3}$ \\
CU7 & $9.07 \times 10^{-4}$ & $3.01 \times 10^{-4}$ \\
CU6 & $5.88 \times 10^{-4}$ & $1.46 \times 10^{-4}$ \\
CU5 & $3.89 \times 10^{-4}$ & $7.71 \times 10^{-5}$ \\
CU4 & $2.77 \times 10^{-4}$ & $3.42 \times 10^{-5}$ \\
CU3 & 2.52 & $6.84 \times 10^{-6}$ \\
CU2 & $4.96 \times 10^{-1}$ & $4.13 \times 10^{-6}$ \\
CU1 & $2.88 \times 10^{-4}$ & $4.04 \times 10^{-5}$ \\
\hline
\end{tabular}




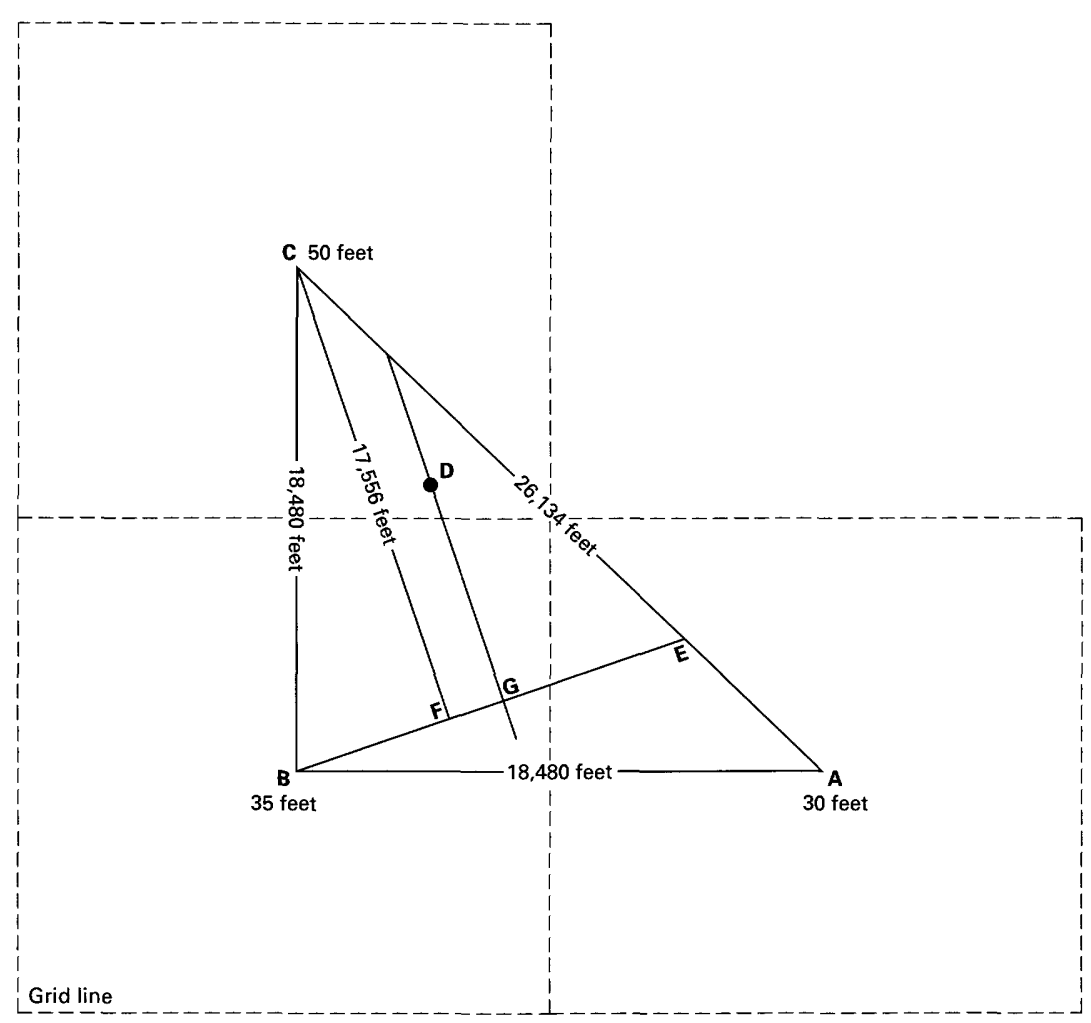

EXPLANATION

1. Locate three computed heads $(h)$ at grid nodes that form a triangle (ABC) enclosing an off-node point of interest (D).

2. Find the direction of ground-water flow and hydraulic gradient in the plane defined by the apexes of the triangle:

- Locate the triangle apex that has the intermediate water level (B).

- By linear interpolation, find the point on the side opposite (E) that has the same water level as $\mathbf{B}$.

- Draw line BE. This is a line of equal water level, $35 \mathrm{ft}$ (feet) in this case.

- Draw a line perpendicular to the equal water-level line (BE) that passes through either the apex of the higher or lower water levels. The resulting line (CF) represents the direction of the hydraulic gradient. Calculation of the gradient is as follows:

$$
\frac{h_{\mathrm{C}}-h_{\mathrm{E}}}{\text { distance CF }} \text {, or } \frac{50-35 \mathrm{ft}}{17,556 \mathrm{ft}}=0.00085 \text { foot per foot }
$$

3. Draw a line parallel to the direction of the gradient that passes through the point (D) at which the head is to be computed.

4. Measure distance from a point of known head $(\mathbf{G})$ to point at which head is to be calculated (line DG).

5 . Knowing the hydraulic gradient $(0.00085$ foot per foot), the head at point $\mathbf{G}$ $(35 \mathrm{ft})$, and the distance along flow path at DG $(8,316 \mathrm{ft})$, the head at point $\mathbf{D}\left(h_{\mathrm{D}}\right)$ may be calculated:

$$
\frac{h_{\mathrm{D}}-35 \mathrm{ft}}{8,316 \mathrm{ft}}=0.00085 ; \quad h_{\mathrm{D}}=42.07 \mathrm{ft}
$$

FIGURE 64.-Method of computing heads at off-node locations. 
TABLE 4.-Summary of differences between computed and observed water levels for December 31, 1980

[Values represent computed minus observed differences]

\begin{tabular}{|c|c|c|c|c|c|c|c|}
\hline \multirow{3}{*}{ Aquifer name } & \multirow{3}{*}{$\begin{array}{l}\text { Model layer } \\
\text { number }\end{array}$} & \multicolumn{6}{|c|}{ Average difference in water levels (feet) } \\
\hline & & \multicolumn{2}{|c|}{ All differences } & \multicolumn{2}{|c|}{ Positive differences only } & \multicolumn{2}{|c|}{ Negative differences only } \\
\hline & & $\begin{array}{l}\text { Number of } \\
\text { values }\end{array}$ & $\begin{array}{c}\text { Average } \\
\text { difference }\end{array}$ & $\begin{array}{l}\text { Number of } \\
\text { values }\end{array}$ & $\begin{array}{c}\text { Average } \\
\text { difference }\end{array}$ & $\begin{array}{l}\text { Number of } \\
\text { values }\end{array}$ & $\begin{array}{l}\text { Average } \\
\text { difference }\end{array}$ \\
\hline Yorktown & A9 & 27 & +1.4 & 16 & +4.5 & 11 & -3.4 \\
\hline Pungo River & A8 & 3 & +4.2 & 3 & +4.2 & 0 & - \\
\hline Castle Hayne & $\mathrm{A} 7$ & 47 & +2.4 & 32 & +7.3 & 15 & -7.8 \\
\hline Peedee & A5 & 28 & +0.2 & 12 & +11.2 & 16 & -8.1 \\
\hline Black Creek & $\mathrm{A} 4$ & 34 & -1.0 & 14 & +15.1 & 20 & -12.4 \\
\hline Upper Cape Fear & A3 & 30 & +7.3 & 21 & +13.5 & 9 & -7.3 \\
\hline Lower Cape Fear & $\mathrm{A} 2$ & 16 & -5.0 & 5 & +12.3 & 11 & -12.9 \\
\hline Lower Cretaceous & A1 & 1 & +14.8 & 1 & +14.8 & 0 & - \\
\hline
\end{tabular}

Black Creek aquifer (A4), and the upper Cape Fear aquifer (A3). Initial values of transmissivity for the Castle Hayne aquifer in Beaufort County, which were estimated from geophysical logs, gave computed heads that were tens of feet lower than observed heads. When transmissivity values were increased by a factor of 2.5 in that area, matches were much closer and were in better agreement with aquifer tests reported by DeWiest and others (1967). No attempt was made to calibrate for transmissivity values in the surficial aquifer (A10).

For the block representing the Castle Hayne aquifer (A7) at Lee Creek (row 28, column 37), modeled transmissivity was $41,200 \mathrm{ft}^{2} / \mathrm{d}$ for an aquifer thickness of about $340 \mathrm{ft}$ (inferred horizontal hydraulic conductivity is about $121 \mathrm{ft} / \mathrm{d}$ ). Values derived by DeWiest and others (1967, p. 94) from aquifer-test data indicate a higher transmissivity near Lee Creek of $52,100 \mathrm{ft} 2 / \mathrm{d}$ for an assumed formation thickness of $300 \mathrm{ft}$ (inferred hydraulic conductivity of $174 \mathrm{ft} / \mathrm{d}$ ). A limitation of the test reported by DeWiest and others (1967) is that the pumped well used in the test was open only to the top $44 \mathrm{ft}$ of the Castle Hayne aquifer. Such a test may not yield hydraulic conductivities representative of the entire aquifer thickness. Thus, the lesser hydraulic conductivity calibrated for the Castle Hayne aquifer near Lee Creek is not unreasonably low compared with values reported by DeWiest and others. Also, the transmissivity value for the Castle Hayne aquifer (A7) at Lee Creek derived from the model is very close to that derived by Sherwani (1973, p. 58) for the Lee Creek area $\left(40,100 \mathrm{ft}^{2} / \mathrm{d}\right)$ for use in his digital model.

A 50-percent reduction in $T$ from initial estimates everywhere in both the Black Creek aquifer (A4) and the upper Cape Fear aquifer (A3) resulted in generally better matches of computed heads with observed water levels. Apparently, silty clays interbedded with coarse sands in the deeply buried nonmarine and marginal-marine sediments of these aquifers were more effective in reducing the horizontal hydraulic conductivity, $K_{h}$, of the aquifer material than was first thought from examination of the geophysical logs (M.D. Winner, Jr., U.S. Geological Survey, oral commun., September 1985). Thus, initial estimates of $K_{h}$ were higher than final calibrated values.

A layer-by-layer summary of differences between observed and computed water levels for December 31, 1980 , is given in table 4 . The average difference between computed and observed water levels for 191 observation wells was slightly less than $+1.6 \mathrm{ft}$. Detailed comparisons of computed and observed values over time were also made. Nearly 240 computed hydrographs were compared with observed hydrographs. Figures 65 through 69 show selected hydrograph comparisons made during the course of model calibration. Those shown were chosen on the basis of length of record and a balanced geographic and aquifer distribution.

A number of poor matches of computed and observed water levels were attributed to discretization scale rather than to poor estimates of hydrologic parameters. For example, drawdowns due to pumpage are treated by the model as if water levels are drawn down evenly over an entire block, rather than as a cone of depression around a pumped well, and the three-point method illustrated in figure 64 does not completely correct for this where grid size is large. The coarse model grid makes errors from this source significant, particularly when computed values for a node are compared with values for an observation well located very close to a pumping well.

The scale of discretization is probably also responsible for several poor hydrograph matches in the Sand Hills area (fig. 1). Topographic relief and water-table gradients are greater in the Sand Hills region than in any 


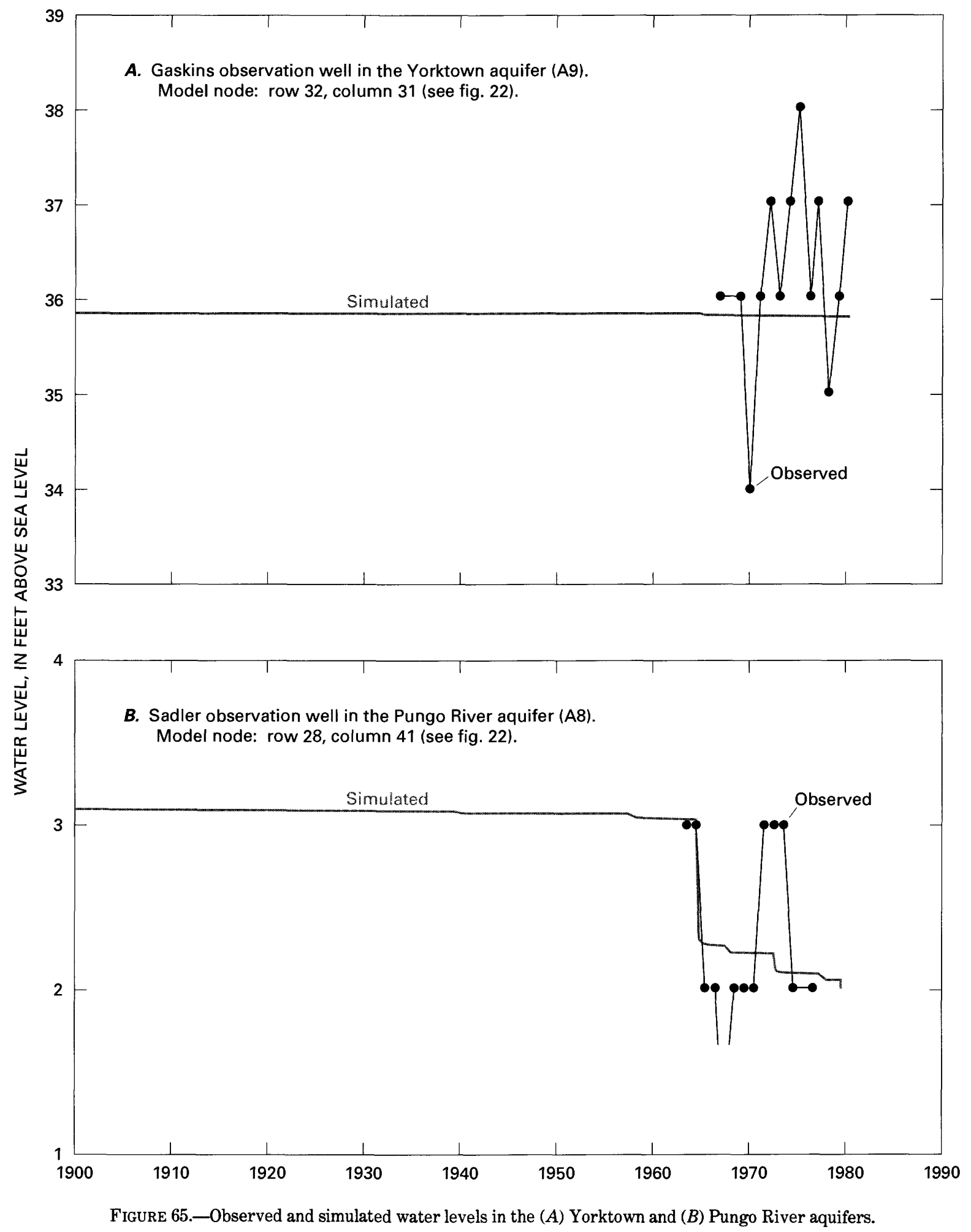




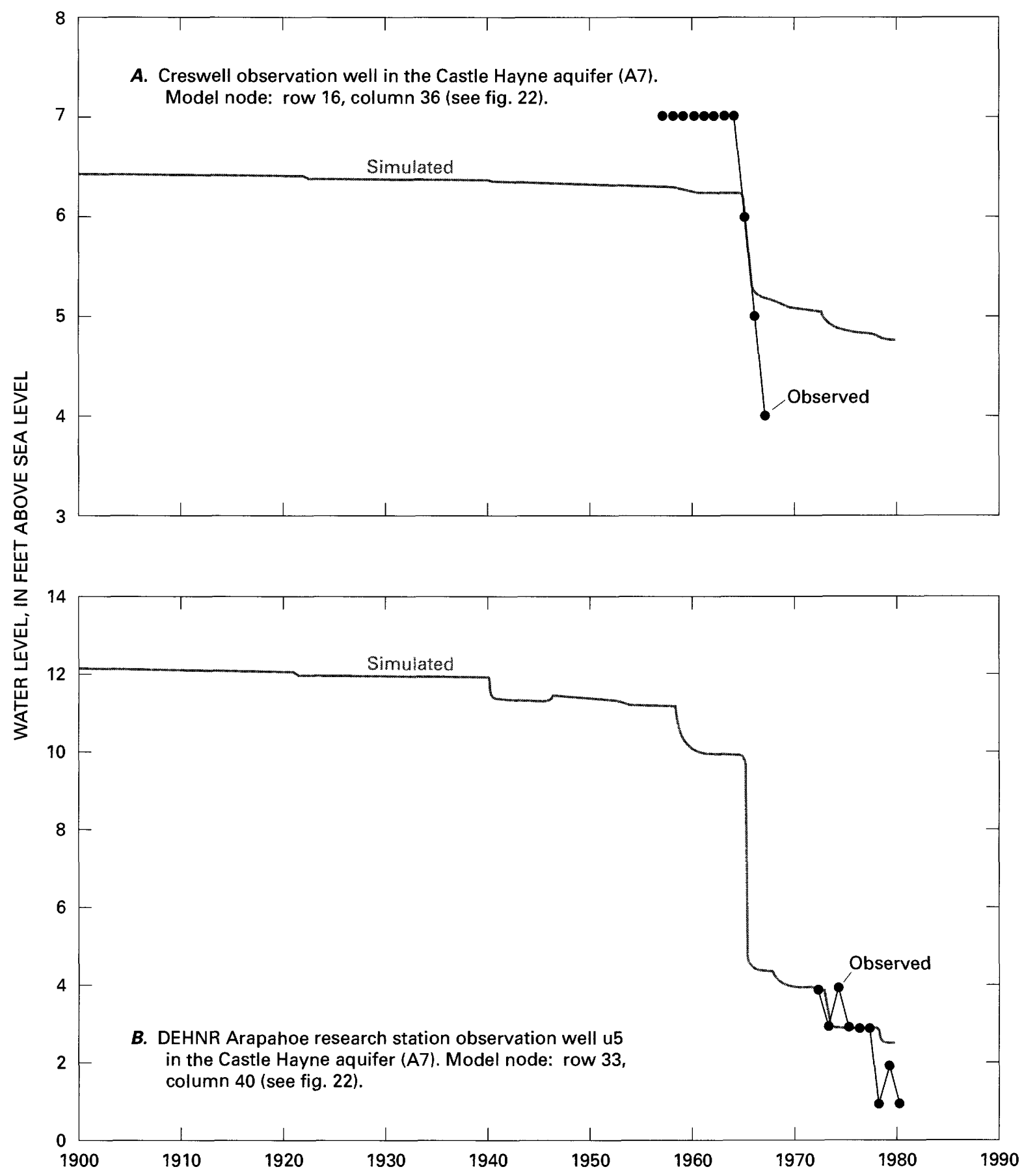

FIGURE 66.-Observed and simulated water levels in the Castle Hayne aquifer at $(A)$ the Creswell observation well and $(B)$ DEHNR (North Carolina Department of Environment, Health, and Natural Resources) Arapahoe research station observation well u5. 


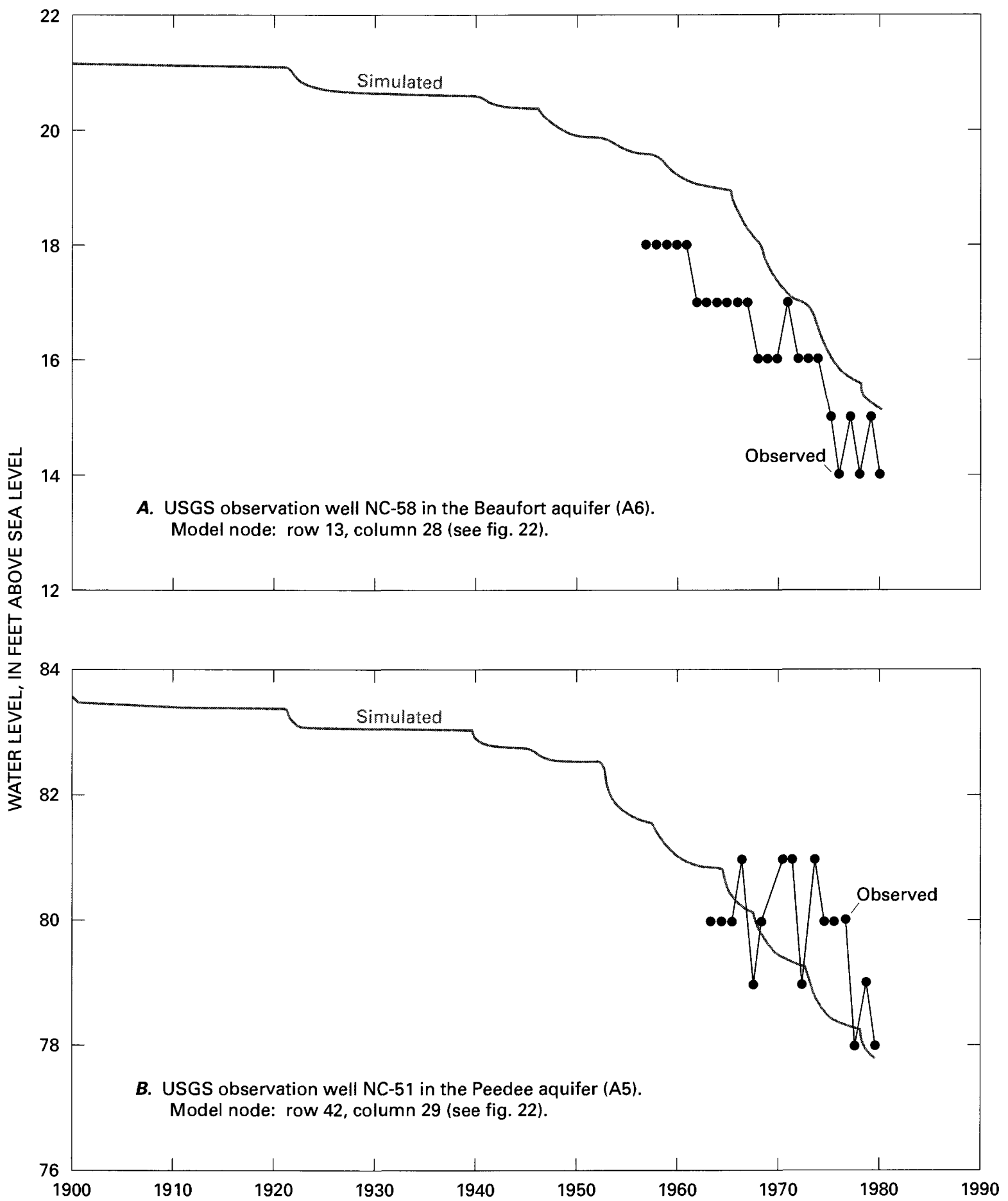

FIGURE 67.-Observed and simulated water levels in the $(A)$ Beaufort and $(B)$ Peedee aquifers. USGS, U.S. Geological Survey. 

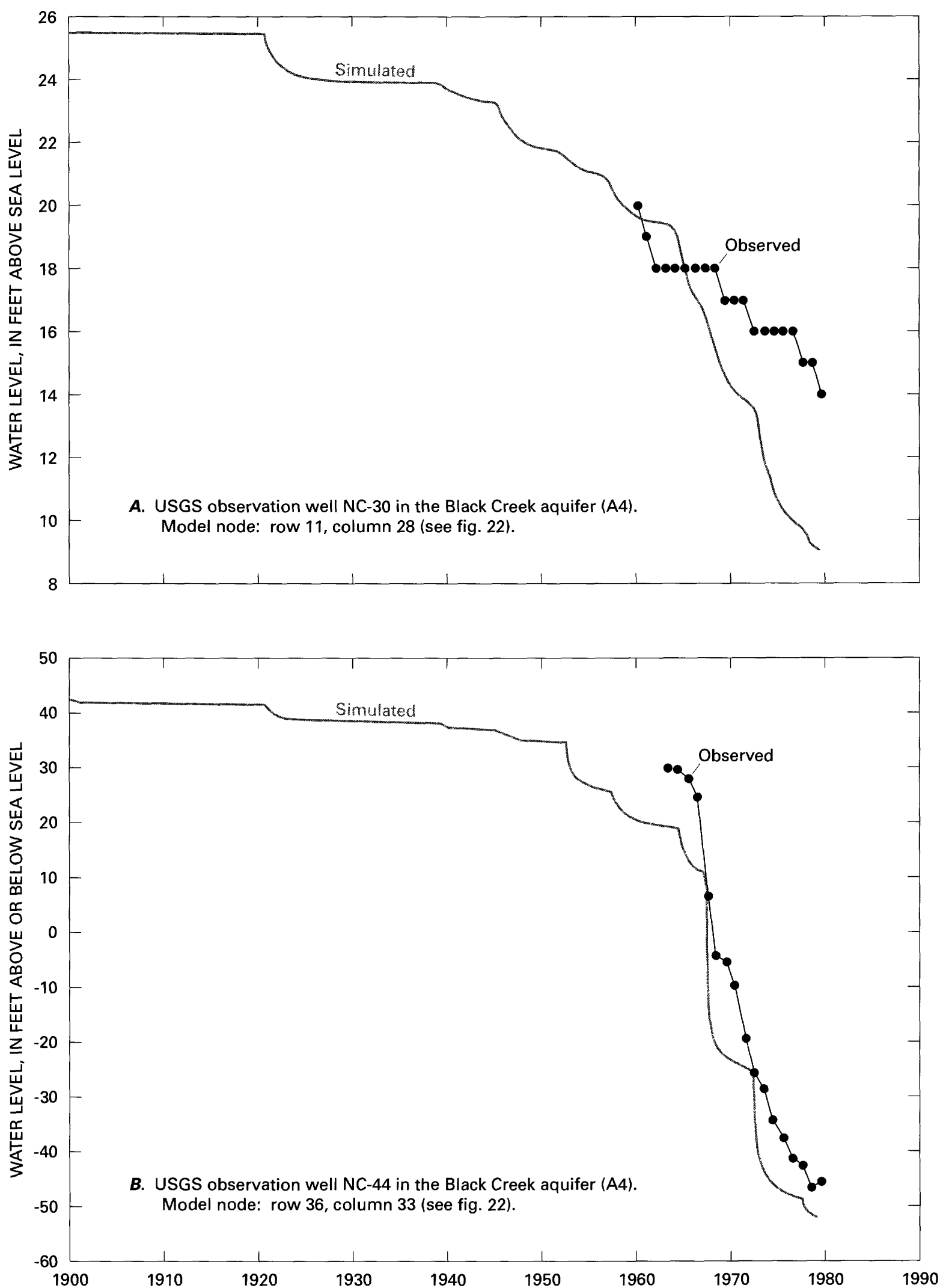

FIGURE 68.-Observed and simulated water levels in the Black Creek aquifer at USGS (U.S. Geological Survey) observation wells $(A) \mathrm{NC}-30$ and $(B)$ NC-44. 

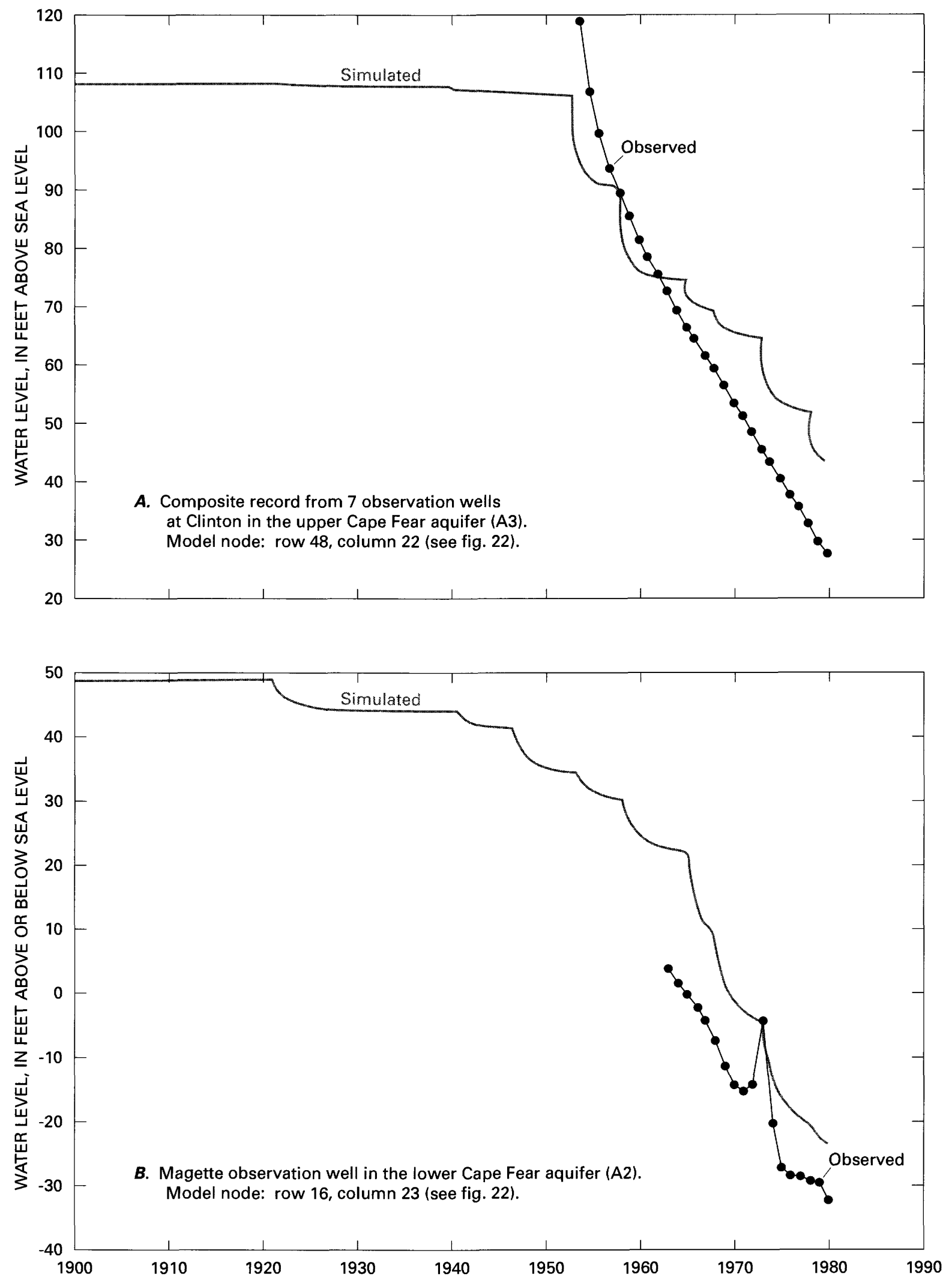

FIGURE 69.-Observed and simulated water levels in the $(A)$ upper Cape Fear and $(B)$ lower Cape Fear aquifers. 
other part of the North Carolina Coastal Plain, but the model grid is not fine enough to adequately reflect this variation. Thus, matches of computed with observed water levels were generally poor in this area, and the degree to which the model can be considered calibrated is much less for the Sand Hills region than for other parts of the North Carolina Coastal Plain. One practical consequence of this situation is that the accuracy of estimates of model parameters given by the flow model for the Sand Hills area is more uncertain than elsewhere. Future ground-water modeling studies of the Sand Hills region could obtain better results by utilizing a much finer model grid than that used in this study.

One measure of the degree to which the model can be considered calibrated is the density of calibration points that were used. By this criterion, the Castle Hayne aquifer (A7) would be considered the best calibrated layer (particularly near the large cone of depression centered just north of Aurora in Beaufort County), whereas the Lower Cretaceous, Beaufort, and Pungo River aquifers (A1, A6, and A8) would be the least well calibrated.

\section{SALTWATER REENTRANT IN THE CAPE FEAR ARCH}

An unusual landward reentrant of water containing high chloride concentrations (equal to or greater than $10,000 \mathrm{mg} / \mathrm{L}$ ) has been delineated in the Wilmington area by Winner and Coble $(1989,1996)$ in the upper and lower Cape Fear aquifers (A3 and A2). This reentrant is shown in this report in figures 32 and 33 by the northwestward bulge or point in the $10,000 \mathrm{mg} / \mathrm{L}$ chloride concentration line, which is considered to be a no-flow boundary in this study. The existence of the reentrant is supported by the work of LeGrand (1955), who described brackish water springs more than $20 \mathrm{ft}$ above sea level as far inland as Bladen County, and by Meisler (1989), who mapped the position of the saltwater in aquifers of the Northern Atlantic Coastal Plain. The reentrant overlies the Cape Fear arch, which is a broad southeast-trending uplift of both bedrock and the overlying sedimentary deposits of the Atlantic Coastal Plain (fig. 8). The axis of the uplift is marked approximately by the course of the lower Cape Fear River (fig. 2).

Trial simulations performed during model calibration indicated that some barrier to flow was needed to sustain the unusually high heads in the Cretaceous aquifers in extreme southeastern North Carolina (Peek and Register, 1975) and even higher heads further south along the South Carolina coast (Aucott and Speiran, 1985). A barrier might result from the aquifers having a lower transmissivity in the Cape Fear arch area than in surrounding areas. The juxtaposition of such a barrier over the arch suggests that the arch might have affected depositional patterns in the area during Cretaceous time, resulting in deposition of sediments of extremely low transmissivity, either with low hydraulic conductivity or near zero thickness, in the stratigraphic position of the upper and lower Cape Fear aquifers. However, data from the few wells in the arch area listed by Winner and Coble $(1989,1996)$ give indication of only small reductions in transmissivity of these two aquifers.

The lower Cape Fear aquifer (A2), which exhibits the highest heads, is slightly thinner on the northeast side of the Cape Fear arch than on the southwest side (fig. 8), but does not thin enough to cause a major change in transmissivity at this location. The upper Cape Fear aquifer (A3) has lower transmissivity on the northeast side of the arch than on the southwest side; this results from lower hydraulic conductivity in this area (Winner and Coble, 1989), not a decrease in thickness, as might be the case for the lower Cape Fear aquifer (A2). The trial simulations revealed that in order to sustain the high heads in the lower Cape Fear aquifer (A2) southwest of the arch, a no-flow or nearly no-flow boundary had to be present in the general area occupied by the saltwater reentrants shown in figures 32 and 33. Adjustment of transmissivity values of the lower Cape Fear aquifer (A2) over the arch to 50 percent or less of estimated values (fig. 33) resulted in little head buildup southwest of the arch.

Because there is no direct hydrogeologic evidence indicating a drastic change in the hydraulic conductivity or thickness of the upper and lower Cape Fear aquifers, it may be that the no-flow boundary results instead from the presence of dense water containing at least 10,000 $\mathrm{mg} / \mathrm{L}$ chloride over the Cape Fear arch. The confirmation of either idea (or other ideas) concerning the nature of the flow barrier (low-transmissivity sediments or saltwater) awaits further data and analyses for support.

\section{SENSITIVITY ANALYSIS}

Two types of applications of sensitivity analyses are appropriate in modeling studies. The first application is logically performed before model calibration to aid in data collection. If this analysis shows that the model is not sensitive to changes in certain parameters in part of the modeled area, efforts to improve parameter estimates there would not improve the simulation capability of the model. Conversely, if the initial sensitivity analysis shows that the model is sensitive to changes in a particular parameter in an area, data-collection activities and analyses to better define or verify the parameter values in that area could result in improved simulation capability. 
TABLE 5.-Range of perturbed values for transmissivity and leakance

\begin{tabular}{lccc}
\hline \multicolumn{1}{c}{ Value } & Group 1 & Group 2 & Group 3 \\
\hline \multicolumn{4}{c}{ Transmissivity (feet squared per day) } \\
\hline Mean & 2,994 & 1,758 & 33,030 \\
10 percent of mean & 299 & 176 & 3,303 \\
190 percent of mean & 5,688 & 3,340 & 62,757 \\
\hline \multicolumn{4}{c}{ Leakance (per day) } \\
\hline Mean & $3.8 \times 10^{-5}$ & $2.3 \times 10^{-2}$ & $4.8 \times 10^{-3}$ \\
10 percent of mean & $3.8 \times 10^{-6}$ & $2.3 \times 10^{-3}$ & $4.8 \times 10^{-4}$ \\
190 percent of mean & $7.2 \times 10^{-5}$ & $4.37 \times 10^{-2}$ & $9.12 \times 10^{-3}$ \\
\hline
\end{tabular}

A second application is performed after calibration to evaluate the relation between parameter variability and model response. This is an indication of the extent to which calibration is likely to have improved parameter estimates and may be a guide in the design of parameter-estimation efforts for future modeling studies. The following sections discuss this second application of the sensitivity analysis during this study.

\section{METHOD OF ANALYSIS}

The model response investigated in the sensitivity analysis was hydraulic head. The parameters selected for testing were transmissivity, storage coefficient of aquifers, and leakance of confining units. Transmissivity and leakance values were varied by plus and minus 50 percent and plus and minus 90 percent of their estimated values. Storage coefficient was varied by plus and minus 90 percent of its estimated value.

To minimize computer time required for the analysis of transmissivity and leakance, steady-state simulations utilizing 1980 pumpage values were made. However, as in transient simulations performed for calibration purposes, streams were simulated as a constant-head layer, and the surficial aquifer (A10) was simulated as a free surface receiving recharge. Tests showed that heads computed in this manner were similar to 1980 heads computed by transient simulations, indicating that steady-state simulations made as a part of the sensitivity analysis would provide results similar to transient simulations. However, transient simulations (1900-80) were made to analyze the effects of varying storage coefficient because these results are more time dependent.

To simplify the sensitivity analysis, the aquifers and confining units were lumped into three groups of hydrologically similar flow systems. Group 1 consisted of the Peedee (A5), Black Creek (A4), upper Cape Fear (A3), lower Cape Fear (A2), and Lower Cretaceous (A1) aqui-
TABLE 6.-Range of perturbed values for storage coefficient

\begin{tabular}{lc}
\hline \multicolumn{1}{c}{ Value } & All groups \\
\hline \multicolumn{2}{c}{ Confined aquifer (dimensionless) } \\
\hline Mean & $1.0 \times 10^{-4}$ \\
10 percent of mean & $1.0 \times 10^{-5}$ \\
190 percent of mean & $1.9 \times 10^{-4}$ \\
\hline \multicolumn{1}{c}{ Unconfined aquifer (dimensionless) } \\
\hline Mean & $1.5 \times 10^{-1}$ \\
10 percent of mean & $1.5 \times 10^{-2}$ \\
190 percent of mean & $2.8 \times 10^{-1}$ \\
\hline
\end{tabular}

fers, which are the sand aquifers in Cretaceous rocks. Group 2 contained the Yorktown (A9), Pungo River (A8), and Beaufort (A6) aquifers, sand aquifers in Tertiary rocks, and, when analyzing aquifer parameters, the surficial aquifer (A10). When analyzing a confining-unit parameter, the surficial aquifer (A10) was not included. Group 3 was solely the Castle Hayne aquifer (A7), which is primarily limestone and sand of Tertiary age. Parameters were perturbed and analyzed for each group. The exception was storage coefficient; for this parameter, all model layers were perturbed and analyzed simultaneously.

\section{RESULTS}

Tables 5 and 6 list the mean values (calibrated values) and maximum and minimum values of the parameter variations for the three aquifer groups for transmissivity, leakance, and storage coefficient. Within each of the three aquifer groups, the results of the sensitivity analysis were categorized, and statistics were generated separately for each category. These categories are (1) all active nodes, (2) nodes where pumpage occurred (pumpage nodes), (3) nodes with no flow in a laterally adjacent node, (4) nodes with constant flux in a laterally adjacent node, and (5) nodes with constant head in a vertically adjacent node (category 5 is found only in the surficial aquifer (A10) in group 2). If a given node fell into more than one category, the node was omitted from the analysis in all but the active-node category. The overall results of the sensitivity analysis are summarized in table 7.

Table 7 indicates a general tendency for the Cretaceous sand aquifers (group 1) to exhibit a greater degree of head variation for a given percentage change in model parameter than the other groups. This is mainly attributed to group 1 nodes representing the deep Cretaceous aquifers with the least hydraulic contact with the surficial aquifer (A10). The surficial aquifer is resistant to 
TABLE 7.-Results of sensitivity analysis

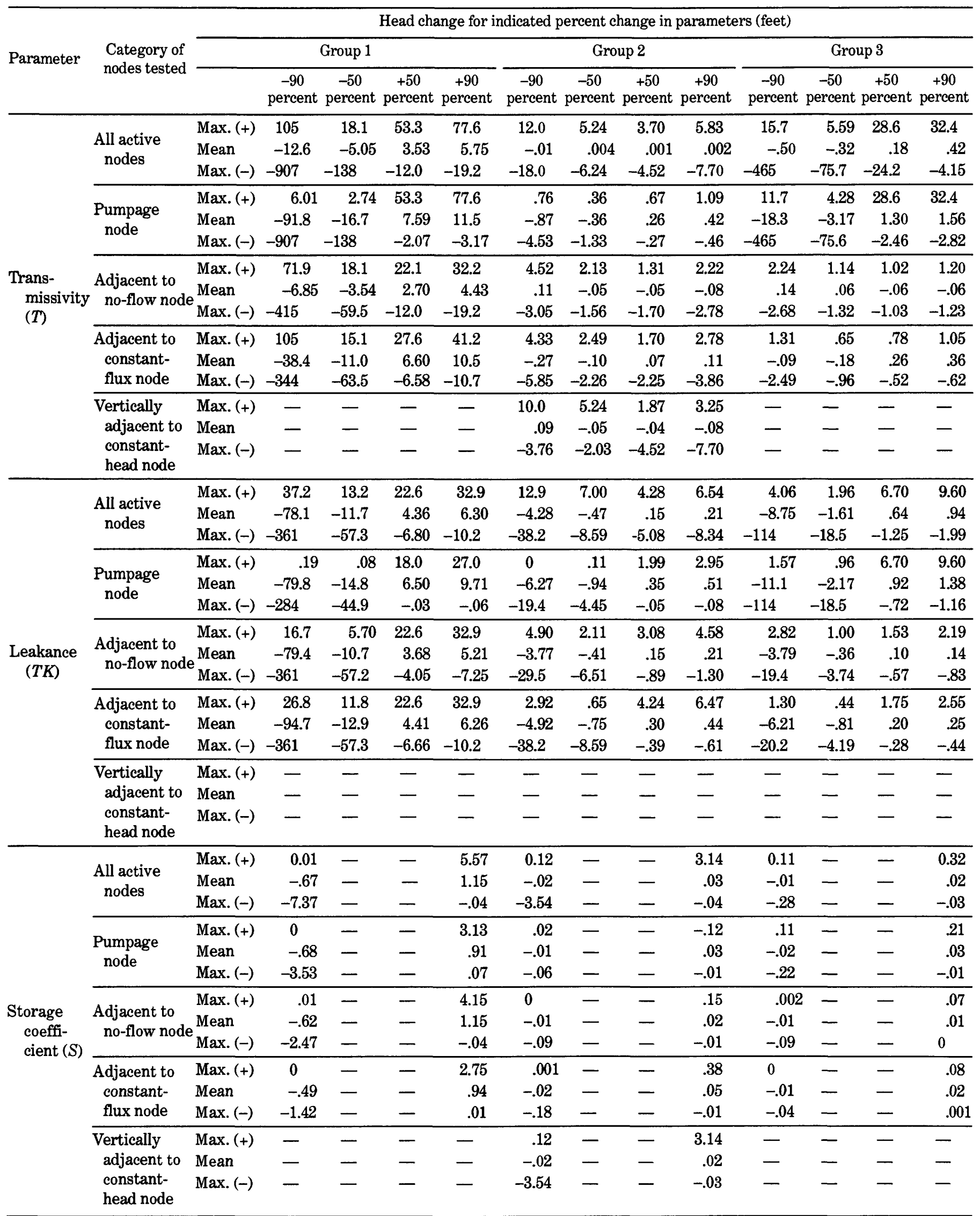


changes in head for several reasons. First, being unconfined, it has a much larger storage coefficient than the lower confined aquifers. Second, in the various simulation schemes described earlier, it either receives direct recharge in large amounts or the water table is treated as a constant-head surface. Normally, most of this recharge goes to stream nodes and only a small amount recharges the deeper aquifers. However, if the water levels in the surficial aquifer start to decline, less of this recharge will go to streams, and more is available to sustain the water level in the surficial aquifer and recharge the deeper aquifers. Further, if the water level is drawn down below stream levels, then the streams recharge the surficial aquifer. Thus, the surficial aquifer and those aquifers in close hydraulic contact with it tend to show the least sensitivity to changes in model parameters. Table 7 also indicates that pumpage nodes are the most sensitive to parameter changes. This indicates that future studies on ground-water flow modeling could best concentrate parameter estimation efforts in areas being pumped.

Generally, the model was found to be highly sensitive to changes in transmissivity and leakance near pumping centers. Away from pumping centers, the model was only slightly sensitive to transmissivity changes but moderately sensitive to changes in leakance (compare mean values for head changes for all active nodes for transmissivity and leakance in table 7).

The greatest head difference in the sensitivity analysis was for transmissivity in the Cretaceous aquifers (group 1), where a decrease in head of more than $900 \mathrm{ft}$ occurred at one pumping node in the Black Creek aquifer (A4) when transmissivity was reduced by 90 percent (fig. $70 \mathrm{~A}$ ). Increases in transmissivity and leakance (figs. $70 \mathrm{~A}$ and $70 B$ ) produced smaller head changes than similar percentage decreases in these parameters, whereas increases in storage coefficient (fig. $70 \mathrm{C}$ ) produced similar or sometimes greater changes in head than corresponding decreases.

Results of sensitivity analyses on other subregional models in the Northeastern Atlantic Coastal Plain were similar to the type of model responses reported here. Some effects of parameter changes studied in the sensitivity analyses of Virginia and New Jersey were not studied in North Carolina, such as confining-unit storage, position of the freshwater-saltwater no-flow boundary, boundary fluxes, and recharge (Harsh and Laczniak, 1990; Martin, 1990, in press). However, because of the similarity of the models, similar responses might be expected for the North Carolina model.

In New Jersey and Virginia, confining-unit storage was shown to be important to simulation of the system when the response of confining units is in the range of inelastic deformation. The Virginia and New Jersey mod- els were not sensitive to the position of the freshwater-saltwater no-flow boundary. However, unlike North Carolina, these States have no significant pumpage affecting areas near the freshwater-saltwater no-flow boundary. The New Jersey model was sensitive to boundary flux near the boundaries but was not sensitive to boundary fluxes two or three nodes away from the boundaries. The Virginia and New Jersey models' insensitivity to recharge was similar to that for the North Carolina flow model. Results indicate that all the models were not sensitive to changes in recharge rate to the surficial aquifer in transient simulations, because streambed leakance was increased or decreased to move more or less water into streams to balance increases or decreases in recharge (refer to "Streambed Leakance" section of report under "Model Input").

\section{HYDROLOGIC ANALYSIS OF THE AQUIFER SYSTEM}

\section{WATER BUDGET}

Most aspects of the overall ground-water flow system have not changed significantly from predevelopment conditions in 1900 to development conditions in 1980. The only major change on the system during that time interval has been initiation and continued increase of ground-water withdrawals. Pumpage in North Carolina and in nearby southeastern Virginia has altered the overall water budget very little, although local effects are significant. Pumpage from large areas in North Carolina increased from zero before 1900 to 302 cubic feet per second $\left(\mathrm{ft}^{3} / \mathrm{s}\right)(195 \mathrm{Mgal} / \mathrm{d})$ in 1980 , which is only about 1.2 percent of the average recharge to the ground-water system of $25,703 \mathrm{ft}^{3} / \mathrm{s}$ (table 8 ).

Simulation results indicate that pumpage from the ground-water system over time is ultimately compensated for largely by reduced flow to streams. Reduction in flow to streams between 1900 and 1980 over the entire North Carolina Coastal Plain, shown as constant-head discharge from the system in table 8 , was $297 \mathrm{ft}^{3} / \mathrm{s}$ and, although not large in relation to the total of the average flow of all the Coastal Plain streams, could locally be a significant percentage of dry-weather streamflow in some streams.

Major changes in the amount of water withdrawn from wells (fig. 54 and table 8 ) have resulted in changes in contributions from ground-water storage as favorable hydraulic gradients are established toward pumping centers. When these gradients are established and if there is sufficient recharge, a new equilibrium condition will be reached in which contributions from storage to pumpage will be negligible. Significant withdrawals from the sand aquifers in rocks of Cretaceous age began during 1940- 

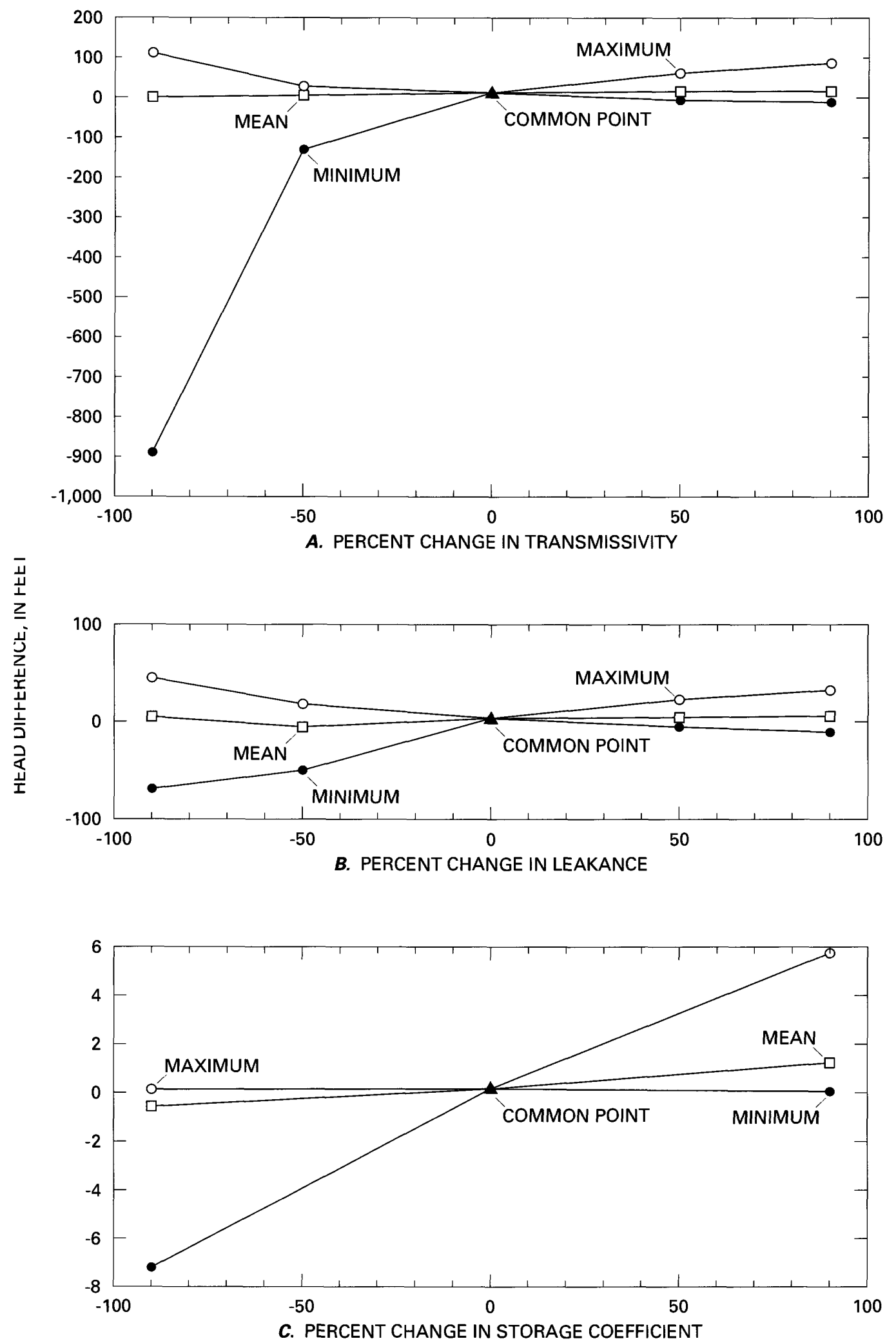

FigURE 70.-Head differences in Cretaceous sand aquifers (group 1) due to changes in ( $A$ ) group 1 transmissivity, $(B)$ group 1 leakance, and $(C)$ model-wide storage coefficient. 
TABLE 8.-Summary of model-computed water budgets for the ground-water flow system of the North Carolina Coastal Plain, 1900-2000

\begin{tabular}{|c|c|c|c|c|c|c|c|c|c|}
\hline \multirow{3}{*}{$\begin{array}{l}\text { Pumping } \\
\text { period }\end{array}$} & \multirow{3}{*}{ Date } & \multicolumn{8}{|c|}{ Flow rates to $(+)$ and from $(-)$ flow system at end of pumping period (cubic feet per second) } \\
\hline & & \multirow{2}{*}{$\begin{array}{l}\text { Change } \\
\text { in storage }\end{array}$} & \multirow{2}{*}{ Recharge } & \multicolumn{2}{|c|}{ Specified flux } & \multirow{2}{*}{ Pumping } & \multicolumn{2}{|c|}{ Constant head } & \multirow{2}{*}{$\begin{array}{c}\text { Difference } \\
\text { between } \\
\text { inflow and } \\
\text { outflow }\end{array}$} \\
\hline & & & & To system & From system & & To system & From system & \\
\hline Prepumping & Pre-1900 & 0 & $+25,703$ & +10 & -15.0 & 0 & +0.5 & $-25,701$ & -2.5 \\
\hline 1 & $\begin{array}{l}\text { January } 1,1900- \\
\text { December } 31,1920\end{array}$ & -.1 & $+25,703$ & +10 & -15.3 & -4.7 & +.5 & $-25,697$ & -3.6 \\
\hline 2 & $\begin{array}{l}\text { January } 1,1921- \\
\text { December } 31,1939\end{array}$ & +.2 & $+25,703$ & +8 & -15.3 & -11.8 & +.5 & $-25,688$ & -3.4 \\
\hline 3 & $\begin{array}{l}\text { January } 1,1940- \\
\text { December } 31,1945\end{array}$ & +4 & $+25,703$ & +8 & -32.9 & -16.1 & +.5 & $-25,670$ & -3.5 \\
\hline 4 & $\begin{array}{l}\text { January 1, 1946- } \\
\text { December 31, } 1952\end{array}$ & +6 & $+25,703$ & +7 & -18.4 & -62.6 & +1.5 & $-25,641$ & -4.5 \\
\hline 5 & $\begin{array}{l}\text { January } 1,1953- \\
\text { December } 31,1957\end{array}$ & +7 & $+25,703$ & +7 & -18.8 & -77.2 & +2.1 & $-25,627$ & -3.9 \\
\hline 6 & $\begin{array}{l}\text { January 1, 1958- } \\
\text { December 31, } 1964\end{array}$ & +6 & $+25,703$ & +7 & -20.7 & -125.3 & +14.9 & $-25,588$ & -3.1 \\
\hline 7 & $\begin{array}{l}\text { January } 1,1965- \\
\text { December } 31,1967\end{array}$ & +20 & $+25,703$ & +7 & -34.5 & -197.5 & +3.6 & $-25,504$ & -2.4 \\
\hline 8 & $\begin{array}{l}\text { January } 1,1968- \\
\text { December } 31,1972\end{array}$ & +14 & $+25,703$ & +8 & -28.8 & -242.2 & +4.0 & $-25,460$ & -2.0 \\
\hline 9 & $\begin{array}{l}\text { January } 1,1973- \\
\text { December } 31,1977\end{array}$ & +14 & $+25,703$ & +8 & -36.7 & -275.3 & +5.7 & $-25,422$ & -3.3 \\
\hline \multirow[t]{2}{*}{10} & $\begin{array}{l}\text { January 1, 1978- } \\
\text { December 31, } 1980\end{array}$ & +14 & $+25,703$ & +8 & -36 & -294 & +5.9 & $-25,404$ & -3.1 \\
\hline & Simulated year 2000 & +26 & $+25,703$ & +8 & -21 & -531 & +42.1 & $-25,229$ & -1.9 \\
\hline
\end{tabular}

45. At that time, contributions from storage amounted to several cubic feet per second. During 1965-67, withdrawals from the Castle Hayne aquifer (A7) increased, and storage contributions increased to $20 \mathrm{ft}^{3} / \mathrm{s}$. During 196880 , the contributions from storage resulting from withdrawals from the Castle Hayne aquifer were small as equilibrium was again established, but increased withdrawals elsewhere, primarily in sand aquifers in rocks of Cretaceous age, resulted in total contributions from storage of about $14 \mathrm{ft}^{3} / \mathrm{s}$.

Pumpage has changed ground-water movement within the system, but change in the recharge to and discharge from the system has been slight. The average recharge rate of $25,703 \mathrm{ft}^{3} / \mathrm{s}$ was calculated as a constant over the simulation period. Natural discharge from the system as base flow to streams and discharge to the sounds decreased slightly from 25,701 to $25,404 \mathrm{ft}^{3} / \mathrm{s}$ from pre-1900 to 1980 , a decrease of $297 \mathrm{ft}^{3} / \mathrm{s}$, or less than 1.2 percent of the total recharge. Pumpage was mainly supplied by this diversion. The change in natural discharge of $297 \mathrm{ft}^{3} / \mathrm{s}$ is very close to the rate of pumping during the 1978-80 pumping period $\left(294 \mathrm{ft}^{3} / \mathrm{s}\right)$. The excess decrease in natural discharge of $3 \mathrm{ft}^{3} / \mathrm{s}$ is mostly due to effects of pumpage in adjacent States, primarily Virginia.
The principal change in the ground-water flow system of the North Carolina Coastal Plain primarily involves vertical movement of water from one layer in the system into another in and around those areas where the major pumping is taking place. The changes in direction of vertical flow are shown by a series of maps presented in a following section of this report.

Loss of ground-water storage is sensitive to the rate of pumping increase. Rate of loss of storage was greatest $\left(20 \mathrm{ft}^{3} / \mathrm{s}\right)$ during 1965-67, when withdrawals increased an average of about $24.1 \mathrm{ft}^{3} / \mathrm{s}$ per year. Since then, the contribution from storage has remained at $14 \mathrm{ft}^{3} / \mathrm{s}$ as withdrawal increases have been fairly constant, averaging about $7.4 \mathrm{ft}^{3} / \mathrm{s}$.

Simulated ground-water flow across the Virginia and South Carolina borders changed significantly from 1900 to 1980 . The most dramatic change was across the Virginia line, where $3.8 \mathrm{ft}^{3} / \mathrm{s}$ flowed from Virginia to North Carolina in 1900; by 1980, ground-water flow was from North Carolina to Virginia at a rate of $24.7 \mathrm{ft}^{3} / \mathrm{s}$. This change occurred in the lower Cape Fear aquifer (A2) and, to a lesser extent, in the upper Cape Fear (A3) and Lower Cretaceous aquifers (A1). The change results from pumpage mainly from the lower Cape Fear aquifer 
(A2) and Lower Cretaceous aquifer (A1) at Franklin, Va., which is about $25 \mathrm{mi}$ north of Ahoskie, N.C.

Flow from North Carolina to South Carolina was 7.1 $\mathrm{ft}^{3} / \mathrm{s}$ in 1900 , and this decreased slightly to $6.4 \mathrm{ft}^{3} / \mathrm{s}$ in 1980. This decrease is attributed to pumpage in the southern Coastal Plain of North Carolina from the Black Creek (A4) and lower Cape Fear (A2) aquifers. A slight lowering of the potentiometric surfaces of these two aquifers in North Carolina decreased the hydraulic gradient toward South Carolina.

A model simulation was made for the year 2000 under the assumption that pumping would increase by 3 percent per year from 1981 to 2000 . Under these conditions, contributions from storage would nearly double, from 14 to $26 \mathrm{ft}^{3} / \mathrm{s}$ (table 8 ), as cones of depression in the sand aquifers of Cretaceous age would continue to increase in size, and contributions from streams (induced infiltration) would increase more than sevenfold from those of 1980 from 5.9 to $42.1 \mathrm{ft}^{3} / \mathrm{s}$. Ground-water discharge to streams would continue but at a very slightly decreased rate.

\section{POTENTIOMETRIC SURFACES}

Although changes in the overall water budget for the Coastal Plain aquifers due to pumping were minor during 1900-80, pumping has caused large local decreases in the potentiometric surfaces of several aquifers. In order to show the changes in the potentiometric surfaces of the 10 aquifers, maps are presented for the simulated prepumping conditions (1900), for 1980 conditions, and for assumed pumping conditions in the year 2000.

Simulated prepumping potentiometric surfaces are shown for the 10 aquifers in figures 71 through 80 . The figures also show available observed values of water levels for the late 1800 's and early 1900 's in unpumped areas. Many of these water-level observations were taken from Clark and others (1912) and from unpublished drillers' records from that era. In some instances, modern water levels are shown in these figures and were assumed to represent prepumping conditions in aquifers unaffected by pumping, such as for the lower Cape Fear aquifer (A2) (fig. 79) in the southern part of the Coastal Plain. The potentiometric surfaces for the surficial aquifer (A10) and for the updip (western) parts of all the other aquifers are high in the interstream divide areas and low in the valleys of perennial streams. This distribution indicates that for these aquifers in these areas, most ground-water movement is within local flow systems, and most ground-water discharge is to the nearby streams. In the downdip areas of confined aquifers, the Yorktown through Lower Cretaceous aquifers (A9-A1), the potentiometric surfaces have a gentle coastward gradient to the east-southeast.
Simulated potentiometric surfaces for 1980 (figs. 8190 ), when compared with 1900 prepumping potentiometric surfaces (figs. 71-80), indicate lowered water levels in parts of most aquifers due to pumping. Notably, drawdowns of more than $135 \mathrm{ft}$ and $90 \mathrm{ft}$ occurred in parts of the Lower Cretaceous (A1) and lower Cape Fear (A2) aquifers, respectively, near the Virginia border. These drawdowns were due largely to pumpage at Franklin, Va. (compare fig. 80 with fig. 90 and fig. 79 with fig. 89 ). Drawdowns of more than $60 \mathrm{ft}, 125 \mathrm{ft}$, and $110 \mathrm{ft}$ occurred in parts of the lower Cape Fear (A2), upper Cape Fear (A3), and Black Creek (A4) aquifers, respectively, in the central Coastal Plain in and around Greenville, Kinston, and Jacksonville, N.C. These drawdowns were due to several large withdrawals in the area; the large cone of depression associated with these withdrawals is most evident in figure 87.

Drawdowns of more than $30 \mathrm{ft}$ and $60 \mathrm{ft}$ occurred in parts of the Beaufort (A6) and Castle Hayne (A7) aquifers, respectively, in the Beaufort County area. Here, the drawdowns were caused in large part by withdrawals from the Castle Hayne aquifer (A7) in connection with open-pit phosphate-mining operations and a chemical plant near Aurora (fig. 58); the cone of depression associated with these withdrawals is most evident in figure 84 . A noteworthy aspect of the drawdown in the Beaufort aquifer (A6) is that no water was withdrawn directly from this aquifer at the mine and chemical plant. Withdrawals from the overlying Castle Hayne aquifer (A7) caused water to move upward through the Beaufort confining unit (CU6) in such quantities as to create a large area of depressed potentiometric levels in the Beaufort aquifer (A6) (fig. 85).

The simulated 1980 water level in the Castle Hayne aquifer (A7) near Aurora was slightly more than $50 \mathrm{ft}$ below sea level, whereas measured water levels in some wells were greater than $100 \mathrm{ft}$ below sea level in the withdrawal area. This difference in simulated and measured water levels results from the large block size used in the flow model. There, the simulated average water level over the $12.25-\mathrm{mi}^{2}$ block area was at least $50 \mathrm{ft}$ higher than measured water levels in the center of the cone of depression.

The Peedee aquifer (A5) also showed a decline of about $15 \mathrm{ft}$ between 1900 and 1980 in the Aurora area (figs. 76 and 86). As with the Beaufort aquifer (A6), the Peedee aquifer has no major withdrawals in this area, and its water-level decline is similarly attributed to the effect of the large cone of depression in the overlying Castle Hayne aquifer (A7).

Text continues on p. M110. 


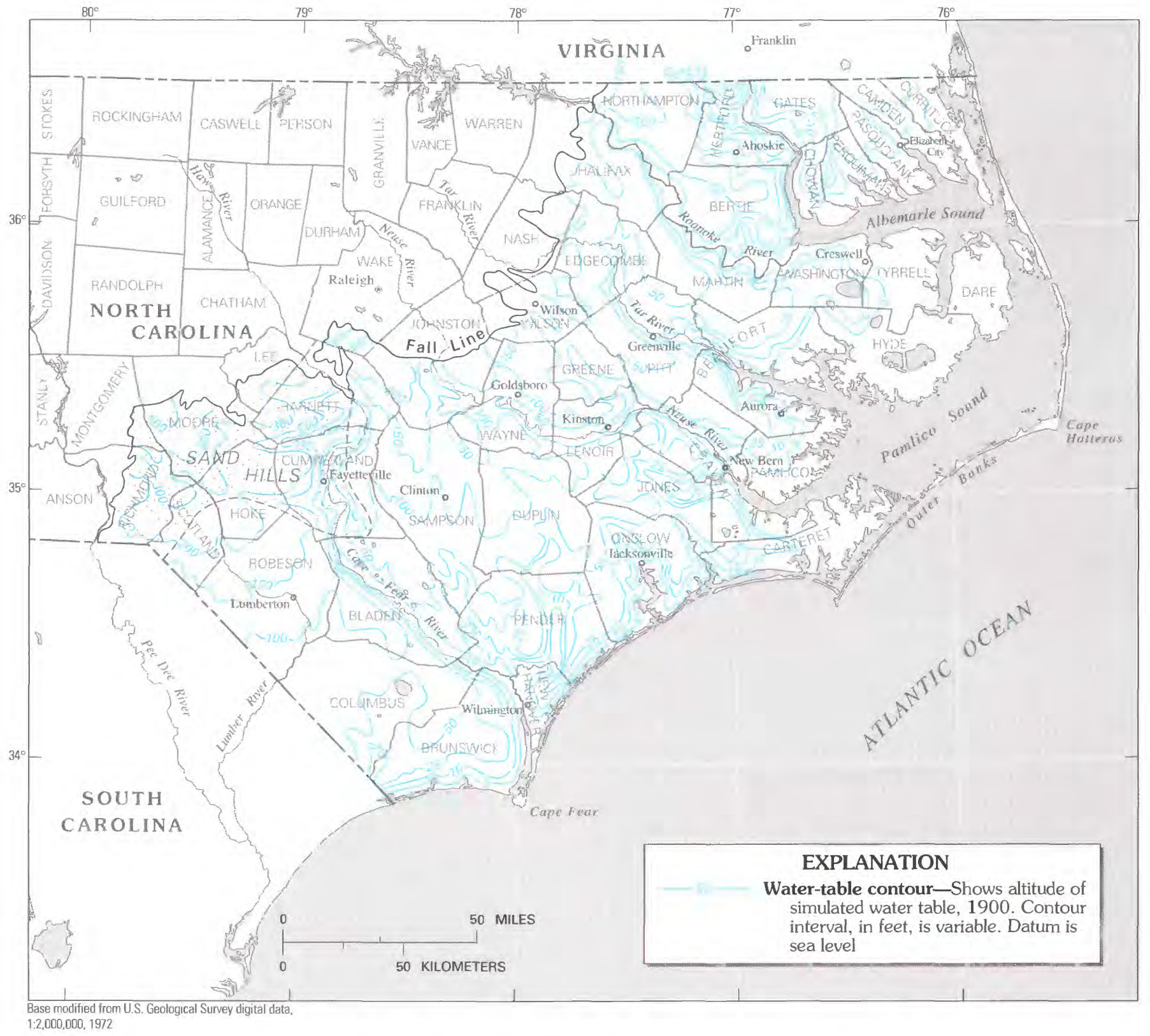

Figure 71.-Simulated prepumping (1900) water table for the surficial aquifer (A10). 


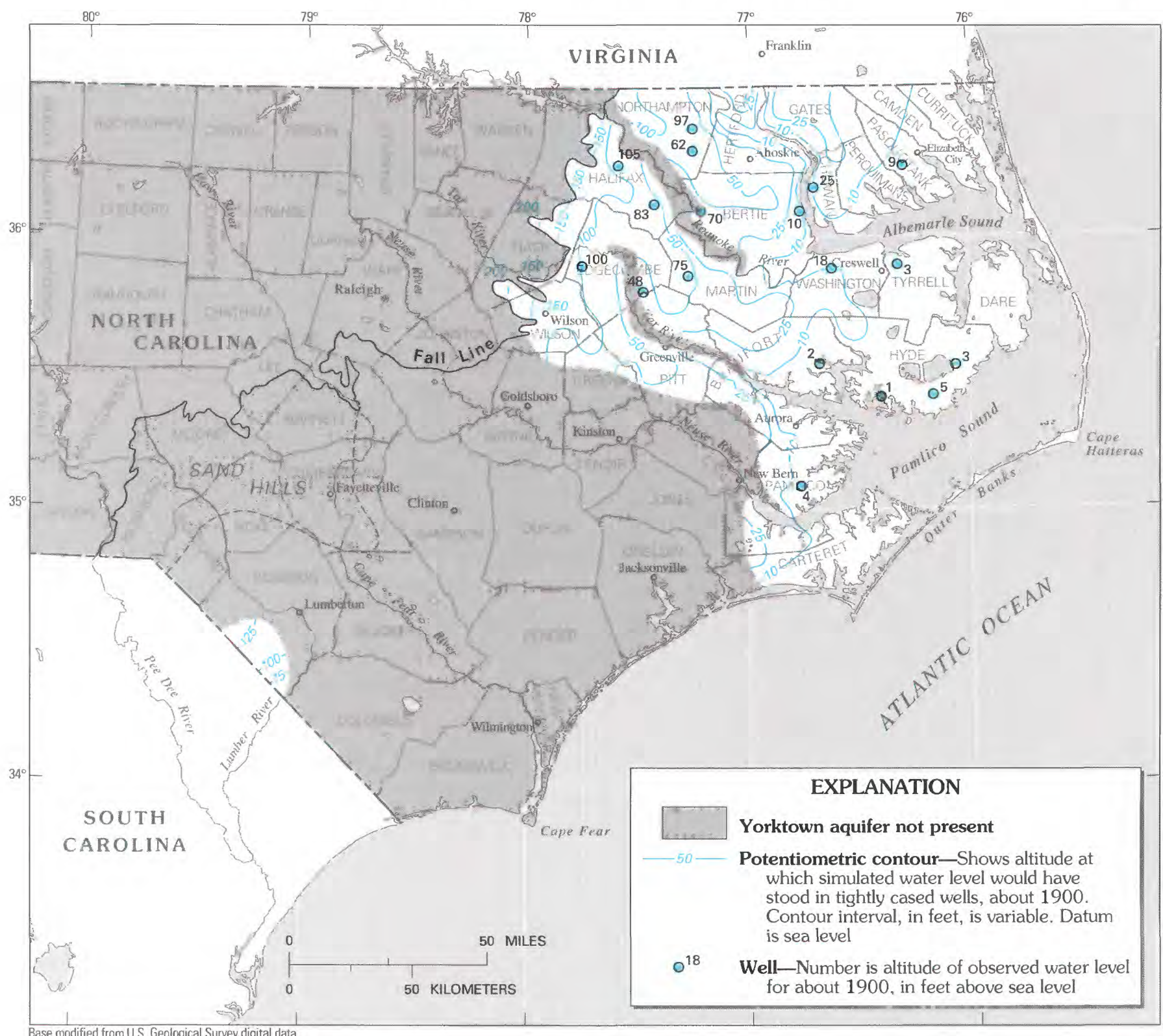

Base modified from U.S. Geological Survey digital data,

FigURE 72.-Simulated prepumping (1900) potentiometric surface for the Yorktown aquifer (A9). 


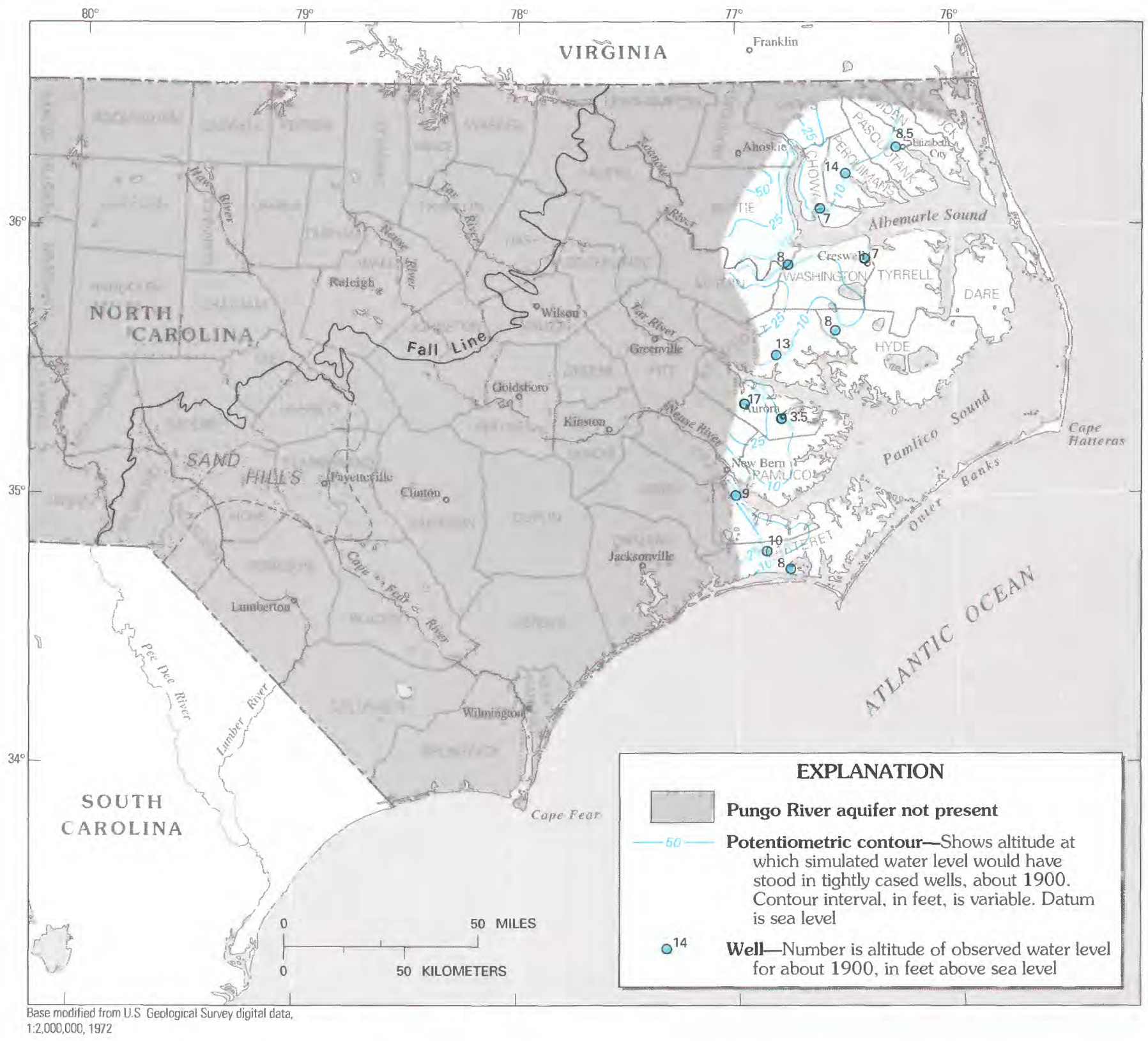

FIGURE 73.- Simulated prepumping (1900) potentiometric surface for the Pungo River aquifer (A8). 


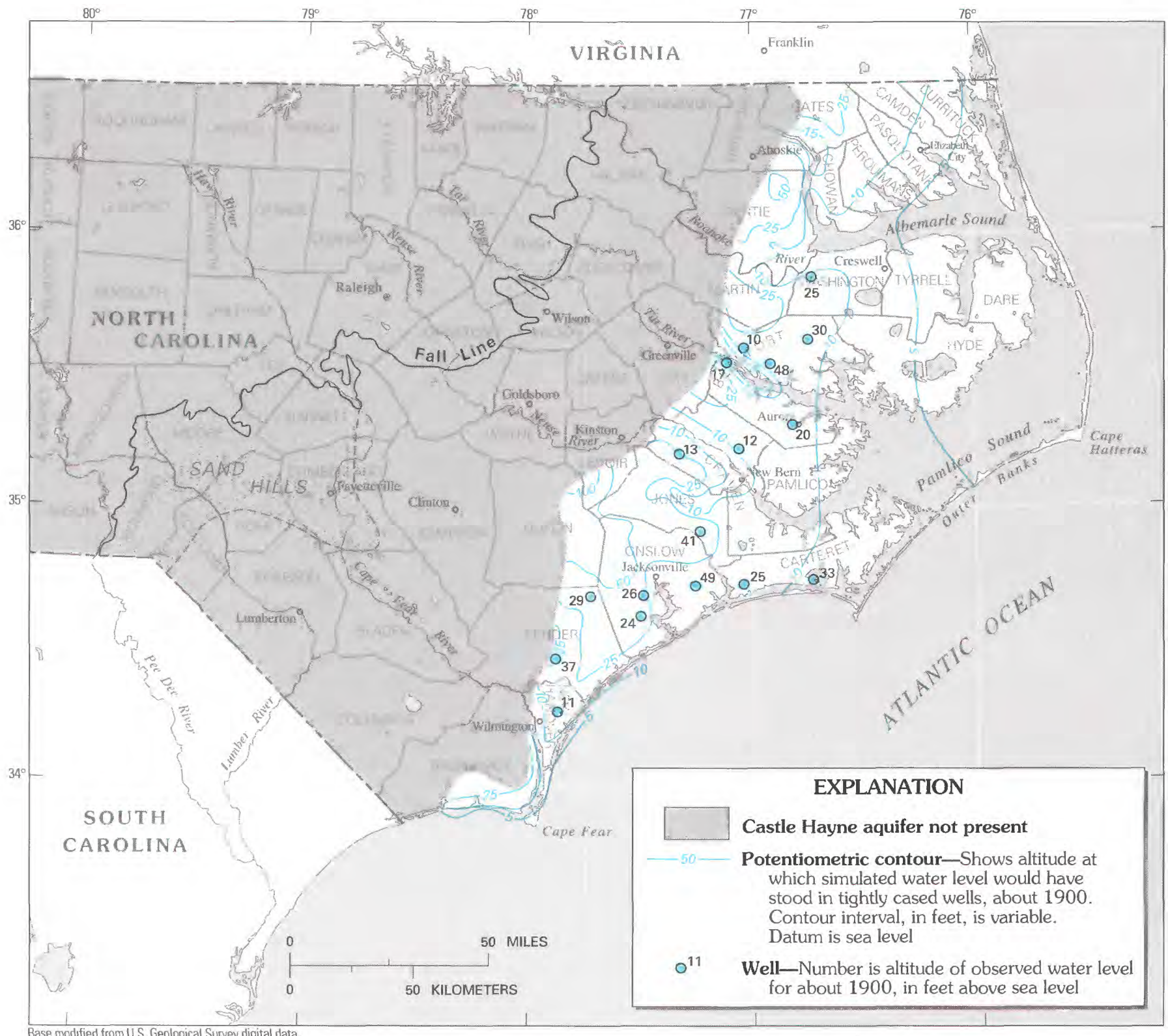

Base moditied from U.S. Geological Survey digital data.

FigURE 74.-Simulated prepumping (1900) potentiometric surface for the Castle Hayne aquifer (A7). 


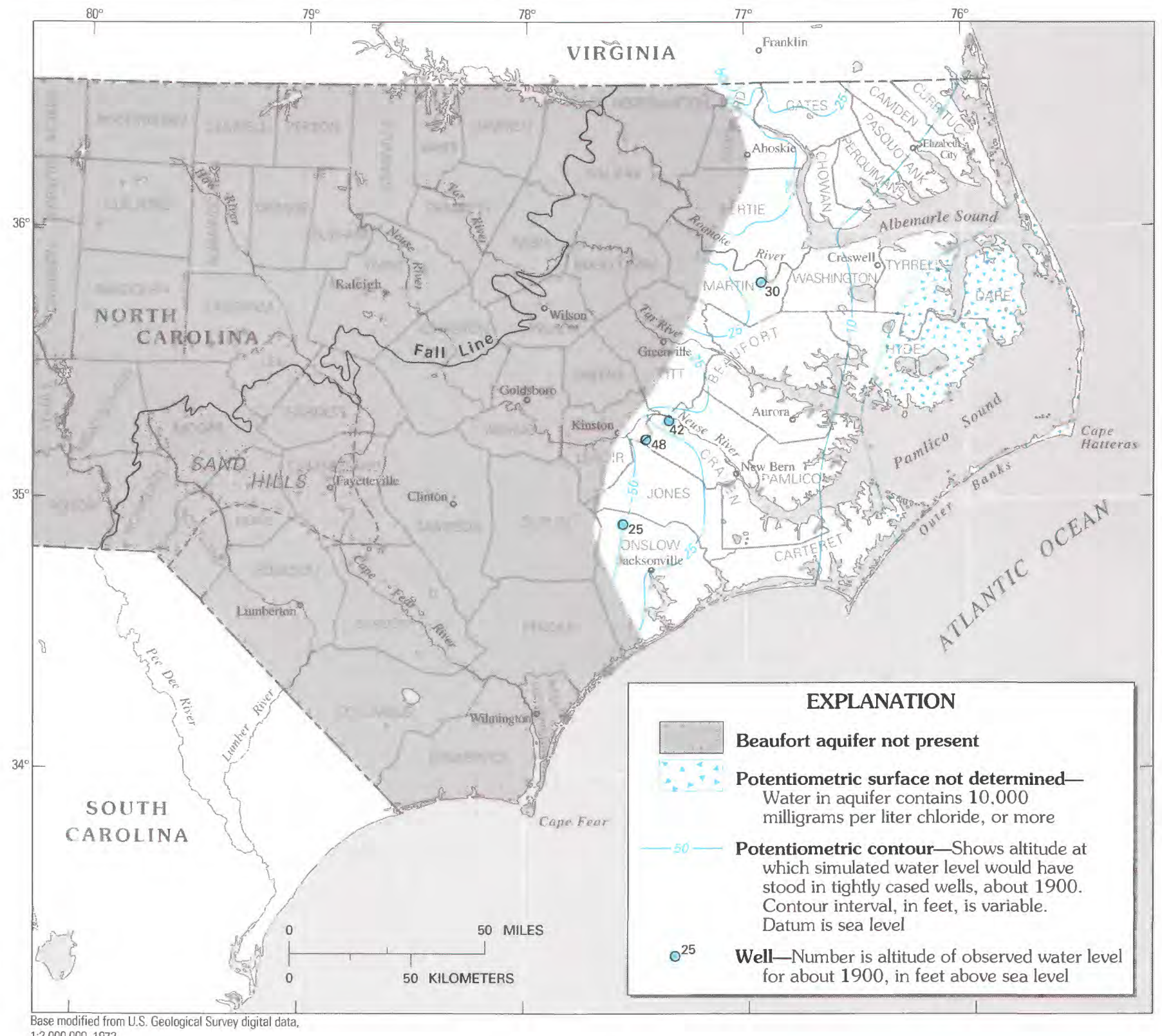

$1: 2,000,000,1972$

FIGURE 75. Simulated prepumping (1900) potentiometric surface for the Beaufort aquifer (A6). 


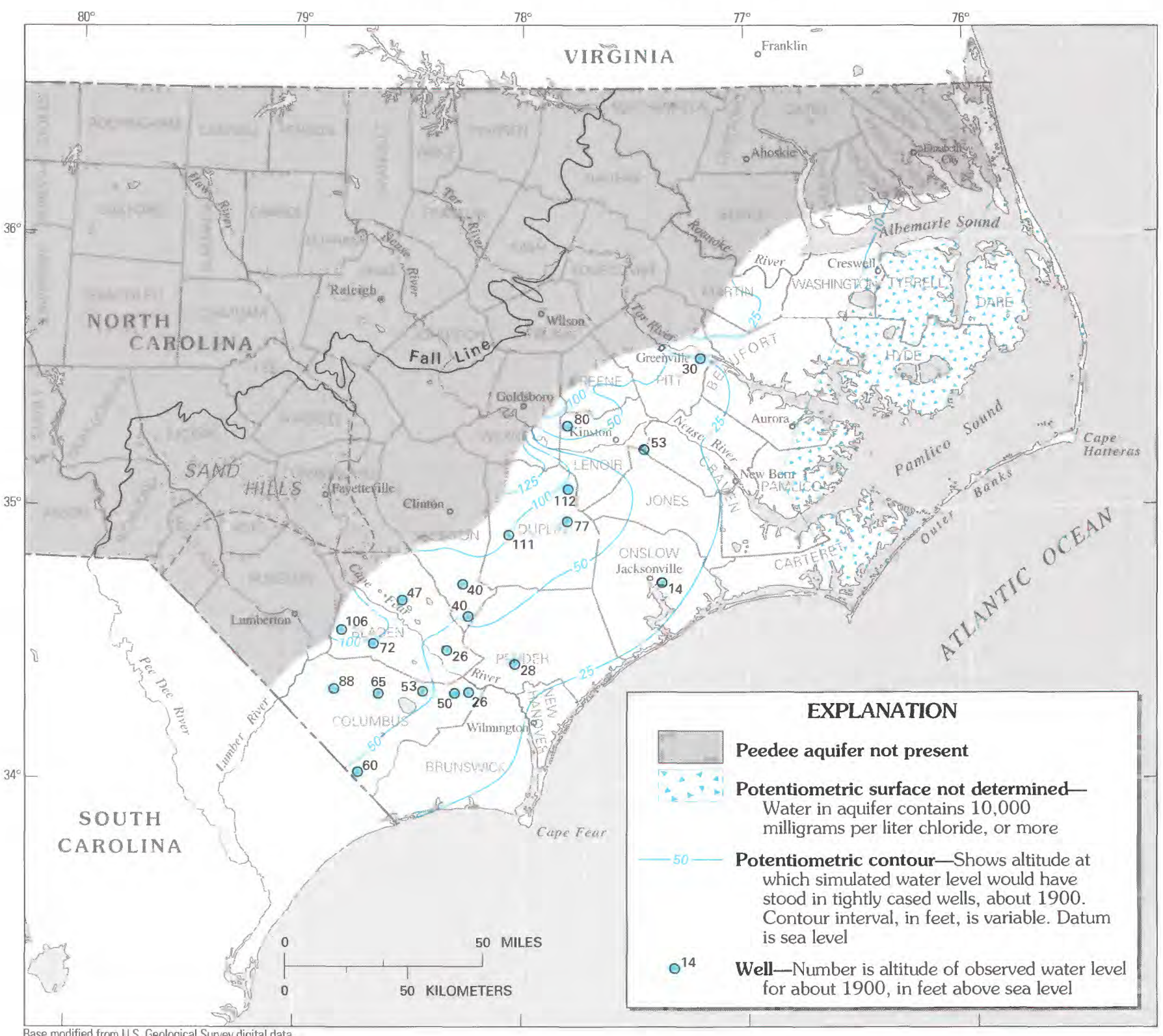

Base modified from U.S. Geological Survey digital data,

1:2,000,000, 1972

FIGURE 76- Simulated prepumping (1900) potentiometric surface for the Peedee aquifer (A5). 


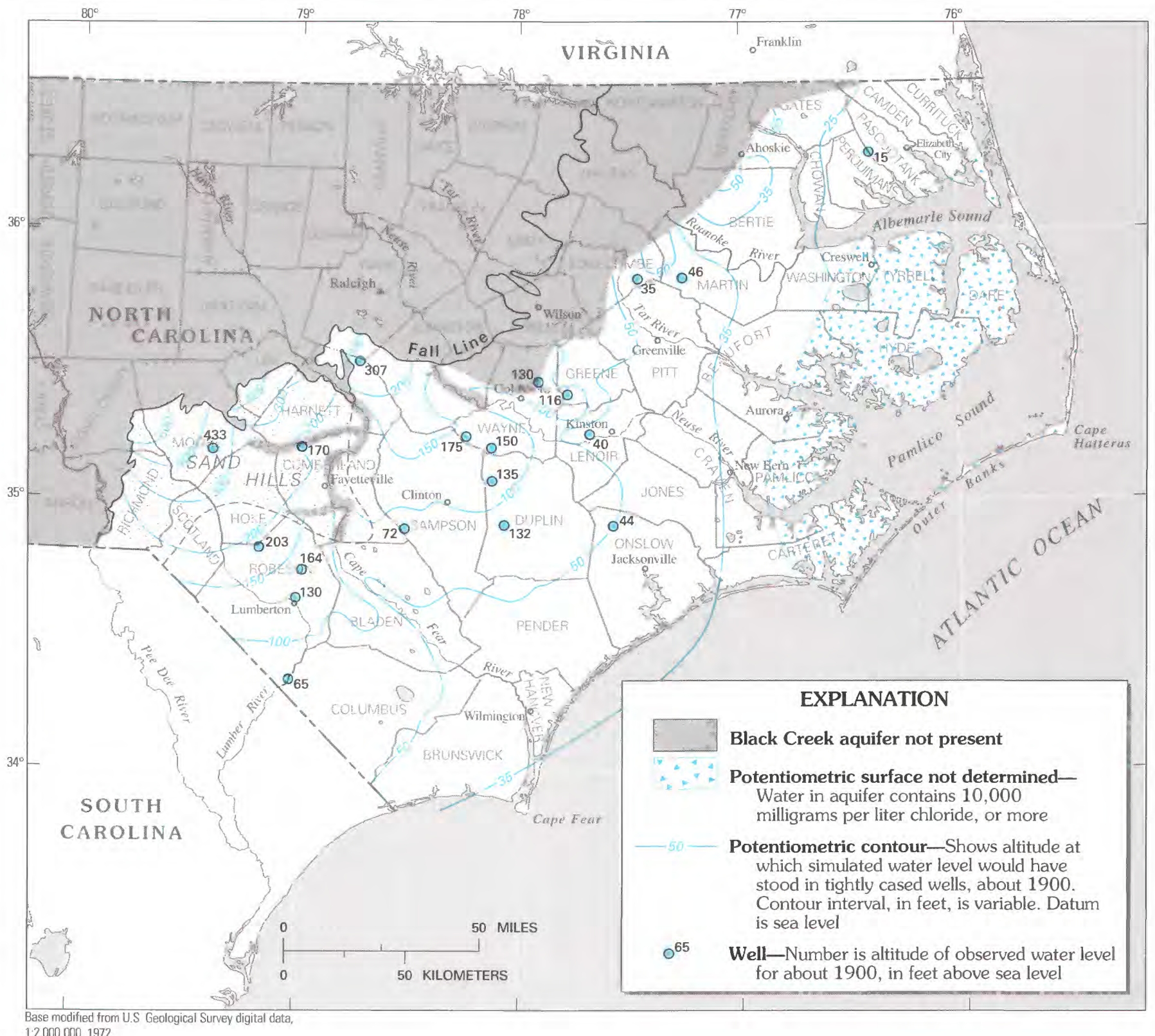

FIGURE 77.-Simulated prepumping (1900) potentiometric surface for the Black Creek aquifer (A4). 


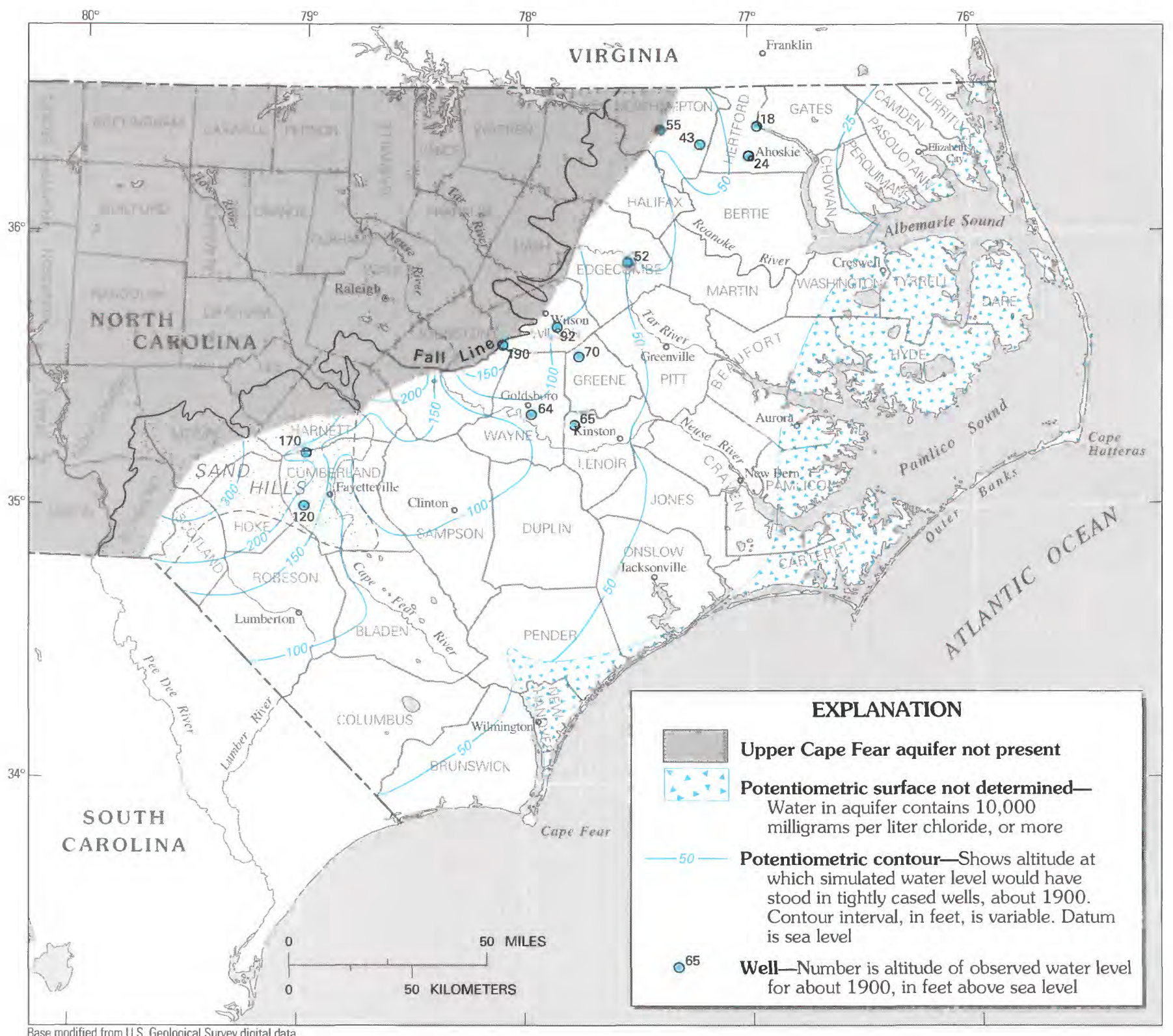

FIGURE 78. Simulated prepumping (1900) potentiometric surface for the upper Cape Fear aquifer (A3). 


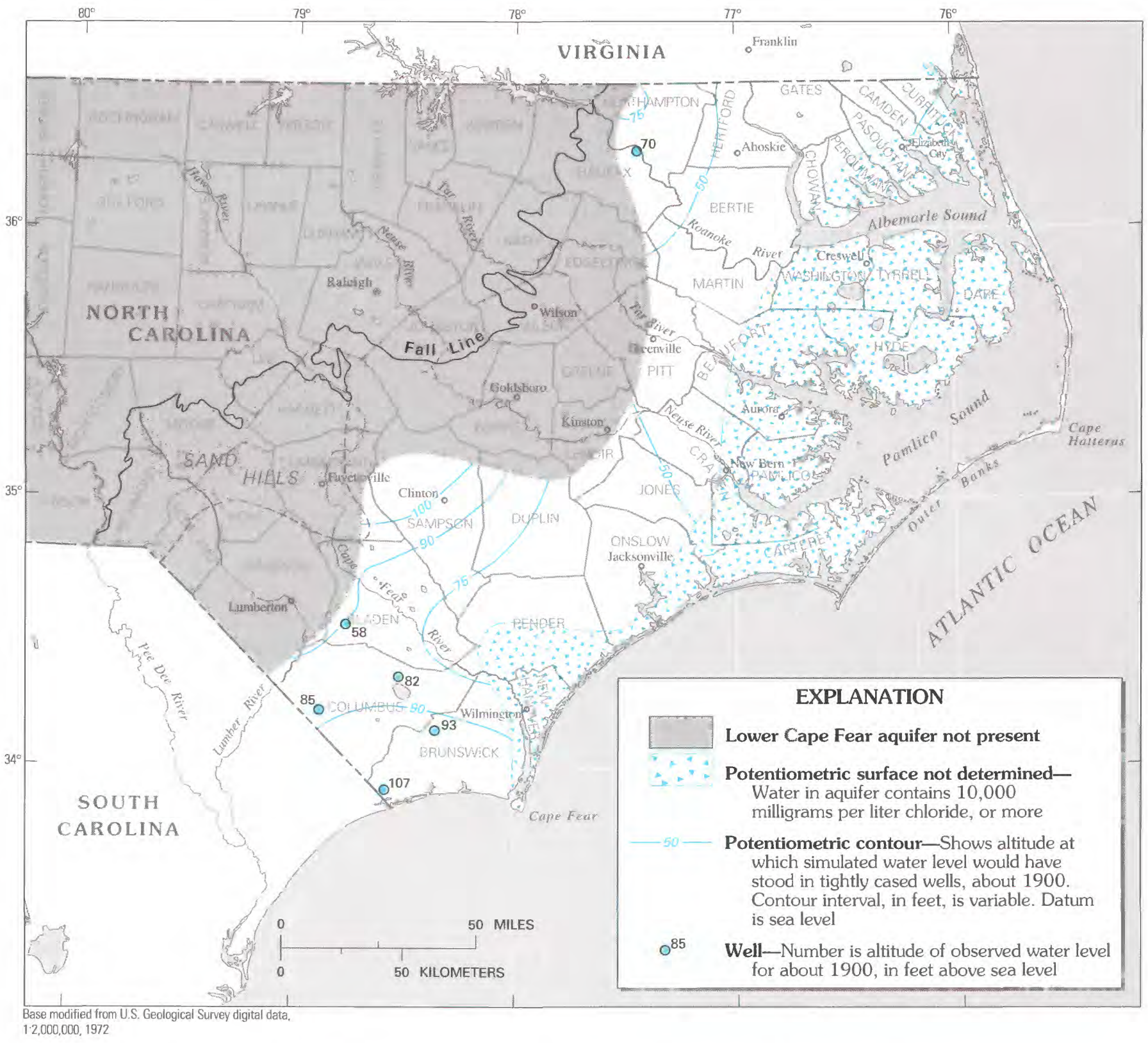

FIGURE 79.-Simulated prepumping (1900) potentiometric surface for the lower Cape Fear aquifer (A2). 


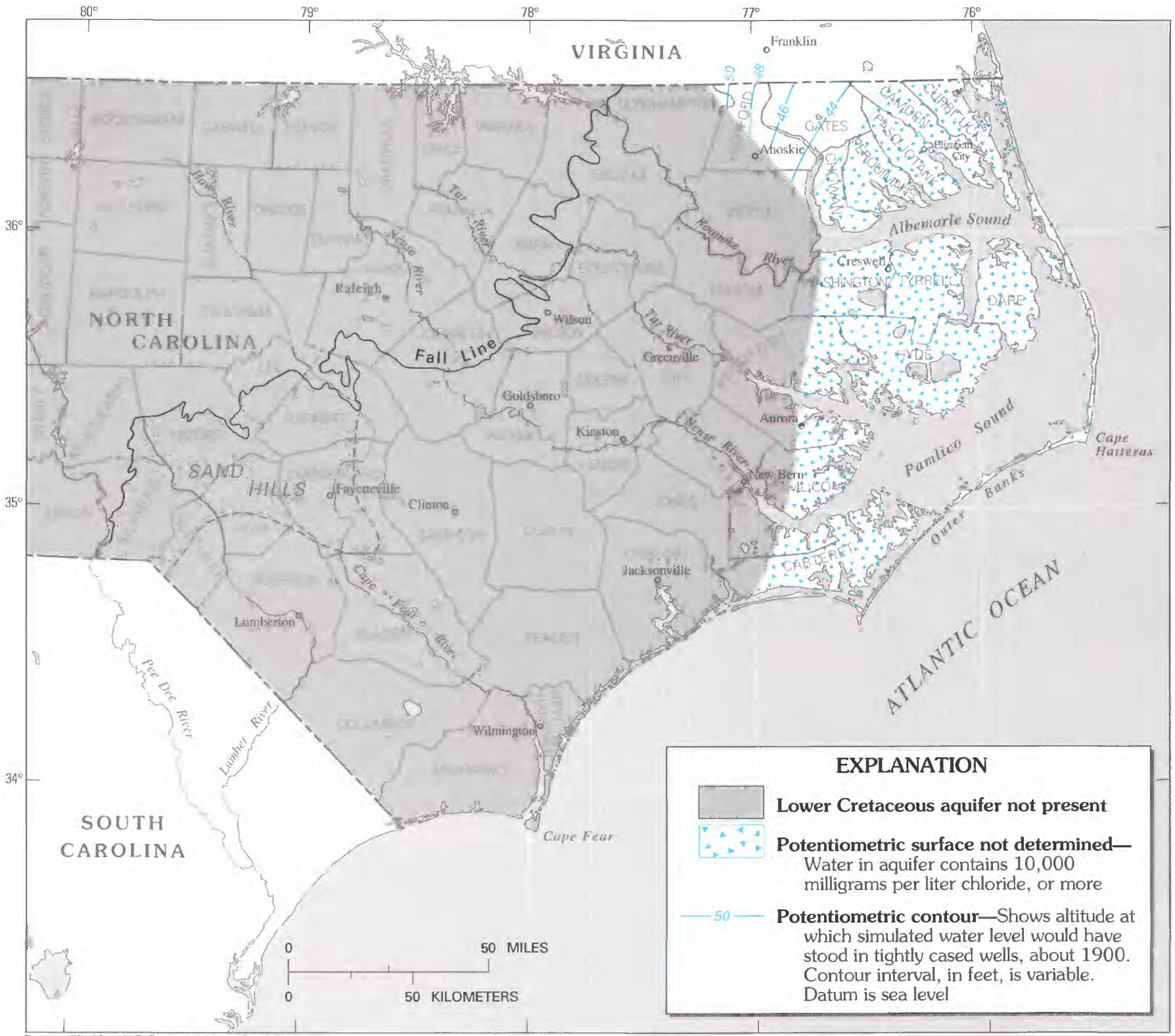

Base modified from U.S. Geological Survey digital data.

1:2,000,000, 1972

FIGURE 80.-Simulated prepumping (1900) potentiometric surface for the Lower Cretaceous aquifer (A1). 


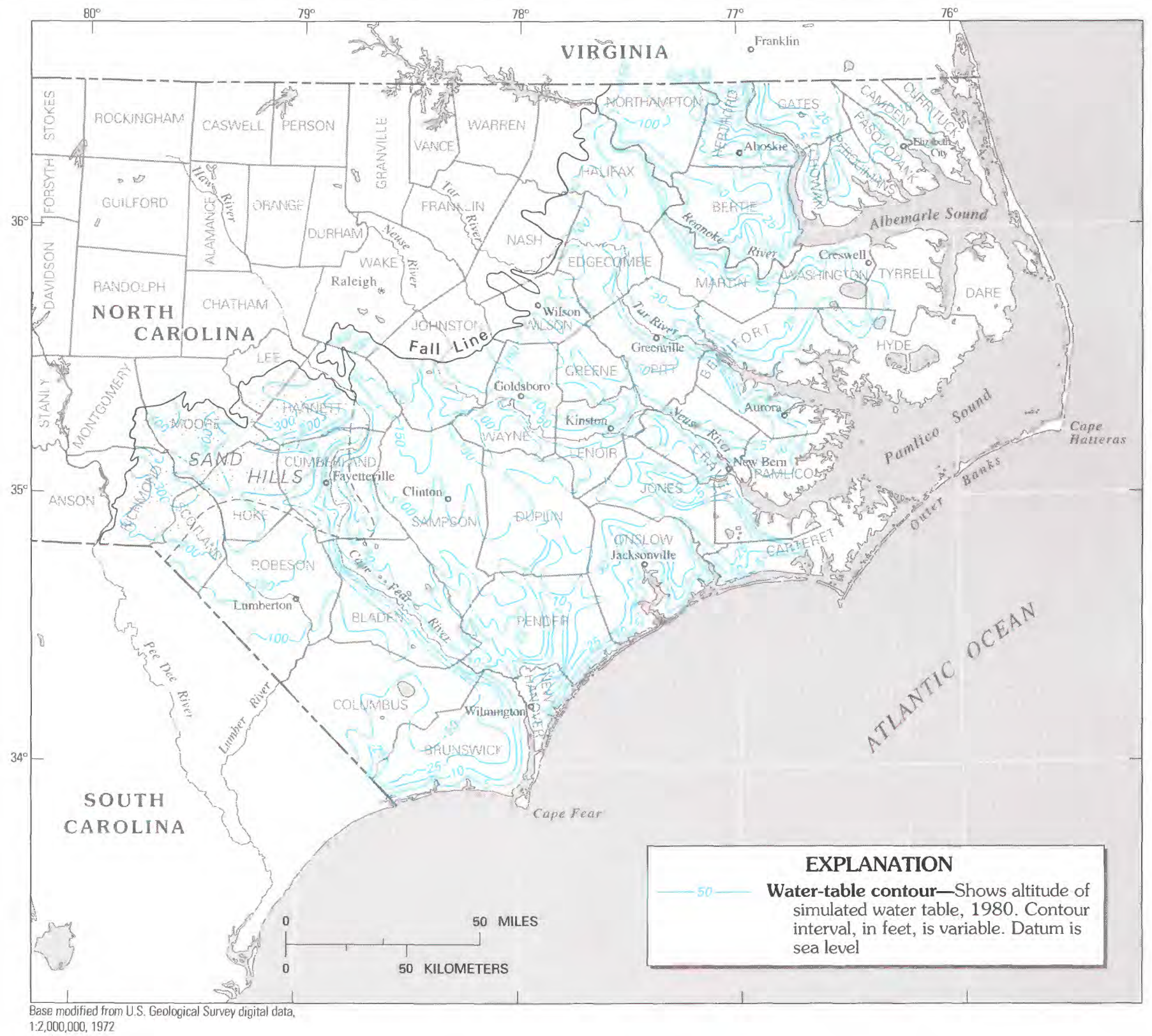

FIgURE 81.- Simulated 1980 water table for the surficial aquifer (A10). 


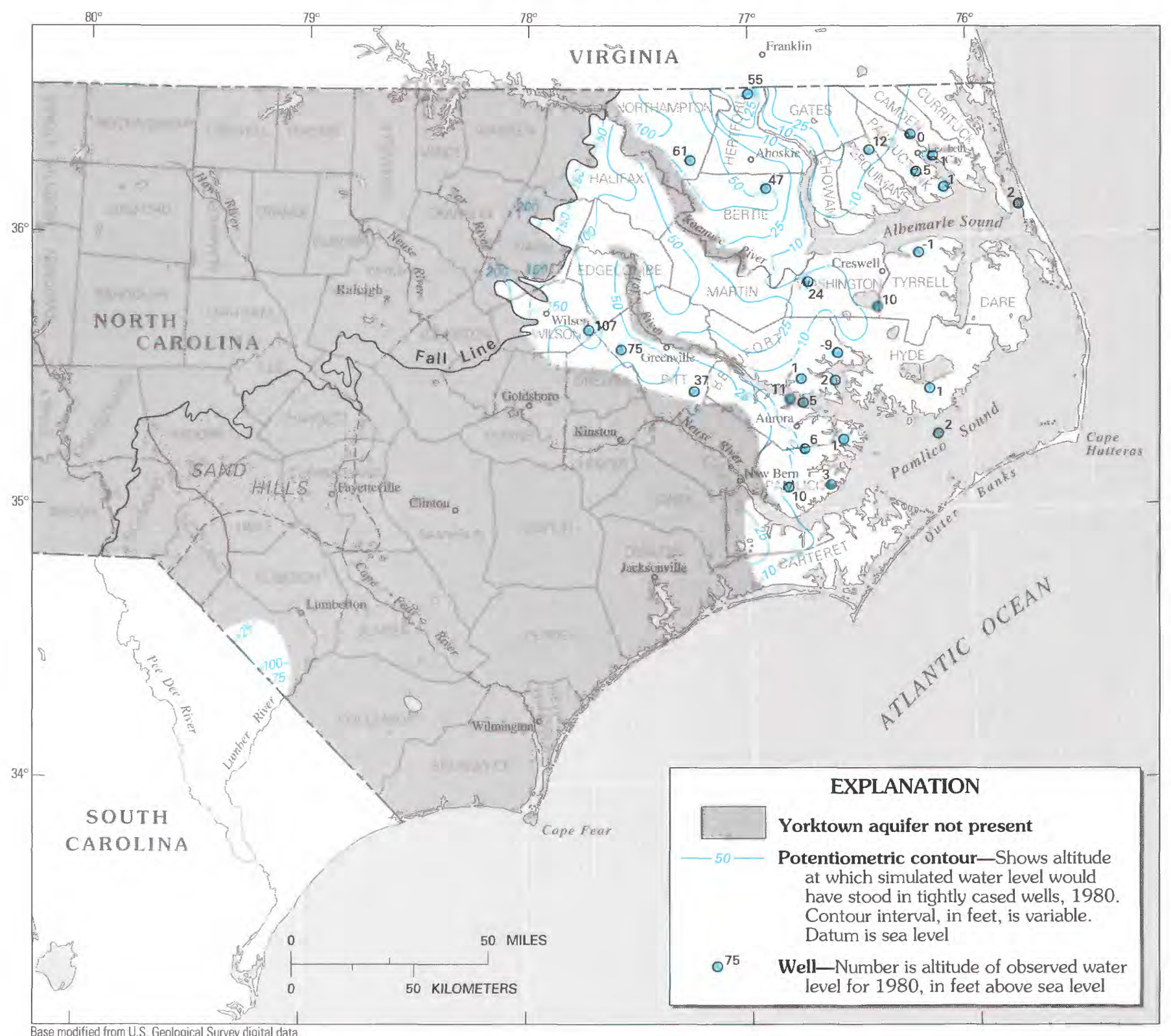
Base modified from U.S. Geological Survey digital data,
$1 \cdot 2,000,000.1972$

Figure 82.-Simulated 1980 potentiometric surface for the Yorktown aquifer (A9). 


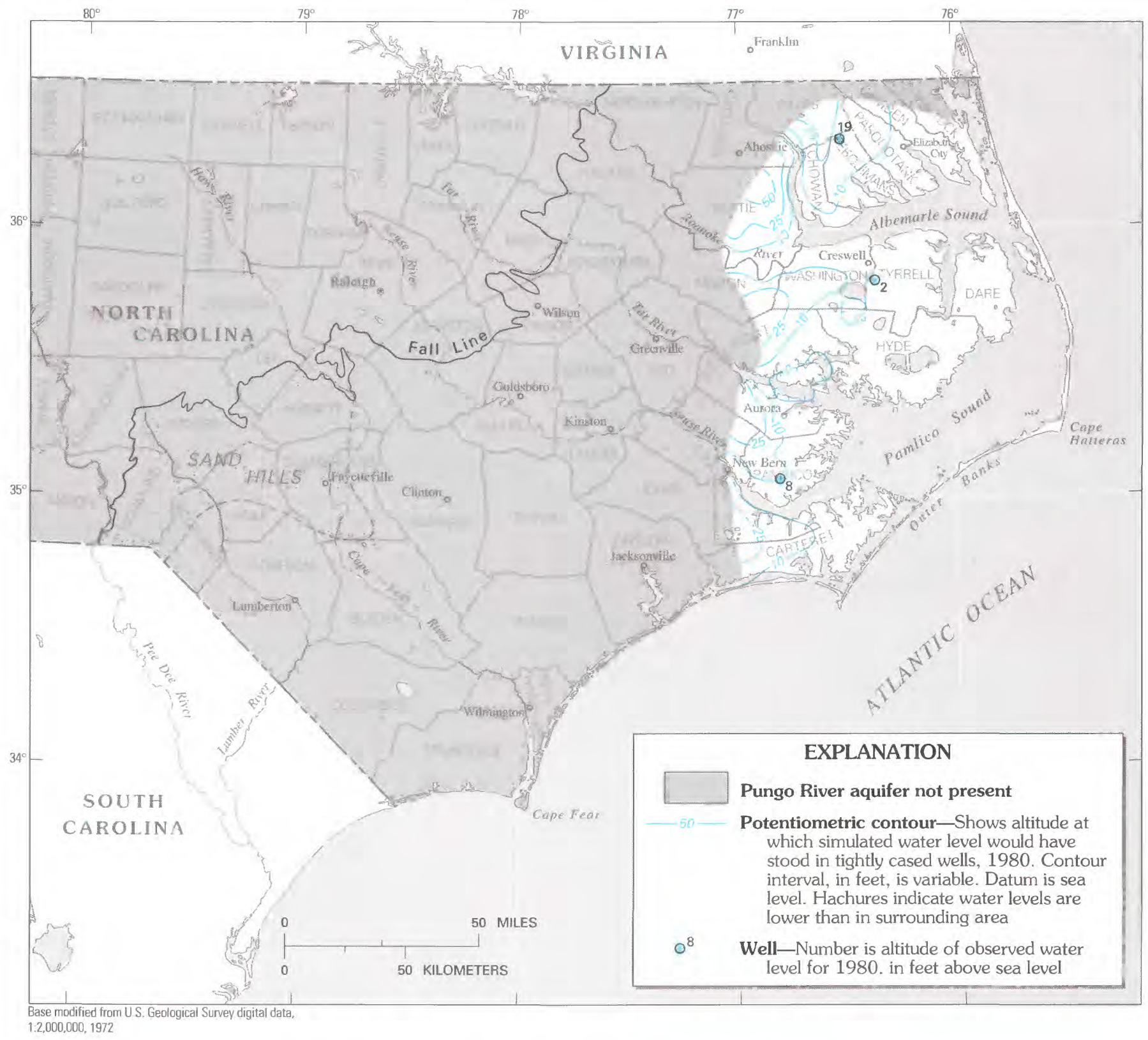

FIGURE 83.-Simulated 1980 potentiometric surface for the Pungo River aquifer (A8). 


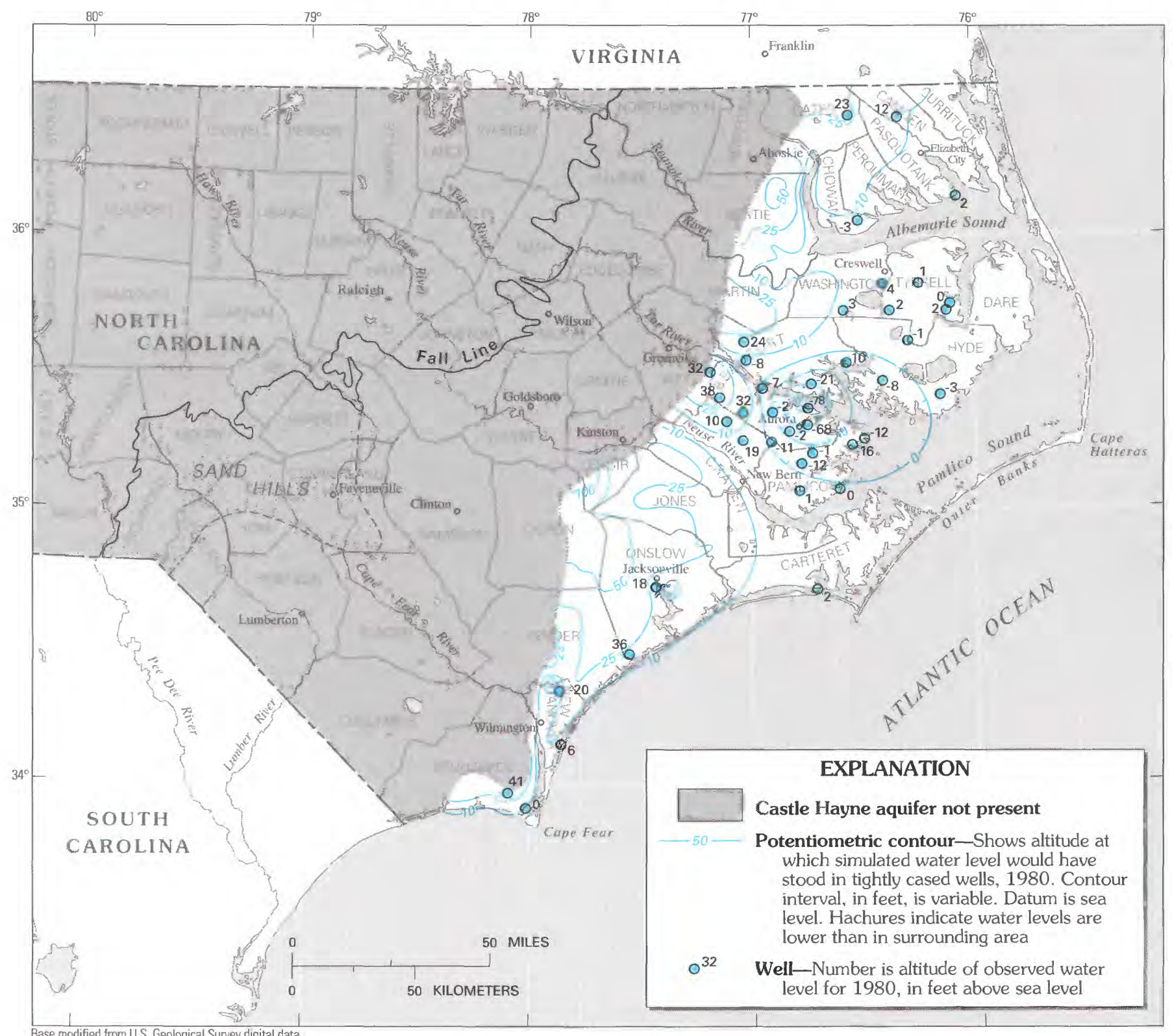

Base modified from U S. Geological Survey digital data,

1:2,000,000, 1972

FIGURE 84.-Simulated 1980 potentiometric surface for the Castle Hayne aquifer (A7). 


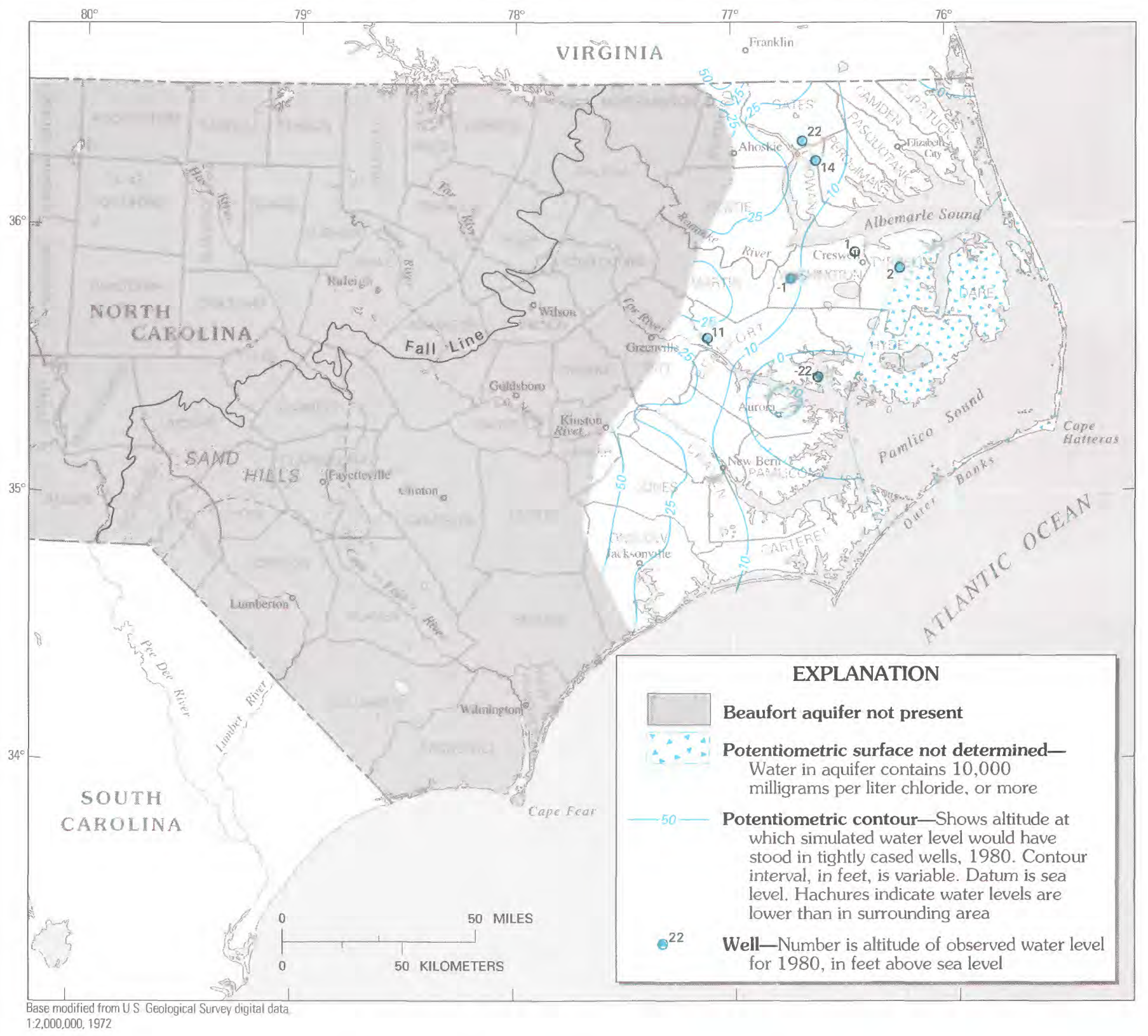

FIGURE 85.--Simulated 1980 potentiometric surface for the Beaufort aquifer (A6). 


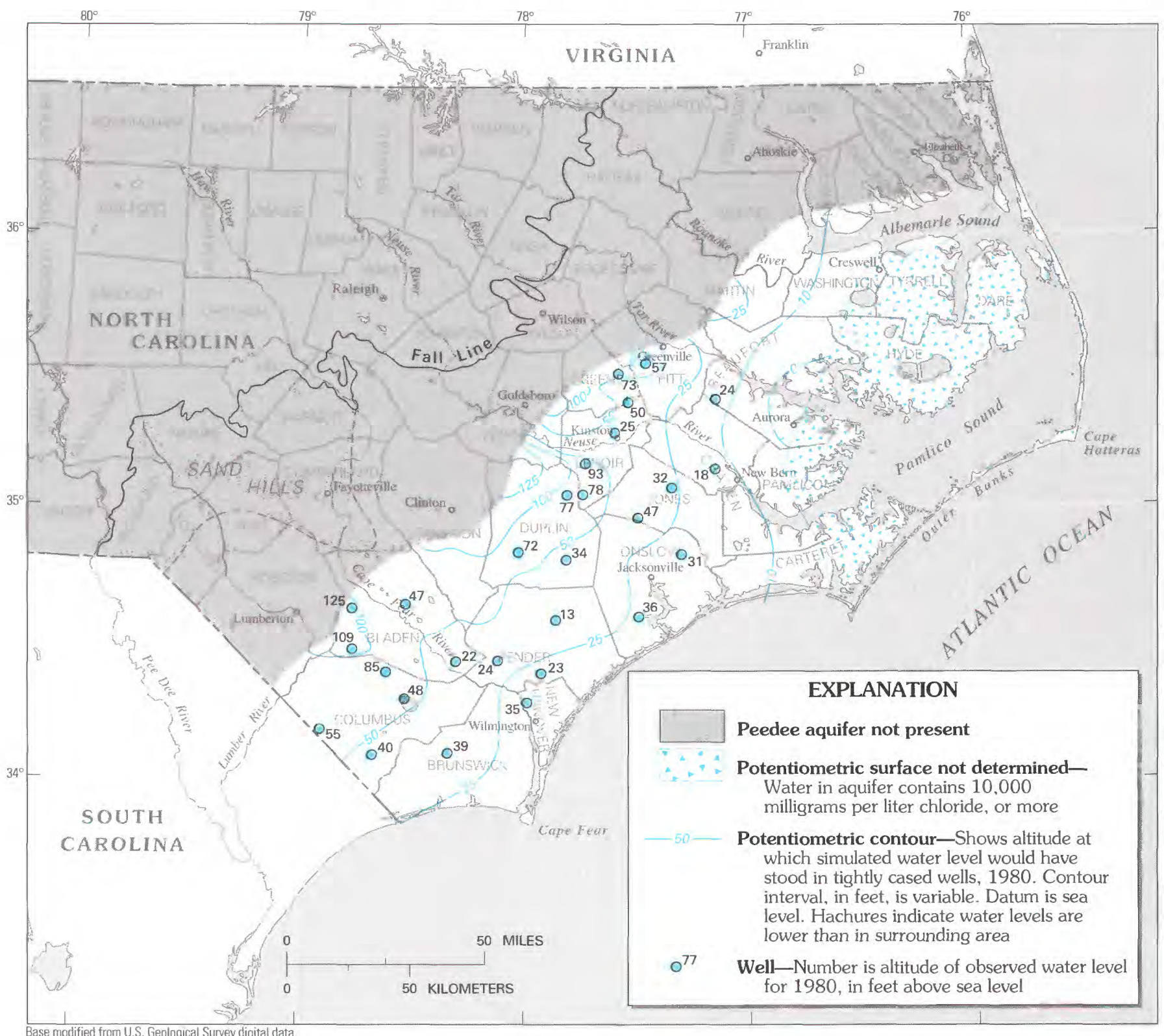

Base modified from U.S. Geological Survey digital data,

1:2,000,000, 1972

FIGURE 86.-Simulated 1980 potentiometric surface for the Peedee aquifer (A5). 


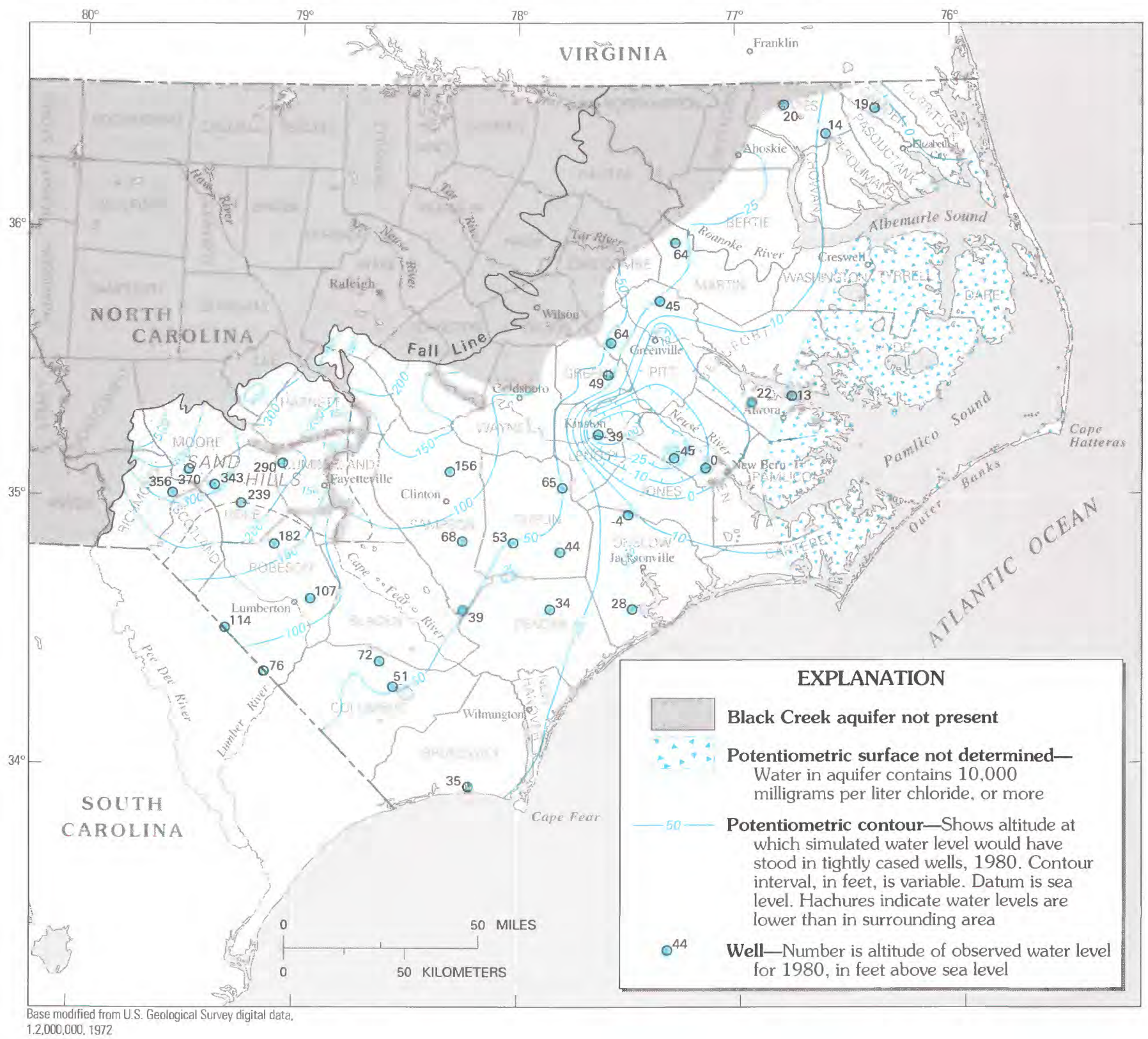

Figure 87.-Simulated 1980 potentiometric surface for the Black Creek aquifer (A4). 


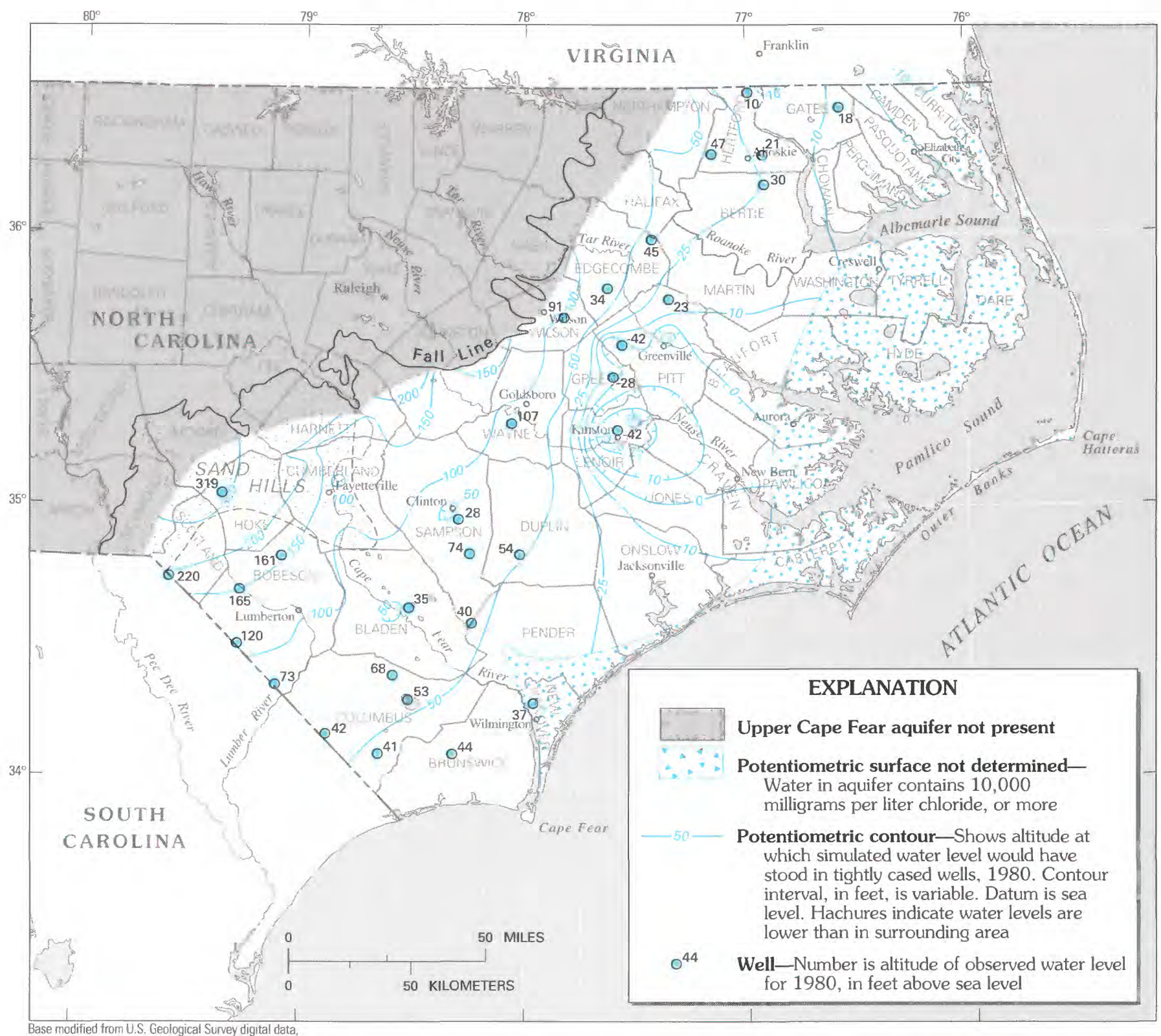
Base modified from U.S. Geological Survey digital data,
$1.2,000,000,1972$

Figure 88.- Simulated 1980 potentiometric surface for the upper Cape Fear aquifer(A3). 


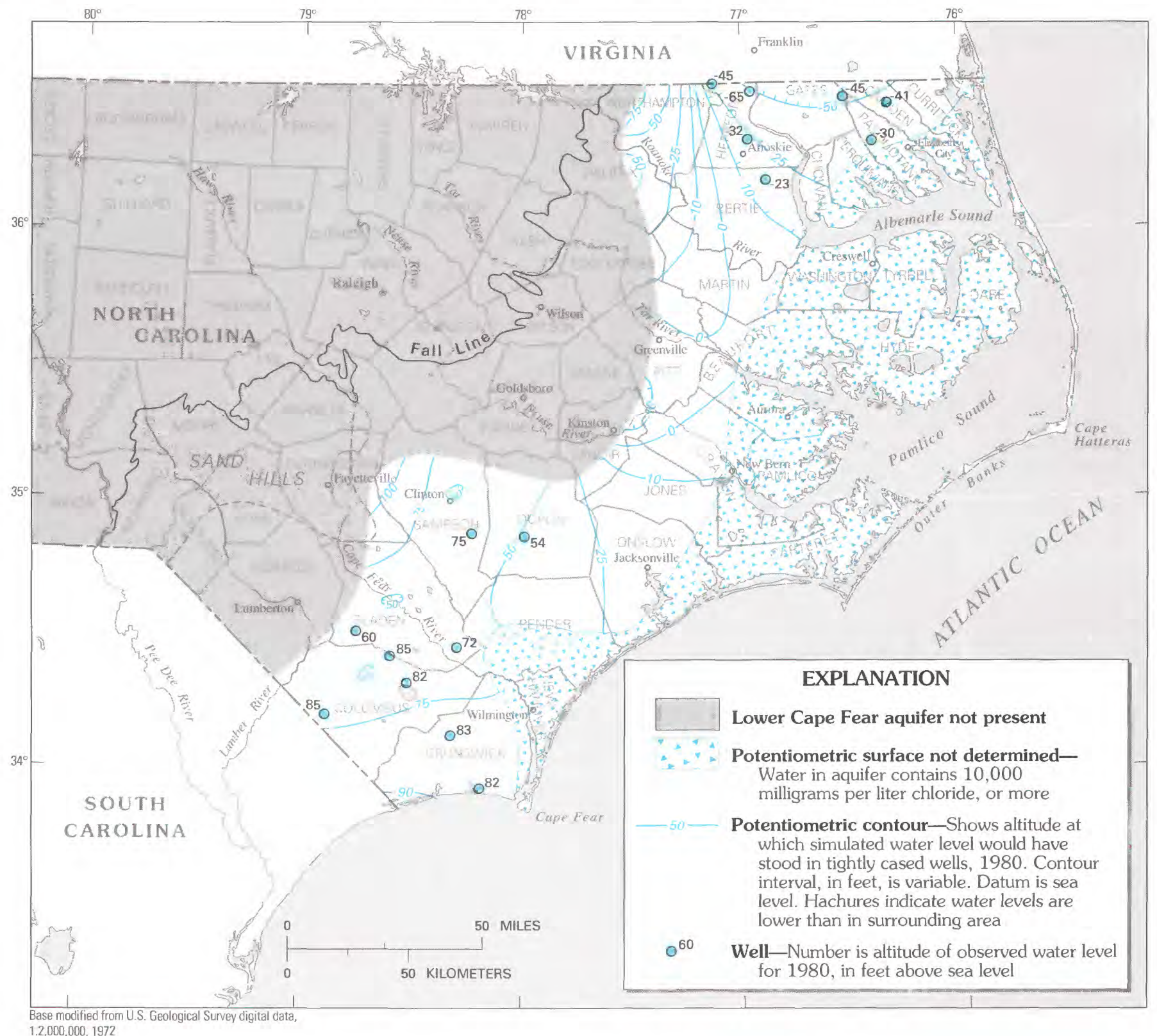

FIGURE 89.-Simulated 1980 potentiometric surface for the lower Cape Fear aquifer (A2). 


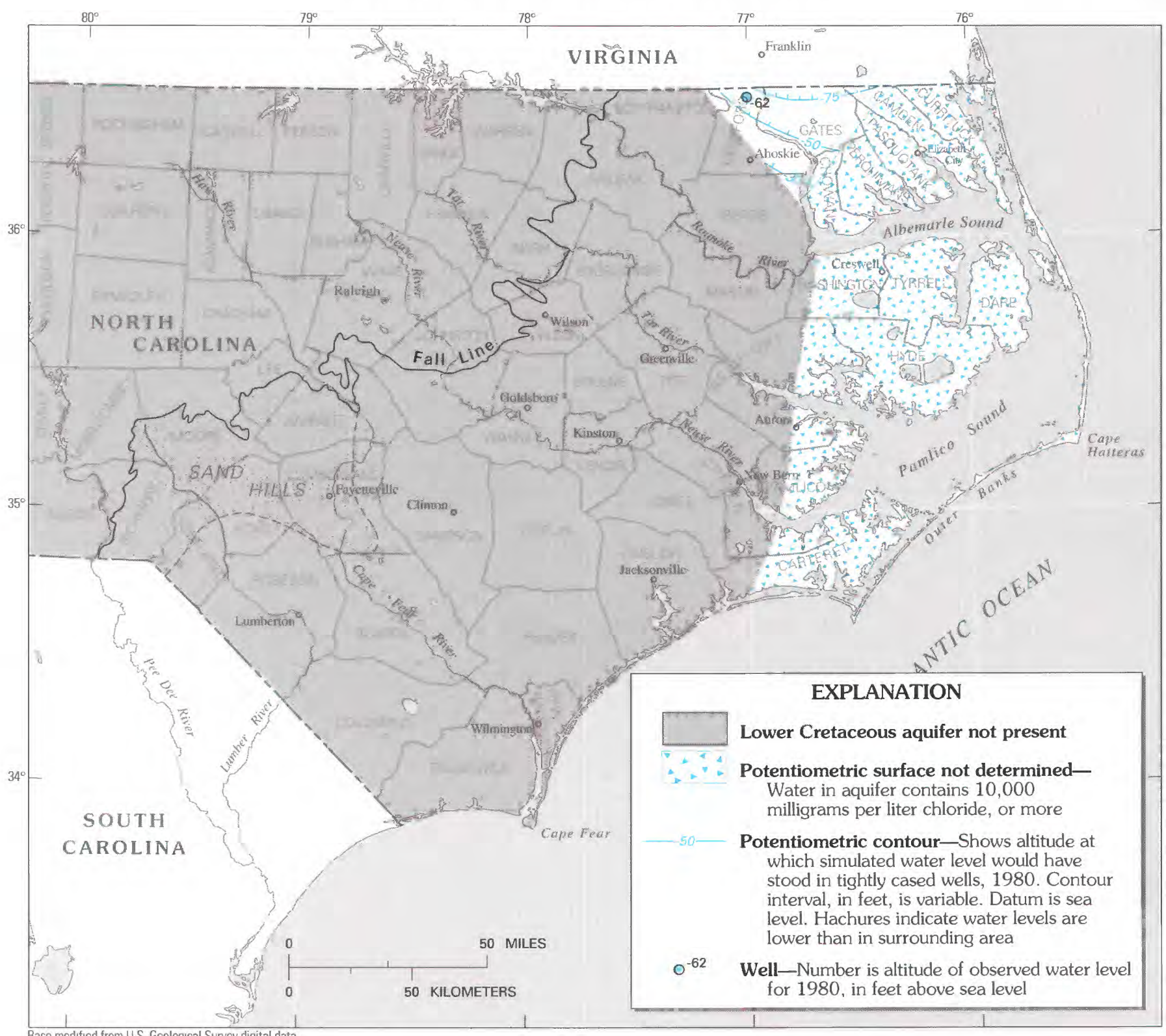

Base modified from U.S Geological Survey digital data,

$1 \cdot 2,000,000,1972$

FIGURE 90.-Simulated 1980 potentiometric surface for the Lower Cretaceous aquifer (A1). 
Although the calibrated flow model is not detailed enough for many management purposes, simulated potentiometric surfaces were generated (figs. 91-100) for the year 2000 (by assuming a uniform 3-percent annual increase in pumpage for 1980-2000 at the 1980 pumpage sites) to assess the effect of future pumping on potentiometric surfaces. Actually, several major ground-water pumpages are not expected to increase at this rate during this period, notably at Franklin, Va., and at the phosphate-mining operations in Beaufort County, N.C. Thus, in these areas, the year 2000 simulations may not accurately reflect what is likely to occur.

Considerable areas of most aquifers exhibit drawdowns of less than $10 \mathrm{ft}$ for the 1900-80 and 1980-2000 periods. Comparison of the water-table maps of 1900 , 1980 , and 2000 (figs. 71, 81, and 91) shows little or no change in water levels in the surficial aquifer (A10). The same is true for the potentiometric surfaces of the Yorktown aquifer (A9), as seen in figures 72,82 , and 92. Except for the immediate vicinity of major withdrawals, potentiometric surfaces in the updip (western) parts of the Castle Hayne (A7), Beaufort (A6), Peedee (A5), Black Creek (A4), and upper Cape Fear (A3) aquifers declined $10 \mathrm{ft}$ or less. The areas of little change for these confined aquifers are where each one is directly overlain by either the surficial aquifer (A10) or the Yorktown aquifer (A9). (Compare figs. 73-78, figs. 83-88, and figs. 93-98.)

By 1980, water levels in confined aquifers in the North Carolina Coastal Plain had not declined below the tops of the aquifers. When and if this happens, the aquifers will change from confined to unconfined conditions, and the aquifer storage coefficients will increase by several orders of magnitude (from about $10^{-4}$ to about $\left.1 \times 10^{-1}\right)$. Subsequent drawdowns will occur by dewatering rather than by expansion of the water and compaction of aquifer and confining-unit sediments. Drawdowns will then proceed at a slower rate than under the previous confined conditions. Thus, model predictions of year 2000 water levels for such situations might tend to overestimate drawdowns regionally; however, locally they may underestimate drawdowns near the pumping centers.

\section{VERTICAL FLOW}

As a generalization, the downward vertical movement of ground-water recharge to confined aquifers under natural conditions occurs mainly in interstream areas, and ground-water discharge upward from the confined aquifer system occurs mainly in stream valleys and in downdip (coastward) areas. This general pattern of recharge and discharge has been significantly altered in several areas of the North Carolina Coastal Plain, where pumping from several of the aquifers has reduced the hydraulic head in these aquifers over large areas and has thus disturbed the prepumping head relations that existed between the aquifers. When those head relations are changed, the potential for water to move from one aquifer to another through the intervening confining unit(s) is changed and often reversed. The changes in flow direction due to pumping are evident from a comparison of prepumping conditions of 1900 in figures 101 through 109 with those of 1980 in figures 110 through 118.

In the northeastern North Carolina Coastal Plain, during prepumping conditions, vertical ground-water flow through the Black Creek (CU4), upper Cape Fear (CU3), lower Cape Fear (CU2), and Lower Cretaceous (CU1) confining units (figs. 106-109) was upward in many parts of the area. By 1980 , vertical flow gradients had been reversed across large parts of these confining units (figs. 115-118). Vertical flow by 1980 was downward in response to large pumpages from the Lower Cretaceous (A1) and lower Cape Fear (A2) aquifers in Franklin, Va.

Extensive pumping from the Black Creek (A4) and upper Cape Fear (A3) aquifers in the central North Carolina Coastal Plain area has resulted in reversal of flow from upward to downward through the Peedee (CU5), Black Creek (CU4), and upper Cape Fear (CU3) confining units (figs. 105-107 and 114-116). However, flow through the upper Cape Fear confining unit in the area between Kinston and New Bern is still upward in response to pumping from the overlying Black Creek aquifer (A4), which is pumped more heavily than the upper Cape Fear aquifer (A3). A large area of the Black Creek confining unit (CU4) in the southern North Carolina Coastal Plain has experienced a change in vertical flow from upward to downward in response to moderate but widespread pumping (figs. 106 and 115).

In the Beaufort County area, vertical flow under prepumping conditions was generally upward, this being a discharge area for most of the North Carolina Coastal Plain aquifers present there. After large-scale pumping began in 1965 in the Castle Hayne aquifer (A7), vertical flow was toward the Castle Hayne aquifer; that is, upward vertical flow across confining units CU6 and CU5 was greater than before, and vertical flow through the Yorktown (CU9) through Castle Hayne (CU7) confining units reversed direction from upward to downward in the vicinity of the large-scale pumping areas.

Text continues on p. M139. 


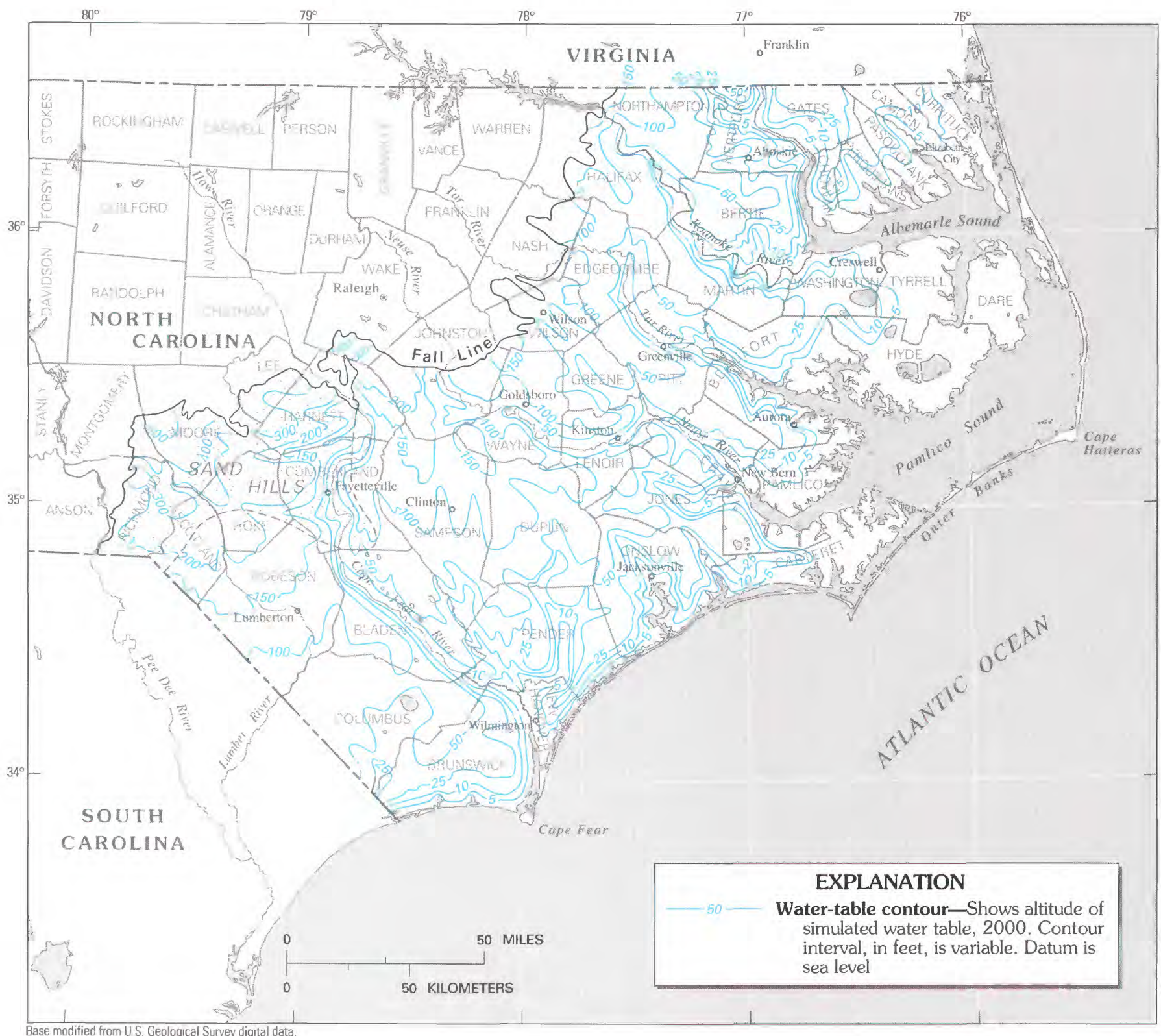
1.2,000,000, 1972

FIGURE 91.-Simulated year 2000 water table for the surficial aquifer (A10), assuming 3-percent annual increase in pumpage during $1980-2000$. 


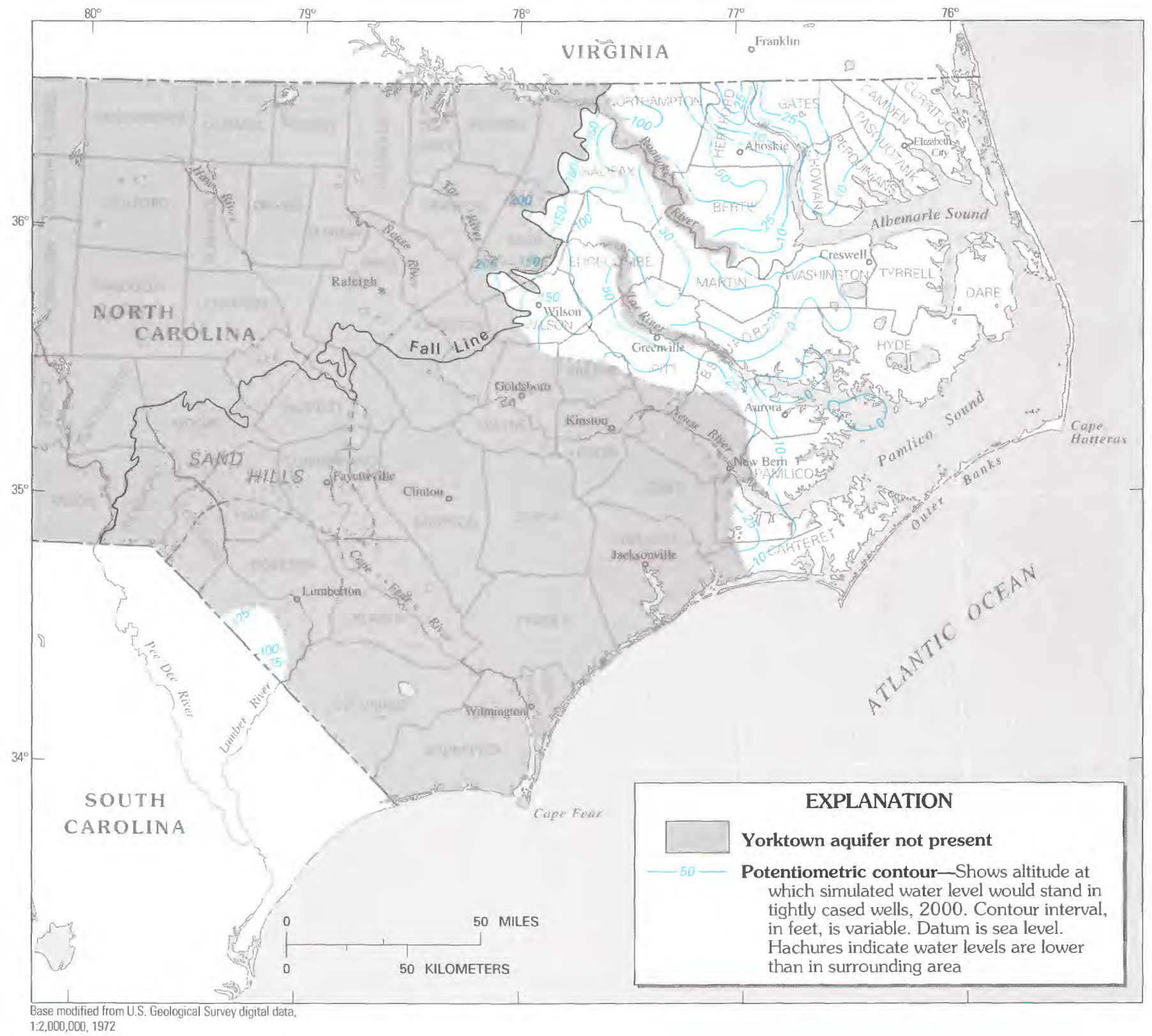

Figure 92.-Simulated year 2000 potentiometric surface for the Yorktown aquifer (A9), assuming 3-percent annual increase in pumpage during 1980-2000. 


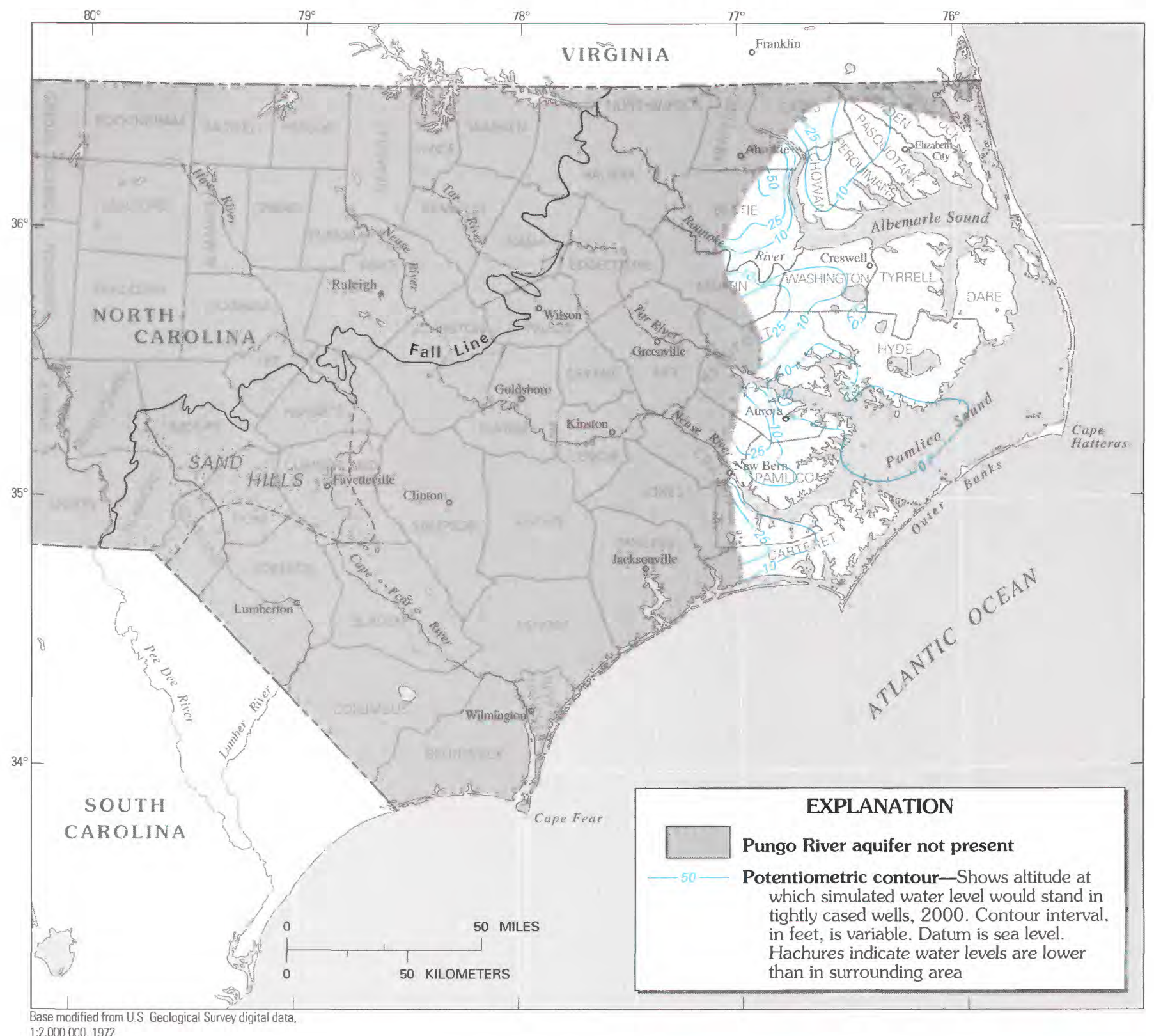

Figure 93.-Simulated year 2000 potentiometric surface for the Pungo River aquifer (A8), assuming 3-percent annual increase in pumpage during 1980-2000. 


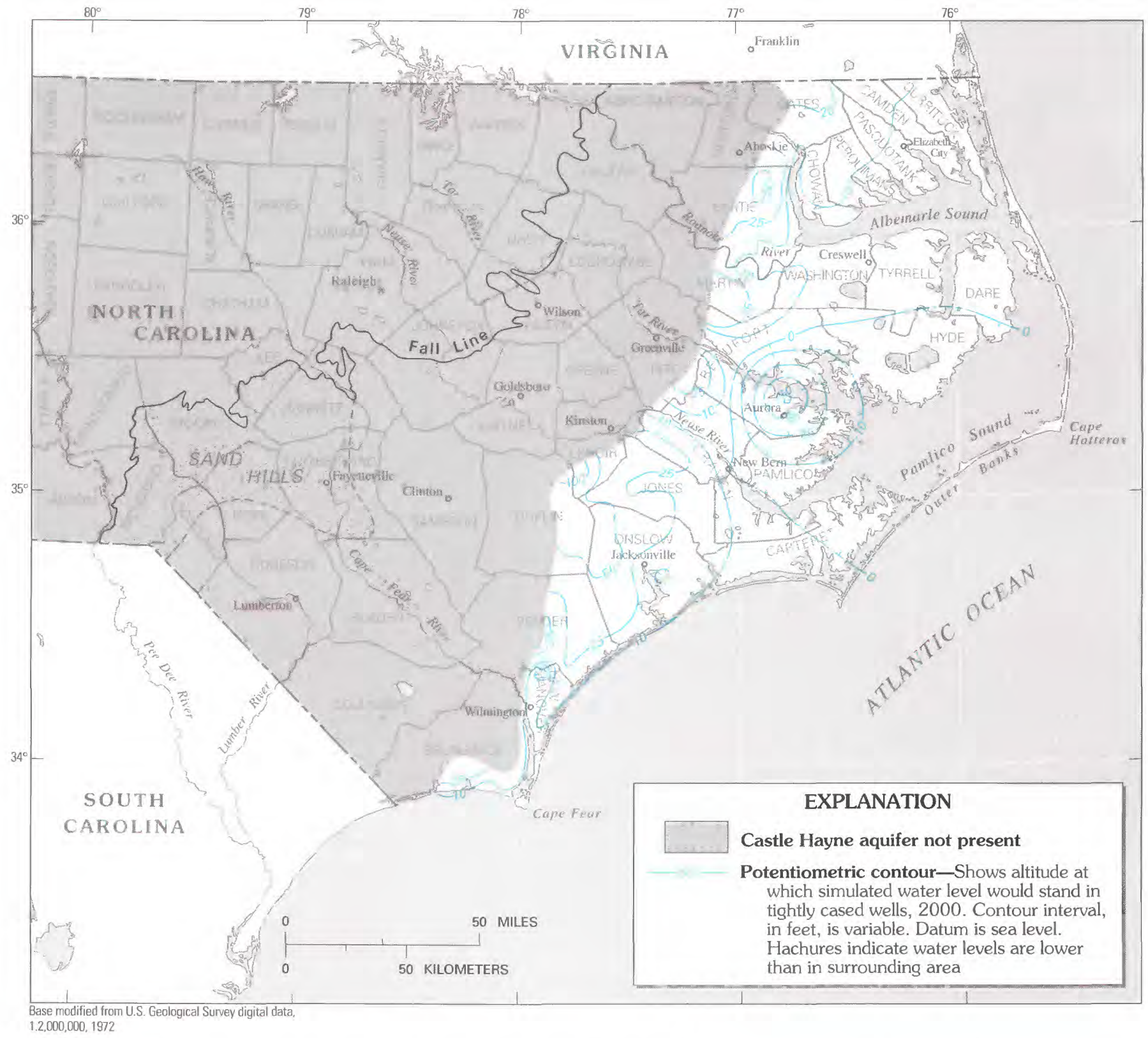

Figure 94.- Simulated year 2000 potentiometric surface for the Castle Hayne aquifer (A7), assuming 3-percent annual increase in pumpage during 1980-2000. 


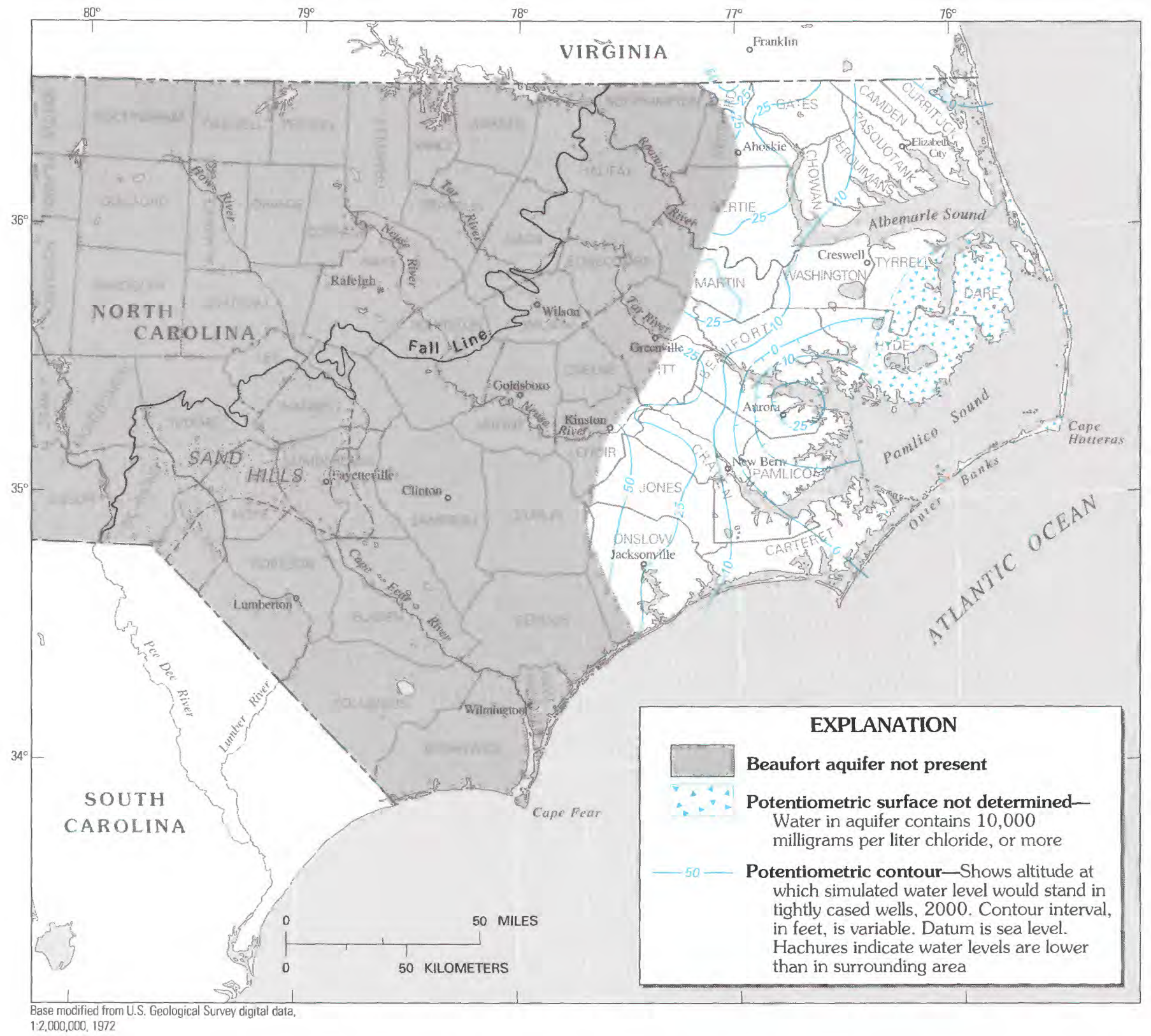

Figure 95.-Simulated year 2000 potentiometric surface for the Beaufort aquifer (A6), assuming 3-percent annual increase in pumpage during 1980-2000. 


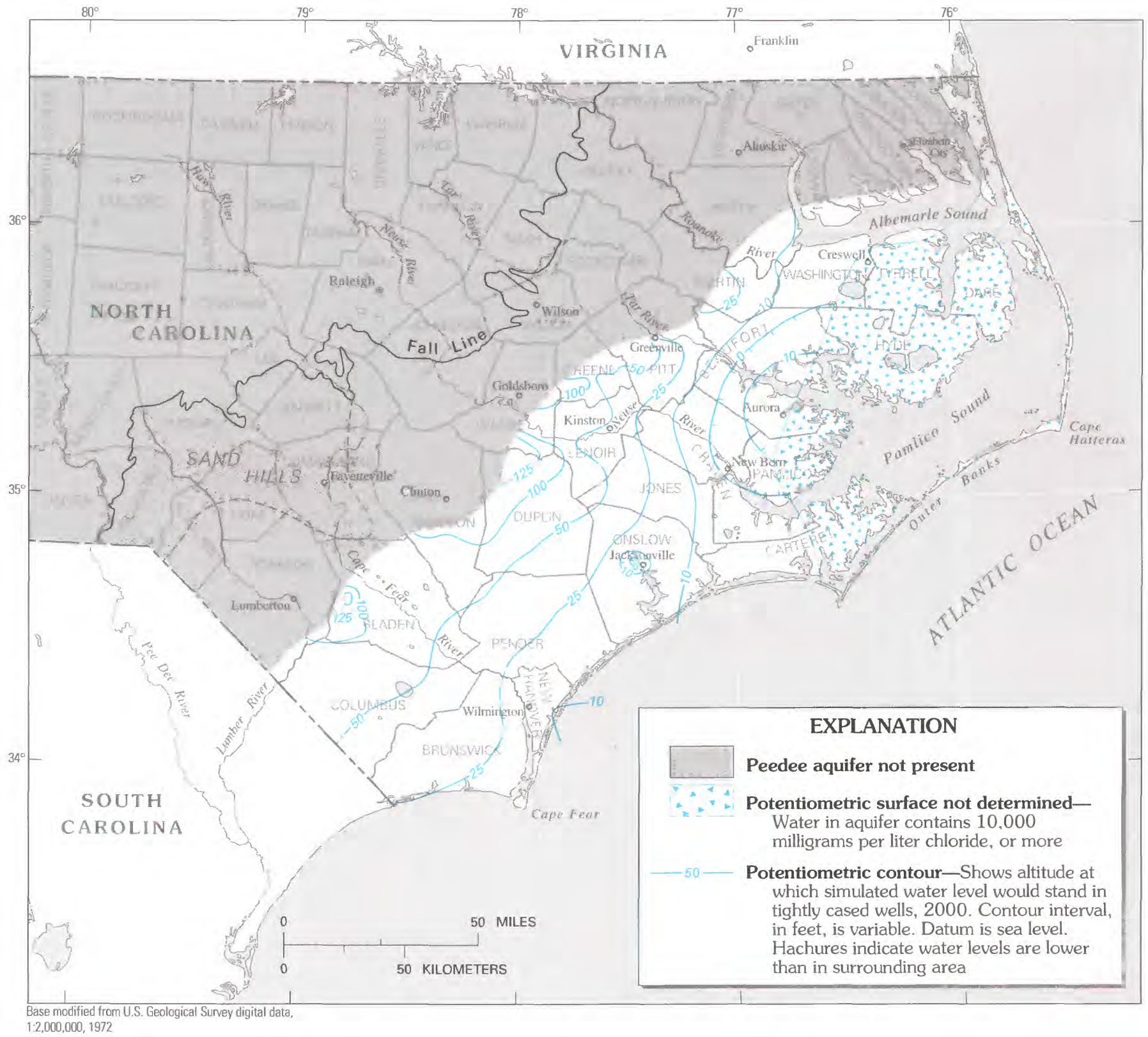

FiguRE 96.--Simulated year 2000 potentiometric surface for the Peedee aquifer (A5), assuming 3-percent annual increase in pumpage during 1980-2000. 


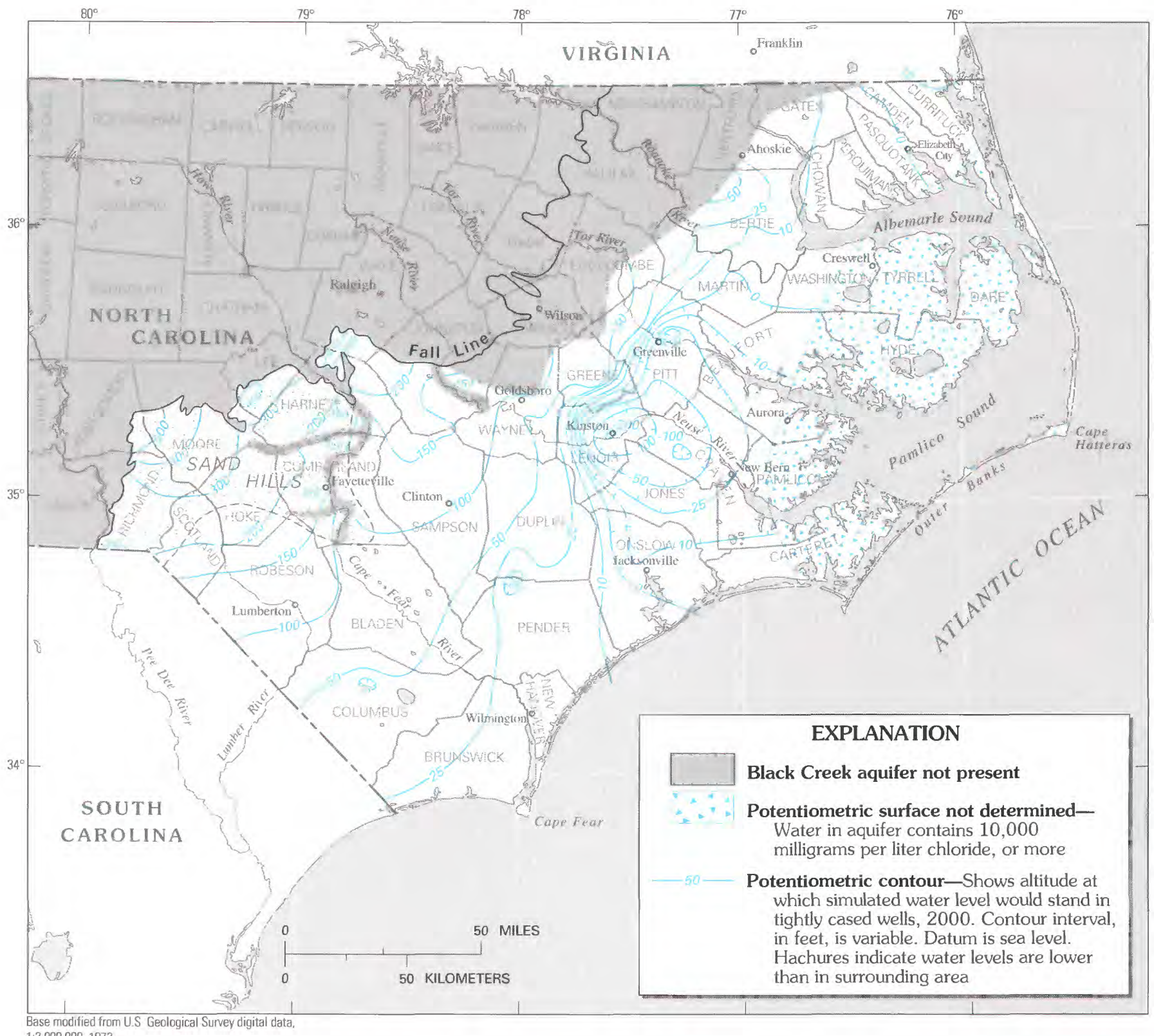

S Geological Survey digital data,

FIGURE 97.-Simulated year 2000 potentiometric surface for the Black Creek aquifer (A4), assuming 3-percent annual increase in pumpage during 1980-2000. 


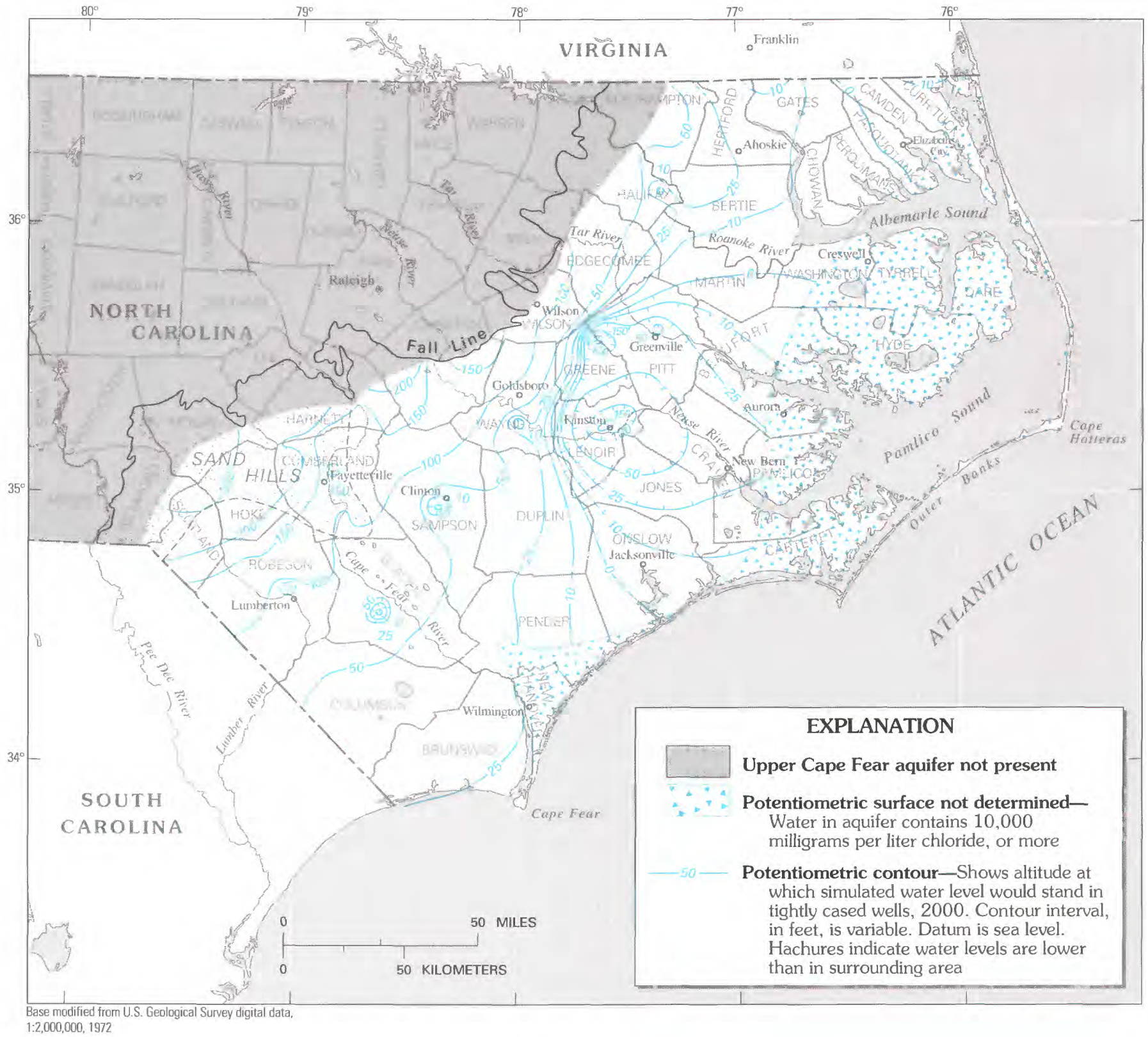

FIGURE 98.-Simulated year 2000 potentiometric surface for the upper Cape Fear aquifer (A3), assuming 3-percent annual increase in pumpage during 1980-2000. 


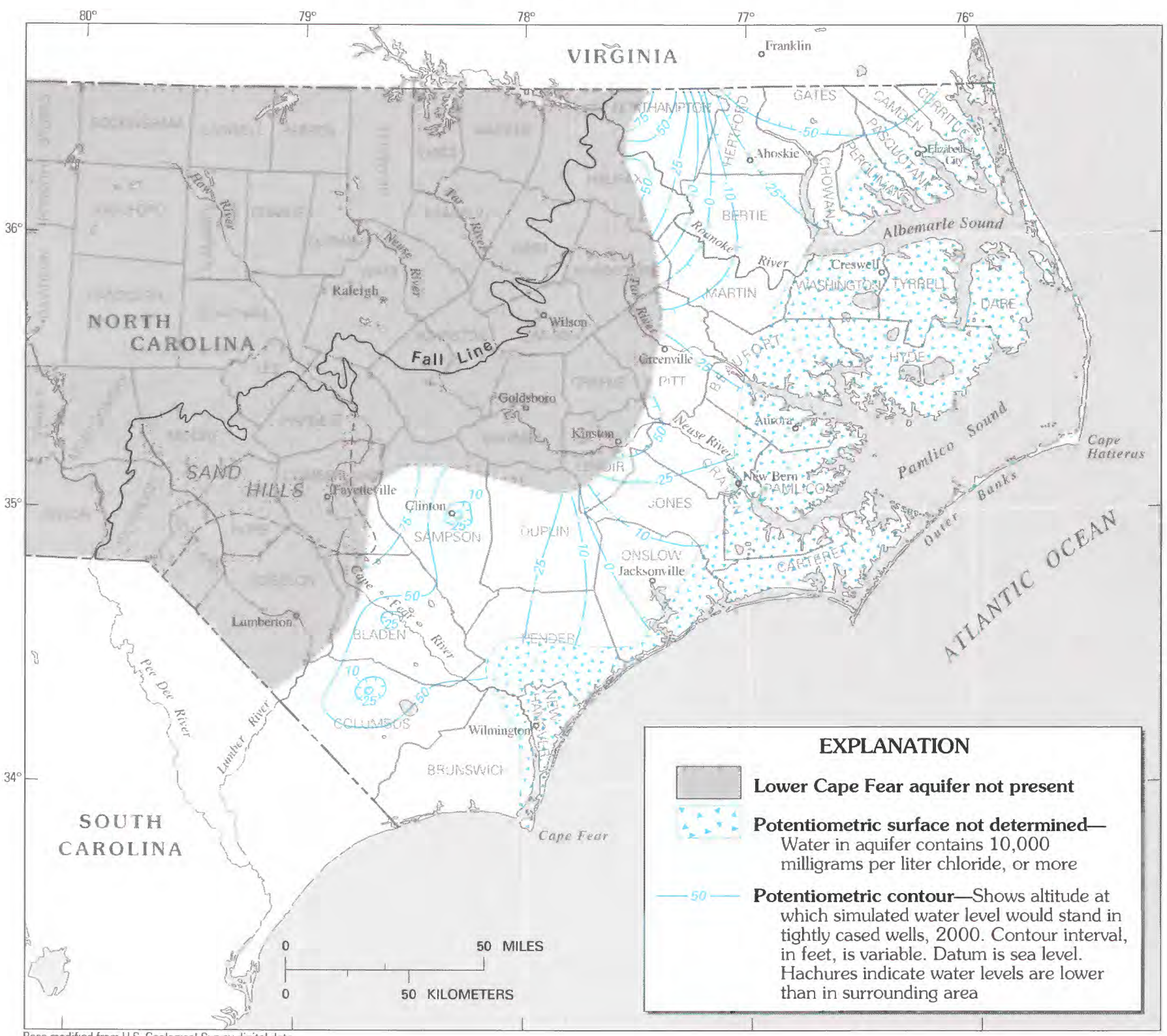
Base modified from U.S. Geological Survey digital data,
$1: 2,000,000,1972$

FIGURE 99.-Simulated year 2000 potentiometric surface for the lower Cape Fear aquifer (A2), assuming 3-percent annual increase in pumpage during 1980-2000. 


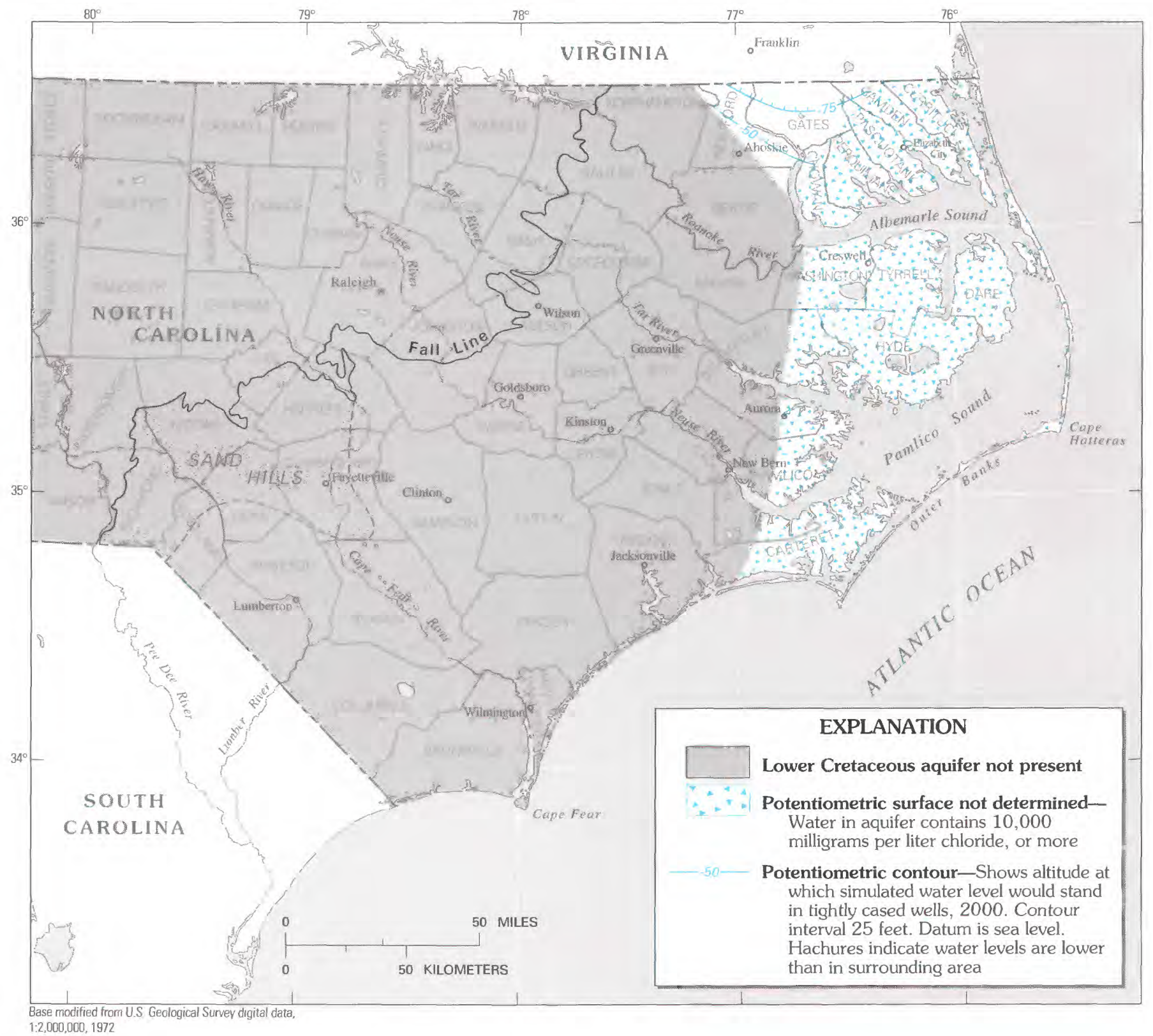

FIGURE 100.- Simulated year 2000 potentiometric surface for the Lower Cretaceous aquifer (A1), assuming 3-percent annual increase in pumpage during 1980-2000. 


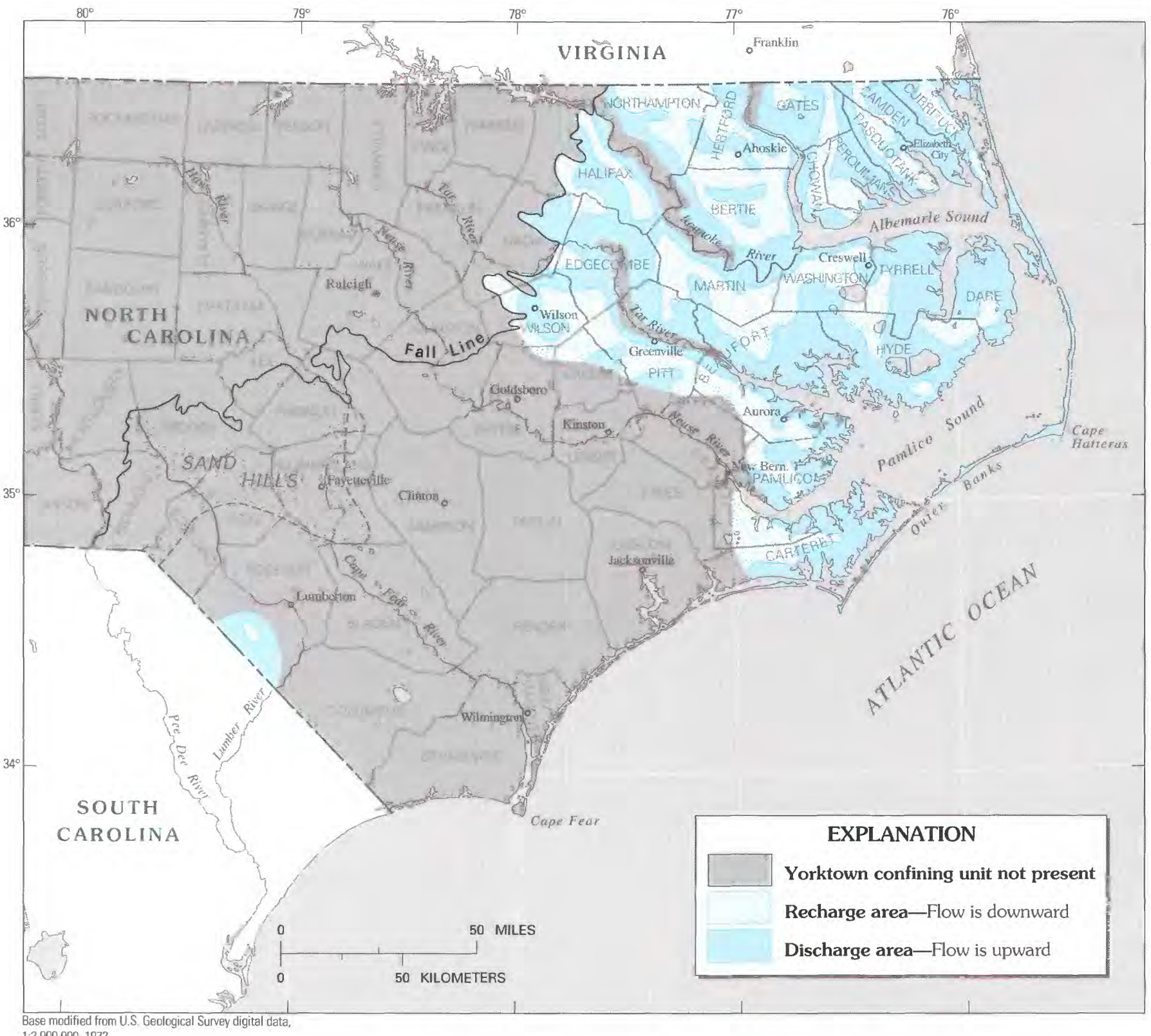

$1: 2000,000,1972$

FIGURE 101.-Net vertical flow of water through the Yorktown confining unit (CU9) simulated for predevelopment (1900) conditions. 


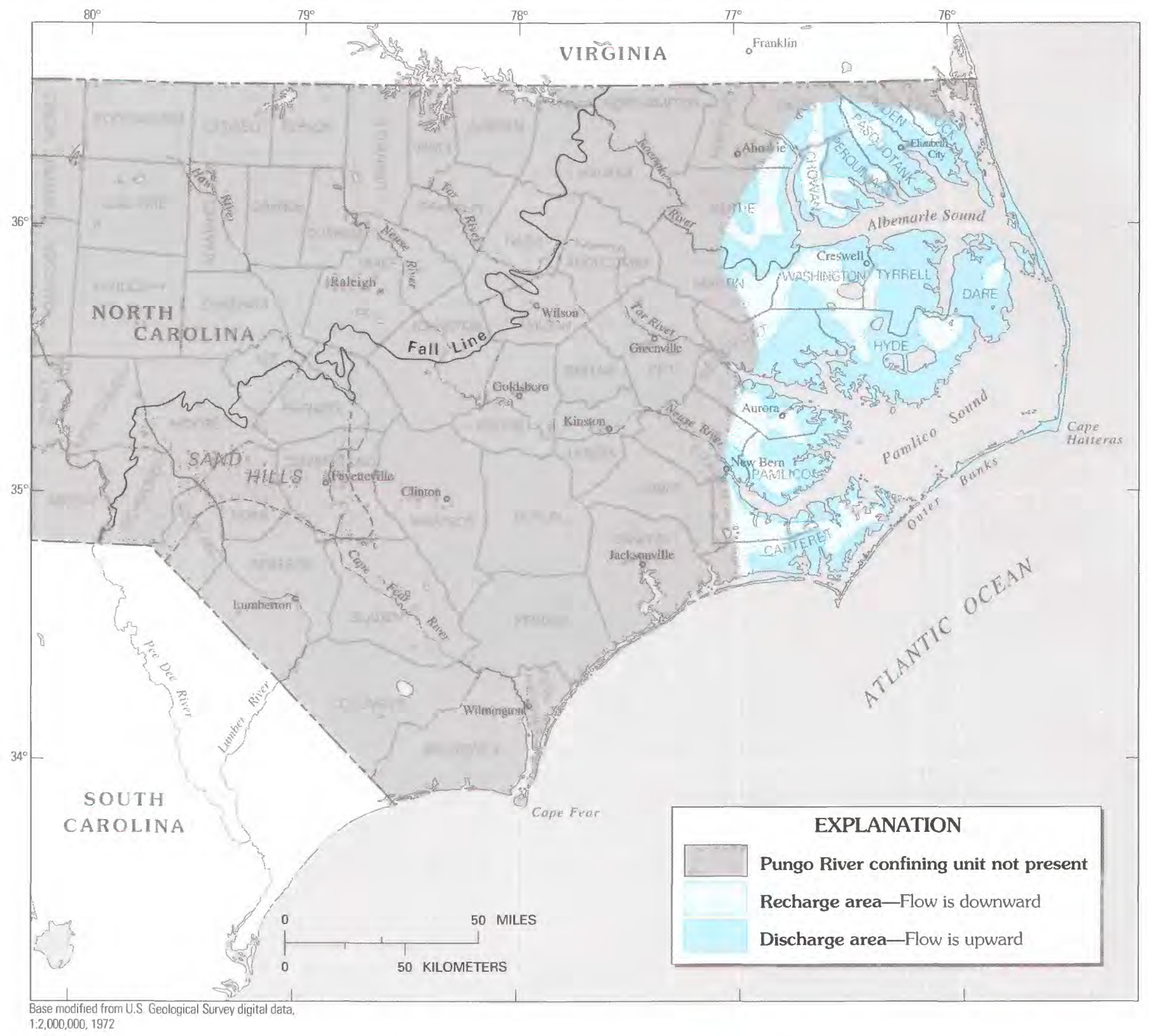

FIGURE 102.-Net vertical flow of water through the Pungo River confining unit (CU8) simulated for predevelopment (1900) conditions. 


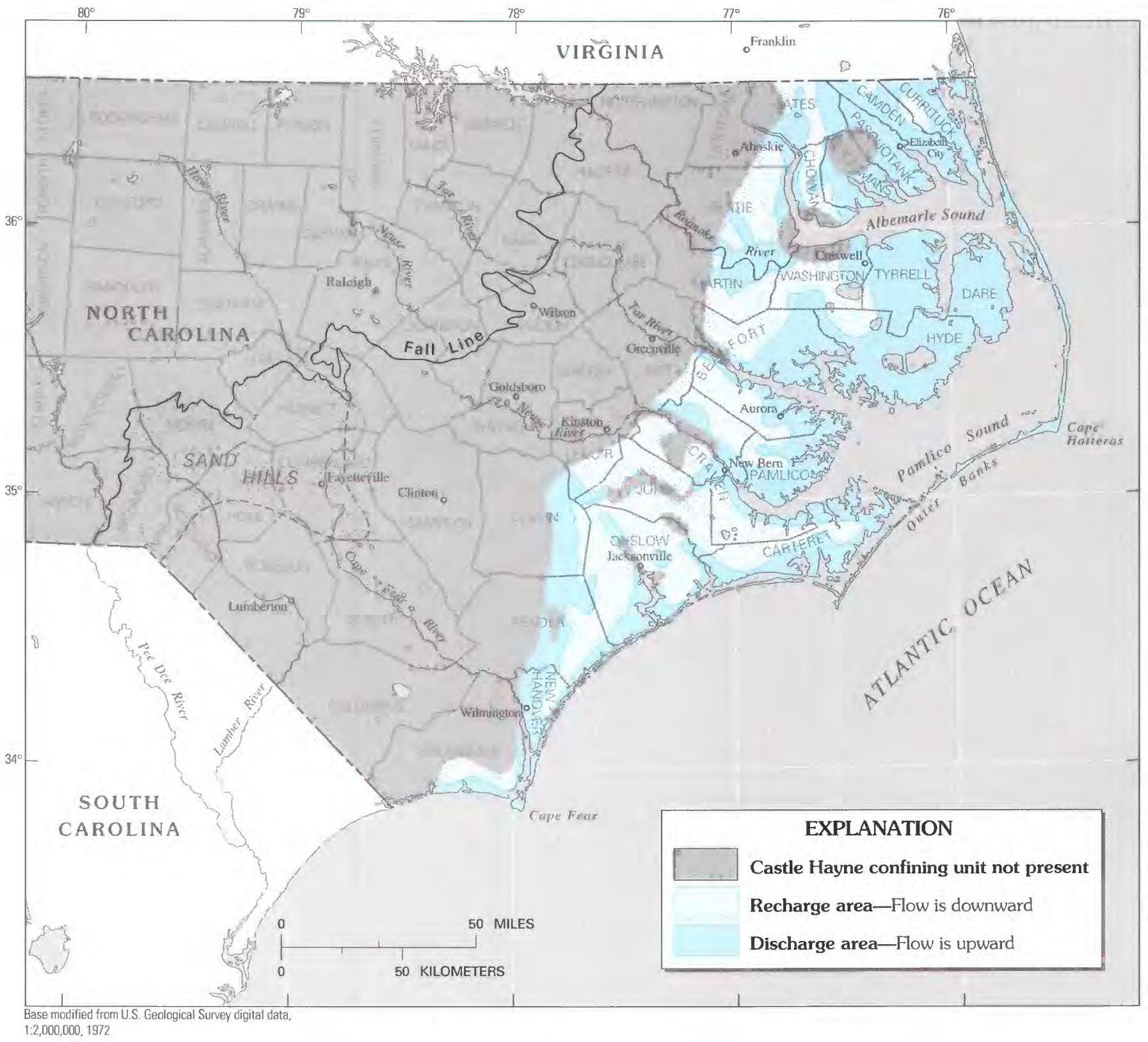

FIGURE 103.--Net vertical flow of water through the Castle Hayne confining unit (CU7) simulated for predevelopment (1900) conditions. 


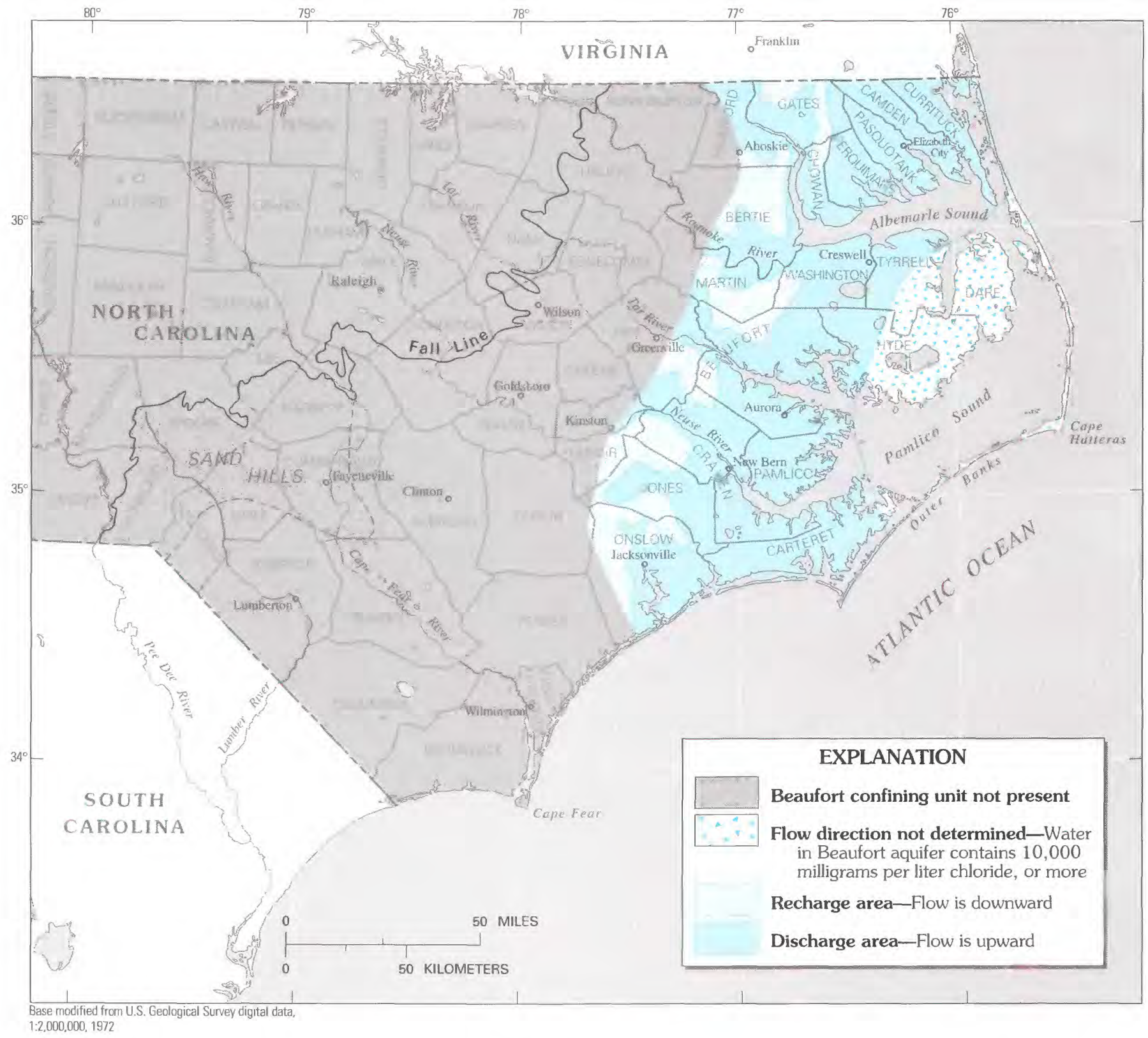

Figure 104.-Net vertical flow of water through the Beaufort confining unit (CU6) simulated for predevelopment (1900) conditions. 


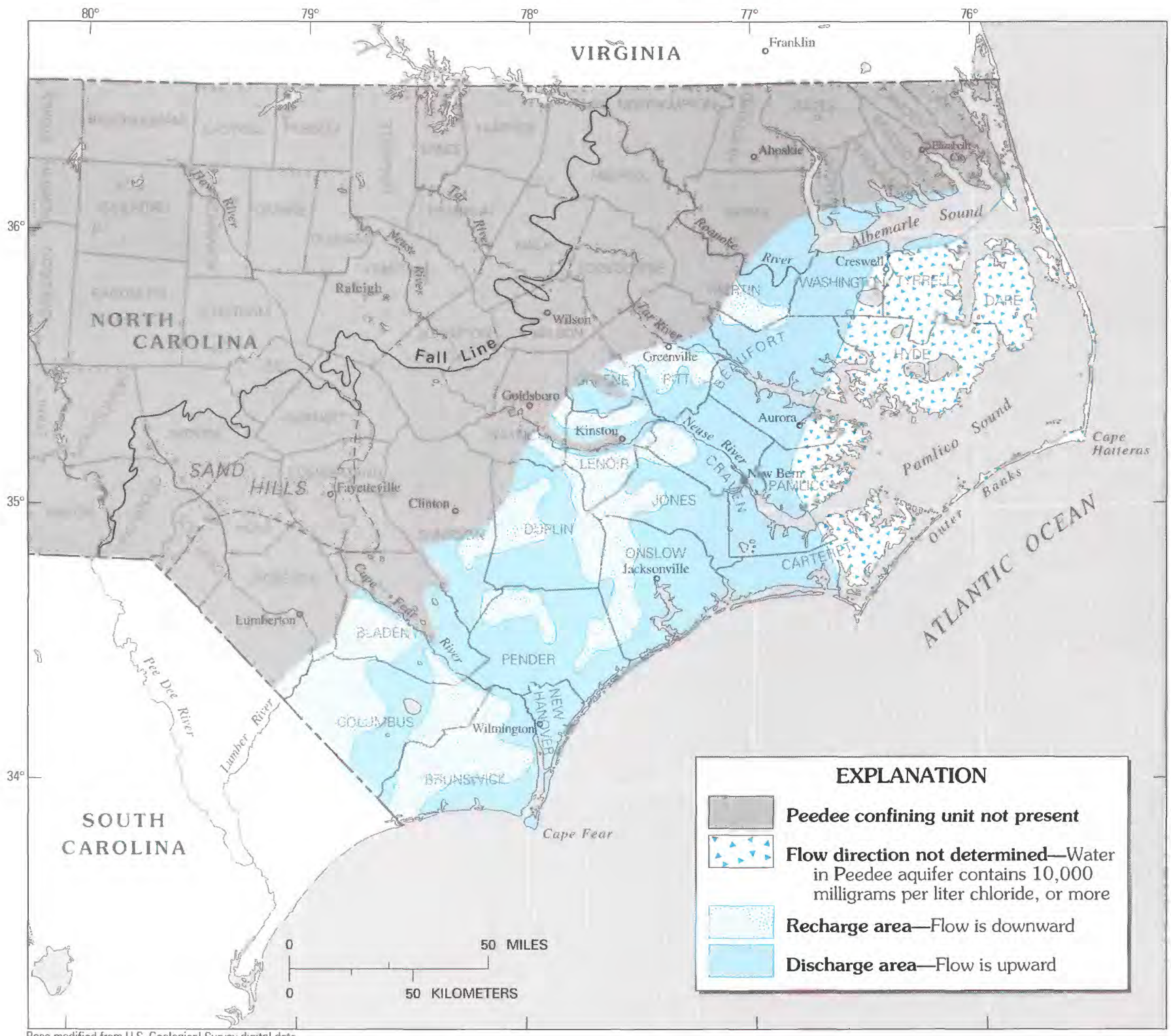

Base modified from U.S. Geological Survey digtal data $1.2,000,000,1972$

FIGURE 105.--Net vertical flow of water through the Peedee confining unit (CU5) simulated for predevelopment (1900) conditions. 


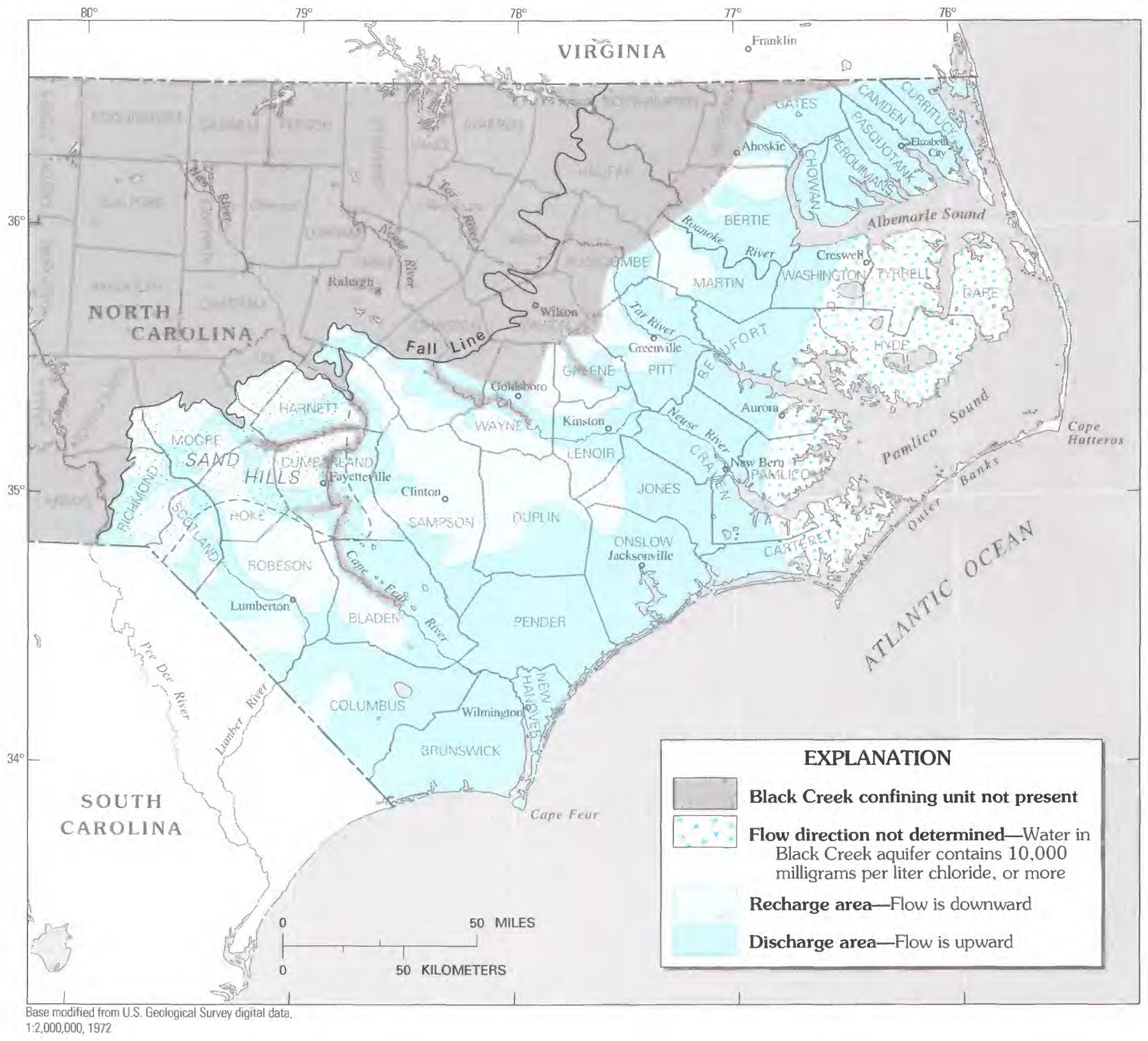

FIGURE 106.-Net vertical flow of water through the Black Creek confining unit (CU4) simulated for predevelopment (1900) conditions. 


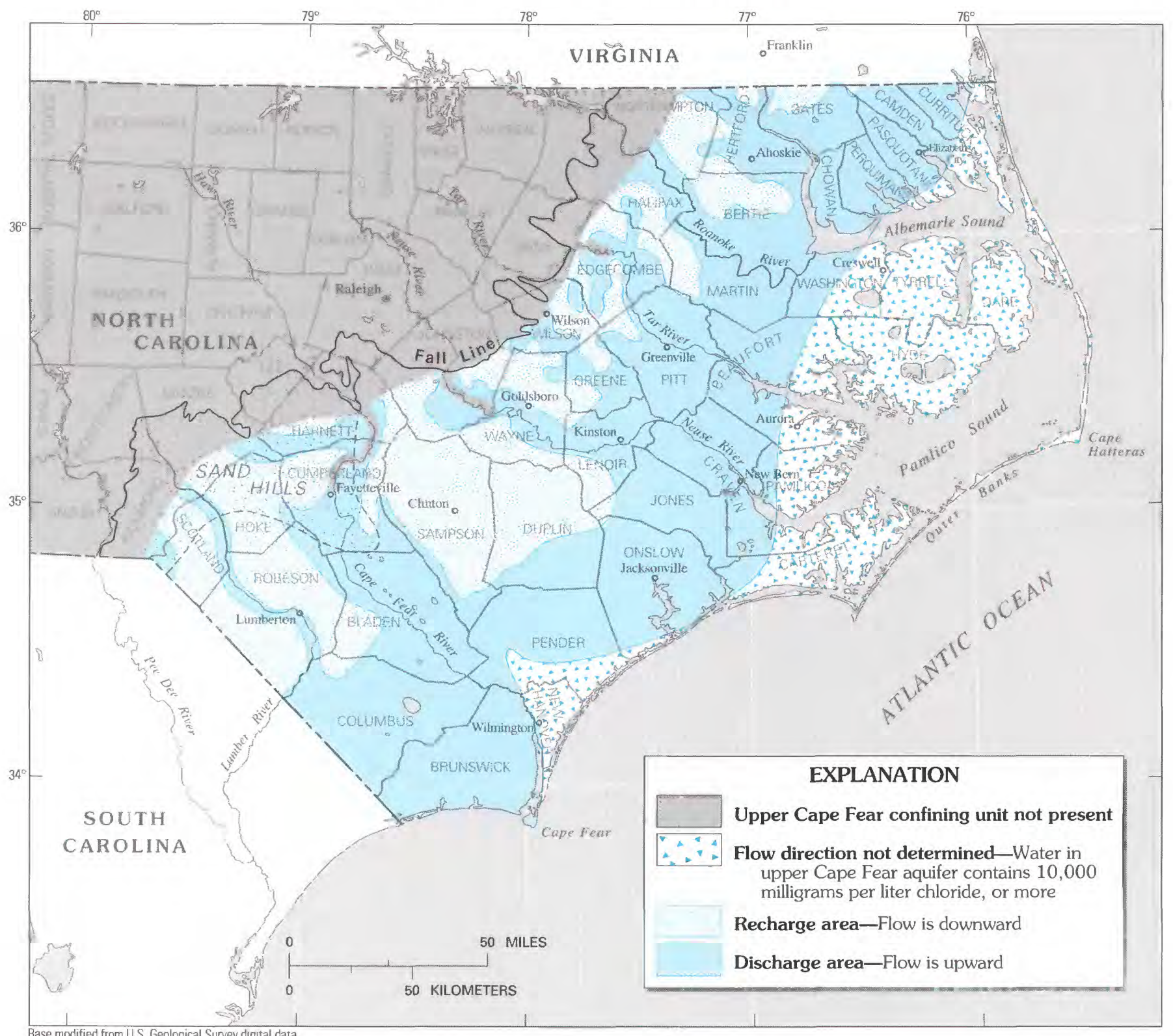

U. Geological Survey digital data

FIGURE 107.-Net vertical flow of water through the upper Cape Fear confining unit (CU3) simulated for predevelopment (1900) conditions. 


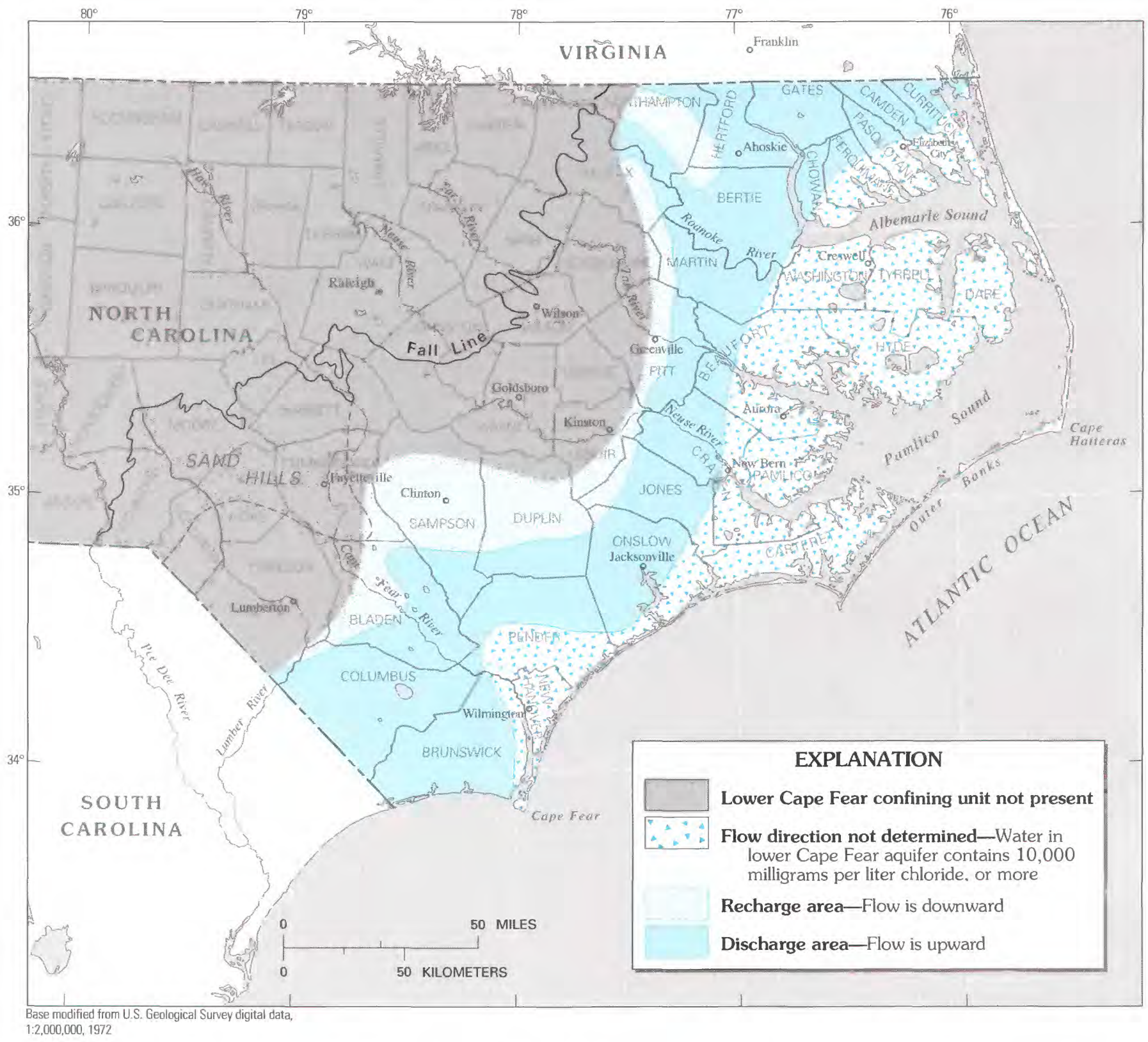

FigURE 108.--Net vertical flow of water through the lower Cape Fear confining unit (CU2) simulated for predevelopment (1900) conditions. 


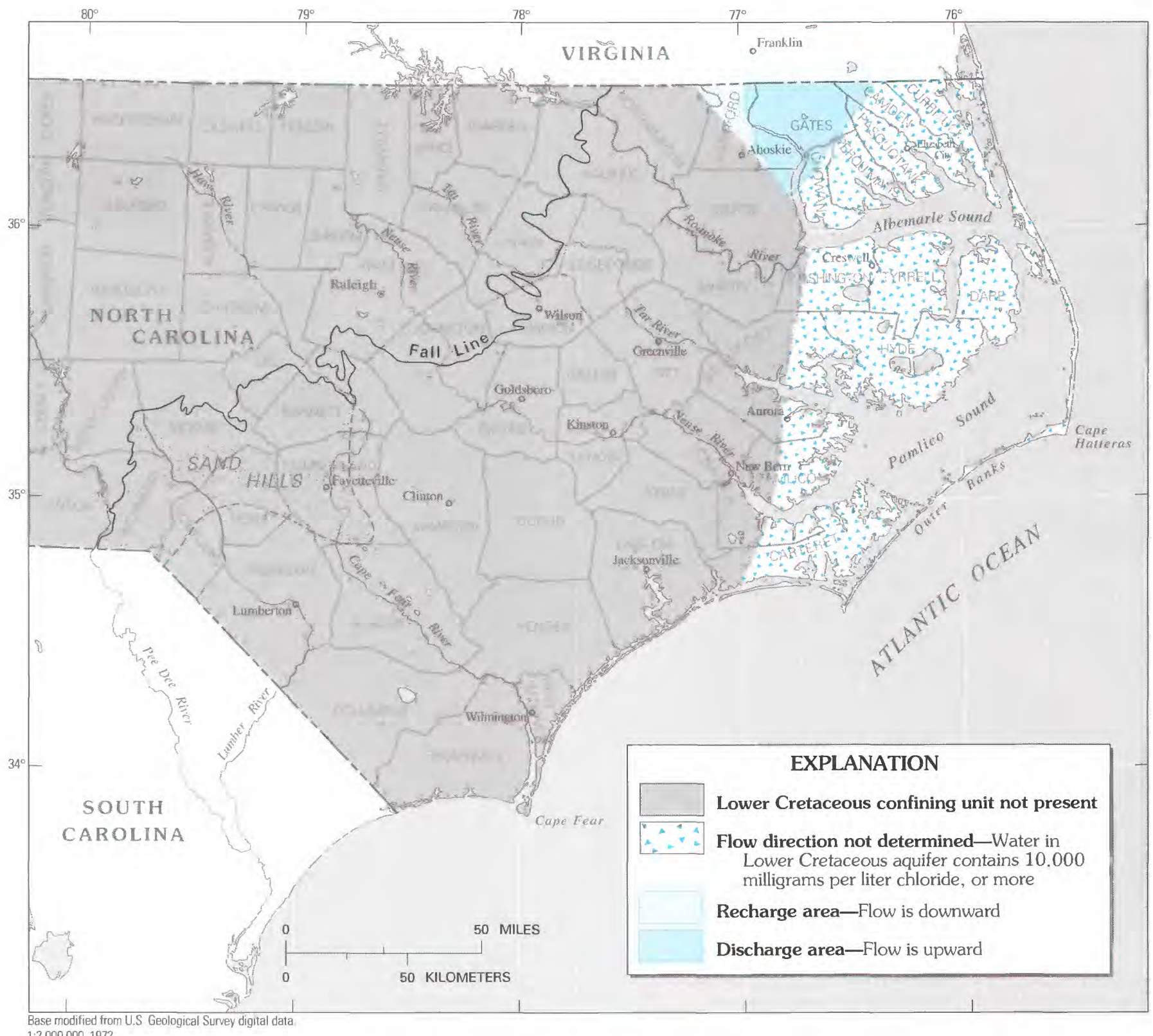
1.2,000,000, 1972

FIGURE 109.-Net vertical flow of water through the Lower Cretaceous confining unit (CU1) simulated for predevelopment (1900) conditions. 


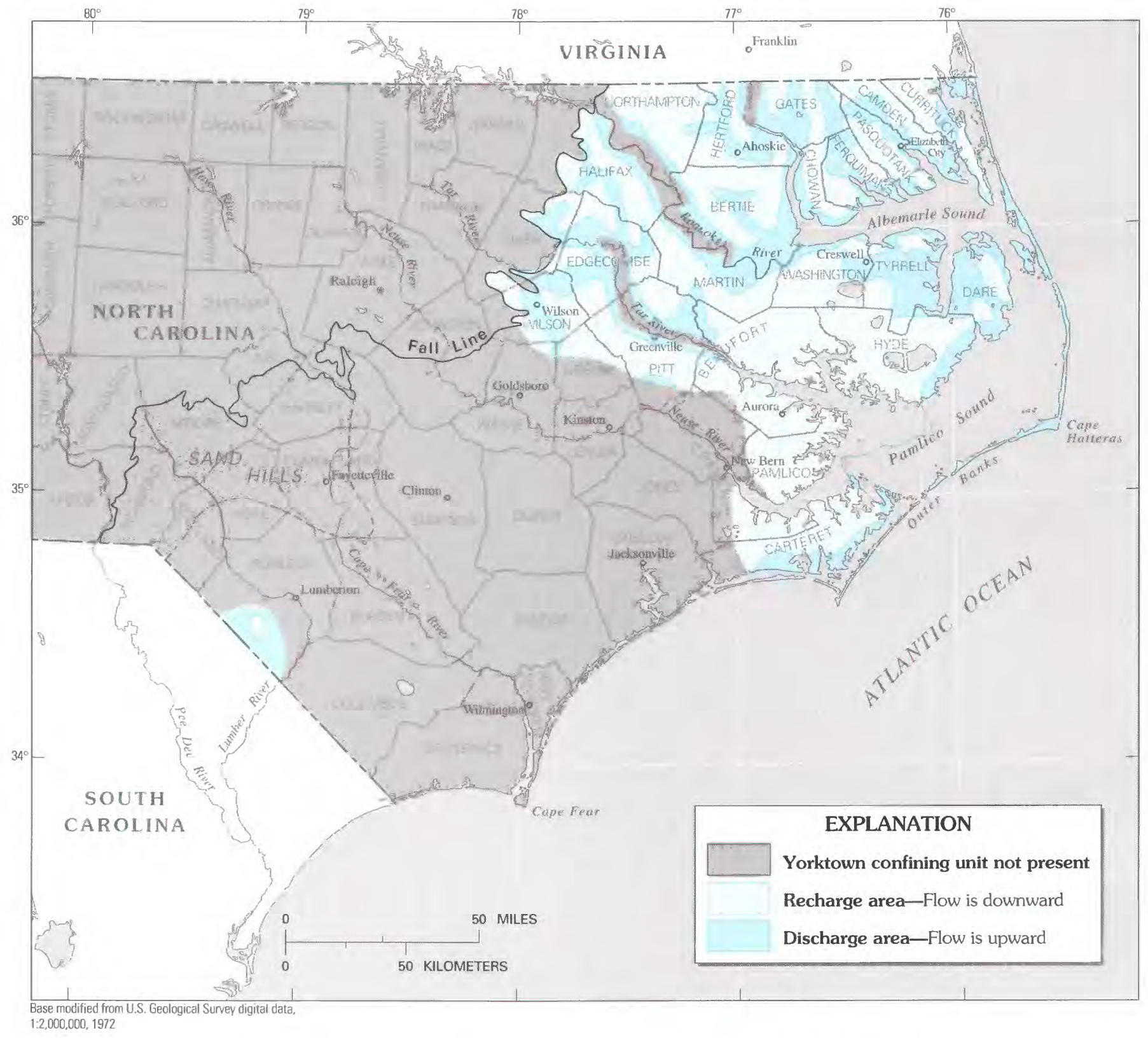

FIGURE 110.-Net vertical flow of water through the Yorktown confining unit (CU9) simulated for 1980 conditions. 


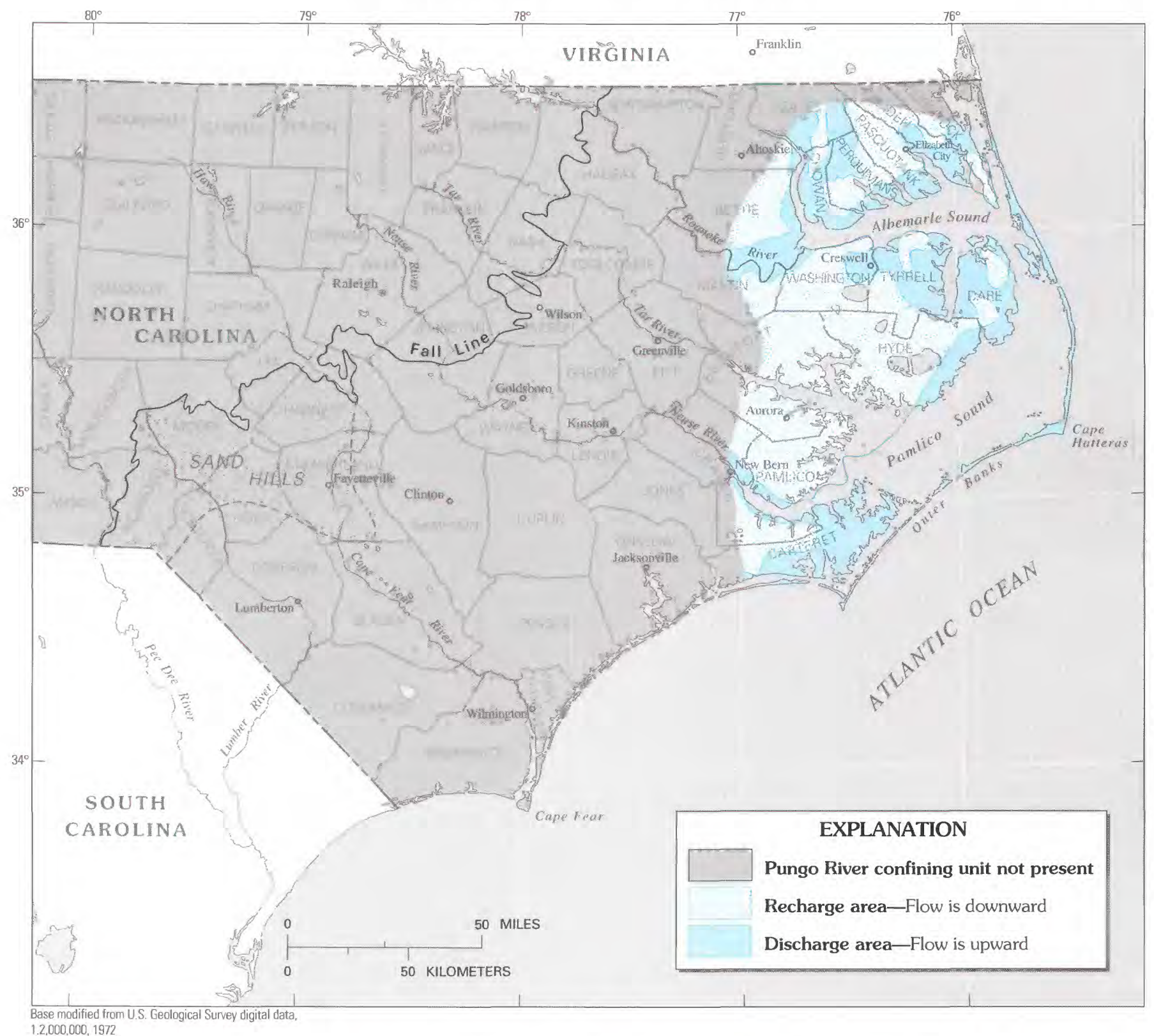

FIGURE 111.-Net vertical flow of water through the Pungo River confining unit (CU8) simulated for 1980 conditions. 


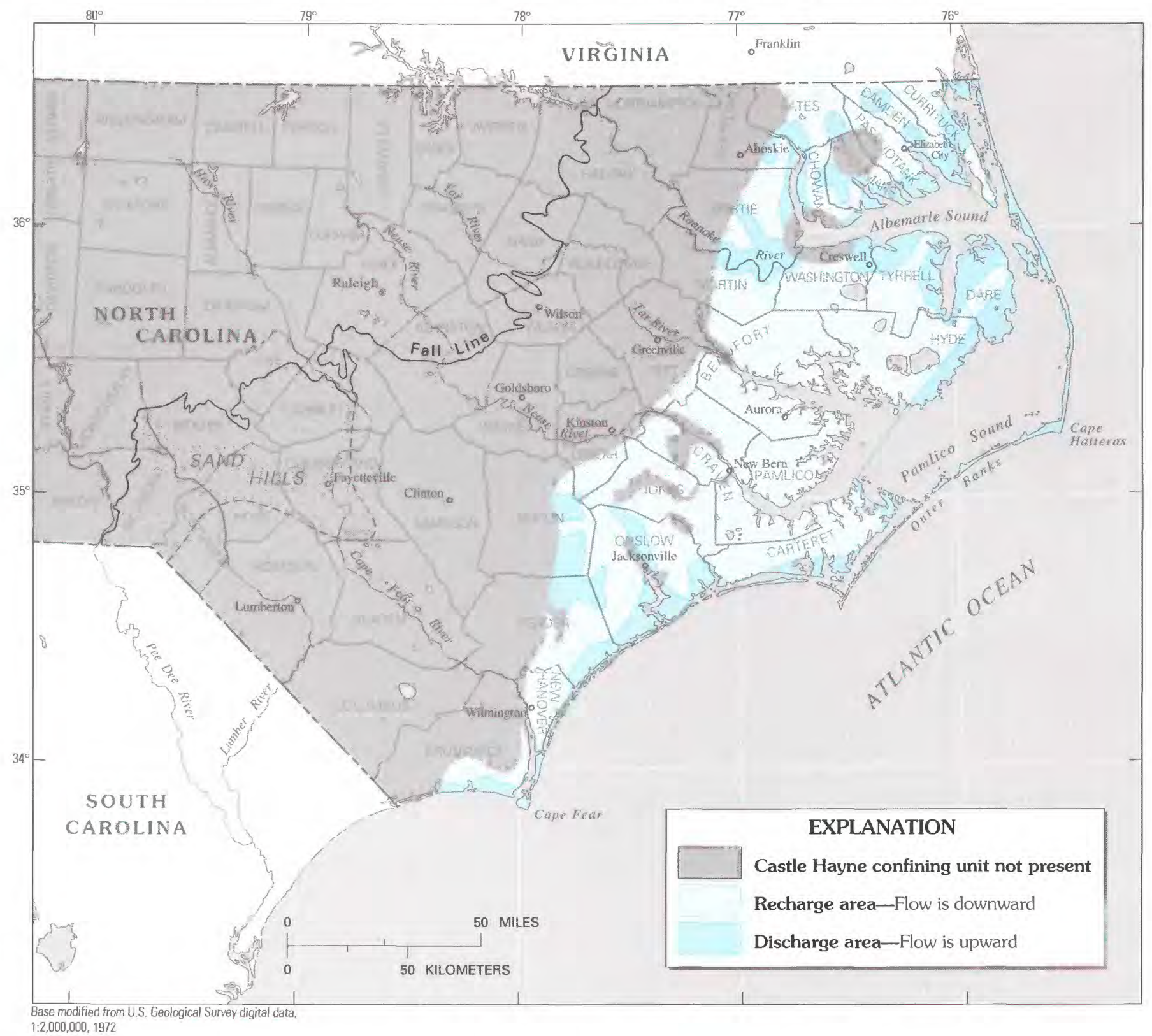

FIGURE 112.-Net vertical flow of water through the Castle Hayne confining unit (CU7) simulated for 1980 conditions. 


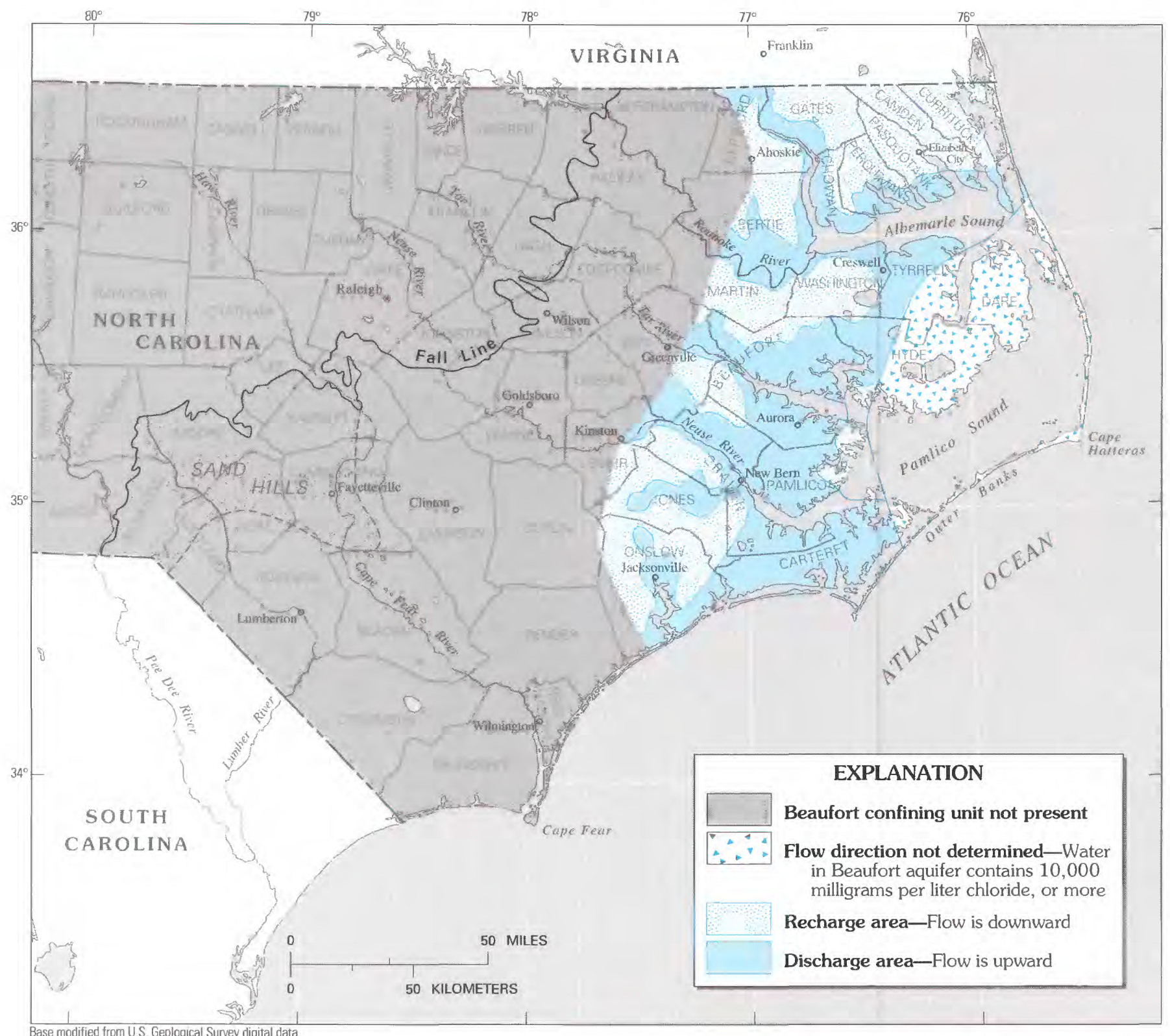

FigURE 113.-Net vertical flow of water through the Beaufort confining unit (CU6) simulated for 1980 conditions. 


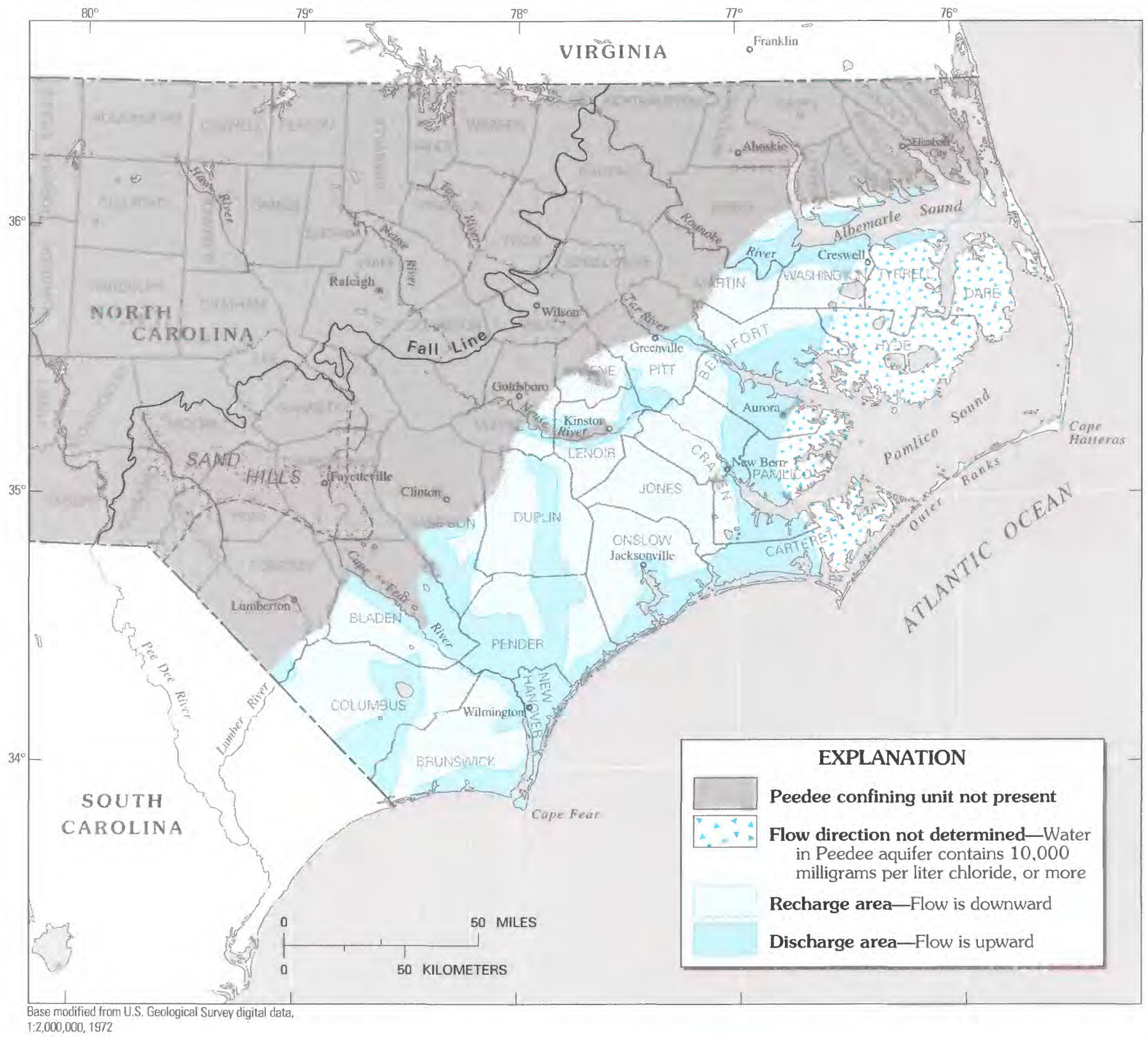

FIGURE 114.--Net vertical flow of water through the Peedee confining unit (CU5) simulated for 1980 conditions. 


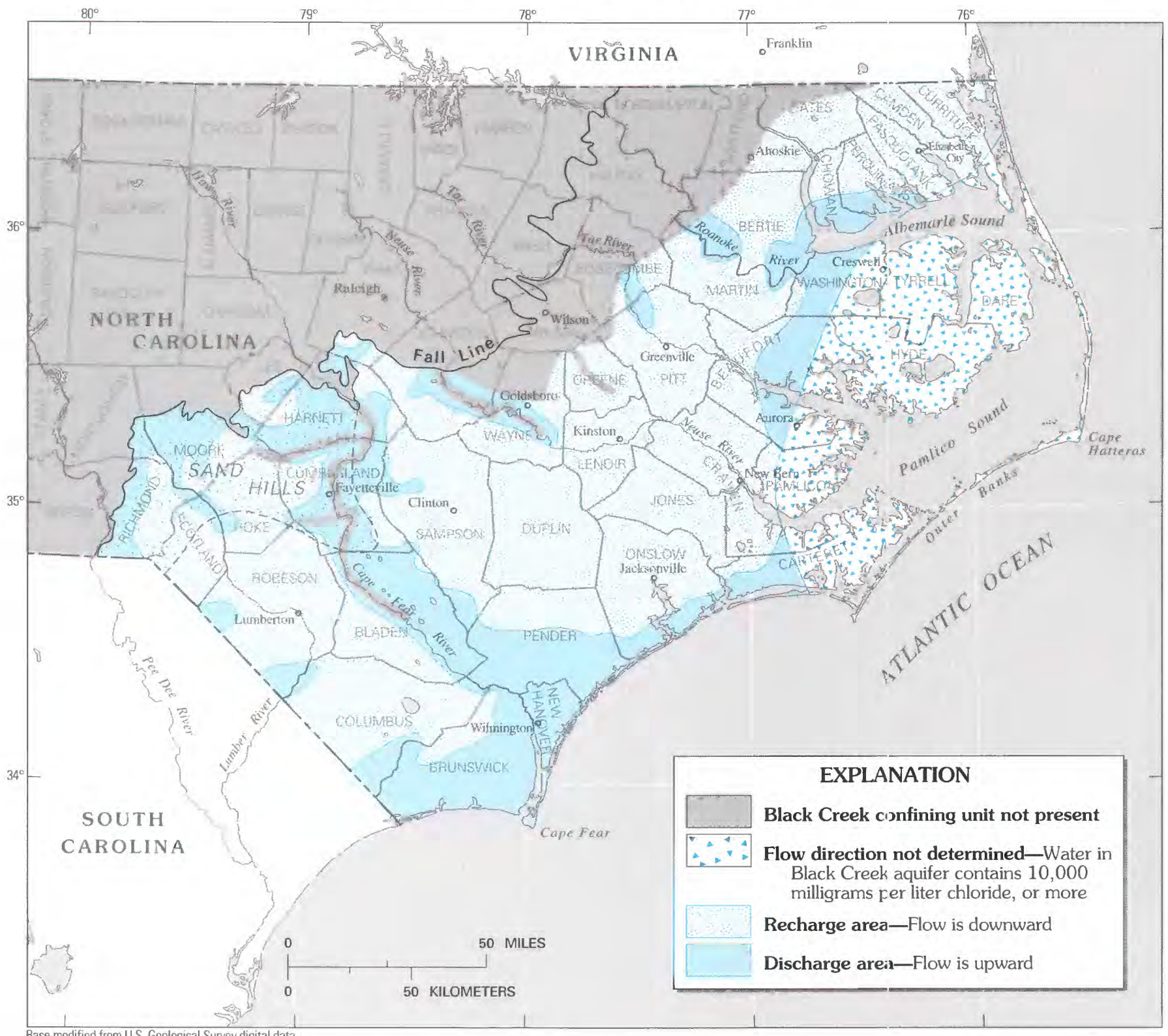

Base modified from U.S. Geological Survey digital data,

FigURE 115-Net vertical flow of water through the Black Creek confining unit (CU4) simulatec for 1980 conditions. 


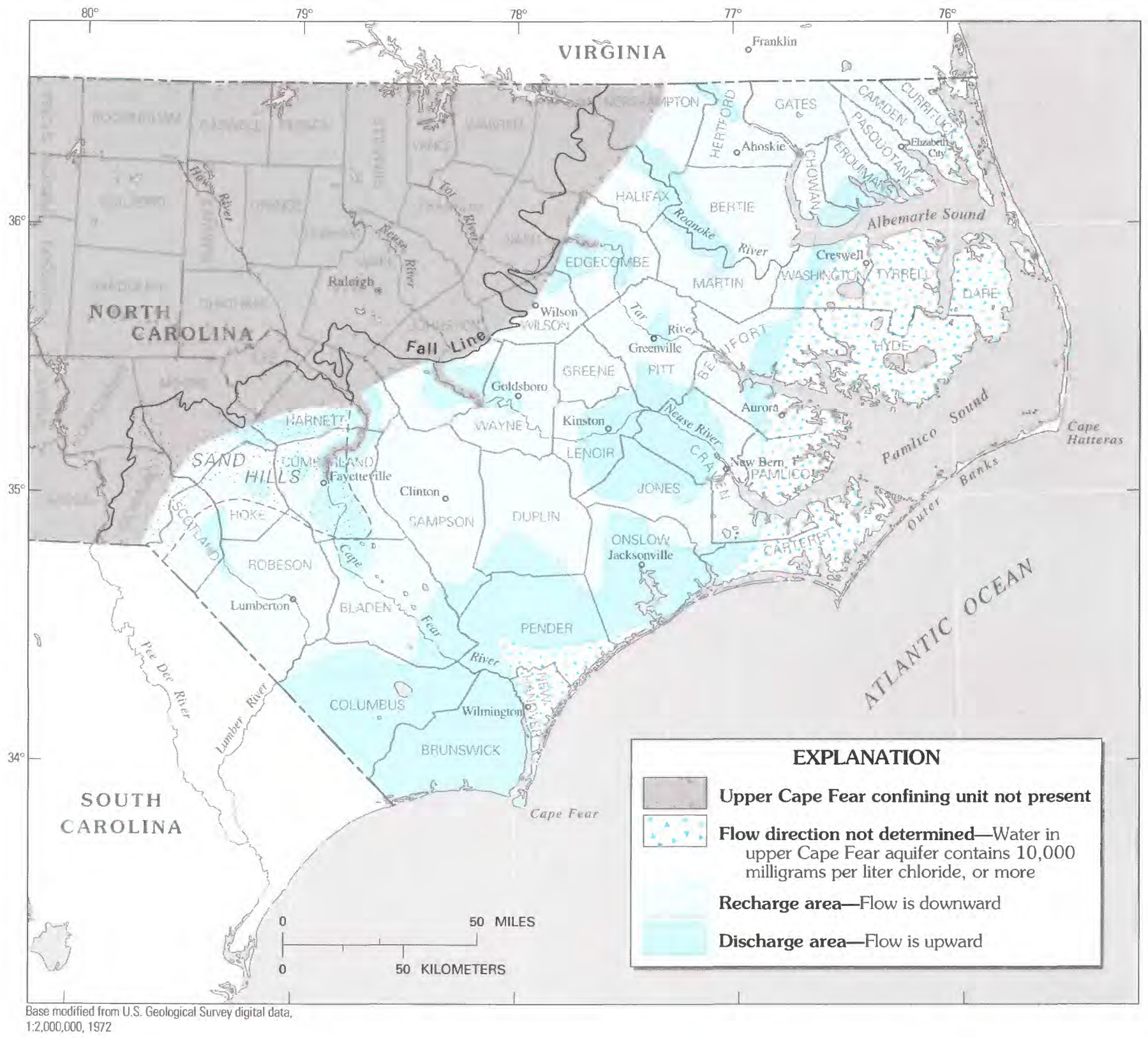

FIGURE 116.--Net vertical flow of water through the upper Cape Fear confining unit (CU3) simulated for 1980 conditions. 


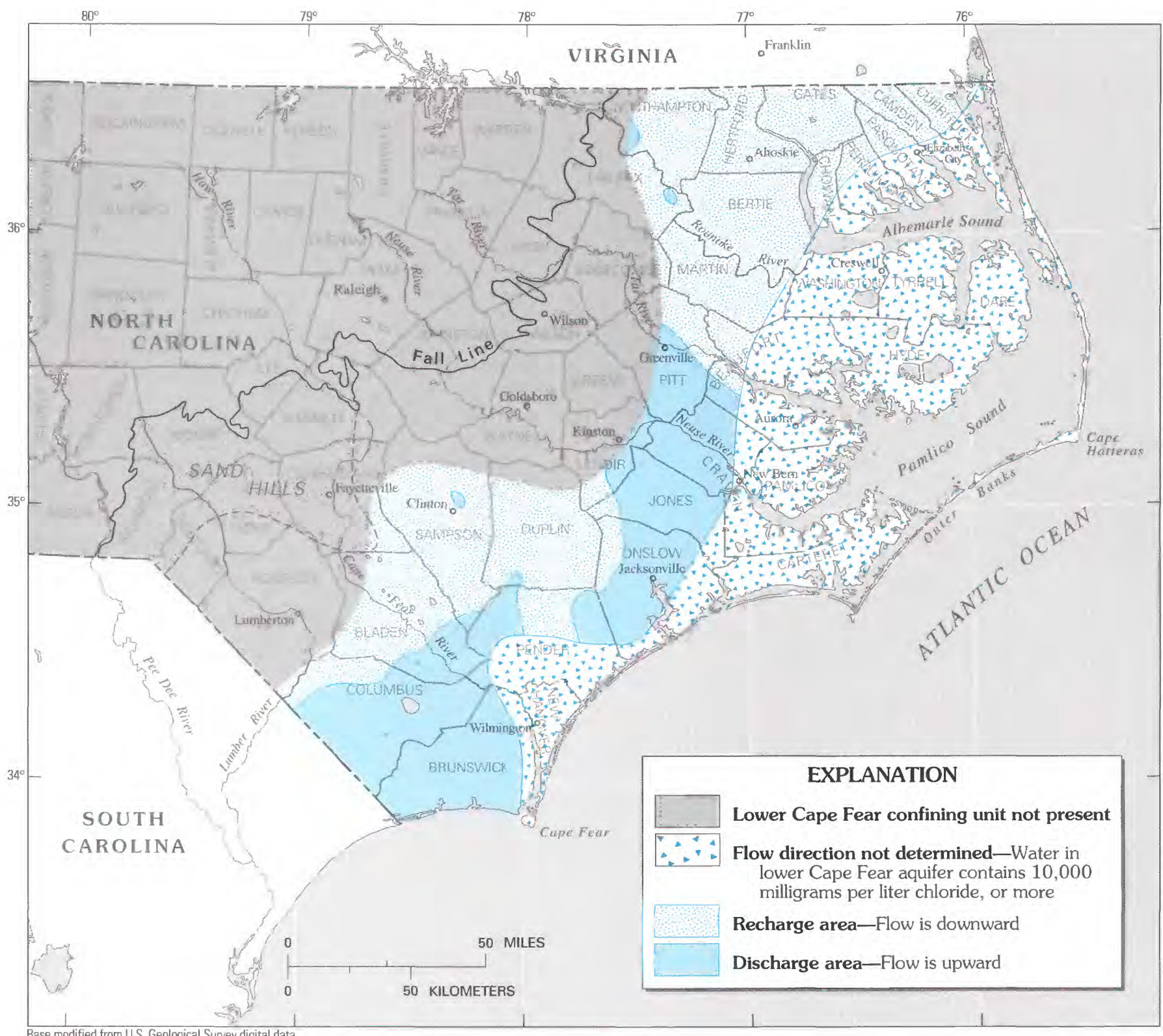

S. Geological Survey digital data,

FigURE 117.-Net vertical flow of water through the lower Cape Fear confining unit (CU2) simulated for 1980 conditions. 


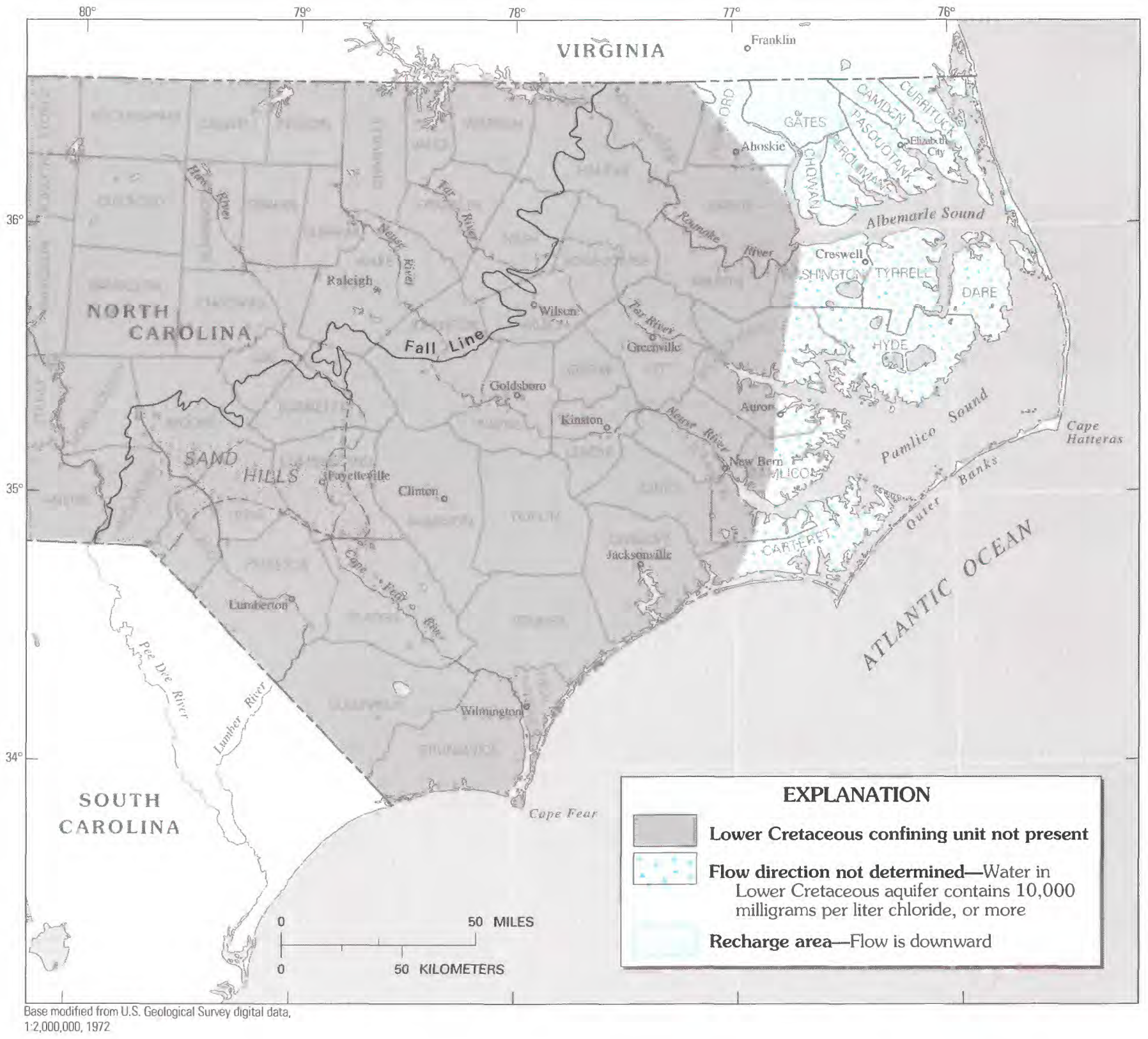

FIGURE 118. - Net vertical flow of water through the Lower Cretaceous confining unit (CU1) simulated for 1980 conditions. 


\section{SUMMARY AND CONCLUSIONS}

A three-dimensional finite-difference digital flow model was developed to simulate ground-water flow in the Coastal Plain aquifer system of North Carolina, covering an area of $25,000 \mathrm{mi}^{2}$. The 10-layer model was developed from a hydrogeologic framework made up of an alternating sequence of aquifers and confining units that dip and thicken in the seaward direction. The model code used was a three-dimensional finite-difference ground-water flow model, and the modeled area was divided into a rectangular grid for each of the 10 layers with varied spacing representing areas ranging from $12.25 \mathrm{mi}^{2}$ to $56.25 \mathrm{mi}^{2}$. The grid and boundary conditions of the mathematical-numerical model were designed to be compatible with a regional model of the entire Northern Atlantic Coastal Plain.

Western and eastern boundaries for each of the model layers were treated as no-flow boundaries. The eastern boundaries were assumed to be along lines of equal concentrations of $10,000 \mathrm{mg} / \mathrm{L}$ of dissolved chloride. Boundaries at the State lines, Virginia to the north and South Carolina to the south, were specified-flux boundaries, the fluxes being provided by the regional model. The upper boundary of each confined aquifer was the bottom of its associated confining unit, which was treated as a head-dependent flux boundary.

For the model as a whole, the upper boundary was the layer representing streams (a constant-head boundary), and the lower boundary was either bedrock or a saltwater-bearing aquifer (no-flow boundary). The treatment of the line representing the $10,000 \mathrm{mg} / \mathrm{L}$ chloride concentration as a no-flow boundary was valid in areas not affected by pumping, but was not valid where effects of pumping extended to the boundary, as in parts of the Beaufort (A6), Black Creek (A4), upper Cape Fear (A3), lower Cape Fear (A2), and Lower Cretaceous (A1) aquifers. In these areas, the model will tend to predict greater drawdown than would actually occur.

Model input consisted of transmissivity and storage coefficient of the aquifers, confining-unit and streambed leakance, ground-water recharge, water-table and stream-surface altitudes, boundary-flux rates, and pumpage. For transient simulations, 10 pumping periods starting in 1900 and running through 1980 were used. Pumping periods ranged in length from 21 years (first pumping period) to 3 years (last pumping period).

A number of calibration simulations were made for the purpose of testing how well the model was able to reproduce measured water levels and as an aid to indicate where adjustments to model parameters were needed. The primary parameters adjusted were leakance of the confining units and, to a lesser extent, transmissivity of the aquifers.
During the calibration procedures, about 240 computed hydrographs were compared with observed hydrographs. Also, computed potentiometric surfaces for various pumping periods were checked with actual water-level data. Adjustments to model parameters were made after careful consideration of whether the adjustments could be justified based on data on the hydrogeologic and ground-water flow systems. The largest changes were in estimates of leakance of confining units and were considered reasonable because the initial values of this parameter were known with less certainty than any other parameters.

For the calibrated model, the maximum transmissivity was about $200,000 \mathrm{ft}^{2} / \mathrm{d}$ in a part of the Castle Hayne aquifer (A7). The smallest vertical hydraulic conductivity of a confining unit for the calibrated model was about $4.1 \times 10^{-6} \mathrm{ft} / \mathrm{d}$ in a part of the lower Cape Fear confining unit. Simulations indicate that a barrier to flow exists in the vicinity of a landward reentrant of water containing $10,000 \mathrm{mg} / \mathrm{L}$ of dissolved chloride in the upper and lower Cape Fear aquifers (A3 and A2) over the Cape Fear arch in the Wilmington area. The barrier is probably the cause of the high hydraulic heads in these two aquifers southwest of the arch in southeastern North Carolina and northeastern South Carolina. The nature of the barrier needs further research but is likely due either to diminished hydraulic conductivity in the area or to the presence of salty water, or both.

The relatively large block size made it difficult to accurately simulate the configuration of the water table in the Sand Hills area. Thus, the model is probably less accurate in this area than in any other area in the North Carolina Coastal Plain.

Sensitivity analysis indicated that the model is especially sensitive to changes in transmissivity in areas where pumping occurs, but regionally the model is more uniformly sensitive to leakance through the confining units. Sensitivity of the model to changes in storage coefficient of the confined aquifers is slight and, as with transmissivity, is greatest near the pumping centers.

Under predevelopment (1900) conditions, average recharge from precipitation to the surficial aquifer varied areally from about $12 \mathrm{in} / \mathrm{yr}$ in areas with clay soils to 20 in/yr in areas with sandy soils. Most of this moved directly to streams and only about $1 \mathrm{in} / \mathrm{yr}$ moved downward into the confined aquifer system. Generally, recharge to the confined aquifer system took place mostly in updip interstream areas, and discharge occurred in streams and stream valleys and in downdip coastal areas. Hydrologic analysis of the aquifer system based on simulations indicates that the overall water budget has changed little from predevelopment conditions in 1900 to development conditions in 1980 . Pumpage from large users increased from zero to $302 \mathrm{ft}^{3} / \mathrm{s}$ during 
that period, which amounts to about 1.2 percent of the recharge to the ground-water system of $25,703 \mathrm{ft} 3 / \mathrm{s}$. Simulation results indicate that water lost to the aquifer system through pumping is largely offset by reductions in base flow of streams and, to a lesser extent, by reductions in aquifer storage. By 1980, contribution from aquifer storage was about $14 \mathrm{ft}^{3} / \mathrm{s}$, or about 4.8 percent of pumpage.

Although the effect of pumping on the overall water budget is relatively small, water levels in the North Carolina Coastal Plain aquifer system have declined dramatically in parts of some aquifers since 1900 (more than $135 \mathrm{ft}$ in some locations) due to pumping stresses. The three principal areas of long-term decline in water level are in the Lower Cretaceous (A1) and lower Cape Fear (A2) aquifers in northeastern North Carolina in response to withdrawals at Franklin, Va.; in the lower Cape Fear (A2), upper Cape Fear (A3), and Black Creek (A4) aquifers in the central North Carolina Coastal Plain, where pumping occurs at several sites; and in the Beaufort (A6) and Castle Hayne (A7) aquifers in Beaufort County, where there are large withdrawals for open-pit phosphate mining and chemical manufacturing.

Since 1900, water levels have declined less than $10 \mathrm{ft}$ in the surficial (A10) and Yorktown (A9) aquifers; this is also true of the updip parts of most of the other aquifers where major withdrawals were not occurring in 1980. Simulations to the year 2000 with a 3-percent annual increase in withdrawals at 1980 pumping locations gave virtually the same results as the 1980 simulations of the same two shallow aquifers and updip parts of the other aquifers. The year 2000 simulations indicated significant local water-level declines in lower confined aquifers, but on a cell basis, not below the tops of the aquifers.

Directions of vertical flow through confining units have been altered in many areas since 1900. In 1900, vertical ground-water flow through confining units was generally downward in interstream areas and upward in major stream valleys and in coastal areas. Ground-water pumpage substantially altered that pattern in several areas. The most widespread change caused ground water to move downward into pumped aquifers in areas where it had moved upward in predevelopment times. By 1980 , areas of downward movement commonly occurred in major stream valleys. Areas of downward movement also extended farther coastward in 1980 than in 1900 in confining units overlying extensively developed aquifers.

\section{SELECTED REFERENCES}

Aucott, W.R., Davis, M.E., and Speiran, G.K., 1987, Geohydrologic framework of the Coastal Plain aquifers of South
Carolina: U.S. Geological Survey Water-Resources Investigations Report 85-4271.

Aucott, W.R., and Speiran, G.K., 1985, Ground-water flow in the Coastal Plain aquifers of South Carolina: Ground Water, v. 23 , no. 6, p. 736-745.

Beck, M.B., and van Straten, Gerrit, eds., 1983, Uncertainty and forecasting of water quality: New York, Springer-Verlag, $386 \mathrm{p}$.

Blankenship, R.R., 1965, Reconnaissance of ground-water resources of the Southport-Elizabethtown area, North Carolina: North Carolina Department of Water Resources Ground-Water Bulletin 6, $47 \mathrm{p}$.

Brown, D.L., and Cosner, O.J., 1974, Ground-water conditions in the Franklin area, southeastern Virginia: U.S. Geological Survey Hydrologic Investigations Atlas HA-538, 3 sheets.

Brown, P.M., 1958, Well logs from the Coastal Plain of North Carolina: North Carolina Department of Conservation and Development Bulletin 72, $68 \mathrm{p}$.

-1959 , Geology and ground-water resources in the Greenville area, North Carolina: North Carolina Department of Conservation and Development Bulletin 73, $87 \mathrm{p}$.

Brown, P.M., Miller, J.A., and Swain, F.M., 1972, Structural and stratigraphic framework and spatial distribution of the permeability of the Atlantic Coastal Plain, New York to North Carolina: U.S. Geological Survey Professional Paper 796, $79 \mathrm{p}$.

Clark, W.B., Miller, B.L., Stephenson, L.W., Johnson, B.L., and Parker, H.N., 1912, The Coastal Plain of North Carolina: North Carolina Geological and Economic Survey Bulletin $3,372 \mathrm{p}$.

Coble, R.W., Giese, G.L., and Winner, M.D., Jr., 1987, Application of regional aquifer-system analysis study results to ground-water management in North Carolina, in Vecchioli, John, and Johnson, A.I., eds., Regional aquifer systems of the United States, Aquifers of the Atlantic and Gulf Coastal Plain: American Water Resources Association Monograph Series 9, p. 39-49.

Cosner, O.J., 1975, A predictive computer model of the Lower Cretaceous aquifer, Franklin area, southeastern Virginia: U.S. Geological Survey Water-Resources Investigations Report 51-74, 62 p.

Daniel, J.F., 1976, Estimating evapotranspiration from streamflow records: Water Resources Research, v. 12, p. 360-364.

DeWiest, R.J.M., Sayre, A.N., and Jacob, C.E., 1967, Evaluation of potential impact of phosphate mining on ground-water resources of eastern North Carolina: Board of Consultants Report to North Carolina Department of Water Resources, $167 \mathrm{p}$.

Eder, B.K., Davis, J.M., and Robinson, P.J., 1983, Variations in monthly precipitation over North Carolina: University of North Carolina Water Resources Research Institute Report 83-185, $50 \mathrm{p}$.

Emsellem, Y., and deMarsily, G., 1971, An automatic solution for the inverse problem: Water Resources Research, v. 7, no. 5, p. 1264-1283.

Fenneman, N.M., 1938, Physiography of eastern United States: New York, McGraw-Hill, 714 p. 
Floyd, E.O., and Peace, R.R., 1974, An appraisal of the ground-water resources of the upper Cape Fear River basin, North Carolina: North Carolina Department of Water and Air Resources Ground-Water Bulletin 20, 17 p.

Franke, O.L., Reilly, T.E., and Bennett, G.D., 1984, Definition of boundary and initial conditions in the analysis of saturated ground-water flow systems-An introduction: U.S. Geological Survey Open-File Report 84-458, 26 p.

Giese, G.L., Wilder, H.B., and Parker, G.G., Jr., 1985, Hydrology of major estuaries and sounds of North Carolina: U.S. Geological Survey Water-Supply Paper 2221, 108 p.

Hamilton, P.A., and Larson, J.D., 1988, Hydrogeology and analysis of the ground-water flow system in the Coastal Plain of southeastern Virginia: U.S. Geological Survey WaterResources Investigations Report 87-4240, 175 p.

Harris, W.H., and Wilder, H.B., 1966, Geology and groundwater resources of the Hertford-Elizabeth City area, North Carolina: North Carolina Department of Water Resources Ground-Water Bulletin 10,89 p.

Harsh, J.F., and Laczniak, R.J., 1990, Conceptualization and analysis of ground-water flow system in the Coastal Plain [aquifers] of Virginia and adjacent parts of Maryland and North Carolina: U.S. Geological Survey Professional Paper 1404-F, 100 p.

Heath, R.C., 1980, Basic elements of ground-water hydrology with reference to conditions in North Carolina: U.S. Geological Survey Water-Resources Investigations Open-File Report 80-44, 86 p.

Hitchon, B., 1969, Fluid flow in the western Canada sedimentary basin, 1, Effect of topography: Water Resources Research, v. 5, no. 1, p. 186-195.

Kimrey, J.O., 1965, Description of the Pungo River Formation in Beaufort County, North Carolina: North Carolina Department of Conservation and Development, Division of Mineral Resources Bulletin 79, $131 \mathrm{p}$.

Layne-Western Company, Inc., 1983, Virginia/North Carolina analog model study: Kansas City, Kansas, v. 1, 131 p.

Leahy, P.P., 1982, A three-dimensional ground-water flow model modified to reduce computer memory requirements and better simulate confining bed and aquifer pinchouts: U.S. Geological Survey Water-Resources Investigations Report 82-4023, $59 \mathrm{p}$.

Leahy, P.P., and Martin, Mary, 1993, Geohydrology and simulation of ground-water flow in the northern Atlantic Coastal Plain aquifer system: U.S. Geological Survey Professional Paper 1404-K, 81 p., 22 pls.

LeGrand, H.E., 1955, Brackish water and its structural implications in the Great Carolina Ridge, North Carolina: American Association of Petroleum Geologists Bulletin, v. 39, no. 10, p. 2020-2037.

-1960 , Geology and ground-water resources of the Wilmington-New Bern area: North Carolina Department of Water Resources Ground-Water Bulletin 1, 80 p.

1961, Summary of geology of Atlantic Coastal Plain: American Association of Petroleum Geologists Bulletin, v. 45 , no. 9, p. 1557-1571.

1964, Hydrogeologic framework of the Gulf and Atlantic Coastal Plain: Southeastern Geology, v. 5, no. 4, p. 177-194.
-1976, Hydrologic implications of the 1886 Charleston earthquake [abs.]: Geological Society of America Abstracts with Programs, v. 8, no. 2, p. 216.

Lohman, S.W., 1972, Ground-water hydraulics: U.S. Geological Survey Professional Paper 708, 70 p.

Martin, Mary, 1990, Ground-water flow in the New Jersey Coastal Plain: U.S. Geological Survey Open-File Report $87-528,182 \mathrm{p}$.

-in press, Ground-water flow in the New Jersey Coastal Plain: U.S. Geological Survey Professional Paper 1404-H.

Meisler, Harold, 1981, Preliminary delineation of salty ground water in the Northern Atlantic Coastal Plain: U.S. Geological Survey Open-File Report 81-71, 25 p.

-1986, Northern Atlantic Coastal Plain regional aquifer-system study, in Sun, R.J., ed., Regional aquifer-system analysis program of the U.S. Geological Survey, summary of projects, 1978-84: U.S. Geological Survey Circular 1002, p. 168-194.

1989, The occurrence and geochemistry of salty ground water in the Northern Atlantic Coastal Plain: U.S. Geological Survey Professional Paper 1404-D, 51 p., 6 pls.

Meng, A.A., III, and Harsh, J.F., 1988, Hydrogeologic framework of the Virginia Coastal Plain: U.S. Geological Survey Professional Paper 1404-C, 82 p., 4 pls.

Morris, D.A., and Johnson, A.I., 1967, Summary of hydrologic and physical properties of rock and soil materials, as analyzed by the Hydrologic Laboratory of the U.S. Geological Survey 1948-60: U.S. Geological Survey Water-Supply Paper 1839-D, 42 p.

Mundorff, M.J., 1946, Ground-water in the Halifax area, North Carolina: North Carolina Department of Conservation and Development Bulletin 51, 76 p.

Narkunas, James, 1980, Groundwater evaluation in the central Coastal Plain of North Carolina: Raleigh, N.C., North Carolina Department of Natural Resources and Community Development, $119 \mathrm{p}$.

Nelson, P.F., 1964, Geology and ground-water resources of the Swanquarter area: North Carolina Department of Water Resources Ground-Water Bulletin 4, 79 p.

-1976, Interim report on ground-water conditions in capacity-use area no. 1, central Coastal Plain, North Carolina, 1974-75: North Carolina Department of Natural and Economic Resources Report of Investigations 13, 55 p.

Nelson, P.F., and Barksdale, R.G., 1965, Interim report on the ground-water resources of the Kinston area, North Carolina: North Carolina Department of Water Resources Ground-Water Circular 10,31 p.

North Carolina Department of Natural Resources and Community Development, 1983, Use of water in North CarolinaSelf-supplied industrial use for 1981: Raleigh, N.C., Office of Water Resources publication, $42 \mathrm{p}$.

North Carolina Department of Natural Resources and Community Development and U.S. Water Resources Council, 1983, Survey of agricultural irrigation 1982-Lower Cape Fear River basin: Raleigh, N.C., 31 p.

Peek, H.M., 1977, Interim report on ground-water conditions in northeastern North Carolina: North Carolina Department of Natural Resources and Community Development Report of Investigations 15, $29 \mathrm{p}$. 
Peek, H.M., and Register, L.A., 1975, A preliminary report on anomalous pressure in deep artesian aquifers in southeastern North Carolina: North Carolina Department of Natural and Economic Resources Report of Investigations 10, $20 \mathrm{p}$.

Robison, T.M., 1977, Public water supplies of North Carolina; Part 4, Northern Coastal Plain: Raleigh, N.C., North Carolina Department of Natural and Economic Resources, $218 \mathrm{p}$.

Robison, T.M., and Mann, L.T., Jr., 1977, Public water supplies of North Carolina; Part 5, Southern Coastal Plam: Raleigh, N.C., North Carolina Department of Natural Resources and Community Development, $333 \mathrm{p}$.

Rorabaugh, M.I., 1964, Estimating changes in bank storage and ground-water contribution to streamflow: International Association of Scientific Hydrology Publication 63, p. 432-441.

Schipf, R.G., 1961, Geology and ground-water resources of the Fayetteville area: North Carolina Department of Water Resources Ground-Water Bulletin 3,99 p.

Sherwani, J.K., 1973, Computer simulation of ground-water aquifers of the Coastal Plain of North Carolina: University of North Carolina Water Resources Research Institute Report 75, $126 \mathrm{p}$.

Steinhorst, R.K., Hurt, H.W., Innis, G.S., and Haydock, K.P., 1978, Sensitivity analysis of the ELM model, in Innis, G.S., ed., Grassland simulation model: New York, Springer-Verlag, p. 231-256.

Stephenson, L.W., and Rathbun, M.J., 1923, The Cretaceous formations of North Carolina: North Carolina Geological and Economic Survey, v. 5, pt. 1, 604 p.
Stuckey, J.L., 1965, North Carolina-Its geology and mineral resources: Raleigh, N.C., North Carolina Department of Conservation and Development, $550 \mathrm{p}$.

Tant, P.L., Byrd, H.J., and Horton, R.E., 1974, General soil map of North Carolina: U.S. Soil Conservation Service map, scale 1:1,000,000.

Tomovic, R., 1962, Sensitivity analysis of dynamic systems: New York, McGraw-Hill, $142 \mathrm{p}$.

Trescott, P.C., 1975, Documentation of finite-difference model for simulation of three-dimensional ground-water flow: U.S. Geological Survey Open-File Report 75-438, 48 p.

Trescott, P.C., and Larson, S.P., 1976, Supplement to Open-File Report 75-438, Documentation of finite-difference model for simulation of three-dimensional ground-water flow: U.S. Geological Survey Open-File Report 76-591, 21 p.

Trescott, P.C., Pinder, G.F., and Larson, S.P., 1976, Finite-difference model for aquifer simulation in two dimensions with results of numerical experiments: U.S. Geological Survey Techniques of Water-Resources Investigations, Book 7, chap. $\mathrm{C} 1,116 \mathrm{p}$.

Wilder, H.B., Robison, T.M., and Lindskov, K.L., 1978, Water resources of northeast North Carolina: U.S. Geological Survey Water-Resources Investigations 77-81, 113 p.

Wilder, H.B., and Simmons, C.E., 1982, Program for evaluating stream quality in North Carolina: U.S. Geological Survey Water-Supply Paper 2185-A, 15 p.

Winner, M.D., Jr., and Coble, R.W., 1989, Hydrogeologic framework of the North Carolina Coastal Plain aquifer system: U.S. Geological Survey Open-File Report 87-690, 155 p. 1996, Hydrogeologic framework of the North Carolina Coastal Plam: U.S. Geological Survey Professional Paper 1404-I, 106 p., 24 pls. 


\section{SELECTED SERIES OF U.S. GEOLOGICAL SURVEY PUBLICATIONS}

\section{Periodical}

Preliminary Determination of Epicenters (issued monthly).

\section{Technical Books and Reports}

Professional Papers are mainly comprehensive scientific reports of wide and lasting interest and importance to professional scientists and engineers. Included are reports on the results of resource studies and of topographic, hydrologic, and geologic investigations. They also include collections of related papers addressing different aspects of a single scientific topic.

Bulletins contain significant data and interpretations that are of lasting scientific interest but are generally more limited in scope or geographic coverage than Professional Papers. They include the results of resource studies and of geologic and topographic investigations, as well as collections of short papers related to a specific topic.

Water-Supply Papers are comprehensive reports that present significant interpretive results of hydrologic investigations of wide interest to professional geologists, hydrologists, and engineers. The series covers investigations in all phases of hydrology, including hydrogeology, availability of water, quality of water, and use of water.

Circulars present administrative information or important scientific information of wide popular interest in a format designed for distribution at no cost to the public. Information is usually of short-term interest.

Water-Resources Investigations Reports are papers of an interpretive nature made available to the public outside the formal USGS publications series. Copies are reproduced on request unlike formal USGS publications, and they are also available for public inspection at depositories indicated in USGS catalogs.

Open-File Reports include unpublished manuscript reports, maps, and other material that are made available for public consultation at depositories. They are a nonpermanent form of publication that may be cited in other publications as sources of information.

\section{Maps}

Geologic Quadrangle Maps are multicolor geologic maps on topographic bases in 7.5- or 15-minute quadrangle formats (scales mainly 1:24,000 or 1:62,500) showing bedrock, surficial, or engineering geology. Maps generally include brief texts; some maps include structure and columnar sections only.

Geophysical Investigations Maps are on topographic or planimetric bases at various scales; they show results of surveys using geophysical techniques, such as gravity, magnetic, seismic, or radioactivity, which reflect subsurface structures that are of economic or geologic significance. Many maps include correlations with the geology.

Miscellaneous Investigations Series Maps are on planimetric or topographic bases of regular and irregular areas at various scales; they present a wide variety of format and subject matter. The series also includes 7.5-minute quadrangle photogeologic maps on planimetric bases that show geology as interpreted from aerial photographs. Series also includes maps of Mars and the Moon.
Coal Investigations Maps are geologic maps on topographic or planimetric bases at various scales showing bedrock or surficial geology, stratigraphy, and structural relations in certain coalresource areas.

Oil and Gas Investigations Charts show stratigraphic information for certain oil and gas fields and other areas having petroleum potential.

Miscellaneous Field Studies Maps are multicolor or blackand-white maps on topographic or planimetric bases for quadrangle or irregular areas at various scales. Pre-1971 maps show bedrock geology in relation to specific mining or mineral-deposit problems; post-1971 maps are primarily black-and-white maps on various subjects such as environmental studies or wilderness mineral investigations.

Hydrologic Investigations Atlases are multicolored or blackand-white maps on topographic or planimetric bases presenting a wide range of geohydrologic data of both regular and irregular areas; principal scale is $1: 24,000$, and regional studies are at $1: 250,000$ scale or smaller.

\section{Catalogs}

Permanent catalogs, as well as some others, giving comprehensive listings of U.S. Geological Survey publications are available under the conditions indicated below from the U.S. Geological Survey, Information Services, Box 25286, Federal Center, Denver, CO 80225. (See latest Price and Availability List.)

"Publications of the Geological Survey, 1879-1961" may be purchased by mail and over the counter in paperback book form and as a set of microfiche.

"Publications of the Geological Survey, 1962-1970" may be purchased by mail and over the counter in paperback book form and as a set of microfiche.

"Publications of the U.S. Geological Survey, 1971-1981" may be purchased by mail and over the counter in paperback book form (two volumes, publications listing and index) and as a set of microfiche.

Supplements for $1982,1983,1984,1985,1986$, and for subsequent years since the last permanent catalog may be purchased by mail and over the counter in paperback book form.

State catalogs, "List of U.S. Geological Survey Geologic and Water-Supply Reports and Maps For (State)," may be purchased by mail and over the counter in paperback booklet form only.

"Price and Availability List of U.S. Geological Survey Publications," issued annually, is available free of charge in paperback booklet form only.

Selected copies of a monthly catalog "New Publications of the U.S. Geological Survey" are available free of charge by mail or may be obtained over the counter in paperback booklet form only. Those wishing a free subscription to the monthly catalog "New Publications of the U.S. Geological Survey" should write to the U.S. Geological Survey, 582 National Center, Reston, VA 20192.

Note-Prices of Government publications listed in older catalogs, announcements, and publications may be incorrect. Therefore, the prices charged may differ from the prices in catalogs, announcements, and publications. 